\title{
INTRODUÇÃO
}

O Rio Grande do Sul não difere dos outros estados do Brasil no que se refere às beligerâncias inscritas nos debates sobre a pesca. Ímpar é a capa “consensual” com que tentam encobrir os conflitos e torná-los pano de fundo, em nome de um viés científico que se acredita inquestionável, incomparável, incontornável. Na verdade, o que se esconde sob esta aparente harmonia e satisfação é também uma profunda falta de compreensão por parte das instituições (inclusive a academia) do que é a pesca. Fundamentados em pesquisas científicas sobre a biologia das espécies, atestam entender o comportamento dos homens para dizer-lhes como devem agir no seu cotidiano. Só muito recentemente, a partir do final dos anos 90, é que alguns trabalhos científicos têm levado ao cerne das instituições questionamentos ao status quo do ideário biologizante da ciência local. A impressão que se tinha é que objetivamente a ciência invariavelmente produziria apenas um resultado acerca do assunto. Agora emergem conflitos no âmago das instituições em função de algumas lacunas preenchidas e histórias reescritas mostrando que o "consenso" é resultado de um discurso falacioso ${ }^{1}$ sobre a pesca, os pescadores e o seu conhecimento tradicional através do qual produzem e se reproduzem. Dentro deste contexto de diferentes concepções científicas, essa dissertação se coloca neste último grupo já que tem como premissa a existência de um saber tradicional nas comunidades pesqueiras artesanais e como objetivo descrever o território de uma comunidade de pesca, a Coréia (Ilha dos Marinheiros - RS), através de uma perspectiva etnooceanográfica.

A opção pelo estudo etnooceanográfico agrega-se a um segmento de autores da etnociência, como Ruddle (2000) e Diegues (2004), que considera entre as áreas prioritárias no estudo do conhecimento tradicional as características físicas do hábitat aquático e o padrão migratório das espécies. Neste trabalho, o padrão migratório das espécies será tratado na sua relação com a hidrodinâmica estuarina.

O território aqui investigado se desdobra na área estuarina, de pesca propriamente dita, e "em terra", onde também se realizam atividades relacionadas à pesca. No entanto, é, sobretudo, dentro de uma área restrita do estuário que os nativos

\footnotetext{
${ }^{1}$ Uma análise do discurso de cientistas e políticos locais é tema de um artigo em preparação.
} 
coreanos saem para a "mareada" : o Saco do Arraial. O Saco do Arraial é uma das enseadas rasas da Lagoa dos Patos, a maior da zona estuarina, considerado pelas cientistas como uma área de "criadouro" de pescado e chamado pelos nativos de "nosso mar".

A literatura científica oceanográfica aponta diferenças quanto a aspectos hidrodinâmicos e ictiofaunísticos entre as zonas rasas (embaiamentos) e o corpo principal estuarino, incluindo a "zona de canal". O mesmo se sucede em estudos sobre a territorialidade dos pescadores artesanais: há diferenças das técnicas de pesca utilizadas entre aqueles que pescam em zonas rasas e no corpo estuarino principal, como pode ser visto em Almudi et al (2004). Se, no entanto, for comparado os resultados desta dissertação com a literatura etnocientífica gaúcha, sobretudo com as pesquisas realizadas em comunidades de pesca que atuam no corpo estuarino principal, será visto que as diferenças estão muito além das técnicas de pesca: o corpo de conhecimento tradicional e o calendário tradicional são bem distintos.

Para atingir tais objetivos, entende-se que o conhecimento do pescador coreano deve ser analisado e contextualizado não apenas no seu espaço, mas também no seu tempo. Assim, dá-se dinâmica ao território coreano, as águas da Coréia, segundo a lógica da pesca naquele lugar. Como a noção de lugar é central aos conceitos analíticos de "teoria local" de "conhecimento local" (GEERTZ, 1983) e de cultura (SAHLINS, 1979), define-se a escala de trabalho para situar a escala de análise, a comunidade da Coréia, onde há um "lócus" de partilha cotidiana das atividades pesqueiras e, por conseguinte, do conhecimento.

Os pescadores artesanais e os pescadores lavradores da Coréia se reproduzem através dos testemunhos históricos de seus antepassados. Portanto, o espaço e o tempo são diversos aos da modernidade. Espaço e tempo são vividos e apropriados sob a bitola da memória coletiva que existem, como diz Halbwachts (2006), sobretudo nas tradições.

Por isso, nosso ponta-pé inicial é dado pela sociologia de Maurice Halbwatchs e pela filosofia de Bérgson em que a intersecção entre espaço (imagem da estabilidade) e tempo (imagem da mudança), fundamentos da memória, permite alcançar a adaptação

\footnotetext{
2 "mareada" é a atividade de pesca no "mar". Para os pescadores de Barra da Lagoa, segundo Cunha (1988), para a palavra "mareada" há dois sentidos: o que envolve o movimento da maré com a passagem dos peixes e a ação do pescador sobre o peixe e o acaso.
} 
do ser no mundo ${ }^{3}$. Neste sentido, pode-se dizer que a intersecção entre espaço e tempo são pré-concepções para se pensar a (hidro)dinâmica da natureza já que os valores que eles encarnam constituem apenas uma das respostas possíveis. O tempo e o espaço para o exercício profissional são apropriados a partir da memória-hábito quando tempo e espaço passam a ser representados, conhecidos e tomados por e para um campo de ação, o campo de ação da pesca.

A base de qualquer representação é o conhecimento (RAFFESTIN, 1993). Nas sociedades marítimas de pesca o conhecimento é pautado em tradições pesqueiras e ligado à (hidro)dinâmica natural do seu mundo de exercício profissional, neste caso, em especial, um embaiamento do estuário da Lagoa dos Patos, o Saco do Arraial. Para a descrição deste conhecimento, utiliza-se do conceito de Conhecimento Ecológico Tradicional (CET) de Berkes (1999), pois abarca o aporte teórico advindo da memória coletiva na medida em que permite incorporar como um dos "processos adaptativos" no estudo de ecossistemas sob a lógica tradicional a intersecção entre espaço e tempo. Neste sentido, na adaptação do ser no mundo, o tempo é marcado por eventos materiais grávidos de significados, os "sinais de memória", irrompendo na perspectiva, adotada nesta dissertação, de um tempo conhecido e usado no cotidiano pesqueiro, fundamentando tomadas de decisão e ações.

Neste momento, deve-se ser mais enfático: toda a base teórica advindo da memória nos serve apenas para suscitar a intersecção do espaço com o tempo, pois é a partir da apropriação (conhecimento) do espaço e do tempo nesta intersecção é que se dá a construção territorial, a territorialidade e as tomadas de decisão. Portanto, o referencial teórico que dialoga diretamente com os dados será feito a partir do conhecimento tradicional do espaço e do tempo.

Para embasar a discussão de território uma consideração importante é feita quanto à escala. No mundo da pesca não apenas o território do grupo de pesca (território grupal) é analisado, mas também as microáreas de abundância ('pesqueiros').

$\mathrm{Na}$ análise do território grupal, o conceito de Bernard Nietschmann (1989), cunhado para um estudo que se poderia considerar de perspectiva etnooceanográfica, vai ao encontro dos fundamentos trazidos pela memória coletiva já que o território

\footnotetext{
${ }^{3}$ Acreditamos que a intersecção do tempo no espaço para a adaptação do ser no mundo seja um ponto em comum entre os teóricos da memória Halbwachs e Bérgson, ainda que o corpo geral de suas contribuições científicas sejam consideradas antagônicas, segundo os estudiosos da memória.
} 
como conhecimento também incorpora a noção relacional de uma sociedade tradicional com a dinâmica natural do mundo. Portanto, imbuído, além de espaço, da sua "quarta dimensão": o tempo. Ademais, possibilita que, além do espaço físico, o recurso também seja entendido como um "espaço" conhecido.

A partir desta concepção de território entende-se que um conjunto de relações sociais de cooperação e de exclusão (territorialidade) e tomadas de decisões se fundam a partir do conhecimento dos processos no e do espaço marítimo apropriado.

Já a unidade básica de apropriação do espaço estuarino (os 'pesqueiros'), cunhado por Cordell (1974), que, no caso da Coréia, pode ser feita pela embarcação com toda a tripulação ou até por um indivíduo, permite a análise da construção territorial, das relações de cooperação e exclusão (territorialidade) e das tomadas de decisão intracomunitárias também com bases no conhecimento tradicional.

A dinâmica e a delimitação do território do grupo são dadas pela movimentação dos pescadores na apropriação de pesqueiros. Deste fundamento, alcança-se entendimento como conflitos territoriais as relações com diferentes comunidades pesqueiras artesanais e a pesca industrial que exploram áreas de pesca distantes, mas exploram os mesmos recursos pesqueiros. Alterações no padrão natural do ciclo de vida conhecido destes recursos, em função das pescarias em outros territórios de pesca, trazem reflexos na organização territorial coreana ainda que separados por longas distâncias.

A partir dessa perspectiva adotada, em que o território é dotado de dinâmica através da intersecção do espaço com o tempo sob a lógica de uma tradição pesqueira, traz-se alguns subsídios para:

1 - o diálogo entre o conhecimento científico e o conhecimento tradicional sobre a hidrodinâmica de zonas rasas (berçários);

2 - o manejo de zonas rasas (berçário) do estuário da Lagoa dos Patos;

3 - base comparativa entre comunidades de pesca de zonas profundas (corpo principal do estuário e oceano) e comunidades de pesca de zonas de rasas (berçário) do estuário da Lagoa dos Patos. 
Para cumprir a construção teórica, o diálogo entre o corpo teórico e os dados de campo e as considerações finais e, assim, atingir os objetivos desta pesquisa, a dissertação está estruturada em 5 capítulos.

O primeiro capítulo lança as bases teóricas para a análise do espaço, tempo e conhecimento tradicional como constituintes do território de uma comunidade pesqueira. O conceito de memória fundamenta a intersecção do espaço com o tempo que conhecido pelo homem, e, portanto, territorializado, embasa sua relação dinâmica com seu mundo.

O segundo capítulo aborda a inserção em campo e os métodos e técnicas que nortearam a pesquisa a fim de se atingir os objetivos da dissertação.

O capítulo seguinte apresenta uma descrição da área de estudo: a Lagoa dos Patos e a Ilha dos Marinheiros. Além disso, faz-se um histórico da pesca na Lagoa dos Patos e uma necessária reinterpretação da literatura acerca da cultura na Ilha dos Marinheiros, pois comumente as bases científicas sobre a Ilha visam atender interesses econômicos evidenciando na história local apenas elementos de apreciação turística.

No quarto capítulo inicia-se a análise dos dados segundo o referencial teórico adotado. Primeiramente é descrito, delimitado e nomeado o espaço territorial pesqueiro coreano através das categorias nativas. Dada estas convenções nativas, é construída a ordenação e a interação das forçantes naturais na hidrodinâmica do "nosso mar". A hidrodinâmica do "nosso mar" é completada, no entanto, quando o tempo é materializado no espaço e movimento e significado ao movimento espacial é dado na etnocronologia estuarina através dos "sinais de memória". A etnocronologia estuarina, por sua vez, é subsídio a etnonocronologia da pesca: no primeiro são gerados os contextos estuarinos a partir dos quais se dá, no segundo, a construção das decisões e ações na pesca. Finalmente, decido "quando", "como" e "onde" pescar, é descrito um conjunto de relações sociais fundadas na instituição da posse de "pedaços de mar", os "pesqueiros".

No último capítulo, por fim, faz-se algumas considerações finais e conclusões sobre o conhecimento tradicional do espaço e do tempo e o território coreano que é construído por este conhecimento. 


\section{METODOLOGIA DE PESQUISA}

A comunidade estudada, a Coréia, localiza-se na porção norte da Ilha dos Marinheiros, portanto no ponto mais distante em relação à cidade do Rio Grande, onde pescadores artesanais e pescadores-lavradores desenvolvem suas atividades pesqueiras em um dos embaiamentos da Lagoa dos Patos, o Saco do Arraial (Figura 1). No sentido de um estudo etnocientífico, o escopo de compreender o homem ilhéu-Coreano como sendo parte integrante de uma região do ecossistema estuarino (e vice-versa) passa pelo mapeamento do que Tullio Persio Maranhão (1975), no seu estudo em Icaraí (CE), chama de "esquemas cognitivos coletivamente partilhados dentro de um quadro de referência cultural" (: 06) ${ }^{4}$. Neste sentido, a partir do quadro de referência cultural de uma comunidade de pescadores artesanais e pescadores-lavradores de um "baixio" estuarino pretende-se fornecer subsídios a propostas de manejo autênticas.

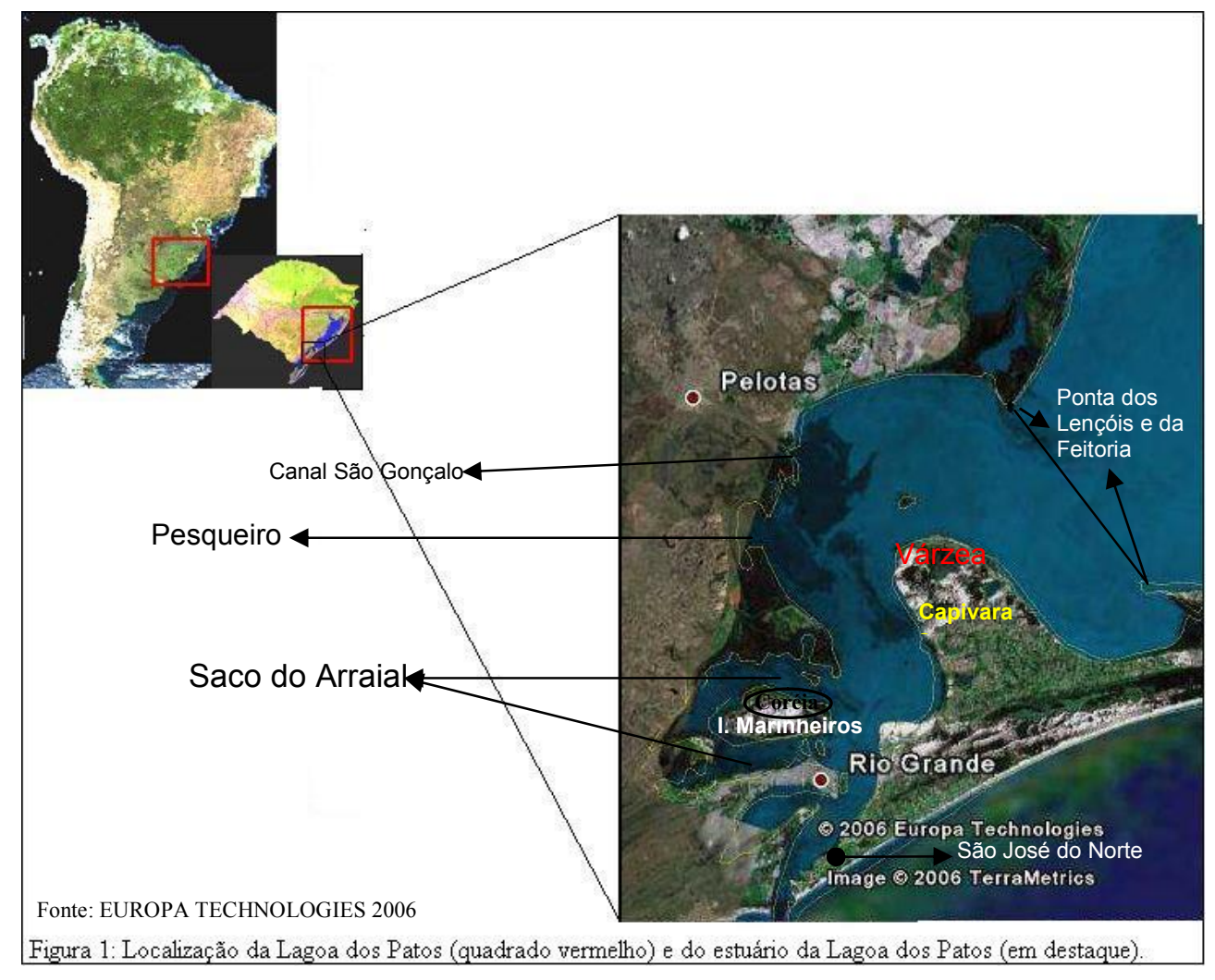

O desembarque na Coréia para o início dos trabalhos de campo se dá no primeiro dia de fevereiro de 2007 e se estende até 29 de novembro do mesmo ano, com "inserção total”, ou seja, o pesquisador acaba residindo junto aos ilhéus da comunidade

\footnotetext{
${ }^{4}$ Neste sentido, segundo Rappaport (1984: 261) "a forma pela qual os homens participam de qualquer ecossistema depende não só da estrutura e composição do ecossistema, mas também da bagagem cultural dos que entram nele".
} 
em estudo. No entanto, há dois momentos de ausência, de 06/07 a 10/08 e de 21/09 a 26/11, o que totaliza 6 meses e 20 dias de trabalho de campo.

A inserção em campo se dá de forma absolutamente cuidadosa, sobretudo, após as primeiras conversas que revelam algo que os nativos coreanos não fazem questão alguma de dissimular: a desconfiança em relação aos pesquisadores. Figurada em histórias que, seja emergência de mitos ou não ${ }^{5}$, se referem a atos de desrespeito de pesquisadores em relação a membros da comunidade, o que resulta em questionamentos da utilidade dos trabalhos de pesquisa e em recusas às entrevistas e de ter petrechos de pesca fotografados. Assim, pondera-se o respeito como base indispensável à realização da pesquisa estabelecendo o tom necessário a um relacionamento compartilhado entre iguais (POSEY, 1986; MARQUES, 1991). A abertura para a "inversão de papéis" e a permanência entre os nativos (PIETRAFESA DE GODOI, 1999) também contribuíram para "co-elaborar" o tom entre iguais e, assim, dissipar o clima hostil.

Durante a tessitura do modelo cognitivo utiliza-se um procedimento eclético que funciona, concomitante, como método de coleta e análise e como teste experimental para a obtenção de uma metodologia adequada (MARQUES, 1991).

Com a inserção em campo, a observação participante junto a um caderno ou diário de campo, conforme propõem Guimarães (1990) e Viertler (2002), foram utilizadas como técnicas de coleta de dados. A técnica de observação participante empregada satisfaz a modalidade "observador participante ativo" de acordo com Schwartz e Schwartz (1955). A participação entre os nativos é condição necessária para um contato em que a razão e a emoção se completem e a observação forneça a medida de todas as coisas (PIETRAFESA DE GODOI, 1999). Esta técnica proporcionou informações circunstanciais verbais ${ }^{6}$ e não-verbais ${ }^{7}$ dos pescadores, ambas consideradas manifestações de profusos significados culturais e transmissores de conhecimento, que junto às observações naturalísticas foram registradas de forma interpretativa em um diário de campo (MARQUES, 1991). A observação participante permeia todo o trabalho de campo. No entanto, associada às entrevistas não-estruturadas precede todas as fases de entrevistas parcialmente estruturadas, pois ambas são geradoras de dados, ou

\footnotetext{
${ }^{5}$ Em Marques (1991: 40) também foi percebido desconfianças entre pescadores e pesquisadores, mas que se manifesta, segundo o autor, "inclusive através da emergência de mitos".

${ }^{6}$ No uso da fala, há uma seleção pelos "informantes" de assertivas em detrimento de outras, num contexto sócio-linguístico particular, o que delineia as fronteiras de uma categoria num mapa cognitivo cultural (FRAKE, 1962).

${ }^{7}$ Reverbero Jacques Laberge (1988: 45): os pescadores são os "profissionais do silêncio".
} 
seja, "a partir de cujas respostas procedia-se a uma seleção dentre as palavras e/ou expressões empregadas pelo informante, a fim de gerar novas perguntas que permitissem obter dados novos ou complementares" (Op. Cit: 39; PIETRAFESA DE GODOI, 1999). Portanto, as entrevistas não-estruturadas foram se fechando à medida que a decodificação das atividades comunitárias permitiu caminhar as entrevistas parcialmente estruturadas, conforme recomenda Viertler (2002), e à indexação do caderno de campo por tema (PIETRAFESA DE GODOI, 1999).

As entrevistas formais sempre foram precedidas por explanação sobre o trabalho e de pedidos de permissão para gravá-las. A cada fase de entrevista, descritas mais adiante, pediu-se autorização dos pesquisados, o que caracteriza o trabalho de campo, segundo Almassy Jr. et al. (2002), como um processo ininterrupto de negociações. A transcrição das gravações foi feita verbatim, ou seja, houve tradução direta e apenas as declarações de importância crucial foram transcritas (GUIMARÃES, 1980).

No total, as entrevistas parcialmente estruturadas foram realizadas com 21 pessoas, tendo a Coréia 212 habitantes (portanto, amostragem de aproximadamente 10\% de toda a comunidade estudada). Os entrevistados foram apontados pelos próprios membros da comunidade como "especialistas" empregando-se o método da "bola de neve" ('snow-ball') até se atingir altos níveis de consistência informativa, quando se considera o tamanho amostral suficiente (BAILEY, 1982). Dentre os entrevistados formalmente têm-se os que se aposentaram na atividade pesqueira e os pescadores da ativa com no mínimo 25 anos de experiência na pesca e no mínimo 36 anos de idade, o que não quer dizer que informalmente não se tenha conversado com pescadores menos experientes. Merece destaque a suma importância que a conversa com pescadores mais jovens teve, mesmo que informalmente, na abertura de novas etapas informativas em momentos em que a pesquisa dava uma falsa impressão de consistência informativa possibilitando a reestruturação e expansão da rede conexiva até então construída. Assim, pode-se dizer que também foi utilizada a técnica da "informação reunida em partículas" de Evans Pritchard (2007: 20), já que cada nativo encontrado foi considerado uma fonte de conhecimento.

As entrevistas parcialmente estruturadas foram divididas em duas fases. A primeira fase consiste nas perguntas principais relacionadas aos temas deste trabalho: 
1) Conhecimento tradicional: "Quando a água 'corre' de enchente e de vazante 'aqui dentro'?”.

2) Território ('pesqueiros’ e território grupal ou comunitário): “Onde o $\mathrm{Sr}$. pesca tal recurso? Quando? Com quais 'petrechos'?". Dispõe-se de perguntas que contemplem os principais elementos do conceito de território: "onde", "quando", "como", "o quê". As histórias e relatos associados às respectivas respostas foram considerados e exaustivamente discutidos com cada um dos entrevistados. Houve também o aproveitamento de conceitos advindos da entrevista sobre o conhecimento tradicional.

As respostas a estas perguntas geram informações que se desdobram, subsequentemente, na segunda fase de entrevistas parcialmente estruturadas. O objetivo da segunda fase de entrevistas parcialmente estruturadas é esclarecer e desenvolver conteúdos explícitos na primeira resposta e em fatos e conversas do cotidiano (PIETRAFESA DE GODOI, 1999), inclusive fatos recorrentes na "técnica de turnê".

A “Técnica de turnê" de Spradley e McCurdy (1972) é empregada perfazendo mais de 40 excursões guiadas pelos pescadores. Em relação a esta técnica, vale pontuar: 1 - em nenhuma delas o pesquisador se integrou ao trabalho do pescador ${ }^{8} ; 2$ - recorreuse especialmente à observação participante durante as excursões.

Evidencia-se a particularidade de uma excursão cujo objetivo é estritamente "per-fazer" o território coreano representado inúmeras vezes na areia (desenhos) e uma vez na cartolina (mapa). A areia e a cartolina foram utilizadas para a representação gráfica das suas narrativas (VIERTLER, 2002), dos pontos de marcação da memória do grupo ('campos de memória') (PIETRAFESA DE GODOI, 1999), e do que lhes foi pedido: "Me mostre o local onde os coreanos pescam". A representação gráfica resultante é o mapa cognitivo (PIETRAFESA DE GODOI, 1999; VIERTLER, 2002) do seu território (Figura 2).

\footnotetext{
8 A "vivência" do território e da territorialidade coreana se dá simultaneamente a da prática do conhecimento tradicional, ou seja, estas "vivências" se dão nas mesmas excursões já que o objetivo foi vislumbrar o conhecimento tradicional dos pescadores em suas práticas cotidianas.
} 


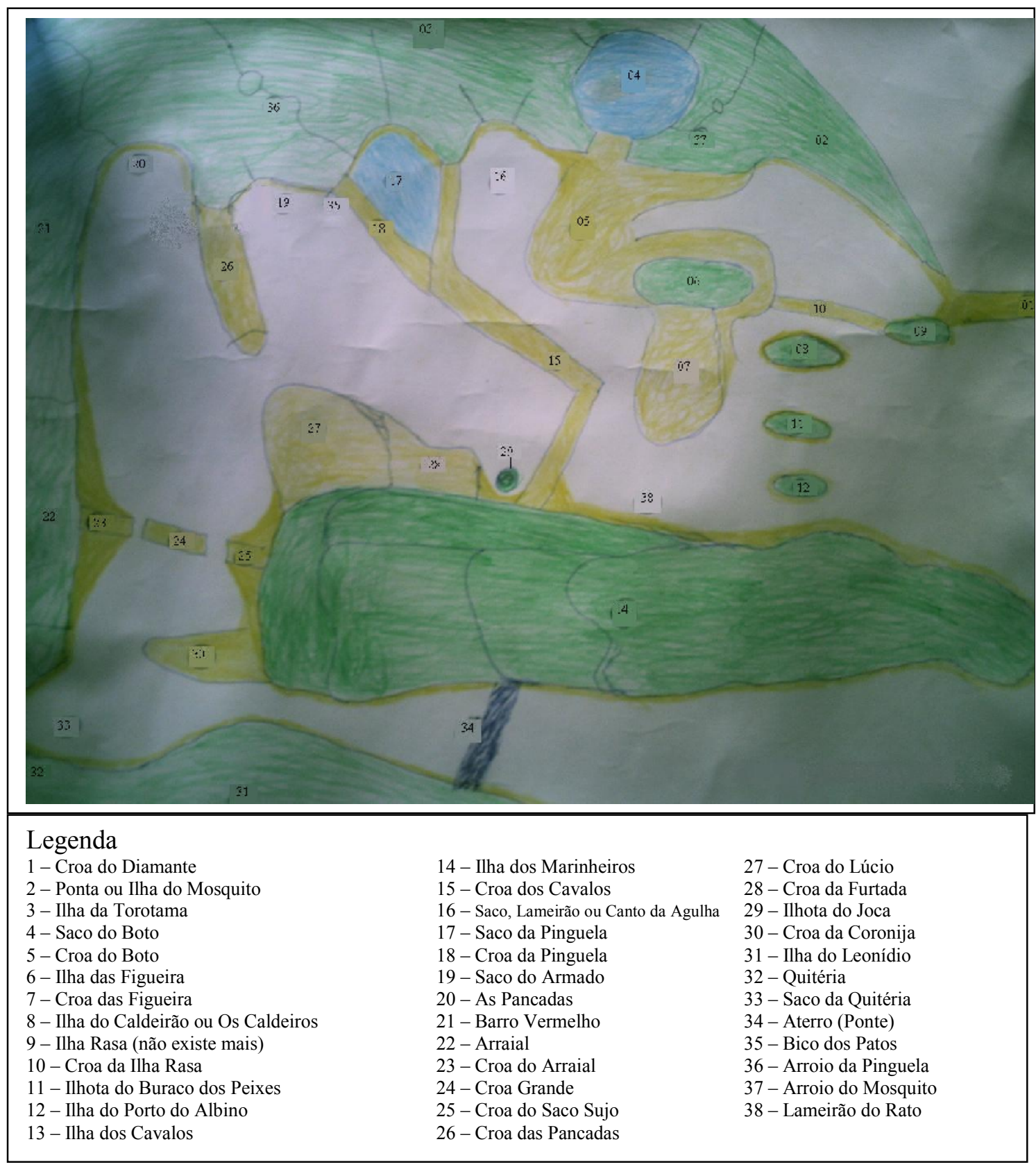

Figura 2: Mapa cognitivo do "nosso mar".

Tais técnicas declaram opção pela abordagem êmica ${ }^{9}$ das categorias nativas. A análise dos dados consistiu na escolha dentre estas estruturas de significação das importantes bases sociais (GEERTZ, 1989) no relacionamento ilhéus/coreanos com o ambiente estuarino no artifício da pesca.

\footnotetext{
${ }^{9}$ O significado da palavra "êmica", oriundo de fonêmico (entonação), passou a descrição de um sistema comportamental de uma dada cultura nos seus próprios termos (CAMPOS, 2002), ou seja, são as categorias cognitivas e linguísticas da comunidade tradicional (POSEY, 2001). Portanto, para estudar o conhecimento das populações tradicionais, que é transmitido oralmente, sobre os processos naturais e sua lógica subjacente, a etnociência parte da linguística, pois este conhecimento só pode ser interpretado dentro do contexto da cultura em que ele é gerado (MARANHÃO, 1975; DIEGUES, 2000).
} 


\section{REFERENCIAL TEÓRICO}

\subsection{Memória}

"O triplo problema do tempo, do espaço e do homem constitui a matéria memorável". Le Goff (2003: 429)

No final do século XVII e primeira metade do XVIII, o mundo ocidental, a propósito da ciência, da literatura e da arte, polemiza a respeito do antigo/moderno com tendência à reviravolta da valorização do passado. O passado torna-se sinônimo de superado e o moderno, de progressista. Até fins do século XVIII as sociedades ocidentais ainda valorizam o passado (LE GOFF, 2003), mas a partir daí, séc. XIX e $\mathrm{XX}$, da construção da oposição do antigo/moderno há o triunfo da idéia de progresso e a destruição "com violência" destas experiências ligadas à tradição e à memória dos seus antepassados (BRANDÃO, 1998; LE GOFF, 2003).

Neste sentido, a modernidade, instalada com o advento da Revolução Industrial, privaria o homem de uma faculdade que lhe parecia inalienável, a de intercambiar experiências: o adestramento do operário à máquina abstrai qualquer experiência transmissível às gerações sucessivas, o que leva a um abalo da tradição (BENJAMIN, 1985; 1989). O relato oral, que até então constituíra a maior fonte de difusão e conservação do saber (QUEIROZ, 1988), deixou de ser familiar à humanidade e passa a ser decisiva apenas no trabalho artesanal (BENJAMIN, 1985; 1989; BRANDÃO, 1998).

Já na Inglaterra do século XVIII, a modernidade abre um "hiato profundo entre cultura patrícia e da plebe" fazendo que a pequena tradição plebéia fique cada vez mais com "hábitos estranhos e ritos" para os das camadas sociais "superiores" (THOMPSON, 1998:13). A preservação das tradições é um legado que permanece até a contemporaneidade, o que mantém a dialética entre mundo moderno urbano-industrial e o mundo tradicional.

Mas o que seria esta memória, experiência e tradição que foram perdidos através da história? 
“Os homens morrem porque não são capazes de ligar o começo ao fim”, diz o mito órfico ${ }^{10}$. Ecléa Bosi em seu livro "Memória e sociedade: lembrança de velhos" observa que memini e moneo (da raiz mn) 'eu me lembro' e 'eu advirto', respectivamente, são parentes próximos. Neste sentido, Pietrafesa de Godoi (1999) ousa dizer que a função social da memória no sentido de lembrar e advertir ${ }^{11}$ é unir o começo ao fim, ligando o que foi e o porvir. Neste sentido, a memória não seria um patrimônio definitivamente construído, estático, morto; ao contrário ela é viva porque nunca está acabada.

Consoante, Maurice Halbwachs em seu livro "A memória coletiva", define a memória como um trabalho de reconhecimento e reconstrução que atualiza os "quadros sociais" nos quais as lembranças podem permanecer e, então, articular-se entre si. A memória é sempre construída em grupo (memória coletiva), mas também um trabalho do sujeito (memória individual). Para a articulação entre as duas memórias, no entanto, necessita-se de muitos pontos de contato entre uma e outra para que as lembranças evocadas sejam reconstruídas sobre uma base comum.

Haveria, portanto, dois tipos de memória que antes da secularização moderna eram amarradas entre si (BOSI, 2004). Isto porque a memória coletiva vive, sobretudo, na tradição (SHIMIDT e MAHFOUD, 1993, HALBWACHS, 2006), ou seja, adotando a perspectiva de Walter Benjamin o testemunho histórico e a oralidade, ambos abalados pela era da reprodutibilidade técnica, são elementos que dão a experiência individual e coletiva o seu peso tradicional na medida que através de um elemento dito um testemunho histórico autêntico é entregue, passado de geração a geração ${ }^{12}$ (BENJAMIN, 1985; GAGNEBIN, 2004). Neste sentido, as tradições são os produtos de gerações de inteligentes reflexões testadas no rigoroso laboratório da sobrevivência e, consequentemente, duradouras adaptações para lugares específicos (BERKES, 1999).

Segundo Bérgson, em seu livro "Matéria e memória", por vezes a memória coletiva é denominada memória-hábito. Neste caso, uma memória mecânica demanda lembranças "úteis" "na medida em que a vida psicológica entra na bitola dos hábitos, e

\footnotetext{
10 Culto religioso-filosófico cuja característica principal é a crença na imortalidade (HOUAISS e VILLEN, 2004).

${ }^{11} \mathrm{O}$ termo advertir em seu sentido etimológico guarda o sentido de, entre outros significados, fazer lembrar (HOUAISS e VILLEN, 2004).

$12 \mathrm{O}$ termo tradição no seu sentido etimológico deriva do latim traditio. O verbo é tradire significa precipuamente entregar (HOUAISS e VILLEN, 2004). Alguns estudiosos, no entanto, referem-se à relação do verbo tradire não só com o conhecimento oral, mas também com o escrito (LE GOFF, 2003).
} 
move-se para a ação e para os conhecimentos úteis ao trabalho social" (BOSI, 2004: 3839). Estes conhecimentos práticos e pautados nas tradições (BOSI, 2004; HALBWACHS, 2006) são os que as sociedades "selvagens" mais se interessam (LE GOFF, 2003).

Dentro de um conjunto de acontecimentos e vivências destacáveis o que se evoca em lembranças são seleções daquilo que pertence a um quadro de preocupações e interesses atuais e a uma aproximação de percepções determinadas pela ordem (posição no espaço) de determinados objetos sensíveis (HALBWACHS, 2006). Neste sentido, as lembranças facultariam a escolha da alternativa mais consoante à ação nascente, o que viabiliza a materialização das lembranças, dando mais consistência aos saberes e corpo ao trabalho da memória (SHIMIDT e MAHFOUD, 1993).

Eis o modo pelo qual a intersecção entre tempo e espaço se presentifica e logra alcançar a adaptação do ser no mundo, segundo Bérgson (1990) (PAIVA, 2005). O tempo oferece continuamente a imagem da mudança enquanto o espaço a da permanência e estabilidade. As dimensões do espaço e do tempo são, desse modo, os fundamentos da memória (HALBWACHS, 2006) e, portanto, pré-concepções para se pensar social e individualmente a natureza e sua própria sociedade (MALDONADO, 1993).

Em 2.2 será visto como se constrói o conhecimento através do qual as tradições se apropriam da intersecção do espaço e do tempo e, nos itens subsequentes, como ocorre a apropriação do espaço e do tempo e as consequências desta apropriação.

\subsection{Conhecimento tradicional}

Os seres humanos são partes do ecossistema e não algo à parte (FOLKE et al, 2004). Na co-evolução entre homem e natureza, as surpresas trazidas pela dinâmica ambiental são regras e não exceções (GUNDERSON, 1999). Entender o processo ecossistêmico parece ser uma via da co-evolução sócio-ecológica, o que envolve uma acumulação de conhecimento individual e coletivo sobre o ecossistema compreendido na "memória social” (OLSSON e FOLKE, 2004). 
No cerne das relações materiais do homem com a natureza emerge uma parte ideal, não material, onde se exercem e se entrelaçam as três funções do conhecimento: representar, organizar e legitimar as relações dos homens entre si e deles com a natureza (DIEGUES, 2004a).

Existem, no entanto, segundo Levi Strauss (1976), dois modos de pensamento científico, um muito próximo da intuição sensível e outro mais distanciado. O primeiro seria o conhecimento prático, a "ciência do concreto", dos povos "primitivos" e o segundo, a ciência moderna.

O conhecimento mais próximo da percepção sensível é um saber transgeracional prático, dinâmico ('aberto a mudanças'), local e mitificado em quase todos os grupos geograficamente distribuídos e estudados na África, América, Austrália e Nova Guiné (BERKES, 1999; 2003).

A necessidade de transmitir esse conhecimento ao longo das gerações é a medida de confiança nele depositado (ALLUT, 2000). Por seu caráter transgeracional, vários estudiosos destes grupos (JOHANNES, 1977; 1978; POSEY, 1986; ALLUT, 2000; DIEGUES, 2000; MARQUES, 2001; SEIXAS e BERKES, 2003) titulam estes grupos de populações tradicionais e a "ciência" destes povos de conhecimento tradicional. As pesquisas com enfoque no conhecimento tradicional destes grupos fundam a etnociência ${ }^{13}$ (DIEGUES, 2000).

Ainda no que se refere ao aspecto transgeracional, vale destacar que apesar da acumulação do conhecimento tradicional sobrevir coletivamente, ela também se dá por meio do trabalho do sujeito resultando numa distribuição não-homogênea do conhecimento: instala-se uma "rede de informações interligadas" dominada por certos indivíduos de uma comunidade ${ }^{14}$ (POSEY e ELISABETSKY, 1991). Allut (2000) e Diegues (2004) ressaltam que estes indivíduos que concentram o conhecimento ('especialistas') em uma comunidade tradicional geralmente são os mais velhos e experientes.

A capacidade de proporcionar certa ordem ao mundo e de permitir uma ação ordenada num processo de adaptação a um mundo em contínua mudança é a medida de

\footnotetext{
${ }^{13}$ Segundo Diegues (2000), a etnociência é um campo relativamente novo da ciência, e por isso ainda está construindo seu método e sua teoria, que tenta descobrir a lógica subjacente do conhecimento tradicional sobre o mundo natural partindo da linguística.

${ }^{14}$ Dentro da comunidade etnocientífica, o conhecimento tradicional é veiculado e apropriado fora da dinâmica interna das comunidades tradicionais através de estudos e publicações (MOREIRA, 2003).
} 
êxito do conhecimento tradicional. Este processo adaptativo contribui para a construção do conhecimento sobre uma base hierarquizada e seletiva, obtido, em grande parte, pelo aprendizado perceptivo. Neste sentido, além dos saberes dos antepassados, empregam uma atenta e hábil percepção sensorial que intervêm como receptores de informações presentes (ALLUT, 2000).

Em decorrência da função prática do conhecimento tradicional, ele deve ser contextualizado socialmente e espacialmente, pois os elementos do conhecimento tradicional e sua aplicação emergem e funcionam dentro de contextos sociais específicos (DIEGUES, 2000; RUDDLE, 2000). Assim, o conhecimento tradicional só pode ser interpretado dentro do contexto da cultura em que ele é gerado.

Os mitos locais são resultados de aprendizados sociais e evoluções culturais (ALLUT, 2000; SEIXAS e BERKES, 2003) que, em certos casos, favorecem a representação de relações ecológicas que pode estar mais próxima da realidade do que o conhecimento científico (GÓMEZ-POMPA e ANDRÉA KAUS, 2000).

Não é por acaso que muitos autores da etnociência atribuem a nossa herança de biodiversidade e a sua geração e manutenção, inclusive na contemporaneidade, em grande parte, às populações tradicionais (ALLUT, 2000; BERKES et al, 2000; GÓMEZ-POMPA E KAUS, 2000; SCHWARTZMANN, 2000; BARROS, 2003; DIEGUES, 2004a). Neste sentido, a biodiversidade está ligada à diversidade cultural (LEFF, 2001).

Dentro de uma perspectiva etnooceanográfica as características citadas acima são extremamente importantes que estejam no campo investigativo, sobretudo o caráter prático, adaptativo e local do conhecimento tradicional. Por isso, o conceito adotado é o de conhecimento ecológico tradicional de Berkes (1999: 8, tradução nossa): “...um cumulativo corpo de conhecimentos, práticas e crenças, evoluindo por processos adaptativos e propagados através das gerações por transmissão cultural, sobre relações de seres vivos (incluindo os humanos) uns com os outros e com seus ambientes" ${ }^{\text {"15 }}$.

No campo investigativo das etnociências, há uma grande diversidade de informações passíveis de estudos nas populações tradicionais. Aquelas referentes à classificação dos organismos em classes, a nomenclatura (princípios linguísticos para

15 “... definition of traditional ecological knowledge as a cumulative body of knowledge, practice, and belief, envolving by adaptative processes and handed down through generations by cultural transmission, about the relationship of living beings (including humans) with one another and with their environment." 
nomear as classes folk) e a identificação (relação entre os caracteres dos organismos e sua classificação) são consideradas por Lévi-Strauss (1976) como as áreas básicas do conhecimento tradicional.

Seixas e Berkes (2003), no entanto, apontam como principais lições do conhecimento ecológico tradicional a unidade e diversidade do sistema nativo, a importância do manejo dos recursos baseado na participação comunal e a ética da ecologia sagrada.

Já outros autores (CORDELL, 1989; RUDDLE, 2000; MARQUES, 2001; DIEGUES, 2004b) apontam áreas prioritárias mais específicas de acordo com a população tradicional de estudo. Para Ruddle (2000) e Diegues (2004b), as principais áreas e temas do conhecimento tradicional na pesca são as classificações de espécies aquáticas e de hábitat, comportamento dos peixes, taxonomias, padrões de reprodução e migração das espécies, cadeias alimentares, características físicas e geográficas do hábitat aquático, clima (nuvens, ventos, mudança do tempo), as artes de navegação e pesca e as relações com o mundo sobrenatural.

O estudo etnooceanográfico resulta na opção por este último segmento de autores da etnociência, pois será trabalhado a hidrodinâmica (inclui características físicas do hábitat aquático e clima) e o comportamento migratório das espécies pescadas segundo a hidrodinâmica.

Pontuadas as características e a natureza do conhecimento tradicional e as opções adotadas pela perspectiva etnooceanográfica, em 2.3 será tratado sobre as formas de apropriação do espaço por este conhecimento e as consequências que emergem desta apropriação.

\subsection{Memória Coletiva e Conhecimento tradicional do espaço/território}

Toda memória coletiva acontece num contexto espacial (WEIL, 1979; HALBWACHS, 2006). A memória de um grupo conserva suas lembranças no ambiente material que o circunda, no espaço que ocupa, num espaço conhecido, no "nosso espaço" (HALBWACHS, 2006). O local recebe as marcas do grupo e vice-versa, ou melhor, as ações do grupo também podem ser traduzidas em termos espaciais. Portanto, 
há tantas maneiras de representar o espaço quanto grupos tal como formas de se compor e agir sobre o solo (RAFFESTIN, 1993; HALBWACHS, 2006).

Quando há uma representação de um determinado espaço, ou seja, a partir do momento em que é definido, caracterizado, distinguido, classificado, delimitado e assim conhecido e praticado, ele é apropriado (CORDELL, 1989; RAFFESTIN, 1993). Ao se apropriar de um espaço, o grupo "territorializa” o espaço (RAFFESTIN, 1993).

Sob esse aspecto, pode-se dizer que território é conhecimento e domínio prático na medida em que viabiliza representações que cada grupo faz da instância natural que explora (CORDELL, 1983; MALDONADO, 1993). Neste sentido, para se descrever o território coreano dentro de uma perspectiva etnooceanográfica, opta-se pelo conceito do território como conhecimento:

\begin{abstract}
Os territórios marinhos não são apenas espaços marinhos delimitados, mas áreas nomeadas, conhecidas, usadas, reinvidicadas e, às vezes, defendidas. A familiaridade de um grupo social com uma área cria um território. Um território, terrestre ou marinho, é mais que simplesmente um espaço delimitado e recursos defendidos para o uso exclusivo de um grupo particular. Um território é um espaço cultural e social como também um espaço de recursos e de subsistência. O espaço marinho torna-se uma entidade porque um grupo social funda e reconhece o local, os padrões e a interação entre as coisas e os processos marinhos. O espaço marinho torna-se familiar à medida que se identifica e se dá significado aos aspectos físicos e bióticos. Lugares usados são lugares nomeados. As pessoas conceitualmente produzem o ambiente que elas usam, delimitam e defendem. (NIETSCHMANN, 1989: 60, tradução nossa) ${ }^{16}$.
\end{abstract}

Como o grupo estudado é uma comunidade pesqueira artesanal, procede primeiramente que as conceituações sobre a lógica e as práticas de apropriação do espaço referem-se ao mundo da pesca artesanal. Segundo Cordell (1989), os principais mecanismos de apropriação são três: o conhecimento tradicional, delimitação territorial e relações de exclusão e de cooperação.

Em segundo lugar, resulta que a escala de apropriação e de atuação no espaço constituem duas unidades: a "unidade físico-espacial" e, em menor escala, as "unidades básicas" de apropriação do espaço aquático.

\footnotetext{
16 "Sea territories are not just bounded sea space but áreas named, known, used, claimed and sometimes defended. A social group's familiarity with an area creates a territory. A territory, whether terrestrial or marine, is more than simply spatially delimited and defended resources for the exclusive use of a particular group. A territory is social and cultural space as much as it is resource or subsistence space. Sea space becomes an entity because a social group establishes and recognizes the location, pattern and interation of marine things and processes. Water space is made familiar by naming and giving meaning to physical and biotic aspects. Places used are places named. People conceptually produce the environment they use, delimit and defend".
} 
A primeira escala de apropriação é uma unidade físico-espacial ('lócus') onde se desenvolve o partilhar cotidiano de atividades que nucleia as relações sociais, exaltando suas carências ou excelências que atinge a todos (CUNHA, 1987, DURHAM, 2004). É a comunidade como lugar: "O lugar, a existência local dos fenômenos tanto no espaço físico como no espaço social é que lhes confere a essência, significado e transcendência. É localmente que nos situamos e é localmente que as coisas acontecem" (MALDONADO, 1993: 34). Este espaço de uso comum ${ }^{17}$ dos comunitários será chamado de território grupal ou comunitário.

A outra escala de apropriação constituem as unidades básicas de apropriação do espaço marítimo e/ou estuarino, ou seja, as microáreas de abundância de pescados que também são chamadas de "pesqueiros" por Cordell (1974; 1989), denominação adotada para esta dissertação, ou "pedras" por Maldonado (1993).

Neste sentido, na construção do território na Coréia há duas escalas de análise de território, o território do grupo e os pesqueiros, perspectivas adotadas por outros autores como Cordell (1989), Iwakiri e Mantjoro (1992) e Begossi (2004) ${ }^{18}$.

Portanto, apesar de ambos se construírem no sentido de controlar o acesso aos recursos através de relações sociais de exclusão e cooperação e da fundação de fronteiras, estão sujeitos às particularidades inerentes a escala de atuação (MALDONADO, 1988; CORDELL, 2001; BEGOSSI, 2004).

Nas diferentes formas de construção do território em populações tradicionais, o conhecimento dos recursos é base para as idéias/sistemas de acesso aos recursos e de tomadas de decisão no uso territorial (HAESBAERT, 2006). Para Cordell (1983), além dos recursos, o conhecimento de compartimentos ambientais também é fundamental para o acesso aos recursos. Isso quer dizer que é subjacente a um sistema de relações informais histórico e comunitário (CORDELL, 1983; 1989), chamado de territorialidade, que limita o acesso aos recursos através da posse coletiva ou dos

\footnotetext{
${ }^{17}$ Segundo Diegues e Moreira (2001), quanto ao direito de propriedade, uso e manejo sobre os recursos há quatro tipos de categorias: propriedade comunal (recursos manejados por uma comunidade de usuários), estatal (recursos manejados pelo estado), privada (manejo delegado a indivíduos ou a empresas) e de livre acesso (ausência de direitos de propriedade).

${ }^{18}$ Vale ressaltar que apesar de adotorem o território grupal e os "pesqueiros" como dois níveis diferentes de análise em suas pesquisas, os autores citados não analisaram apenas uma comunidade no território grupal, mas várias. Neste sentido, o território grupal foi constituído por várias comunidades de pesca.
} 
"pesqueiros"19, o conhecimento tradicional do território de pesca (BEGOSSI, 2004; 2006).

A delimitação de um território, seja um "pesqueiro" 20 ou grupal, com a formação de fronteiras, protege contra "forasteiros" por meio do segredo, da difusão de informações contraditórias e de fortes laços sociais no interior do território que dificultam a atuação daqueles que não tem uma intensa participação na comunidade (CORDELL, 1989). As fronteiras, também conhecidas como "zonas tampão" ou "bordas", são zonas entre comunidades ou entre dois ou mais pesqueiros, onde os direitos de posse e de uso são definidos frouxamente ou até não são definidos (CORDELL, 1983; 1989; BEGOSSI, 2000).

Como atitude de construtos sociais de apropriação do mar, o segredo não se refere apenas ao conhecimento ocultado com relação a um pesqueiro, mas também às melhores técnicas, os ventos indicados, as marés, etc (MALDONADO, 1993; RAMALHO, 2006).

Dentro de um conjunto de relações sociais de cooperação para a manutenção de pesqueiros, vale destacar duas: o respeito como uma referência cognitiva e, portanto, ordenadora do espaço, que liga a consciência comunitária coletiva ao reconhecimento e à legitimação (através das práticas) das regras tradicionais de uso territorial (MALDONADO, 1988); e a difusão de informações como uma forma de dividir os riscos causados pelas imprevisibilidades ambientais (CORDELL, 1983; 1989; 2001; RAMALHO, 2006).

Como uma das regras tradicionais no âmbito do respeito, destaca-se a reverência a espaços considerados sagrados (ou assombrados). Neste sentido, o espaço territorializado não é homogêneo, pois apresenta rupturas, espaços qualitativamente diferentes uns dos outros (ELÍADE, 1992).

Consequentemente, o sistema de posse marítima tem uma clara função de diminuir os conflitos e a competição, apesar da suscetibilidade da pesca aos conflitos, alocar e diminuir a pressão sobre os recursos, definir técnicas de pesca mais

\footnotetext{
${ }^{19}$ Um "pesqueiro" não necessariamente se refere à posse de um espaço marítimo ou estuarino por um indivíduo, mas também por um conjunto de indivíduos que costumam pescar juntos, ou seja, a microárea de abundância pode pertencer a um "bote", como bem colocou Maldonado (1993). Estes territórios "individuais" são equivalentes aos "pesqueiros", definidos logo adiante.

${ }^{20}$ Segundo Cordell (1983), a nomeação de um "pesqueiro" já é um indicador de instalação de fronteira.
} 
compatíveis com a realidade local segundo a lógica do grupo e adaptação à dinâmica ambiental (CORDELL, 1989, MALDONADO, 1993).

Além do acesso aos recursos e da posse territorial, na pesca o saber tradicional regula as estratégias adaptativas às condições ambientais (CUNHA, 1987; 2007) e sociais (CORDELL, 1983; 1989) e a movimentação no mar, ao mesmo tempo em que constrói o espaço marítimo (MALDONADO, 1993).

Estes aspectos adaptativos e dinâmicos relacionados às tomadas de decisão no uso do território estão imbuídos do que Nietschmann (1989) considera quarta dimensão do território: o tempo. Neste sentido, como será visto em 2.4, o tempo também é conhecido e, consequentemente, apropriado, portanto, territorializado.

\subsection{Memória coletiva e conhecimento tradicional do tempo}

O domínio do tempo é histórico nas diversas sociedades e culturas. Desde a antiguidade a invenção do calendário ${ }^{21}$ desponta como instrumento fundamental para domesticar o tempo natural. A construção do calendário se dá pela observação dos ciclos naturais (movimento da Lua ou do Sol, do ciclo das estações, da alternância do dia e da noite) e seu conteúdo está ligado ao complexo jogo de relações entre as exigências da religião e a vida econômica e social (GIDDENS, 1991; LE GOFF, 2003).

Além do princípio ordenador da percepção coletiva do tempo (GOUREVITCH, 1975), o calendário, em qualquer sociedade, quando oficializado, também é usado como instrumento de um poder religioso e/ou laico sobre o tempo individual e coletivo, permitindo de fato exercer um controle dos homens nas suas atividades econômicosociais (o trabalho, o tempo livre, as festas, etc). Assenhorar-se do tempo, tal como do espaço, é de fundamental importância para quem quer triunfar e reinar. Neste sentido, o calendário é um dos grandes emblemas e instrumentos de poder (GIDDENS, 1991; LE GOFF, 2003).

O calendário oficial, no entanto, é apenas o tempo social do poder ideológico dominante. Isso quer dizer que nos interstícios do controle social há possibilidade de grupos se estruturarem socialmente em lógicas de tempo distintas, embora algumas

\footnotetext{
${ }^{21}$ A origem etimológica da palavra calendário é do latim calendarium, o livro de contas dos empréstimos que eram pagos nas calendae nos primeiro dia dos meses romanos (HOUAISS e VILLEN, 2004).
} 
vezes articulada ou influenciada pelo tempo social preponderante (GOUREVITCH, 1975). Assim, a resistência dos povos, nações e das sociedades profundamente radicadas nas suas tradições e práticas se torna tão arcaica quanto à imposição de um tempo/calendário.

No entanto, entre 1300 e 1650, processos de rupturas importantes na percepção do tempo ligado aos ciclos naturais (THOMPSON, 1998), impensáveis fora da teologia cristã (GOUREVITCH, 1975; PIETTRE, 1997), ocorrem na Europa Ocidental ${ }^{22}$. Na transição entre a Baixa Idade Média e a Era Moderna, com a retomada do desenvolvimento das cidades e cidades-mercados, houve uma lenta, ainda que progressiva, modificação da percepção tradicional da natureza, ao mesmo tempo em que se adotava relógios para a marcação do tempo nas igrejas e locais públicos. $\mathrm{Na}$ civilização urbana nascente, o ciclo de produção dos artesãos já não era determinado pela alternância das estações e o homem se percebia criador de um mundo cada vez mais distinto do mundo agrário. Essa ruptura durante a instalação da Era Moderna, só se consolida com o advento da Revolução Industrial quando há uma difusão geral dos relógios, no momento em que se necessitava de uma medida mais exata do tempo e uma sincronização maior do trabalho, e um monopólio do Estado Moderno na imposição de cronogramas precisos e calendários aos trabalhadores. A medição incorpora consequências: o tempo passa a ser abstraído, mecânico, fixo/rígido/homogêneo, linearizado (portanto irreversível) e contabilizado ${ }^{23}$ (GOUREVITCH, 1975; THOMPSON, 1998; LE GOFF, 2003).

É com base nessa abstração que se dá toda a dialética entre os tempos moderno e tradicional. Ainda que a medição do tempo moderno seja calculada a partir de observações astronômicas, há uma guinada do foco perceptivo individual e coletivo dos movimentos que ocorrem na natureza aos criados ou regulados por nós, dos ciclos naturais ao relógio ${ }^{24}$ (GARDET, 1975; THOMPSON, 1998; LE GOFF, 2003, HALBWACHS, 2006). Ambas as divisões do tempo são guiadas por mudanças e

\footnotetext{
22 A partir de interpretações do Novo Testamento, o tempo também é vivido como um processo escatológico e, portanto, se "estende em linha" (GOUREVITCHT, 1975). Sobre as contradições da concepção de tempo na Idade Média ver Gourevitch (1975) e Piettre (1997).

${ }^{23} \mathrm{O}$ tempo da modernidade é transformado em números (PIETTRE, 1997) dentro de espaços de tempo homogêneos para fins de monetarização. O valor do tempo é reduzido a dinheiro: "pois o tempo agora é moeda" (THOMPSON, 1998: 272).

${ }^{24}$ Segundo Ricoeur (1975), a medição do tempo pelo relógio é só mais uma consequência da nossa modalidade científica e técnica de mediar a realidade.
} 
movimentos que ocorrem em corpos materiais ${ }^{25}$ (HALBWACHS, 2006), porém, no mundo moderno ele é abstraído (THOMPSON, 2003) do que Boncompagno da Signa chama de "sinais de memória",26 (LE GOFF, 2003).

Para Boncompagno os "sinais de memória" seriam manifestações da natureza como, por exemplo, o canto do galo (LE GOFF, 2003). Neste sentido, nas sociedades tradicionais, como os Nuer, a contagem do tempo consiste numa série de concepções das mudanças naturais através da seleção de pontos de referência que é determinada pela significação que essas mudanças naturais têm para as atividades humanas (EVANS-PRITCHARD, 2007).

Incorpora-se aqui a denominação de "sinais de memória" de Boncompagno para os marcos temporais ligados aos movimentos da natureza, mas é necessária a criação de um conceito próprio a partir de Halbwachs e Evans-Pritchard. Os "sinais de memória" seriam, portanto, pontos de referências tomados pelo grupo tradicional, transmitidos de geração em geração, que prenunciam o retorno periódico de certos fenômenos materiais da natureza grávidos de significados. Neste sentido, os "sinais de memória" são os mecanismos utilizados pelas populações tradicionais para se adaptarem a dinâmica natural do mundo ao passo que materializa o tempo no espaço. Ou seja, os "sinais de memória" proporcionam a necessária intersecção entre tempo e espaço para a adaptação do ser no mundo.

Como este conceito será utilizado no estudo da construção do tempo na pesca da Coréia, há duas importantes implicações: a primeira que o mundo em que os pescadores pensam e se adaptam através dos "sinais de memória" é o ambiente estuarino; e a segunda é que o escopo de "sinais de memória" a serem analisados liga-se à memória-hábito (fenômenos naturais estão ligados a lembranças úteis ao trabalho social). Assim, nesta dissertação, os "sinais de memória" analisados restringem-se àqueles que são úteis a atividade pesqueira.

\footnotetext{
${ }^{25}$ A referência material é necessária ao ser humano para se estabelecer uma relação com o mundo circundante e um continuum da consciência pessoal e coletiva (LEITE, 2007).

${ }^{26}$ Os "sinais de memória", citado por Bompagno da Signa em a Rhetorica novíssima, também é chamado na mesma obra de "sinais mnemônicos" (Por ex.: o canto do galo) (LE GOFF, 2003). Gardet (1975), cita como exemplo das "marcas do tempo" manifestações concretas da natureza como ventos que anunciam chuvas, silêncio da natureza que indica mudança na direção dos ventos etc. Chesneaux (1989), cita os "sinais" como "os lugares de memória": marcos inscritos na duração que fundamentam a identidade social e coletiva. Outros autores, como Giddens (1991), se referem aos "sinais" como "marcadores sócioespaciais". Já Pietre (1997) utiliza a denominação "marcas temporais" não só para se referir aos referenciais naturais, mas também às "marcas numéricas" como o relógio.
} 
O cálculo do tempo, portanto, que constituía a base da vida cotidiana nas culturas pré-modernas, sempre vinculou tempo e espaço incorporando consequências contrárias as da modernidade: tempo localizado em seu ambiente natural, flexível/irregular/heterogêneo, cíclico (portanto reversível) e não-contabilizado $g$ (CHESNEAUX, 1989; GIDDENS, 1991). Neste sentido, Maurice Halbwachs asserta:

\begin{abstract}
Ora, no campo o tempo se divide segundo uma ordem de ocupações, que por sua vez se regulam pelo curso da natureza animal ou vegetal. É preciso esperar que o trigo brote da terra, que os animais tenham posto seus ovos ou parido seus filhotes, que as tetas das vacas estejam cheias. Não há mecanismo que possa precipitar essas operações. O tempo é exatamente o que deve ser em tal grupo e entre tais pessoas, cujo pensamento assumiu um comportamento de acordo com suas necessidades e tradições. Há períodos de pressa, dias em que descansamos, mas estas são irregularidades que têm a ver com o conteúdo do tempo e não alteram seu curso. (2006: 144).
\end{abstract}

Neste sentido, as irregularidades e flexibilidades dos ecossistemas naturais tomam seu quinhão no ritmo e na experiência temporal, ou temporalidade ${ }^{27}$, das populações tradicionais mediante as referências temporais materializadas nos ciclos naturais (HALBWACHS, 2006). Em meio à compreensão do conteúdo qualitativo do tempo cotidiano, há um "saber esperar" 28 pela maturação de uma situação à medida que os ecossistemas “tomam seu tempo" (REHFELD, 1988; CHESNEAUX, 1989).

A partir disso, pode-se concluir três aspectos importantes que se desdobram subsequentemente. Primeiro que o conhecimento do tempo nas comunidades tradicionais pode ser entendido como uma forma de conhecimento do espaço $^{29}$ (GARDET, 1975), o espaço em movimento. Segundo, os "sinais de memória" representam meios de orientação e construção de ações no tempo (KAGAME, 1975; ELIAS, 1998). Terceiro que o tempo presente, tanto quanto tempo de espera ou de ação em função dos "sinais de memória", é um período de tempo muito variável (GARDET, 1975; BRUNI, 2007).

Vale destacar que, além da dimensão utilitário-produtiva da percepção de tempo, também se engendra com a dimensão religiosa (GARDET, 1975), na medida em que algumas manifestações concretas da natureza são tomadas de valor sagrado e até,

\footnotetext{
${ }^{27}$ A temporalidade é a experiência do tempo presente/atual que resulta de um processo histórico-temporal de adaptação por aprendizado (REHFIELD, 1988).

${ }^{28} \mathrm{Na}$ cultura hindu não há medo de se "perder tempo" porque o "tempo perdido" é um conteúdo conquistado (PANIKKAR, 1975).

${ }_{29}$ A este tipo de conhecimento do espaço (em movimento) Gardet (1975) batiza de "conhecimento prático do tempo".
} 
algumas vezes, irrompem em rituais religiosos ${ }^{30}$ (ELÍADE, 1992). Consequentemente, as festas e rituais também podem condensar um tempo cósmico e mitológico (PANIKKAR, 1975).

Nas sociedades modernas, porém, houve uma significativa redução da dependência em relação às variações e irregularidades das forças naturais devido ao controle do tempo em nível abstrato (ELIAS, 1998). O espaço-tempo da modernidade é organizado em sistemas rígidos, tempo técnico-social, a partir do quais o funcionamento flexível dos ritmos biológicos naturais são cada vez mais desprezados e desqualificados. Abre-se um conflito com os profundos ritmos das forças naturais na medida em que nos separamos da temporalidade biológica e natural (CHESNEAUX, 1989). Portanto, não há apenas um "desencaixe" entre espaço e tempo, como pontua Antony Giddens (1991), mas também entre homem e espaço-tempo (CHESNEAUX, 1989).

Os relógios não são capazes de indicar o tempo como duração, ou seja, definido pela relação do anterior com o posterior, um passado e um futuro, mas somente o instante pontual, efêmero. O tempo da modernidade se contrai no imediato, é um tempo sem duração (CHESNEAUX, 1989; BHABHA, 1998). O relógio passa a expressar um tempo "vazio"31 e o esvaziamento do tempo é pré-condição para o “esvaziamento do espaço" (GIDDENS, 1991). Neste sentido, Carlos (2001) ao analizar a homogeinização do tempo e do espaço no maior centro urbano-industrial do Brasil evidencia a produção de "espaços amnésicos" resultante de um "tempo efêmero".

Nas comunidades tradicionais pesqueiras, a interpretação da linguagem da natureza e a orientação no espaço se dão pela leitura dos "sinais" (CARDOSO, 2001) ou “indicadores de tempo" (CUNHA e ROUGEULLE, 1989), ou seja, pela materialização do tempo nos movimentos do mar, do vento, dos peixes, das algas, no som, na tonalidade e no cheiro das águas, no vôo das aves marinhas, etc (CUNHA E ROUGEULLE, 1989; CARDOSO, 2001), que expressam, de um lado, as próprias leis internas da natureza marinha/estuarina e, de outro, o próprio modo cultural específíco dos pescadores interagirem com os seus recursos territoriais ${ }^{32}$ (CUNHA, 2007).

\footnotetext{
${ }^{30}$ Em algumas sociedades tradicionais nenhum acontecimento é considerado puramente profano: segundo Panikkar (1975) no estudo do povo hindu e Kagame (1975) no estudo do povo bantu, a separação entre sagrado e profano nas manifestações temporais materializadas na natureza seria artificial.

31 Bérgson qualifica o tempo homogêneo e mecânico da modernidade como um tempo "vazio de consciência" (HALBWACHS, 2006: 125).

${ }^{32}$ Segundo Cardoso (2001), a observação destes sinais se dá em terra e no mar: "Em terra os animais também fornecem sinais de mudança de tempo" (: 43).
} 
A representação individual e coletiva do meio, inclusive do espaço em movimento, definem as estratégias adaptativas às flutuações/dinâmicas do ecossistema marítimo/estuarino (ondas, marés, correntes, ventos, tempestades, ressacas, migração e lugares dos peixes, influência lunar, etc): sistema de posse, técnicas de pesca e movimentação no mar (CUNHA E ROUGEULLE, 1989; MALDONADO, 1993; CUNHA, 2007). Ou seja, a representação individual e coletiva do tempo na pesca embasa operações e decisões de quando, como e onde ir pescar.

Portanto, nos modos como os grupos pesqueiros se movimentam, se articulam e se situam em termos espaciais e temporais é que os homens se distanciam e se aproximam, pertencem ou se excluem, construindo as organizações em que vivem (MALDONADO, 1993). A ordem social é, antes de mais nada, um ritmo, um tempo (FRAXE, 2000).

Finalmente, como pôde ser visto, a apropriação do tempo, através dos "sinais de memória", é uma forma de se apropriar do espaço em movimento, ou seja, do tempo materializado no espaço (intersecção entre tempo e espaço). A apropriação do espaço, como foi visto no subitem anterior, "territorializa" o espaço (RAFFESTIN, 1993). Neste sentido, territorializar o espaço em movimento é territorializar o tempo. A partir do espaço e do tempo, pré-concepções para se pensar a natureza e se adaptar (tomadas de decisões) às suas flutuações, as comunidades pesqueiras constróem o espaço marítimo como um espaço sócio-cultural próprio (MALDONADO, 1993), o seu território.

A seguir, tem-se uma breve descrição dos sistemas ambiental e social em estudo e, após, inicia-se a análise dos dados sobre o território coreano. 
3. A LAGOA DOS PATOS

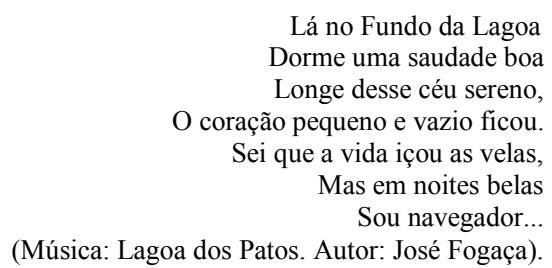

\subsection{Descrição da área de estudo}

O Atlântico Sul entre a África e a América do Sul tem seu clima e circulação oceanográfica de larga escala controlados pelo anticiclone do Atlântico Sul (SEELIGER e ODEBRECHT, 1998). À oeste as correntes marinhas que se dirigem ao sul (Corrente do Brasil) e as que se dirigem ao norte (Corrente das Malvinas) convergem entre as Latitudes $32-40^{\circ} \mathrm{S}$ e são forçadas em direção ao oceano, o que dá origem a Convergência Subtropical do Atlântico Sudoeste (CASTELO e MÖLLER, 1977). A área norte desta convergência influencia diretamente cerca de $100 \mathrm{mil} \mathrm{km}{ }^{2}$ da região sul brasileira. As interações entre a Corrente do Brasil oligotrófica, a Corrente das Malvinas rica em nutrientes e a descarga continental tornam a região uma importante área de criação, alimentação e reprodução dos estoques pesqueiros de origem subtropical e antártica que utilizam ambas as correntes para se locomoverem a longas distâncias (SEEGLIER e ODEBRECHT, 1998). Portanto, estas interações são responsáveis pela produção biológica entre planície costeira e o talude (LONGHURST et al, 1995).

Toda a planície costeira do Rio Grande do Sul está sob influência do centro de alta pressão do anticiclone do Atlântico Sul que modifica e influencia o ciclo sazonal do clima, ou seja, verões quentes e invernos frios, além da predominância dos ventos $\mathrm{NE}$ ao longo do ano e SO durante as passagens de frentes frias. O padrão e a passagem destas frentes frias controlam a precipitação pluviométrica anual (1200-1500 mm) que varia marcadamente a cada ano (KLEIN, 1998). As variações interanuais no Atlântico Sudoeste parecem estar relacionadas aos ciclos de El Niño (NOBRE et al, 1986, GAN, 1992) trazendo consequências aos processos meteorológicos, como as chuvas excessivas no sul do Brasil, e biogeoquímicos costeiros e marinhos (KOUSKY e CAVALCANTI, 1984; CIOTTI et al, 1995).

A Lagoa dos Patos, maior lagoa do tipo "estrangulada" do mundo, é a formação dominante na planície costeira do extremo sul do Brasil $(250 \mathrm{~km}$ de 
comprimento por $40 \mathrm{~km}$ de largura e $5 \mathrm{~m}$ de profundidade, em média) e se estende na direção NE-SO entre as Lat. $30^{\circ} 30^{\prime}$ S e Long. $32^{\circ} 12^{\prime}$ S. A Lagoa recebe água doce de uma bacia de drenagem de $201.626 \mathrm{~km}^{2}$ e em $971 \mathrm{~km}^{2}$ dos seus $10227 \mathrm{~km}^{2}$ de superfície, aproximadamente $10 \%$ do total, existe uma mistura entre massas de água de origens contrastantes: a água doce de origem fluvial e a água do mar do oceano adjacente (KJERVFE, 1986; ASMUS, 1998), o que constitui neste corpo de água costeiro semifechado uma zona estuarina (MIRANDA et al, 2002) (Figura 1). Em consequência, a distribuição vertical de salinidade varia do tipo cunha salina a bem misturado $^{33}$ (CALLIARI, 1980; MÖLLER et al., 2001).

A zona estuarina da Lagoa dos Patos tem como principais forçantes da sua circulação, em ordem de importância, ventos predominantes do quadrante NE-SO e a descarga fluvial que se refletem nos perfis de temperatura e salinidade. Os ciclos sazonais de temperatura do ar também influenciam a temperatura da água estuarina ${ }^{34}$. A maré é considerada negligível, ou seja, a região é de micromaré (amplitude média de 0,47 m e máxima de 1,2 m) ${ }^{35}$ (KJORFVE, 1986; GARCIA, 1998; NIENCHESKI e BAUMGARTEN, 1998; MIRANDA et al, 2002).

O limite interior (cabeceira) da zona de mistura estuarina (ZM) da Lagoa dos Patos, geralmente está localizado a cerca de $70 \mathrm{~km}$ da entrada do estuário (linha imaginária que liga a ponta dos Lençóis a ponta das Feitorias) (Figura 1), porém esse limite é deslocado conforme as fortes descargas fluviais, características do final do inverno e início da primavera, e a baixa a moderada descarga, que ocorre o resto do ano, para o sul e para o norte, respectivamente (MOLLER e CASTAING, 1999; MIRANDA et al, 2002). Em função da descarga fluvial, as médias de temperatura da água são menores no inverno do que nas outras estações, enquanto a salinidade normalmente é maior no verão e outono do que no inverno e primavera (VIEIRA, 1985; 1991). Ocasionalmente, a ZM pode se infiltrar $150 \mathrm{~km}$ no estuário assim como pode se estender para as águas costeiras (GARCIA, 1998). Em ocasiões de El Niño, há um aumento da descarga fluvial e, consequentemente, a formação de uma enorme pluma na

\footnotetext{
${ }^{33}$ Sobre os critérios de classificação dos estuários ver Miranda et al. (2002).

${ }^{34}$ Apesar da temperatura do ar e da água serem geralmente coincidentes, em média a temperatura do ar é um pouco maior que a da água o ano todo com exceção do inverno, quando as médias da água são um pouco maiores (MARQUES, 1994).

35 Os sinais de maré astronômica são misturados, mas há predominância da maré diurna (HERZ, 1977), refletindo a proximidade com o ponto anfidrômico (MÖLLER e CASTAING, 1999).
} 
plataforma continental pela água carreada através da Lagoa dos Patos (CIOTTI et al, 1995).

Embora poucas espécies de peixes possam suportar o estresse da variação da salinidade inerente aos estuários, existe uma grande biomassa de peixes associada à alta produtividade primária dos estuários. Apesar de apenas 29 espécies de peixes terem seus ovos e larvas no estuário da Lagoa dos Patos e nas suas adjacências (SINQUE e MUELBERT, 1998), 110 espécies de peixes são encontradas no interior do estuário sendo as fases de pós-larvas, juvenis e sub-adultos, as mais frequentemente coletadas (CHAO et al, 1982; VIEIRA, 1991). Portanto, a Lagoa dos Patos constitui a mais importante área de criação, reprodução e alimentação de grande parte dos peixes que ocorrem no litoral sul do Brasil (CHAO et al, 1982; VIEIRA et al, 1998).

A maioria dos peixes que ocorrem no estuário da Lagoa dos Patos, e em qualquer outro estuário, é de origem marinha (VIEIRA et al, 1998). A partir disso, divide-se as espécies em estuarino-residentes e em espécies cuja presença depende do sucesso reprodutivo nas áreas marinhas ou nas águas doces adjacentes ao estuário (Op. Cit.) e das principais forçantes estuarinas que determinam a sua estrutura salina (intrusão de água salgada e descarga fluvial) e, portanto, a entrada de ovos e larvas de peixes (SINQUE e MUELBERT, 1998). A temperatura, por sua vez, parece controlar a distribuição sazonal da desova e do ictioplâncton neste estuário e, portanto, vincula-se ao sucesso reprodutivo tanto das estuarino-residentes quanto das visitantes ocasionais ou sazonais (Op. Cit.).

Sobretudo em estuários de médias latitudes, caso do estuário da Lagoa dos Patos, as mudanças sazonais da temperatura e da salinidade atuam sinergisticamente na composição da assembléia de peixes estuarinos: a baixa temperatura e salinidade das águas estuarinas, associadas ao regime de vazante, reduzem a diversidade de espécies (em geral, na primavera e no inverno), enquanto a alta temperatura e salinidade contribuem para a alta diversidade, já que favorecem intrusões de larvas e peixes (em geral, no verão e no outono) (VIEIRA, 1991). O camarão-rosa também tem sua penetração neste estuário junto às águas oceânicas condicionada às principais forçantes estuarinas (D’INCAO, 1991). Dentre as espécies registradas no estuário da Lagoa dos Patos, uma semi-anádroma (Netuma barba) e outra estuarino-dependente 
(Micropogonias furnieri) são as mais abundantes (CHAO et al, 1982; MARQUES, 1994; VIEIRA, 1991) ${ }^{36}$.

A hipótese mais plausível para a forte presença de peixes, apesar do estresse fisiológico, é a abundância de alimento e proteção contra os predadores, necessárias para o desenvolvimento do peixe durante sua fase juvenil, que pode ser encontrado nas zonas rasas do estuário (VIEIRA et al, 1998).

Neste sentido, uma característica geomorfológica no estuário da Lagoa dos Patos que tem importantes implicações hidrodinâmicas e biológicas, que vale pontuar, é a presença de dois principais ambientes: as baías costeiras rasas $(<1,5 \mathrm{~m})$ e protegidas (enseadas) e o corpo de água central aberto e profundo ( $>5 \mathrm{~m}$ ) ('canal') (BONILHA e ASMUS, 1994; MOLLER e CASTAING, 1999). A ictiofauna estuarina, com base na sua distribuição espacial e temporal, também pode ser dividida em função do gradiente de profundidade: associações de águas rasas, de meia-água ou pelágica e de águas profundas (VIEIRA et al, 1998).

A Ilha dos Marinheiros localiza-se na porção central da maior enseada rasa da zona estuarina (Lat. $31^{\circ} 58^{\prime}$ e $32^{\circ} 02^{\prime}$ S e Long. $52^{\circ} 05^{\prime}$ e $52^{\circ} 12^{\prime} \mathrm{O}$ ), o Saco do Arraial, e apenas a sua face oeste tem contato com a região do canal do estuário (Figura 1). Em relação à zona de canal, estas enseadas têm circulação reduzida e sedimento arenoso (SEELIGER, 1998). Segundo Giordano (2005; 2007; 2008), há duas forçantes que atuam na circulação do Saco do Arraial: a descarga fluvial em períodos úmidos e os ventos em períodos úmidos ou secos.

Assim como as outras ilhas e margens do estuário da Lagoa dos Patos, a Ilha dos Marinheiros tem suas margens entre-marés ocupadas por marismas. Estes marismas do extremo sul do Brasil possuem espécies de clima temperado frio e tropical, o que caracteriza a Lagoa dos Patos como um ecossistema de uma região de transição biogeográfica temperada quente (COSTA, 1998). Devido à baixa hidrodinâmica e profundidade e às condições mixohalinas do Saco do Arraial, próximo às suas margens há colonização por fanerógamas marinhas submersas como a Ruppia maritima, Zannichellia palustris, Potamogeton striatus, Myriophyllum brasiliense e Ceratophyllum demersum (CAFRUNI, 1983; SEELIGER, 1998). A presença de $R$. maritima influencia de forma positiva a abundância de peracáridos epifaunais, de

${ }^{36}$ É característico dos estuários temperados serem numericamente dominados por poucas espécies (Vieira, 2001). 
juvenis de crustáceos decápodos e o recrutamento de poliquetas da infauna. Fatores como a baixa profundidade, a elevada biomassa bentônica, a proteção oferecida pela pradaria de $R$. maritima, a presença de marismas e o aproveitamento do zoobentos na alimentação de peixes e decápodes, indicam que estas enseadas representam uma valiosa zona de criação ('berçário') de diversas espécies de organismos marinhos na região (MARQUES, 1994; GERALDI, 1997). Dentre os peixes e os crustáceos de importância comercial, $65 \%$ da média anual de captura do estuário são beneficiadas pelas pradarias submersas e áreas aquáticas de marismas (COSTA et al, 1997).

Dentre as espécies de crustáceos que utilizam as zonas rasas como áreas de criação, vale ressaltar duas espécies de importância comercial: o siri-azul (Callinectes sapidus) e o camarão-rosa (Farfantepenaeus paulensis). Ambas têm fases de seu ciclo de vida associadas às pradarias de Ruppia maritima (BEMVENUTI, 1998; OLIVEIRA, 2005; RODRIGUES, 2006).

Apesar do bagre (Netuma barba) e da corvina (Micropogonias furnieri) serem as espécies estuarinas dominantes, nas zonas rasas os peixes-rei Xenomelaniris brasiliensis e Odontesthes bonariensis constituem as espécies dominantes (CHAO et al, 1982; BEMVENUTI, 1984; 1987; 1990; VIEIRA, 1991). Outras espécies de peixes como a tainha (Mugil platanus), Gobionellus shufeldti (sem nome comum), sardinhamanjuba (Planichthys platana), a corvina (Micropogonias furnieri), o barrigudinho (Jenynsia lineata), Ramnogaster arcuata (sem nome comum) e o linguado (Paralichthys orbignyanus) são frequentes ou típicas de zonas rasas (CHAO et al, 1982; VIEIRA, 1985; MARQUES, 1994; VIEIRA et al, 1998, FISHER et al, 2004).

\subsection{Histórico da pesca na Lagoa dos Patos}

A Lagoa dos Patos, antes da chegada dos colonizadores portugueses, foi palco de práticas pesqueiras de habitantes nativos, especialmente índios Guaranis, considerados exímios pescadores (MARQUES, 1980; MENESTRINO e MENTZ RIBEIRO, 1995; FREITAS, 2003). Historicamente, indígenas da região de Rio Grande e do Prata foram chamados Minuanos e Charruas ${ }^{37}$, respectivamente, (FREITAS, 2003;

\footnotetext{
${ }^{37}$ Apesar dos registros Charruas serem mais frequentes na bacia do Prata, também há registros na região da cidade do Rio Grande (RUIVO, 1994).
} 
MENESTRINO e MENTZ RIBEIRO, 1995) e se tem registros arqueológicos de outros subgrupos Guaranis que habitavam ou se deslocavam às margens da Lagoa dos Patos ${ }^{38}$ como os Tapes encontrados na região de São Lourenço do Sul (PASQUOTTO, 2005), de Rio Grande e de Estreito (TORRES, 1995; FREITAS, 2003;) e os Arachanes encontrados na de São Lourenço do Sul (PASQUOTTO, 2005). A diversidade de artes de pesca dos Tapes e Arachanes (canoas feitas de troncos de árvores escavados 'pirogas' -; pesca com anzóis feitos com pequenas pedras ou dentes de animais; pesca com lanças, arco e flecha e peneiras, 'puçás' - pequenas redes ligadas a um arco de madeira -; pesca com venenos naturais em arroios e enseadas, etc.) permite inferir que dispunham de técnicas para capturar a grande maioria das espécies de pescados da Lagoa, banhados e arroios. Algumas pescas eram realizadas somente por homens (pesca de arco e flecha, por exemplo) e outras por homens e mulheres (pesca com peneiras e redes, por exemplo) (Op. Cit.).

Com a chegada dos primeiros colonizadores portugueses no Rio Grande do Sul e a fundação da província de Rio Grande de São Pedro (em 1737), os indígenas começaram a ser afastados para regiões de acesso mais restrito, devido à incursão de bandeirantes a fim de capturar escravos nativos (Op. Cit.). A tomada da província de Rio Grande de São Pedro pelos espanhóis dispersou os habitantes luso-brasileiros em vários pontos da margem ocidental e oriental da Lagoa dos Patos até o limite norte onde fundam a Freguesia de São Luís de Mostardas, hoje município de Mostardas (MARQUES, 1980; TORRES, 1995). Para assegurar a conquista do território em meio aos conflitos, a Coroa Portuguesa concede posse de sesmarias a representantes militares do Exército de Portugal no Brasil, especialmente terras de fronteiras e do entorno de rios e de lagoas navegáveis. Neste contexto, todo o entorno da Lagoa dos Patos adquire importância especial por ser a principal saída para o oceano da região hoje conhecida como o Estado do Rio Grande do Sul. Como consequência, por volta de 1780, o sistema pesqueiro indígena entra em decadência (MARQUES, 1980; PASQUOTTO, 2005).

A partir de então, a pesca na Lagoa dos Patos passa a ser praticada também por descendentes de açorianos, em regime familiar ${ }^{39}$, que obedecem a um ritmo de complementaridade entre pesca e agricultura. Apesar do clima de hostilidade, entre os

\footnotetext{
${ }^{38}$ Não só a Lagoa dos Patos, mas em todo complexo Lagunar Mangueira-Patos-Mirim há registros da presença de Minuanos e Charruas (MARQUES, 1980).

${ }^{39}$ Geralmente os homens trabalhavam nas atividades de captura e homens, mulheres e crianças trabalhavam na confecção dos petrechos, no processamento e na comercialização do pescado (PASQUOTTO, 2005).
} 
colonos e os índios sucede-se um intercâmbio técnico e cultural na arte pesqueira, ainda que reduzido (SOUZA, 2001; PASQUOTTO, 2005; ADOMILLI, 2007). Torres (1995), numa análise da obra de Simão Pereira de Sá sobre o contexto de formação do povoado de Rio Grande de São Pedro, pontua as duas faces (eliminação/incorporação) da relação entre índios e portugueses:

O confronto com indígenas, diferente da mera substituição destes "bárbaros" por agentes da civilização, encontrou uma série de outras mediações e dinâmicas entre europeus e índios. A dinâmica biológica e cultural foi mais intensa que o receituário da mera substituição dos "bárbaros" numa visão linear-excludente (: 28-29).

A incorporação de elementos indígenas se dá num processo de readaptação das técnicas de captura e na absorção do conhecimento nativo sobre o ambiente biofísico da região por parte dos conquistadores para a praticabilidade da pesca no local (ADOMILLI, 2007). Em São Lourenço do Sul, na região das charqueadas, há registros de aporte de conhecimentos e técnicas da cultura afrodescendente ao sistema pesqueiro já na segunda metade do século XVIII (PASQUOTTO, 2005), enquanto que em São José do Norte os registros apontam influências afrodescendentes apenas após a segunda metade do século XX (final da década de 1970) ${ }^{40} 41$ (ADOMILLI, 2007).

No entanto, é nas últimas décadas do século XIX até meados do século XX que ocorre o fluxo imigratório mais precípuo: o desembarque dos imigrantes portugueses oriundos, sobretudo, de Povoa do Varzim. Estes imigrantes se concentraram no Rio de Janeiro, onde formam comunidades de pescadores, e posteriormente parte deles se transfere para outras regiões do país, entre elas destaca-se a cidade do Rio Grande e São José do Norte (SOUZA, 2001; ADOMILLI, 2007). Inicialmente, a relação dos poveiros com os pescadores nativos, descendentes de açorianos, é de pouco contato com predominância de casamentos endogâmicos e a formação de uma comunidade de trabalho étnica bem coesa para a manutenção das suas tradições. Os poveiros voltam-se para a subsistência e a base do trabalho é o núcleo familiar (ADOMILLI, 2007).

\footnotetext{
40 Segundo Silva (2001: 11), as culturas de canoeiros, marinheiros e pescadores no Brasil portam de influências européias, africanas e indígenas "profusas e inseparáveis". Mais precisamente a faixa do litoral entre SC e RS, segundo Diegues e Arruda (2001), é ocupada por descendentes de imigrantes da ilha dos Açores, da Madeira e portugueses continentais que se estabeleceram no século XVIII e se miscigenaram com índios e negros.

${ }^{41}$ Estes registros da influência da cultura afrodescendente revertem uma tendência das bibliografias locais de se postular a ausência de elementos da cultura negra na cultura pesqueira gaúcha. Em Marques (1980: 14), por exemplo, se acredita que "o pescador é quase totalmente constituído de elemento branco. Os pretos (...) se teriam dedicado ao serviço do pastoreio, às charqueadas e ao trabalho da lavoura".
} 
Portadores de uma experiência pesqueira de séculos de desenvolvimento, os poveiros dispõem de técnicas consideradas de "maior capacidade" de captura de pescado que as dos descendentes de açorianos que, até aquele momento, poucos se dedicam exclusivamente à pesca ${ }^{42}$ (PASQUOTTO, 2005; ADOMILLI, 2007).

Ainda assim, como outrora os descendentes de açorianos, os poveiros incorporam à sua "bagagem técnica" elementos nativos que favorecem a adequação do seu conhecimento ao novo ambiente generoso em estoques de diversas espécies de pescado (PASQUOTO, 2005). Disso deriva que, até recentemente, em diferentes regiões do Estado ainda é possível encontrar traços da cultura indígena na cultura pesqueira do Rio Grande do Sul como armadilhas, as "pirogas" e toponímias registradas nos trabalhos de Pasquotto (2005), de Adomilli (2007) e de Kalikoski et al (in press).

Além das trocas de conhecimentos, há a introdução de novos materiais (corda, arames e ferro) e novas ferramentas para a construção de canoas ${ }^{43}$ e de um processo produtivo mercantil na região (PASQUOTTO, 2005; ADOMILLI, 2007). Neste momento, o pescado passa a ser salgado não apenas para consumo próprio, mas também como forma de conservação, o que possibilita seu transporte e comércio às cidades mais distantes (ÁVILA MARTINS, 2001).

Alguns imigrantes portugueses adquiriram capital suficiente, outros já chegaram de Portugal capitalizados como F. Marques Leal Pancada, J. Cunha do Amaral, J. Gomes Sequeira, Francisco Furtado, M. Pereira de Almeida, F. Fernandes Troina, Torquato R. Pontes, Abel F. Dourado e Albano G. de Oliveira (Op. Cit.), para a implantação de estabelecimentos destinados às salgas e à comercialização do pescado para outras regiões do Brasil, como o Sudeste e o Nordeste, e até para a Europa ${ }^{44}$ (SOUZA, 2001; PASQUOTTO, 2005; ADOMILLI, 2007). Ihering (2003) registra a existência no Rio Grande do Sul de indústrias de conserva e exportação de peixe para o

\footnotetext{
${ }^{42}$ Independente da chegada dos poveiros, algumas famílias de pescadores de São Lourenço do Sul que realizavam a pesca de forma complementar as Sesmarias e à agricultura já começavam, no final do século XIX e início do XX, a se dedicar exclusivamente à pesca (PASQUOTTO, 2005).

${ }^{43}$ A introdução de novas ferramentas e materiais reforça o processo de "externalização" (dependência de produtos do comércio) que já existia no sistema de pesca de subsistência com a compra das linhas de gerbo e de algodão para a confecção das redes e panos de algodão para a confecção de velas. Por outro lado, persistiu até os anos 1960/70 a utilização de elementos retirados diretamente da natureza, alguns dos quais provavelmente remontam à experiência pesqueira indígena: bóias de "porongo" ou "corticeira", pedras para peso nas redes, fibras para armadilhas e "infusão" de redes feitas de "capororóca" (Rapanea spp) e "aroeira" (Schinus molle), ambas nativas da orla da Lagoa dos Patos, para aumentar a durabilidade das redes, pois suas cascas são ricas em tanino (COSTA, 1999).

${ }^{44}$ Em São Lourenço do Sul surgiram compradores de peixe salgado de outras regiões do país (PASQUOTTO, 2005).
} 
Sudeste do Brasil já no século XIX e segundo Souza (2001), até a metade do século XX, as salgas já eram mais de vinte ${ }^{45}$. O surgimento das "salgas" estabelece um marco: 0 início das indústrias de pesca (conserva de peixe) no Rio Grande do Sul, embora tanto a captura quanto o processamento do pescado ainda seja feito com base no trabalho familiar (ÁVILA MARTINS, 2001), e a diferenciação do sistema pesqueiro do Rio Grande do Sul (PASQUOTTO, 2005). Vinícius Frizzo Pasquotto (2005) descreve este processo em São Lourenço do Sul:

\begin{abstract}
Esse sistema pesqueiro começa a ser reformulado em meados do século XIX, com o fim da escravidão e com a decadência do ciclo econômico baseado nas charqueadas. O encerramento do modelo econômico de produção de charque para exportação coincide, em São Lourenço do Sul, com o início da colonização alemã, com um modelo agrícola mais diversificado e com o surgimento também de atividades não agrícolas. A criação de um "mercado interno" e o desenvolvimento populacional do município geram as condições para que o mercado se converta, de uma forma mais intensa, em "mercadoria". Estes aspectos foram responsáveis por significativas mudanças em relação aos diversos aspectos - sociais, econômicos e culturais - que influenciam a evolução e diferenciação dos sistemas pesqueiros, produzindo as formas de relação entre pescadores e natureza que estão nas origens dos processos sociais hoje presentes no município. É neste contexto que surge, conceitualmente, o ator social "pescador artesanal" entendido como aqueles indivíduos ou famílias que, empregando seus conhecimentos sobre o ambiente e sua cultura técnica, realizam a captura do pescado objetivando sua realização enquanto mercadoria, como a principal forma de assegurar sua reprodução social (: 80).
\end{abstract}

Apesar das particularidades no processo de diferenciação do sistema pesqueiro em São Lourenço do Sul que não são generalizáveis para todo o entorno da Lagoa dos Patos (colonização alemã e desfasamento temporal da evolução dos sistemas pesqueiros entre as diferentes províncias), as características da diferenciação dos sistemas pesqueiros ao menos em todo o estuário da Lagoa dos Patos parecem guardar similitudes, pois, segundo Martins (2006), todo o sul do Rio Grande do Sul experimentou um modelo de colonização pautada nos grandes latifúndios escravocratas e pecuaristas ('charqueadas'). Pasquotto (2005) indica uma tendência de Rio Grande experimentar o processo de diferenciação primeiro por ser um "núcleo urbano relativamente desenvolvido" (: 80). Em São José do Norte é a modernização da agricultura (mecanização e utilização de fertilizantes e, posteriormente, agrotóxicos) na primeira metade do século XX e a decadência do ciclo da cebola na segunda metade do

\footnotetext{
${ }^{45}$ As indústrias do tipo familiar concentraram-se basicamente na cidade de Rio Grande, com pequenas filiais em São José do Norte, Pelotas e São Lourenço do Sul, devido à facilidade de acesso ao mar e à matéria prima, a presença do maior porto do sul do país e a mão-de-obra disponível (pescadores artesanais). Pelos mesmos motivos, junto à política econômica do governo federal, esta cidade ergue nos anos 1960 o maior parque pesqueiro do estado (SOUZA, 2001).
} 
mesmo século $^{46}$ que levam os agricultores e os pescadores-agricultores a se especializarem na atividade pesqueira, ou seja, tornarem-se "pescadores artesanais" (ADOMILLI, 2007).

As mudanças no sistema de produção pesqueiro ampliam a capacidade de captura (acompanhado pelo aumento da demanda), o raio de ação, o emprego de mãode-obra e a exigência de uma estrutura de capital necessária para colocar em prática o próprio sistema de produção, o que desdobra diferenciações internas entre os pescadores. É neste contexto que surgem as "parelhas" importante notar que apesar da aquisição de embarcações maiores ${ }^{48}$ e de mais redes, da exploração de pontos de pesca mais distantes, da demanda de alta mão-de-obra e de mudanças nas relações de trabalho", as "parelhas" ainda apresentam "alto grau de artesanalidade" e se caracterizam mais por incorporar mão-de-obra do que por excluir, observado posteriormente com a incorporação de tecnologias "modernas" como o uso de gelo e de motores de combustão interna. Ainda que a "parelha" tenha passado a constituir a unidade de planejamento e captura do pescado no lugar da unidade familiar, as famílias dos pescadores, os pescadores e suas "parelhas", percorriam a Lagoa acampando nas margens e nas ilhas. Dentro do processo produtivo da pesca, as famílias ainda desempenhavam um papel fundamental: a "salga" (PASQUOTTO, 2005). As mulheres, entre outras tarefas ${ }^{50}$, evisceravam os peixes e as crianças limpavam o

\footnotetext{
${ }^{46}$ Segundo Adomilli (2007) estes dois processos ocorridos no século XX levam a um esvaziamento da zona rural e uma concentração populacional na zona urbana de São José do Norte.

${ }^{47}$ Há variações quanto a definição de "parelhas" entre os autores pesquisados. Segundo Barcellos (1966: 21) consiste em uma "espécie de sociedade de co-participação de 20 a 30 homens ('proeiros') nos quais um é proprietário ('patrão') e tem parte nos lucros maior que os demais", pois descontava as despesas da alimentação, motor, barco, redes, combustível, etc, dividindo o restante em tantas partes for o número de integrantes da "parelha". Por conseguinte, o "patrão" obtém mais partes. Já Pasquotto (2005) define mais detalhadamente as categorias de pescadores na parelha (além do 'patrão' e do 'proeiro', há os 'remadores', 'lançadores de redes' e o 'caidor na água') e o número de participantes do "grupo" em "mais de 10 indivíduos". A partir da vivência em campo, constata-se que essas variações referem-se às variações entre as comunidades pesqueiras ao longo de toda a Lagoa dos Patos, uma vez que na Coréia as "parelhas" teriam uma terceira configuração.

${ }^{48}$ Apesar da demanda por embarcações maiores, elas ainda eram movidas em sua maioria à vela e à remo. Os motores de centro a gasolina estão apenas começando a surgir (PASQUOTTO, 2005).

${ }^{49}$ A captura do pescado deixa de constituir uma atividade planejada e executada pela unidade familiar e passa a ser feita pela "parelha": ainda que o patrão discuta com o grupo de pescadores de sua "parelha" sobre o processo de trabalho, a decisão final recai sobre sua pessoa, o proprietário dos meios de produção (PASQUOTTO, 2005).

${ }^{50}$ Há registros de mulheres em São José do Norte que, além da salga relativa ao peixe e ao camarão, trabalhavam no descasque do camarão, em pescas próximas à praia, no arrasto em águas rasas e na confecção de redes. Com as sucessivas transformações nas relações de trabalho e de produção no sistema pesqueiro gaúcho nos anos 1960/70, a organização do trabalho no núcleo familiar vai sofrendo profundas mudanças (ADOMILLI, 2007).
} 
estômago ${ }^{51}$ dos bagres que eram secos e salgados nos varais, assim como outras partes do pescado que, após secos, formavam pilhas que eram cobertas com lonas (COSTA, 1999).

A partir da década de 1940, a urbanização do litoral de Santa Catarina, sobretudo em Florianópolis, associada à especulação imobiliária decorrente do turismo, vai gerar outro fluxo migratório, porém sazonal, para o Rio Grande do Sul: o de pescadores catarinenses $^{52} 53$ (PASQUOTTO, 2005; ADOMILLI, 2007). Atrás das safras de peixes que vêm do sul, os pescadores catarinenses surgiam em grupos cada vez maiores no litoral gaúcho e na Lagoa dos Patos que foram sendo absorvidos nas "parelhas" dos portugueses, que já tinham carência de mão-de-obra para sua manutenção. A falta de mão-de-obra e a relação com os catarinenses acabaram por desestruturar as parelhas dos portugueses que, gradativamente, dão lugar às "parelhas dos catarinas", em maior número e compostas de menos homens (ADOMILLI, 2007). A frequência sistemática com que os pescadores catarinenses visitam o litoral gaúcho também influencia a evolução do sistema pesqueiro praticado no Rio Grande do Sul (PASQUOTTO, 2005), já que entre os pescadores gaúchos e catarinenses houve difusão e integração cultural ${ }^{54}$ (ADOMILLI, 2007).

Na década de 1950 têm-se mais algumas mudanças importantes que afetam o sistema pesqueiro: avanços no transporte rodoviário que permitem percorrer maiores distâncias em menos tempo; as indústrias, não mais exclusivamente familiares, diversificam as formas de processamento do pescado (salgado, enlatado, resfriado e congelado) agregando valor ao pescado; as "parelhas" passam a utilizar mais

\footnotetext{
${ }^{51} \mathrm{O}$ estômago do bagre era um material muito procurado e caro naquele momento histórico, pois se destinava a produção de colas pelas indústrias (COSTA, 1999).

${ }^{52}$ Há a desapropriação de uma série de comunidades de pescadores-agricultores de origem açoriana e a desorganização de seu modo de vida que passam a se dedicar exclusivamente à pesca. Esta passagem maciça da agricultura para a pesca significa o prenúncio de situações dramáticas. $\mathrm{O}$ excesso de pescadores em alguns locais gera conflitos e disputas pelos espaços e as inovações tecnológicas e a ampliação do mercado pesqueiro em Santa Catarina levam à intensificação da atividade. Consequentemente, surgem os "pescadores migrantes" ou "andorinhas" que em caminhões se lançam às praias de outros estados, entre elas as do Rio Grande do Sul, para a sobrevivência de inúmeras famílias catarinenses: "a fuga de miséria" (DIEGUES, 1983; ADOMILLI, 2007).

${ }^{53}$ A escolha do RS como destino migratório, no entanto, não se dá por acaso: a ligação entre Laguna e a praça da Colônia remonta a 1680 quando as tropas iniciam sua descida pelo litoral para a consolidação da influência portuguesa no Prata. Posteriormente, com a doação de algumas sesmarias na primeira metade do séc. XVIII os tropeiros também se apropriam deste percurso litorâneo e na primeira metade do século XX, são os pescadores catarinenses que continuam este trânsito (MARQUES, 1980).

${ }^{54}$ Os casamentos exogâmicos, e, portanto, a formação de uma rede de parentesco, também contribuem para a integração cultural entre os pescadores catarinenses e gaúchos: tanto pescadores do RS casam-se com as filhas dos pescadores "catarinas" quanto os pescadores catarinas contraem casamentos com as gaúchas (ADOMILLI, 2002, 2007).
} 
frequentemente motor de centro a gasolina que posteriormente é substituído por motor a diesel; alguns barcos motorizados ${ }^{55}$ passam a levar gelo para os acampados e levar a produção de pescados para a indústria, pois o processo de salga começa a ser realizado dentro das indústrias (PASQUOTTO, 2005); e, em 1951, inicia-se a pesca com navios industriais escandinavos na costa oceânica do $\mathrm{RS}^{56}$ que só é consolidada posteriormente através de políticas públicas $^{57}$ (ASSEMBLÉIA LEGISLATIVA RS, 1975 apud PASQUOTTO, 2005) $)^{58}$.

Com as novas formas de processamento, conservação e transporte, sobretudo após as condições pós-decreto 221/1967, outras espécies de pescado, além do bagre e da miragaia, entram na pauta comercial das indústrias de beneficiamento: tainha, corvina, anchova, camarão, linguado, traíra e jundiá, entre outras. As indústrias familiares de conserva, entretanto, entram em decadência e desaparecem nos anos 1970 e peixes como o biru e a savelha perdem mercado na consolidação deste novo sistema pesqueiro (SOUZA, 2001; PASQUOTTO, 2005).

A indústria da pesca no RS até meados dos anos 1960 exibe uma evolução lenta e gradual e a pesca artesanal, praticada no estuário da Lagoa dos Patos e já na costa litorânea próxima, ainda constituía a principal fornecedora de pescado para a indústria de processamento. Dados estatísticos contemporâneos ilustram bem a hegemonia da pesca artesanal: nas safras de 1945 e 1946, o desembarque médio alcança 12.387 toneladas advindo exclusivamente da pesca artesanal enquanto que ainda entre 1955 e 1961 a média anual de desembarque da pesca artesanal é de 20.243 toneladas e da pesca industrial, 4.272 toneladas (SOUZA, 2001; PASQUOTTO, 2005).

A íntima relação entre o comportamento da pesca artesanal e os fatores bióticos e abióticos do seu espaço, entretanto, dificultava a operação das indústrias de pesca. Devido à grande imprevisibilidade e variabilidade, as "safras" pesqueiras, frequentemente, redundavam em grande concentração de uma ou de outra espécie de pescado em um período relativamente curto de tempo. As câmaras de refrigeração, os

\footnotetext{
${ }^{55}$ Em São Lourenço do Sul, estes barcos motorizados recebem o nome de "chacareiras", pois antigamente eram utilizadas para transporte dos produtos das chácaras coloniais (PASQUOTTO, 2005).

${ }^{56}$ A exploração da zona costeira marítima, no entanto, inicia-se em 1947 com embarcações da região: a parelha "Albamar/Brisamar" (BARCELLOS et al 1991).

${ }^{57}$ Foram contratados com autorização presidencial seis barcos escandinavos com $1 / 3$ de tripulação estrangeira e $2 / 3$ de tripulação brasileira para realizar a pesca oceânica experimentalmente. Os resultados positivos é que permitiu apontamentos a favor do incremento da atividade pesqueira industrial a ser implantada na década de 1960 (ASSEMBLÉIA LEGISLATIVA RS, 1975 apud PASQUOTTO, 2005).

${ }^{58}$ RIO GRANDE DO SUL. Relatório sobre a pesca, 1975. Porto Alegre: Assembléia Legislativa do Rio Grande do Sul. Relatório da Comissão especial sobre pesca, 1975.
} 
estoques de gelo e a capacidade de industrialização eram esgotados rapidamente, o que leva a um superdimensionamento das plantas industriais que normalmente ficam ociosas em 30\% ou em até 50\% (PASQUOTTO, 2005).

Não é por acaso que relatórios e diagnósticos deste mesmo período apontavam para um consenso acerca de uma frota pesqueira industrial complementar à pesca artesanal com o objetivo de suprir lacunas da pesca artesanal nas "safras secas". Logo em 1962, a produção da pesca industrial atinge patamares semelhantes ao da produção artesanal, o que se estende até 1968, quando ainda não se dispunha de incentivos do governo federal para o desenvolvimento do setor industrial. Neste momento histórico, a pesca industrial se dava principalmente em águas Argentinas e Uruguaias ${ }^{59}$, portanto atuava sob recursos pesqueiros diferentes da pesca artesanal, o que não se traduzia em grandes conflitos entre pesca artesanal e industrial (BARCELLOS, 1966; ASSEMBLÉIA LEGISLATIVA, 1975 apud PASQUOTTO, 2005), embora os tornasse iminentes.

Entre 1966 e 1969, no entanto, acontecimentos nacionais e internacionais lançam bases para uma ruptura no sistema pesqueiro gaúcho que se desenrola no sistema pesqueiro atual. Em 1967, a tecnocracia consolidada com o golpe militar de 1964 no Brasil baixa o decreto 221 que constitui, a partir do seu ideário modernizante, uma tentativa de tornar a pesca uma indústria de base nacional. Em consonância com o modelo de desenvolvimento então adotado e a "necessidade" de modernização da atividade pesqueira, com ênfase no conhecimento científico como instrumento para o progresso no setor pesqueiro, tem-se um comunicado do Ministério da Agricultura em $1968^{60}$ :

\begin{abstract}
A falta de conhecimentos científicos dos indivíduos dedicados à pesca, comercial ou diletante, a respeito do comportamento dos peixes, contribui para que esta atividade ainda seja submetida a tradições e superstições (...). A pesca, além de problema econômico o é, também, social. Estruturada e racionalizada incorporaria à vida nacional razoável potencial humano. Ampliada e, com forte apoio técnico, modernizada afetaria, em parte, a economia nacional (: 3-6).
\end{abstract}

Em 1966, a Argentina anuncia sua soberania numa faixa de 200 milhas náuticas, ou seja, decreta seu mar territorial e nele impede a pesca de navios

\footnotetext{
${ }^{59}$ Neste contexto, a pesca industrial se dedica com maior avidez aos cardumes oriundos da corrente das Malvinas, sobretudo os de Merluza (Merluccius hubbsi) (PASQUOTTO, 2005).

${ }^{60}$ Desde o decreto $\mathrm{n}^{\circ} 9672$ de 1912 a pesca estava subordinada ao Ministério da Agricultura (SOUZA, 2001).
} 
estrangeiros. A decisão ecoa no Uruguai em 1969 onde medidas restritivas a navios estrangeiros são tomadas e a atividade pesqueira passa a ser permitida apenas mediante pagamento de licenças e taxas. Em alguns anos, torna-se inviável a pesca em águas uruguaias para as frotas industriais brasileiras ${ }^{61}$.

Assim, os conflitos que eram apenas potenciais irrompem em decorrência da atuação sobre as mesmas bases de recursos naturais da pesca artesanal e da pesca industrial, como assevera Pasquotto (2005):

\begin{abstract}
Com a área de atuação restringida, a pesca industrial, que a partir deste momento passaria a contar com fortes investimentos do setor público, passa a diversificar as artes de pesca e a implementar um esforço de pesca significativamente maior, em especial na Barra do Rio Grande e sobre as espécies de interesse artesanal, como camarões (Penaeus sp), tainha, bagre (Netuma barba) e corvina (Micropogonias furnieri) os quais adentram a Lagoa dos Patos para crescimento e/ou reprodução. Evidencia-se, assim, um conflito até então latente entre pesca artesanal e industrial, através da atuação de ambas sobre a mesma base de recursos naturais $(: 56-57)^{62}$.
\end{abstract}

A partir do decreto-lei $\mathrm{n}^{\circ} 221$ da Superintendência do Desenvolvimento da Pesca (SUDEPE) ${ }^{63}$, as políticas pesqueiras voltam-se principalmente à concessão de incentivos fiscais ${ }^{64}$ às grandes empresas, ou seja, a intervenção Estatal na política pesqueira tem importância fundamental num processo de acumulação empresarialcapitalista (DIEGUES, 1983). Em consequência, muitas indústrias familiares de conserva de pescado desaparecem de 1960 a 1980, sobretudo nos anos 1970 (SOUZA, 2001).

A região Sudeste e Sul atrai cerca de $97 \%$ de todos os recursos fiscais no período de 1967/74 (DIEGUES, 1983) e o Sul do Brasil, segundo maior volume de captação, cerca de 24,51\% de 1967 a 1986 (SOUZA, 2001), o que demonstra grande desigualdade regional na distribuição destes recursos (DIEGUES, 1983). Tais políticas fornecem um grande volume de recursos para o RS, sobretudo na década de 1970, com

\footnotetext{
${ }^{61}$ No encontro das indústrias de pesca do RS (FIERGS, 1996) e em alguns trabalhos acadêmicos locais como o de Lima (1999), que ecoam a ideologia destas indústrias, o decreto do mar territorial é tido como um dos motivos da quebra das indústrias de pesca no RS. No entanto, como será visto mais adiante, o modelo de desenvolvimento pesqueiro adotado é que se desdobra na crise pesqueira gaúcha e nacional.

${ }^{62}$ Grifo do autor.

${ }^{63}$ A SUDEPE foi instituída pela lei delegada $\mathrm{n}^{\circ} 10$ de 1962 num quadro de desenvolvimento da economia brasileira cujo objetivo é criar setores modernos e dinâmicos na economia, entre eles o setor pesqueiro. No entanto, o decreto-lei 221 de 1967 é que tem o peso de "marco determinante" ao que se refere à pesca nacional (DIEGUES, 1983) e para o RS (SOUZA, 2001).

${ }^{64}$ Do total de Cr\$1742 milhões dos recursos destinados à pesca até fins de 1972, Cr\$1191 milhões são incentivos fiscais (DIEGUES, 1983).
} 
o qual algumas indústrias já existentes se modernizam e outras se instalam. As indústrias formam frotas particulares de pesca oceânica e surge a categoria social de "pescador embarcado". Este grande volume de recursos financeiros acaba favorecendo, entre outras coisas, o crescimento do volume de produção do pescado e a geração de emprego nas indústrias de pesca $^{65}$ (SOUZA, 2001; PASQUOTTO, 2005).

A geração de emprego, associada à desigualdade dos recursos distribuídos entre a pesca industrial e a artesanal ${ }^{66}$, expõe claramente o objetivo do decreto-lei da SUDEPE: atribuir à pequena pesca a função de um bolsão de força de trabalho barata para a frota empresarial-capitalista, já que há a crença na década de 1960 que os pescadores artesanais e pequenos armadores "não sabem trabalhar com técnicas modernas" além de "ignorantes, atrasados e pouco produtivos"67 (DIEGUES, 1983).

Em decorrência dos incentivos fiscais e do crédito rural para o custeio da pesca (específico para captura, conserva e beneficiamento de pescado), já a partir de 1969 o volume de produção pesqueira industrial foi sempre superior ao da artesanal apresentando tendência crescente de 1960 até 1974, mas decrescente nos anos seguintes: o ano de 1973 é o ápice da produção industrial com 67 mil toneladas com subsequentes quedas até as 28 mil toneladas de 1997 (Figura 3) (SOUZA, 2001).

Em 1976 são 30 indústrias de pesca em todo o estuário da Lagoa dos Patos (SOUZA, 2003), sendo 23 só na cidade de Rio Grande (ÁVILA MARTINS, 1995). A frota industrial de arrasto de fundo, como as parelhas e os arrasteiros, passam de 5 e 20, respectivamente, em 1961 (SOUZA, 2001) a 240 embarcações industriais atuando no litoral gaúcho em 1986, entre as do RS e as provenientes de outros estados (SUDEPE, 1988), o que gera crescimento das capturas acelerando a sobrepesca.

Em decorrência da sobrepesca, de exportadoras de pescado para outros estados e países até 1973, as indústrias pesqueiras gaúchas passam a importar significativamente até 1980 para atender a sua capacidade de processamento (Figura 3) (SOUZA, 2001). Ainda assim, segundo a SUDEPE (1988), a ociosidade das indústrias gaúchas chega a

\footnotetext{
${ }^{65}$ Com o êxodo rural em São José do Norte em função da modernização da agricultura, as mulheres são empregadas nas salgas e nas indústrias de pesca e os homens nas "parelhas" de pesca (ADOMILLI, 2007).

${ }^{66}$ A pesca artesanal recebeu menos de $12 \%$ do total de capital destinado à pesca empresarial até dezembro de 1978 (DIEGUES, 1983; SOUZA, 2001).

${ }^{67}$ Atualmente, este discurso ainda é encampado pela literatura científica no RS numa tentativa de desqualificar o conhecimento e manejo tradicionais em favor do conhecimento e do manejo científicos da pesca.
} 
40\% em 1980 com queda do número de empregos e dos salários ${ }^{68}$. Subsequentemente a crise se desdobra nas "silhuetas das unidades fabris desativadas" (ÁVILA MARTINS, 1995: 199): das 30 indústrias de pesca no estado em 1976, restam apenas 9 em 1996 sendo 8 apenas na cidade do Rio Grande (SOUZA, 2001); dos 17 mil empregados da indústria pesqueira na cidade do Rio Grande, restam apenas 2 mil (ÁVILA MARTINS, 1995). A queda do número de empresas e a concentração dos canais de comercialização acabam favorecendo a atuação dos "atravessadores" (SOUZA, 2003).

Entre 1983 a 1987 houve um novo aumento na produção de pescado no RS em relação ao período anterior (1980-82), devido à concentração do crédito rural $^{69}$, ao aumento do valor do pescado (SOUZA, 2001) e à diversificação na captura. Há empenho na captura de espécies até então não comercializadas como camarões, linguados e cações, em detrimento das que apresentavam sinais de sobrepesca no início dos anos 1980 como a corvina, a castanha, a pescadinha, a pescada e o pargo-rosa (BARCELLOS et al, 1991) 70 $^{71}$. Particularmente em 1985-86 o volume de pescado desembarcado pelas indústrias é da ordem de 45 mil toneladas e em 1986-87 o empresariado gaúcho acreditava numa mudança no hábito alimentar, devido ao aumento do consumo durante o Plano Cruzado. No entanto, a sua estabilização em 1988 provoca nova queda no nível de produção industrial. Na década de 1990 são vários os fatores que fazem a captura industrial manter o baixo volume de captura: sobrepesca de espécies, abertura comercial, e consequentemente as importações de pescado, e o fim dos incentivos fiscais e do crédito rural às empresas na segunda metade dos anos oitenta (SOUZA, 2001).

Além dos efeitos predatórios das indústrias de pesca sobre o estoque de pescado, a modernidade alcança o cerne do sistema pesqueiro artesanal através da

\footnotetext{
${ }^{68}$ A queda dos empregos e dos salários se dá pela comparação do ano de 1980 com 1975. De 1980-87, a queda do número de empregados na indústria pesqueira chega a $8,11 \%$ ao ano e, de 1987 a 1996, a queda é de 3,11\% ao ano (SOUZA, 2001).

${ }^{69}$ De 1978 a 1986, tanto no Brasil como no Rio Grande do Sul, houve uma tendência crescente de crédito rural aplicado à pesca, apesar das oscilações (SOUZA, 2001).

${ }^{70}$ Aqui há uma incoerência na literatura científica pesqueira do Rio Grande do Sul: Pasquotto (2005), como foi pontuado anteriormente, revela a comercialização de linguado e de camarão desde a década de 1950, como resultado das "novas formas de processamento", enquanto Barcellos et al (1991) aponta o início da comercialização na década de 1980, resultante da diversificação das espécies pescadas.

${ }^{71} \mathrm{O}$ peixe-rei (Odontesthes argentinensis) é uma das espécies de pescado apontada já em sobrepesca no ano de 1979 por Benvenuti (1984). Mas na conclusão, a baixa abundância deste peixe é colocada como "parece" estar relacionada à sobrepesca.
} 
incorporação de insumos modernos ${ }^{72}$ que repetem o efeito do aumento do volume de captura de pescado e reduzem o grau de artesanalidade, produzindo riscos e custos maiores. Cria-se a necessidade de se dedicar mais intensamente na pesca propriamente dita tanto para cobrir custos quanto para atender uma demanda maior, o que impossibilita muitos pescadores de realizar as etapas de processamento e comercialização, encampadas pelas indústrias e "atravessadores" (PASQUOTTO, 2005). Dessa forma, segundo Pasquotto (2005):

... os elementos que influenciam a reprodução das unidades de produção na pesca, e, por consequência, ao menos em parte, a própria reprodução social dos pescadores artesanais, passam a ter uma forte dependência das dinâmicas de mercado, tanto a juzante como a montante da pesca propriamente dita (: $58)$.

Há, portanto, segundo o mesmo autor, um processo de "mercantilização" da produção e "externalização" de fatores de decisão e etapas produtivas. Neste sentido, se for analisada a evolução da produção pesqueira artesanal, identifica-se uma tendência de crescimento em resposta à introdução destes elementos modernos na pesca artesanal, mas somente até 1972 quando o desembarque supera as 40 mil toneladas ${ }^{73}$ (SOUZA, 2001). A partir de então, aumenta consideravelmente a quantidade de rede necessária para alcançar o volume de captura desejado e o tamanho da malha diminui como um indicativo de sobrepesca. O aumento do esforço de pesca também se dá pela queda nos preços do pescado e do aumento dos preços dos principais insumos, principalmente o óleo diesel (PASQUOTTO, 2005).

O aumento da quantidade de redes e a diminuição das suas malhas aliada ao aumento da jornada de trabalho, do esforço de pesca e da distância percorrida, às novas formas de localização dos cardumes (sondas), ao sistema de partilhas ainda mais desiguais e à perda do respeito indicam uma desarticulação das relações sociais e do manejo tradicionais (Op. Cit.; ADOMILLI, 2007).

Outro fator de desarticulação do manejo tradicional é a forma centralizada de gestão dos recursos. Até a segunda metade dos anos 1960, praticamente não se tem

\footnotetext{
${ }^{72} \mathrm{O}$ uso generalizado de motores que amplia o raio de ação das "parelhas" e de sondas, a construção de depósitos para gelo nas embarcações para armazenar maiores volumes de pescado e permitir um período de trabalho mais prolongado (até 7 dias) e a grande quantidade de redes confeccioadas com fio de nylon, são alguns dos elementos do mundo moderno introduzidos na pesca artesanal com fins de aumento no volume de captura de pescado (PASQUOTTO, 2005).

${ }^{73}$ Nenhum outro ano antes, durante ou após o processo de modernização da pesca artesanal o desembarque pesqueiro superou este valor (SOUZA, 2001).
} 
normatizações que regulamentavam a pesca na Lagoa dos Patos. A partir de então, leis são criadas para impor um calendário e técnicas de pesca, como as do final da década de 70 (HAIMOVICI et al, 2006) e a INC/2004 que condiciona os atuais critérios de uso aos quais fica submetida à pesca artesanal ${ }^{74}$ (KALIKOSKI et al, 2002; ALMUDI et al, 2004; KALIKOSKI e VASCONCELOS, 2005; 2006).

Se por um lado o parque industrial praticamente desapareceu, por outro o volume de desembarque da pesca artesanal nos anos de 1996-97 atinge cerca de 15 mil toneladas (SOUZA, 2001), ou seja, os mesmos níveis da década de 1960 (Figura 3). O que se deve acentuar, porém, é que a queda no setor industrial foi mais acentuada que no artesanal e, portanto, o decréscimo no volume de captura total a partir de 1974 devese, em maior grau, ao decréscimo na captura advinda da pesca industrial (SOUZA, 2001).

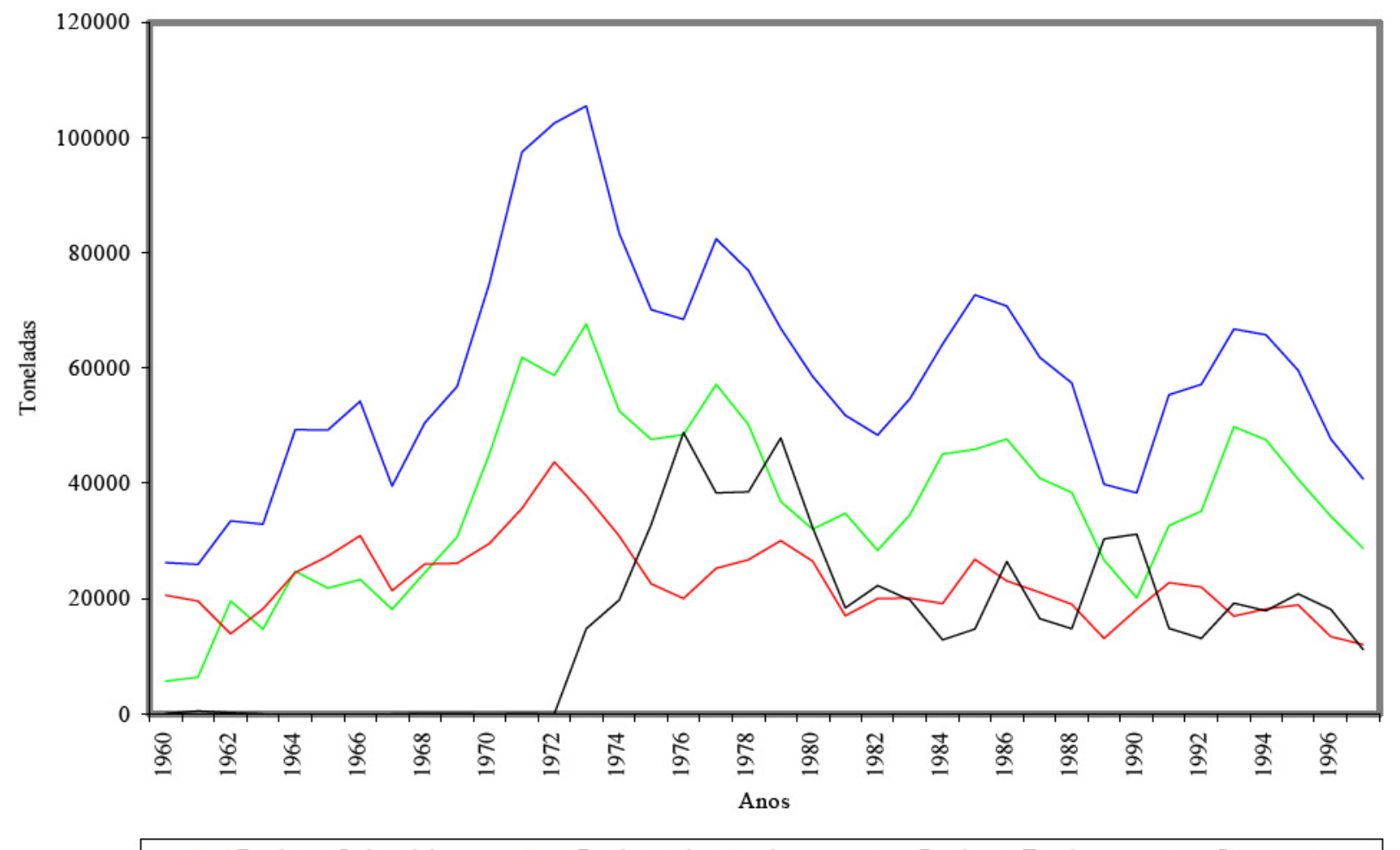

Fonte: SOUZA (2001).

Figura 3: Produção artesanal, industrial e total e importação do pescado no Rio Grande do Sul, em toneladas, no período de 1960 a 1997.

\footnotetext{
${ }^{74}$ Além do calendário tradicional que é desarticulado com a imposição de datas fixas para as "safras", a imposição de técnicas de pesca influenciou a mobilidade dos pescadores artesanais com a introdução de artes de pesca fixas (ALMUDI et al, 2004).
} 
A década de noventa, ainda sob os impactos sociais e ambientais do modelo de desenvolvimento no setor pesqueiro implementado durante a ditadura militar, é marcada por iniciativas de políticas públicas voltadas especificamente para a pesca artesanal. Em 1991, o governo federal institui um salário mínimo a cada pescador durante o período em que a pesca estiver proibida: é o "seguro-defeso"75. Além disso, em 1996 o pescador é enquadrado como beneficiário do Programa Nacional de Fortalecimento da Agricultura Familiar (PRONAF) ${ }^{76}$ e em 1998, em nível regional, o programa RS Rural abre uma linha específica para a pesca artesanal (PASQUOTTO, 2005).

Os impactos destes três programas na pesca artesanal é algo ainda um tanto desconhecido, mas dentro dos poucos dados disponíveis é possível inferir, segundo Pasquotto (2005), que possibilitam a manutenção dos meios de produção das diversas categorias de pescadores artesanais (patrão, proeiros, etc.) e a sua diferenciação/mobilidade entre categorias, sobretudo entre as mais precárias, o que ocorre através da aquisição de redes, motores, embarcações, etc.

A hibridação das culturas, a introdução de elementos da modernidade assim como a substituição/eliminação de alguns desses elementos, é um fato que ocorreu e que ainda ocorre na pesca gaúcha. Portanto, resta-nos reconhecer que apesar de todo o cronograma evolutivo do sistema pesqueiro gaúcho descrito aqui, ele encena processos predominantes, mas não exclusivos, como bem pontua Pasquotto (2005):

\begin{abstract}
É importante ressaltar que esta reconstituição da evolução dos sistemas pesqueiros, em nível regional e local, colocou ênfase em processos mais gerais e nos sistemas de produção na pesca artesanal que foram mais característicos dos diferentes momentos históricos. Entretanto, como é próprio do processo histórico, estes sistemas de produção, embora mais representativos, não ocorreram de forma exclusiva ao longo do tempo. Um olhar mais atento ao passado da atividade pesqueira demonstra que os sistemas de produção evoluem e se diferenciam, mas que, muitas vezes, formas mais tradicionais persistem, com pequenas modificações, até os dias atuais (: 89).
\end{abstract}

Diante dos escombros do ideário de modernidade fundado em 1967 que se constrói paulatinamente a partir de 1973 e se alonga até os dias atuais, ressalta-se a emergência de diferentes sistemas pesqueiros co-existentes nas comunidades pesqueiras distribuídas pelas "praias" da Lagoa dos Patos, como sugere Adomilli (2007). O resultado, portanto, é o inverso ao da homogeneidade modernizante. A heterogeneidade

\footnotetext{
${ }^{75}$ Lei n 8.8287 de 20 de dezembro de 1991.

${ }^{76}$ Decreto-lei no 1946 de 28 de julho de 1996.
} 
da pesca artesanal gaúcha ainda goza de fôlego para criar no seu cotidiano possibilidades de sobrevivência a esta crise sem precedentes. "Apesar dos pesares", enquanto do parque industrial pesqueiro gaúcho remanescem apenas acres "silhuetas", a pesca artesanal mais uma vez continua existindo... ${ }^{77}$

É neste contexto histórico da pesca na Lagoa dos Patos que se insere a comunidade em estudo, a Coréia da Ilha dos Marinheiros.

\subsection{Revisitando a Ilha dos Marinheiros}

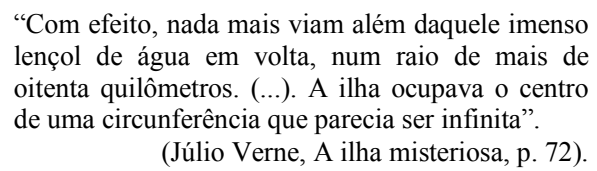

Antes da chegada dos colonizadores portugueses, a Ilha dos Marinheiros teve ocupação de duas culturas e tradições indígenas: a Vieira e a Tupiguarani ${ }^{78}$. Ambos se dedicavam à pesca ${ }^{79}$ e à caça, mas somente os Tupiguaranis realizam horticultura e a coivara $^{80}$. Em toda a ilha são encontrados sete sítios pré-coloniais ('sambaquis' ou 'cerritos'), sendo que em apenas um há evidência dos Tupiguaranis, onde se sugere uma sobreposição cultural destes sobre os da cultura Vieira como ocorreu nos outros locais de contato (fora da Ilha dos Marinheiros) entre as duas culturas. Com a colonização, os dominadores portugueses passam a denominar os nativos encontrados próximos a região da atual cidade de Rio Grande de "Minuanos" com os quais mantém intenso intercâmbio de elementos culturais (RUIVO, 1994; MENESTRINO e MENTZ RIBEIRO, 1995; FREITAS, 2003).

Já nos primórdios da província de Rio Grande de São Pedro, no ano de fundação do forte e presídio Jesus-Maria-José (1737), a Ilha dos Marinheiros serve

\footnotetext{
${ }^{77} \mathrm{O}$ fragmento "a pesca artesanal mais uma vez continua existindo" deste parágrafo inspira-se a partir da concepção de Barel (1974) apud Diegues (1983) sobre a articulação entre os modos de produção dominante e subordinado. Ao citar o modo de produção mercantil simples, ressalta que sua duração é maior do que os modos de produção dominantes com os quais se manteve ou mantém articulado/subordinado em diferentes momentos históricos: o feudal e o capitalista, respectivamente.

78 A distinção de duas "Tradições" é feita segundo material arqueológico coletado que pertencem a distintas tradições ceramistas (FREITAS, 2003).

${ }^{79}$ A pesca para os Vieira é uma atividade masculina com maior ênfase no verão. Dentre os petrechos utilizados estão as redes de fibras de tucum, embiras ou cipós, anzóis de ossos e os porongos (MENTZ RIBEIRO, 1991). Já nos Tupiguaranis homens e mulheres pescam, embora tipos de pesca distintos (FREITAS, 2003).

${ }^{80}$ Técnica agrícola que consiste em atear fogo após a derrubada da mata para plantação.
} 
como fonte de madeira e, posteriormente, de água e capim ${ }^{81}$. Até então considerada um lugar inóspito pelos portugueses, é usada como um local ideal para isolar pessoas tidas como arredias aos costumes da época (RUIVO, 1994).

Em função do grande desmatamento na ilha e do extermínio das fontes de madeira no entorno da ocupação humana no continente, o marechal e governador da província, André Ribeiro Coutinho, no ano de 1739, divide toda a Ilha dos Marinheiros em apenas três sesmarias ${ }^{82}$. É importante ressaltar que, apesar dos beneficiários da concessão destas sesmarias não terem efetivado a ocupação da ilha (RUIVO, 1994), eles representam o modo de produção e o poder político ${ }^{83}$ a ser consolidado na metade sul do $\mathrm{RS}^{84}$ e a tentativa de inserção da Ilha dos Marinheiros neste contexto.

A não ocupação da Ilha pelos sesmeeiros anteriores faz com que terras sejam distribuídas para outras pessoas de poder político-econômico como, entre outras, Francisco Antônio Afonso, o "Barão da Ilha", e o vereador João de Miranda Ribeiro, que recepciona o Imperador D. Pedro II em 1845 na sua residência de verão na Ilha dos Marinheiros. Por volta de 1745 chegam os primeiros imigrantes portugueses a trabalhar nas terras da Ilha dos Marinheiros como mão-de-obra "assalariada" ('diaristas' e 'de empreita' $^{85}$ (AZEVEDO, 2003) que, no entanto, parece co-existir com mão-de-obra negra escrava. A princípio, o tipo de cultivo adotado parece ter sido os hortigranjeiros ${ }^{86}$ ${ }^{87}$, como aponta observações de Domingos Alves Branco Moniz Barreto ainda no final

\footnotetext{
${ }^{81}$ Segundo Freitas (2003: 12) e Saint-Hilaire (1974), além do próprio presídio-forte Jesus-Maria-José ser construído com "paliçadas da madeira", as habitações, os hospitais, os quartéis e as trincheiras também são feitos de madeira retirada da Ilha dos Marinheiros.

${ }^{82}$ A medida, entretanto, não surte efeitos. Se Saint-Hilaire (1974: 57) em 1820 têm notícias que a Ilha dos Marinheiros "é em grande parte coberta de mata", o Barão Homem de Mello quando a visita em 1868 descreve o centro "tomado por cômoros de areia movediça". Em menos de dois séculos de domínio português, o desmatamento na ilha destrói sua mata nativa (AZEVEDO, 2003).

${ }^{83}$ Segundo Azevedo (2003), a ilha foi divida entre três Antônios: o capitão Antônio dos Anjos (insere-se no contexto dos conflitos militares entre portugueses e espanhóis), o estancieiro Antônio de Araújo Vilela e o mercador Antônio Gonçalves Pereira de Farias, ambos ligados à produção e comércio de charque e escravos em grandes latifúndios.

${ }^{84}$ Segundo Martins (2006), o modo de produção da metade sul do RS tem como bases os grandes latifúndios para a produção de charque.

${ }^{85}$ Os "diaristas" recebem por dia trabalhado na lavoura e os que trabalham "de empreitada" recebem por todo o serviço feito (Por exemplo: valor pago por 5 canteiros plantados de cebola). Valor, serviço e tempo de trabalho combinado entre patrão e empregado (AZEVEDO, 2003).

${ }^{86}$ Em vários pontos a literatura sobre a Ilha dos Marinheiros é controversa. Um dos momentos é a introdução da fruticultura: segundo Azevedo (2003) em 1790 já há registros da existência de fruticultura, enquanto para Ruivo (1994) a introdução se dá em 1850.

87 Apesar de algumas bibliografias locais se referirem a horticultura como de origem portuguesa, Berta Ribeiro (1995) alerta sobre a contribuição pré-colombiana em diversos elementos da horticultura praticada no Brasil como o cultivo de tomate e de batata-inglesa, que são de origem americana, e a rotação de cultura em pequenas roças. Em outras bibliografias locais citadas no início de 3.3 também é registrado na Ilha dos Marinheiros a presença de povos pré-colombianos, como os Tupiguaranis, que
} 
do séc. XVIII. Na primeira metade do século XIX, há registros de alguns pescadores que criam gado e de um quilombo, o Quilombo do negro Lucas, que mantêm ligação econômica não-agrícola com a cidade e/ou com os moradores dos arredores ${ }^{88}$ (MAESTRI, 1979 apud FREITAS, 2003) $)^{89}$.

Apesar da insuficiência historiográfica em torno das bases econômicas instauradas na ilha, é patente em toda a bibliografia que, a partir de meados do século XIX, há um incremento populacional, sobretudo por imigração portuguesa ${ }^{90}$, e econômico contínuo até o início do século XX devido à introdução da viticultura ${ }^{91}$ e da fruticultura: em 1850 já são quase mil habitantes, sendo $25 \%$ de negros, e no início do século XX atinge 9800 (RUIVO, 1994; AZEVEDO, 2003). A Ilha dos Marinheiros se consolida como a principal área agrícola do município de Rio Grande e sua produção de vinho, além de abastecer o mercado local, é exportada para o Rio de Janeiro e São Paulo (AZEVEDO, 2003; MARTINS, 2006).

A partir de então, inicia-se um processo lento e gradual de decadência econômica e populacional da ilha em função primeiramente da abolição da escravatura em 1888 e, principalmente, do contexto de oscilações econômicas entre o norte e o sul do Rio Grande do Sul no século XIX e a consolidação do norte, capitaneado por Porto Alegre, nas primeiras décadas do século XX como centro econômico do estado:

Esta transformação, do ponto de vista geográfico, significa a passagem da hegemonia econômica do sul para o norte, do latifúndio para a pequena propriedade, da pecuária para a lavoura. Obviamente as cabeças de zona Rio Grande e Porto Alegre - sofrem as consequências da mudança. A capital volta a tornar-se o grande centro econômico do Estado (SINGER, 1977: 164).

Além disso, a mudança de eixo econômico para o norte do Rio Grande do Sul abala o principal sustentáculo do modo de produção da Ilha dos Marinheiros quando as Serras Gaúchas, sobretudo Caxias, se especializam na produção de vinho com maior

também realizam a horticultura. Todos estes elementos culturais citados se fazem presentes na Ilha dos Marinheiros.

${ }^{88} \mathrm{O}$ quilombo do negro Lucas dura cerca de 10 anos e era protegido pelos "pretos, pardos e forros" que viviam na Ilha dos Marinheiros (MAESTRI, 1979 apud FREITAS, 2003).

${ }^{89}$ MAESTRI, Mário José. Quilombos e quilombolas em terras gaúchas. Porto Alegre: Escola Superior São Lourenço de Brindes, 1979.

90 Açorianos, barreiros, poveiros e, sobretudo, do norte de Portugal (região de Águeda) (AZEVEDO, 2003). Segundo Martins (2006) os imigrantes portugueses que se instalam na Ilha dos Marinheiros são de região agrícola de Portugal.

${ }^{91} \mathrm{O}$ início da viticultura remonta à primeira metade do século XIX (entre 1839 e 1842) quando o "Marquês de Lisboa" (José Marques de Lisboa) remete de Washington (EUA) mudas da uva Isabel (SOARES, 2005). 
produtividade e preços mais competitivos. O "golpe de misericórdia" na viticultura ocorre em meados da década de 1940 com a "praga da videira" produção de vinho entra em declínio, parece que não há alternativa para os produtores locais senão o retorno ao cultivo de hortigranjeiros ${ }^{93}$ (RIO GRANDE DO SUL, 1930ab; PREFEITURA MUNICIPAL DO RIO GRANDE, 1936), embora com ênfase no cultivo de cebola, cujo auge econômico, segundo Adomilli (2007), remonta as décadas de 1960 e 1970. Por mais que a cebola represente um ciclo econômico significativo, se contraposto ao ciclo econômico anterior, o da viticultura, denota um período de decadência. Prova disso, é que toda a efervescência observada até o início do século XX vai lenta e gradativamente dando lugar a uma inquietude e a um desâmino geral ${ }^{94}$ (RIO GRANDE DO SUL, 1930ab; PREFEITURA MUNICIPAL DO RIO GRANDE, 1936).

Paralelo a estes ciclos econômicos agrícolas, encontra-se o desenvolvimento industrial da cidade de Rio Grande que, embora apresente movimentos oscilatórios de crescimento e estagnação desde seu início na década de 1870 até seu término nas décadas de 1950-60 quando há o fechamento de boa parte do parque produtivo instalado (MARTINS, 2006), propicia uma evasão do meio rural ilhéu, sobretudo na época da implantação das Leis Trabalhistas ${ }^{95} 96$.

Na segunda metade do século XX mais um infausto abate sobre a economia da ilha provocando frequentes abandonos do meio rural: o monopólio dos produtos da CEASA de Porto Alegre e da CEAGESP de São Paulo nas feiras semanais e nos supermercados da cidade (ÁVILA MARTINS, 1995).

Internamente, durante todo o processo de declínio econômico da Ilha dos Marinheiros, sobrevêm dois processos: um intenso movimento migratório para as comunidades mais próximas a cidade cujas terras são abandonadas ou vendidas por baixos preços pelos grandes proprietários que emigram para a cidade e a especialização

\footnotetext{
${ }^{92}$ A década de 1940 parece emblemática para a derrocada da fruticultura e da viticultura na Ilha dos Marinheiros. Além da praga da videira em meados da década de 40, Moura (em preparação) em seu trabalho sobre a enchente de 1941, observa que a enchente estabelece um "divisor de águas" pelos ilhéus a respeito da fruticultura: "Depois da enchente, nenhum arvoredo nasceu mais na ilha" (Sr. Wandire, pescador-agricultor, 70 anos).

${ }_{93}$ Berta Ribeiro (1995: 234) registra um movimento parecido na Amazônia após o ciclo econômico da borracha onde a decadência "talvez tenha sido das melhores épocas para a população amazônica".

${ }^{94}$ De acordo com as inquietações políticas identificadas nos documentos da Prefeitura de Rio Grande, como Rio Grande do Sul (1930ab) e Prefeitura Municipal do Rio Grande (1936), a agricultura da cidade inteira encontra-se em profunda crise já no início da década de 1930.

${ }_{95}^{95}$ Decreto-Lei ${ }^{\circ} 5452$ de 1943.

${ }^{96}$ Informação obtida através de entrevistas.
} 
de pescadores-agricultores e de alguns agricultores ('chacreiros') na atividade pesqueira, ou seja, passa a surgir na ilha, em grande quantidade, a categoria de pescador artesanal.

A especialização na atividade pesqueira é tão febril que surge uma comunidade eminentemente pesqueira ainda no início da primeira metade do século $\mathrm{XX}$, a Marambaia, a mais antiga e tradicional comunidade pesqueira da Ilha dos Marinheiros, e pescadores-agricultores e pescadores artesanais em todas as comunidades. A única comunidade da ilha em que os "chacreiros" não adotam a atividade pesqueira, os Fundos da Ilha, praticamente desaparece.

Entre os Fundos da Ilha e a Marambaia, há um intenso e singular processo de migração para a "outra costa"97, a adoção da atividade pesqueira por alguns "chacreiros" e a ocupação de terras abandonadas por pescadores artesanais oriundos de outras comunidades pesqueiras ${ }^{98}$ da Lagoa dos Patos que se especializaram na pesca outrora. Neste local, pescadores artesanais, pescadores-agricultores e "chacreiros" passam a conviver num mesmo lugar. Mas não apenas: em função do preconceito dos "chacreiros", então elite econômica decadente, para com os pescadores, estes passam a reagir com violência física ao desprezo à sua profissão e à condição econômica proporcionada por ela. Portanto, nesta comunidade os pescadores artesanais e os "chacreiros" não apenas se encontram, mas também se confrontam. Constróem a identidade do lugar em torno dos conflitos entre os próprios nativos. É um "lugar de guerra” contemporâneo às Guerras das Coréias (1950-53). Entre a década de 1950-60 há a emergência de três, e não de apenas duas Coréias: a Coréia do Norte, a Coréia do Sul e a Coréia da Ilha dos Marinheiros ${ }^{99}$.

Hoje, sob os escombros dos tempos de outrora, remanescem, segundo o IBGE (2000), por volta de 1300 habitantes em toda a ilha. Cada uma de suas comunidades, a seu modo, revela cicatrizes da decadência que se construiu ao longo de todo o século $\mathrm{XX}$, mas particularmente duas delas as evidenciam mais: os Fundos da Ilha com os ecos silenciosos do seu desaparecimento e a Coréia com o surgimento da sua convivência beligerante. Somente esta última comunidade, no entanto, é alvo deste estudo em que seu território aquático é construído numa perspectiva etnooceanográfica.

\footnotetext{
97 “outra costa” é como os ilhéus da face norte da ilha chamam os da face sul da ilha e vice-versa.

${ }^{98}$ Esses pescadores artesanais cuja origem é São José do Norte, Torotama, Marambaia, Várzea, mudamse para esta região da Ilha dos Marinheiros em função, sobretudo, de casamentos exogâmicos.

99 As informações dos três últimos parágrafos foram obtidos através de entrevistas com os nativos.
} 


\section{4. ÁGUAS DA CORÉIA}

"O velho chamava-se Santiago. Dia após dia, (...), ia pescar na corrente do
Golfo. (...). Depois de saírem da boca da baía separaram-se, e cada um se
dirigiu para um ponto do oceano onde esperava encontrar peixe. O velho sabia
que ia muito ao largo (...), naquele ponto do oceano a que os pescadores
chamavam 'o grande poço', pois havia ali uma súbita profundidade de mil e
trezentos metros onde se juntavam peixes de todas as espécies...”.

(Ernest Hemingway, O velho e o mar, p. 9-26).

\subsection{O "Nosso Mar": território coletivo e territorialidade}

Para inaugurar a construção do espaço do território coreano, será criado um conjunto de "categorias" do espaço estuarino que irão compor e delimitar, nos subcapítulos subsequentes, o contexto territorial em que se dá a dinâmica etnooceanográfica da pesca. Para este fim, usa-se do conhecimento ecológico tradicional dos principais compartimentos ambientais que servem de referenciais materiais na natureza na construção do território de pesca. Entende-se que, como em Nietschmann (1989), a apropriação do espaço estuarino e a estruturação do território são feitas de acordo com as práticas de uso do espaço e dos recursos. Frequentemente, na literatura (MALDONADO, 1988; 1993; CUNHA, 1989; 2007; CUNHA e ROUGEULLE, 1989; RUDDLE, 2000), é apontado como principais compartimentos ambientais apropriados e com influência mútua na prática pesqueira o céu (forçantes climatológicas e astronômicas), o mar (ondas, marés, correntes, etc.) e os peixes (movimento migratório, habitats, nível trófico, etc.). Estes compartimentos, por sua vez, estão contidos no recorte epistemológico da oceanografia, o que não apenas permite, mas justifica a perspectiva etnooceanográfica na construção do território pesqueiro como conhecimento.

A ciência dos ilhéus coreanos do seu território grupal de pesca obedece a uma lógica de oposição binária. Todos os principais referenciais espaciais (bióticos ou abióticos) do território inextricavelmente passam pelo seu oposto: "um não vive sem o outro", disse um dos entrevistados (o 'Guega') quando explicava elementos territoriais postos e opostos, os simétricos que se balanceiam. A lógica da oposição binária na organização do mundo natural pelos pescadores é registrada pela literatura nacional, como em Marques (1991) para os pescadores estuarinos de Alagoas, e internacional, como em Nietschmann (1989) para os pescadores das ilhas oceânicas de Torres Strait. 
Em ambos os trabalhos, os eventos bióticos e abióticos são organizados em pares de oposição de tal forma que, simétricos, se balanceiam.

Um par de oposição é "aqui dentro" e "lá fora" (Figura 4). "Aqui dentro" é o espaço aquático do Saco do Arraial, profundamente conhecido e domesticado, enquanto "lá fora" é o espaço aquático do corpo principal do estuário, pouco conhecido e, por isso, mais hostil:

Lá fora é brabo, é pepino. (...). Lá num é aqui, qualqué ventinho... (Guega, pescador artesanal, 54 anos).

Aqui não, é um mar ${ }^{100}$ manso. O mar fora, da lagoa, (...), tu tinha que esperá duas-trêis hora pra agarrá uma folha de rede. Se tu agarrasse uma folha daquela de rede no mar quando ele tivesse alto, ele te tirava do caíco! (Sr. Meca, pescador-lavrador, 68 anos).

Aqui eu cunheço, lá fora eu num cunheço nada. (Milson, pescador artesanal, 24 anos).

As forçantes naturais não são as únicas características do mundo "lá pra fora" estranhas e selvagens. As relações sociais também geram um processo de estranhamento:

Eles ${ }^{101}$ comem tudo rapaz! Eu queria que tu visse: aí eles ficam que nem louco! Eles são igual uns bixo cara! São igual uns bixo! É igual um monte de abelha em cima de um monte de mel. (...). Tudo chapado e tudo louco! Armados (...). Eles corto rede, eles mete a faca, quando tá muita rede eles arrancam a faca e cortam. Cortam e vai embora! (...) se eles encontrá uma manta de tainha, eles bota a boca no mundo e chama pelos outro. E vem tudo! E por isso que eu digo: é que nem enxame de abelha! (Moisés, pescador artesanal, 45 anos).

As forçantes naturais e as relações sociais hostis engendram um terceiro fator limitante para os coreanos pescarem "lá pra fora”, os de meios de produção:

Se nóis fô cum os nosso barco lá pra fora, eles passam por cima do cara, pois o cara num tem máquina pra acompanhá eles, né.(...). Aí um achô peixe e veio tudo mundo pra cá e nóis tava ali e nóis vimo: se tu tivé motor que ande, máquina boa, tu chega lá rapidinho, mas se tu num tem fica pra trás. (...). Eles sai que nem louco, só se vê aquela língua de fumaça pra trás da casaria, fumaça branca de motor de caminhão. Só riscando fumaça pra trás, chega a abrí água. (...). Diz que esses barco aí, esses bote deles aí, eles dão uma acelerada eles só encosta o bojo deles no cara e mete o cara pra baixo d'água: 'Ah, ó, esbarrô morreram afogado'. (Moisés, pescador artesanal, 45 anos).

\footnotetext{
${ }^{100}$ Mesmo ao corpo de água estuarino, os pescadores coreanos se referem como "mar".

101 "Eles" que o Moisés se refere são os pescadores que pescam "lá fora".
} 
Então eu disse assim pro meu guri, meu guri disse que vai pescá lá fora, que eu mandei fazê um caíco, eu disse: 'Num vai! Num vai porque eu num deixo! Sozinho eu num te deixo não!'. Uma que o caíco que eu tenho pra pescá é muito pequeno, muito baixo, e outra que ele não cunhece o mar lá. ( $\mathrm{Sr}$. Meca, 68 anos, pescador-lavrador).

Graças aos fatores naturais pouco conhecidos e às relações sociais, os meios de produção, sobretudo as embarcações e o motor, passam a constituir fatores limitantes para se pescar "lá fora". Neste sentido, parece haver um "ranqueamento territorial" em função dos meios de produção na pesca: as comunidades que possuem melhores condições materiais de reprodução pescam no corpo principal do estuário e os que são materialmente mais pobres pescam nos baixios, caso da Coréia. Segundo Diegues (2004), em Cananéia também há a oposição entre o "mar de dentro", mais domesticado, e o "mar de fora", mais hostil, sendo que a este último só vão embarcações a motor ${ }^{102}$. Para Elíade (1992), é característica dos povos "primitivos" a oposição a que submetem o território habitado, delimitado, organizado e conhecido, o "nosso mundo", em relação ao espaço desconhecido, indeterminado, habitado por estranhos e caótico, o "outro mundo". Para os coreanos, o "nosso mundo" situa-se "aqui dentro", enquanto o "outro mundo" é "lá fora".

Apesar das limitações impostas (conhecimento, relações sociais e meios de produção), o mundo "lá fora" não é totalmente desconhecido já que é, de certa forma, ordenado:

Eu considero Lagoa dos Pato de Z3 lá pra cima. Eu costumo pensá que isso aqui é uns braço, entendesse, uns lado dela.(...). Aqui é os recanto que a gente trata (Sindo, pescador artesanal, 40 anos).

Quando tem enchente, a lagoa tá alta, né, a lagoa de Porto Alegre tá alta... (...). Dá muita chuva em Porto Alegre, diz assim: (...) 'Ah, vamo tê enchente'.(...). Lá pra cima que a gente diz é lá pro lado de Porto Alegre lá, né. Que a lagoa tá alta, que a lagoa de Porto Alegre tá alta, a Lagoa dos Patos... (Sr. Rui, pescador artesanal, 60 anos).

Se deixasse aquele peixe chegá a um ponto até dele subi pra cima, seria uma baita pesca pra nóis. (Amarildo, pescador artesanal, 40 anos).

Ainda que pouco conhecido, há uma categorização do espaço "lá fora". Assim como todo o espaço lagunar exterior ao Saco do Arraial é "lá pra fora", o "lá pra fora" à medida que se desloca em direção nordeste (NE) é mais propriamente designado de "lá

\footnotetext{
${ }^{102}$ Vale ressaltar que o "mar de dentro" e o "mar de fora" em Diegues (2004) se referem à laguna e ao oceano, respectivamente, enquanto na Coréia o "aqui dentro" e o "lá fora" se refere ao Saco do Arraial (a maior enseada estuarina) e ao corpo principal do estuarino, respectivamente.
} 
pra cima" e, subsequentemente, após a colônia de pescadores Z3 ou o rio São Gonçalo (pertencente à cidade de Pelotas), de "lá pra Porto Alegre" ou "lá pra lagoa"103. Por outro lado, à medida que se desloca para sul é chamado de "lá pra baixo" e afora "a Barra" é "lá pro oceano" ou "lá no oceano" (Figura 4). É a partir desta ordenação do mundo natural "lá pra fora" que são identificadas a origem de massas de água e de "peixes"104 que passam pelo Saco do Arraial.

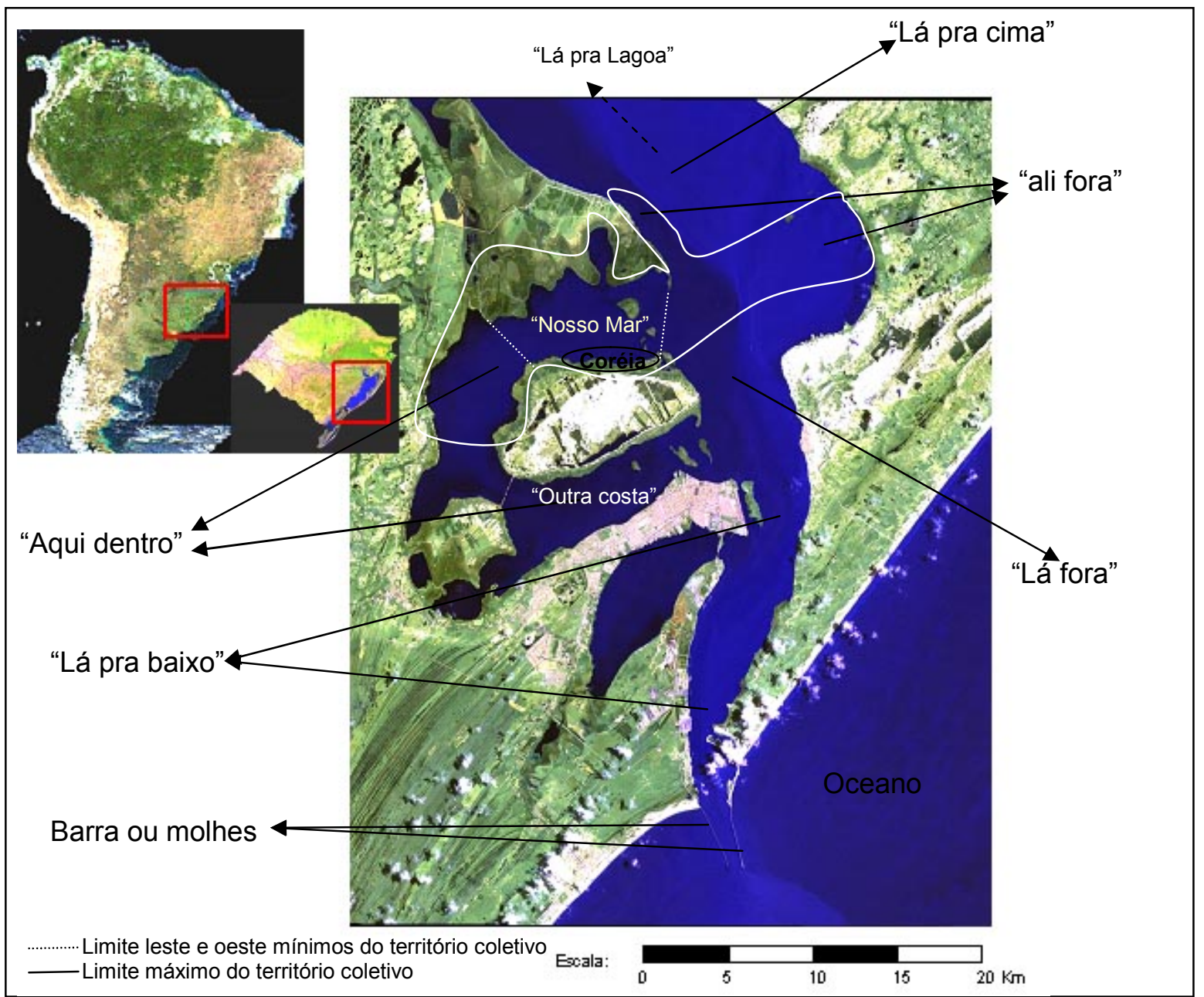

Figura 4: Mapa vernacular da ordenação do mundo "fora" do território Coreano.

As massas de água são categorizadas em pares que se opõem: a água doce ('é um horror' porque 'num produz nada, num produz peixe nenhum') e a água salgada ('a

\footnotetext{
${ }^{103}$ Dentro da categoria "lá pra Lagoa" ou "lá pra Porto Alegre", os pescadores agregam a influência de todas as bacias hidrográficas que constituem o complexo da Lagoa dos Patos ao norte do rio São Gonçalo: a do Jacuí/Taquari, do Caí, dos Sinos, do Gravataí, do Velhaco, do Camaquã e do Litoral. Curiosamente, no entanto, o Lago Guaíba e seus afluentes (sobretudo os da bacia hidrográfica do Jacuí/Taquari) são os que mais contribuem com descargas fluviais ao sistema lagunar, seguido do rio Camaquã (Herz, 1977).

${ }_{104}$ A palavra "peixes" é usada entre aspas, pois, para os pescadores coreanos, crustáceos como o siri e o camarão também são etnotaxonomicamente agrupados como "peixes".
} 
água salgada é uma mãe' porque 'aqui nóis só pesca peixe de água salgada') ${ }^{105}$. A água salgada "vem do oceano" e a água doce "vem lá de cima". Da água doce também se constroí duas categorias: a que "vem de Pelotas", "daquele arroiozinho de Pelotas", “água meia avermelhada", que "é terrível pra nóis" porque "num produz nada, num produz peixe nenhum" e a que "vem de Porto Alegre", a que "vem da Lagoa", que "traz mais peixe", e "água clarinha" como a água salgada ('água clarinha que parece um vidro').

Os peixes, por sua vez, são infundidos na lógica de oposição das águas, visto que "cum a água vem o peixe": o "peixe" vem "cum ponta de água doce" ou "cum ponta de água salgada"106 sendo o primeiro caso só possível quando ele "vem da lagoa" e o segundo, "quando ele vem do oceano". Portanto, o padrão migratório do "peixe" também é uma forçante natural que depende da hidrodinâmica estuarina.

O "peixe" que "vem do oceano" e entra no estuário da Lagoa dos Patos é categorizado como "peixe de entrada" ('dá entrada do oceano'), enquanto que o "peixe" que migra "da Lagoa pro oceano" é o "peixe de arriada" ou "peixe de saída" ("ele sai pro oceano') ou ainda, no caso da tainha, "tainha de corrida".

Uma outra importante categoria de "peixes" são os "peixes de água salgada", que "dá entrada do oceano", e os "de água doce", que "vem desses arroio aí". Em Marques (1991) e Souto (2004) também foram observados nos pescadores estuarinos as categorias "peixe de água doce" e "de água salgada", embora não se saiba se na Bahia é assim categorizado para comunicar a origem.

Além das implicações que o mundo "lá fora" tem "aqui dentro", que permitem uma apropriação destes fenômenos "aqui dentro", a geração de conhecimentos acerca do mundo "lá fora" atende ainda a outros mecanismos: experiências pontuais (por alguma necessidade e/ou oportunidade de pescar em outros locais), experiência

\footnotetext{
${ }^{105}$ Quando os nativos coreanos dizem que pescam "peixe de água salgada", não quer dizer que eles não pesquem peixes que tenham tolerância a baixas salinidades como a tainha ou estuarino-residentes, como o peixe-rei, mas que eles não pescam peixes que são exclusivos de água doce como a traíra (Hoplias malabaricus) e o jundiá (Rhamplia sp).

${ }^{106}$ As "pontas de água" equivalem a Zona de Mistura estuariana (ZM): "o peixe tumbém gosta de uma água meia misturada, nem muito doce e nem muito salgada, uma água meia misturada... de pontas d'água, né, pontas d'água" (Guega, 54 anos, pescador artesanal). Dependendo de qual for a massa de água intrusante (água doce das descargas fluviais ou salgada do oceano), passa-se do termo geral ("pontas de água') a um mais específico ('pontas de água doce' ou 'pontas de água salgada').
} 
recorrente (viagens regulares para as regiões de borda em função de 'safras ${ }^{\text {,107 }}$ permite contato com o ambiente e com pescadores além borda), informações advindas de outras comunidades (há a difusão de informações como uma forma de cooperação intercomunitária, seja por via do rádio, telefone celular e/ou pessoalmente ${ }^{108}$ ) e por origem (alguns habitantes coreanos originários de outras comunidades pesqueiras passam a habitar a Coréia por meio de casamentos exogâmicos ${ }^{109}$ ). Em qualquer um destes casos, no entanto, o conhecimento gerado é pautado sob a lógica das tradições pesqueiras da Coréia.

Portanto, na Coréia, a ordenação do mundo "lá fora" é feita em relação ao mundo "aqui dentro" (origem das massas de água e abundância e tipo de pescado, entrada e saída de peixes, diferenças do mundo natural e social de 'aqui dentro' X 'lá fora'). Segundo Elíade (1992), para os povos “primitivos”, “o 'verdadeiro mundo’ [o 'nosso mundo'] se encontra sempre no meio, no centro...", é a lógica através da qual se torna possível uma orientação. Pode-se dizer, portanto, conforme Ruddle (2000), que o conhecimento tradicional é local porque ele emerge e se reproduz em contextos sociais específicos. No caso da Coréia, o conhecimento tradicional emerge de uma comunidade que tradicionalmente pesca em uma zona baixa, o Saco do Arraial. É o mundo "aqui dentro", território fundado sob uma lógica, que é tomado como referência para análises do mundo "lá fora".

Quando se fala em território coreano, é a uma pequena porção do espaço aquático situado no interior do Saco do Arraial a que se refere: o "nosso mar" (Figura 2 e 4). O espaço físico (bancos de areia, pontas de bancos de areia, plantas aquáticas e de marismas, pequenas ilhas, caminhos de navegação, fundos lamosos, ondulações da água, peixes, ventos, luas, estrelas, etc) densamente nomeado (Figura 2) denuncia a ocupação remota do lugar apesar da emergência recente da Coréia ('Num é uma comunidade nova, é herância e herância. É um tronco que vai longe’ Guega, 54 anos, pescador artesanal) ${ }^{110}$. Souto (2004) através de um mapa vernacular identifca várias toponímias nas áreas de pesca em Acupe (BA). Segundo Nietschmann (1989), as

\footnotetext{
${ }^{107}$ Souto (2004) também observou a utilização do termo "safras de..." para se referir ao tempo em que se inicia e termina a pesca de determinado recurso pesqueiro.

108 Mauss (2003) ressalta o conhecimento tradicional de lugares "extremamente distantes" numa sociedade esquimó de caçadores e pescadores, mesmo entre aqueles que lá não estiveram, devido à difusão de informações entre os esquimós.

109 Adomilli $(2002$; 2007) documentou a existência de casamentos exogâmicos na pesca da Lagoa do Peixe (RS) e de São José do Norte (RS), respectivamente.

${ }^{110}$ Sobre as origens da ocupação da Ilha dos Marinheiros e da Coréia, ver item 3.3.
} 
toponímias mantêm a inteligibilidade de tempos de ocupação e posse que se imbricam e se engendram historicamente na construção de um território.

O "nosso mar" é limítrofe ao norte às terras de outra ilha, a Ilha da Torotama, e ao sul ele se encontra com as terras dos pescadores coreanos (Figura 2 e 4 ) e, neste último caso, merece algumas considerações. Como a especialização na pesca artesanal é um processo recente na Coréia, na percepção da terra e do mar ainda persiste a contiguidade terra-“mar" apontado por Diegues (1983) para pescadores-agricultores em geral $^{111}$. Isso implica que o proprietário das terras adjacentes à encosta possui direito de uso exclusivo do local ('praia de fulano' ou 'porto de ciclano'), bem como de um "trecho de água" bem raso adjacente à encosta chamado por eles de "aqui no seco", "o seco da croa" ou "costão". "O seco da croa" em geral usado para atracar o "caíco", limpar o "bote"112, desmalhar peixes e atracar o "bote" nas "balizas"113, onde se dá o limite mais externo de propriedade individual. Normalmente, no entanto, esta região da encosta não é utilizada individualmente, mas compartilhada entre vários membros da comunidade com quem se tem mais afinidade. Se pessoas de outras comunidades quiserem fazer uso deste local têm que se pedir permissão, o que por vezes é concedido sob a forma de trocas de favores ou não.

Não só as encostas são de direito individual, mas utilizado coletivamente, como também os "valos" e a "rua do porto" (Figura 5). A "rua do porto" é um caminho da terra para a "praia" (ou "porto') sempre paralela ao "valo" e o "valo" é um canal construído por ação antrópica ${ }^{114}$ que geralmente é de água doce e mantém contato com a água do estuário. No "valo", os "botes" e os "caícos" de várias pessoas da comunidade são guardados segundo a permissão do proprietário da terra. A "rua do porto" é usada para leva-e-traz dos petrechos de pesca do bote e/ou caíco para terra. Neste sentido, a

\footnotetext{
${ }^{111}$ Segundo Diegues (1983: 151), uma das características dos pescadores-lavradores é a percepção do "mar fazendo parte da terra" e as implicações da especialização na pesca artesanal é a percepção do mar como entidade própria, embora não oposto a terra. Como a especialização em pescadores artesanais na Coréia remonta a década de 1940-50, a percepção do mar como uma entidade própria ainda não se consolidou.

${ }^{112}$ Os "caícos" são embarcações movidas a remo com aproximadamente $3 \mathrm{~m}$ de comprimento em média. Já os "botes" são motorizados, porém de baixa autonomia, com 5 a 10 metros de comprimento (HAIMOVICI et al, 2006).

${ }_{113} \mathrm{O}$ "bote" é amarrado à "baliza", pedaço de tronco fincado no fundo da coluna de água.

114 Atualmente estes valos são feitos e mantidos com tratores da prefeitura, mas inicialmente, antes da abolição da escravatura, os habitantes locais afirmam que foram construídas e eram mantidas pelos escravos.
} 
"praia", a "rua do porto" e os "valo"115, os três juntos, podem ser considerados um lugar onde o mundo da terra e do "mar" se encontram e se misturam. A prática da posse coletiva deste lugar permite condições de igualdade no acesso ao "mar" entre os pares. Apesar da posse individual relativamente fixa ${ }^{116}$, entre os usuários há um movimento migratório para o uso de outras "ruas do porto" que são melhores em determinados períodos do ano.

Maldonado (1988) também observa a posse da praia, do espaço da moradia e do mercado, que determinam padrões de herança e outras relações sociais, só que no sentido contrário, do mar para terra. Em várias publicações (CUNHA e ROUGEULLE, 1987; CALVENTE, 1993; RAMALHO, 2006), estes locais em terra de acesso ao mar têm sido apropriado por empreendimentos turísticos. Antes, porém, constituíam importante componente do território de pesca, uma vez que em torno dessa via da terramar se construía um conjunto de relações de uso e de posse dentro do grupo. Em Calvente (1993: 73), no Saco da Capela "criam-se vários territórios: o dos pescadores, o dos banhistas e o dos esportistas" que podem ser observados em terra e no mar.

\footnotetext{
$115 \mathrm{O}$ monitoramento da enchente e da vazante é feito pelo valo, antes de se chegar à praia, e o empilhamento da água no "costão" de uma das ilhas acaba confundindo os pescadores coreanos: "Chega aqui no valo, a água tá correndo pra baixo. Chega lá na praia tá enchendo. A água tá saindo do valo, mas lá tá enchendo. E as veiz a gente sai aqui cum ela enchendo aqui, chega ali fora tá vazando a água" (Sr. Oswaldo, 70 anos, ex-pescador-lavrador).

${ }^{116} \mathrm{O}$ direito de posse se dá mediante a ocupação e/ou compra de terras. Muitas vezes gerações de uma família se estabelecem numa determinada faixa de terra, outras vezes se observa a mudança de famílias para outras faixas de terras dentro desta mesma comunidade. Estas mudanças, no entanto, se dão num intervalo de décadas.
} 


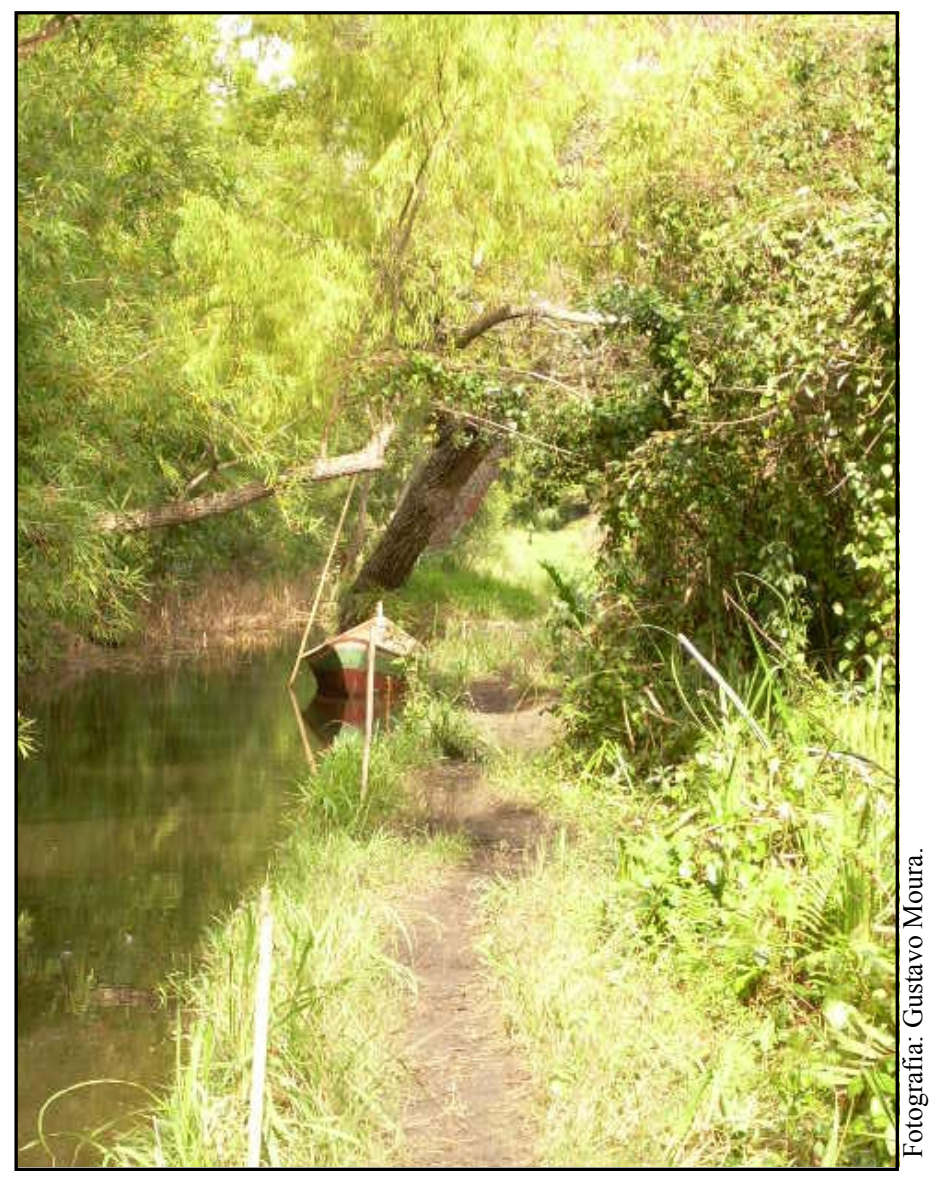

Figura 5: Fotografia do "valo" (à esquerda) e da "rua do porto" (à direita).

Já os limites leste e oeste do território grupal coreano apresentam uma dinâmica diferenciada dos anteriores. Ambos são transições para territórios de pesca de outras comunidades ('lá já é outras pescaria'), o que caracteriza estas fronteiras, segundo Cordell (1983; 1989), como "bordas" ou "zonas tampão"117. A borda oeste do território grupal coreano se dá ainda no interior do Saco do Arraial, onde os referenciais de limite são dois bancos de areia: a "croa do Lúcio" e a "croa Grande" (Figura 2 e 4). Ou seja, a borda é justamente o "trecho de água" de uma a outra "croa", uma é o limite máximo a oeste e a outra é o limite mínimo a leste (ver item 4.2). Além da "croa Grande" "já é outras pescaria" e os coreanos quase nunca pescam ${ }^{118}$.

A partir desta divisão territorial intercomunitária, o "aqui dentro", o interior do Saco do Arraial, é subdividido segundo a lógica coreana, em duas partes: o "nosso mar" e a "outra costa". A “outra costa" seria toda a porção de "mar" do Saco do Arraial, e as terras nas suas adjacências, não apossadas pelos coreanos, ou seja, a "outra costa" é

\footnotetext{
${ }^{117}$ A existência do território coreano não exclui a existência de territórios de pesca de outros grupos, ou até do próprio Estado-nação, que o sobreponham.

${ }^{118}$ Sobre a pesca além da croa Grande ver item 4.5.
} 
tudo o que não é o "nosso mar""119 (Figura 4). Em Papua Nova Guiné, segundo Carrier e Carrier (1989), e na Indonésia, segundo Iwakiri e Mantjoro (1992) também foram verificados a posse de espaços aquáticos nos territórios grupais de pesca a partir das comunidades instaladas em terras adjacentes.

A borda leste é o que se entremeia ao "lá fora" e ao "aqui dentro", o "ali fora" $"$. Esta zona de transição entre o território coreano e "outras pescaria, outros quinhento" está longe de ser uma fronteira fixa, embora demarcada, pois se flexibiliza sazonalmente (ver itens 4.4 e 4.5): “A gente vai ali na Ponta do Mosquito e olha pra Torotama..." (Sr. Dino, pescador artesanal, 67 anos); "Eu pescava bagre lá fora. Já matei aqui também, mas foi meio por causualidade. Na época que dava muito bagre ali fora eu já matei bagre. (...). Essa andana que eu pescava era na croa do Diamante” (Sr. Rui, 60 anos); Eu pescava curvina ali fora na Marambaia, na beira do canal do Diamante ali, na Croa do Diamante ali. (Sindo, pescador artesanal, 40 anos); Onde a água corre mais é ali nas Boca só. (Moisés, pescador artesanal, 43 anos). Um banco de areia, a "croa do Diamante", e os baixios da "Ponta do Mosquito" são os limites máximos da borda leste coreana. O limite mínimo da borda leste coreana é "as Boca", abertura norte do Saco do Arraial cravejada de ilhas (Figura 2 e 3): “As boca ali é a saída, é a saída de nosso mare . É a saída e a entrada" (Guega, 54 anos, pescador artesanal). Vale ressaltar que, ainda que os coreanos migrem regularmente para o corpo estuarino principal, são nos baixios "ali fora” ('Ponta do Mosquito' e 'croa do Diamante') que eles pescam, o que reforça a principal característica da Coréia: a pesca em baixios $^{121}$.

Além da divisão territorial intercomunitária, há divisões sazonais intracomunitárias do território grupal coreano. Novamente é um banco de areia que é tomado como referência: a "croa dos Cavalos""122 (Figura 2). Os moradores a oeste da

\footnotetext{
${ }^{119}$ Sob a égide da oposição binária, em geral, o Saco do Arraial é subdividido em duas categorias pelos coreanos. Há, no entanto, mais uma categoria que acaba sendo incluída na "outra costa": "ali nas bandeirinha", em referência a comunidade das Bandeirinhas da Ilha dos Marinheiros que é adjacente àquele corpo d'água.

${ }^{120}$ Algumas vezes os coreanos se referem ao "ali" como "pra fora", quando se remete a "Ponta do Mosquito" ou à "croa do Diamante".

${ }^{121}$ Ainda que os coreanos só pesquem nos baixios, inclusive "ali fora", há uma certa ordenação da morfologia da borda leste: "croa" (água pelo joelho), "fundo" (um remo de água) e "canal" (até uns 18-20 metros).

${ }^{122}$ A tomada destes referenciais espaciais como delimitação deste território não corrobora teorias de determinismo geográfico. Salienta-se, com veemência, que há aspectos históricos como a imposição de redes fixas para a pesca do camarão (o 'saquinho') que contribuíram irrefutavelmente com maior importância que os aspectos geográficos. No entanto, como o objetivo do trabalho é apenas descritivo
} 
"croa dos Cavalos", com maior frequência, em "safras" de "camarão", pescam a oeste desta croa e os que moram a leste, pescam, sobretudo, a leste. Abolida a safra de camarão, a divisão intracomunitária também se aniquila (ver item 4.5.4). Nas safras de "corvina" e de "bagre" a "croa dos Cavalos" também marca outra divisão: os moradores a oeste da "croa dos Cavalos" dificilmente vão "lá fora" nas safras destes pescados (ver item 4.5.6).

Nietschmann (1989), nas ilhas de Torres Strait, e Iwakiri e Mantjoro (1992), nas Ilhas Ponam, também observaram bordas de territórios de pesca comunitários serem materializadas em recifes de corais e bancos de areia. Segundo o primeiro autor, esta apropriação pelo conhecimento do espaço tridimensional significa uma territorialização, além da superfície aquática, da coluna de água. Na Coréia, como a pesca é realizada numa zona baixa, o Saco do Arraial, além da apropriação da coluna de água, as técnicas de pesca permitem a apropriação do fundo.

Segundo Mircea Elíade (1992), é em torno do eixo cósmico que se estende o "nosso mundo", um universo origina-se a partir de um ponto central: o seu "umbigo". Para o mesmo autor, isso quer dizer que o "nosso mundo", além de uma lógica de orientação, é uma representação do território no centro geográfico. Neste sentido, na Coréia, na medida em que as incursões pesqueiras e relatos foram "lá pra fora" do "nosso mar" a densa trama cognitiva se dissipa numa reafirmação da validade local do conhecimento ecológico tradicional. Portanto, a partir do "Centro do Mundo" se irradia e circunscreve o espaço conhecido, sendo os marcos físicos que estabelecem limites entre as comunidades de pesca fronteiras do conhecimento ecológico tradicional.

Segundo a lógica da oposição binária, as variações na morfologia de fundo são apropriadas na forma de duas categorias: "É assim, tem o lameirão e tem a croa..." (Sr. Zé, pescador artesanal aposentado, 70 anos). O "lameirão" ou "o mol" seria a região mais funda e as "croa" seriam os bancos de areia, portanto, regiões mais rasas (Figura 2). Ambos são densamente conhecidos e nomeados ilustrando a suma importância de cada um para a tomada de decisões na pesca e fundação de pesqueiros (ver itens $4.4 \mathrm{e}$ 4.5). Forman (1970) e Nietschmann (1989) também observaram, em seus locais de

acerca da estruturação do território coreano, perde-se a dimensão histórica da conformação territorial. Por outro lado, também não há um determinismo trazido pelas técnicas de pesca, já que foram observadas pessoas com redes fixas não-raramente ultrapassar a divisão intracomunitária. 
estudo, um conhecimento detalhado do fundo por parte dos pescadores. Segundo este último autor, considera que o conhecimento do fundo é uma forma de territorializá-lo.

Assim como a morfologia de fundo, as correntes estuarinas também são agrupadas em duas categorias: “...a água bota pra corrê ou prum lado ou pro outro: ou de enchente ou de vazante...”. As correntes de enchente e de vazante constituem fatores de análise imprescindível à pesca e, por isso, é dada uma atenção quase obsessiva por parte dos coreanos: vai-se à "praia" monitorar as correntes até três vezes ao dia mesmo que não se vá ao "mar". Quando não se dá a devida atenção, o insucesso na pescaria já começa numa dificuldade desnecessária da retirada das embarcações do "valo".

As correntes estuarinas são tão importantes nas tomadas de decisão que a posição de se "botá as rede" é categorizada em função das correntes de água: "ao correr (da água)" (duas pontas da rede em posição paralela à corrente d'água) ${ }^{123}$ e "no correr", "na feição" "124, "embocado na água", "na correnteza" ou "atravessado" (duas pontas da rede em posição perpendicular a corrente d'água) ${ }^{125}$ (Figura 6). Souto (2004) notou que em Acupe (BA) as correntes de enchente e de vazante estuarinas se desdobram em várias categorias de "marés" e que cada uma delas requer um tipo específico de petrecho de pesca.

\begin{tabular}{|l|l|}
\hline Correnteza & Rede "atravessado" \\
\hline $\begin{array}{l}\text { Figura 6: Desenho esquemático do posicionamento das redes em função das correntes } \\
\text { estuarinas. }\end{array}$ \\
\hline
\end{tabular}

Outro fator ambiental profundamente conhecido para a apropriação do espaço e para as tomadas de decisões são os ventos. A partir da importância percebida dos ventos na hidrodinâmica estuarina do "nosso mar" surgem categorizações complexas. Para os ilhéus-coreanos o "tempo anda sempre na volta" se referindo ao movimento sempre no

\footnotetext{
${ }^{123}$ Para as redes de camarão, a denominação mais comum para este posicionamento é "de boca pra terra" (abertura da rede em direção a Ilha dos Marinheiros) e "de boca pra fora" (abertura da rede em direção ao 'mar').

124 "Feição" significa a direção da correnteza da água, enchente e vazante. Para alguns pescadores, no entanto, extensa minoria, a "feição" só inclui o sentido da corrente de vazante.

${ }^{125}$ Parte das explicações sobre a divisão de massas de água na borda oeste como referência de fronteira se deve às implicações no posicionamento das redes e nas tomadas de decisão na pesca.
} 
sentido anti-horário do giro do vento ${ }^{126}$. Em função do giro, duas categorias ocorrem: "ventos de cima" (O, SO, S e SE), porque giram "(lá) pra cima” em sentido anti-horário, e "ventos de baixo" (L, NE, N e NO), porque giram "(lá) pra baixo" em sentido antihorário (Figura 7B). Se, no entanto, o giro se der no sentido horário fala-se de "Tempo loco":

É difícil tu vê um tempo voltá. Aqui não! Só aqueles tempo louco sabe. (...). Brrrrammm, pra cá (direção norte) trovoada, né. Vem pra cá (oeste) o tempo, daqui a pouco brrraaammm pra cá (direção norte) de novo. (...). Que eles trato de tempo louco, né, porque ele num tem rumo certo. (Moisés, 45 anos, pescador artesanal).

Os "ventos de cima" e os "ventos de baixo", frequentemente, são evocados a partir dos dois ventos predominantes de cada categoria durante o ciclo anual: o nordeste (NE) e o "rebojo" (SO e O $)^{127}$. Dentro desta categorização, de acordo com sua intensidade, permanência, chuvas, temperatura e origem, os ventos podem ser:

1. Renomeados: ventos que sopram "lá de fora" (origem) são batizados de "ventos de fora", NE e L ('éste'), o SO quando marca a entrada do inverno com contraste de temperatura, do calor para o frio, pode ser chamado de "minuano" e o SE ('su-éste') quando é acompanhado de chuvas e frio (temperatura) no inverno é chamado de "invernada";

2. Superlativados: o nome de um vento no aumentativo ou, por oposição, no diminutivo se refere à alta ou à baixa intensidade, respectivamente;

3. Adjetivados: "aragem de (nome do vento)" é considerado um vento fraco (intensidade) ou, por oposição, "brisa de (nome do vento)" se refere a vento que permanece alguns dias e a ventos intensos;

4. Segmentados: o rebojo pode ser "rebojo flanco" e "do canto" de acordo com sua origem: oeste ou sudoeste, respectivamente.

$\mathrm{Na}$ literatura etnocientífica, vários trabalhos (MARANHÃO, 1975; NIETSCHMANN, 1989; CARDOSO, 2001; OLIVEIRA JÚNIOR, 2003) registraram um conhecimento intenso do regime de ventos pelos pescadores na apropriação do

\footnotetext{
${ }^{126}$ Cardoso (2001) registra a apropriação do giro anti-horário dos ventos entre os pescadores do estado de São Paulo.

${ }^{127}$ Segundo a bibliografia científica, os ventos mais frequentes em ordem de ocorrência são NE, N, L, SO, SE, S e NO (SIQUEIRA e KRUSCHE, 2000). Para efeito de observância da frequência anual do vento "rebojo" deve-se somar as médias anuais dos ventos SO e $\mathrm{O}$, o que nos dá a segunda maior frequência anual.
} 
espaço. Curiosamente, entre estes autores, Nietschmann (1989) também registra a oposição binária de dois ventos predominantes entre os ilhéus de Torres Strait, o NO e o SE.

A Lua é uma forçante natural que influencia as correntes diárias e quinzenalmente, o que gera diversas categorias. As primeiras são categorizadas de acordo com sua entrada e saída da terra, "Lua de entrada" e "de saída", respectivamente, e as segundas de acordo com sua influência nas correntes, Lua cheia e nova, que consolidam tendências de predominância de determinadas correntes, e Lua crescente e minguante que geram tendências de predominância de correntes. A oposição entre as marés de sigízia, entre as marés de quadratura e entre as Luas que aparecem no céu diariamente também foi documentada por Nietschmann (1989).

Um outro "espaço" conhecido que compõe o território coreano são as vegetações aquáticas chamadas de "lixo". Existem duas categorias gerais de lixo: o "lixo bom" e o "lixo ruim". Dentro da categoria "lixo bom", encontra-se apenas um tipo de "lixo", o "lixo-capim" (Ruppia maritima). O "lixo-capim" "dá por cima das croa" e "pegado no chão", é habitado por peixes ('o peixe gosta de lixo-capim') e visitado por pássaros, além de "clariá ${ }^{128}$ as rede" dos pescadores, e, por isso, é "bom" para a pescaria e, consequentemente, associado a um "tempo de fartura".

Já o "lixo ruim" tem "várias qualidades de lixo": o "lixo-gosma", o "lixo-fita", "borra", "lixo-lã", "lixo-funcho", "limo", etc. É interessante observar que nem todos conhecem e comungam da mesma identificação para estes "lixos" surgindo polêmicas quanto a denominação e até da existência de alguns "lixos". Consenso, no entanto, é que nesta categoria de "lixo" nenhum deles "presta" para a pesca, porque "anda boiado" ou "de rolo pelo chão" e "chapa" ou "atola as rede" impedindo a pesca ${ }^{129}$. A existência de "lixos" que destróem as redes de pesca também foi documentado por Adomilli (2002) em comunidades de pesca da Lagoa do Peixe $(\mathrm{RS})^{130}$.

Os "peixes" também são "espaços" profundamente conhecidos e categorizados “aqui dentro". Entre as categorias está uma variação do "peixe de entrada" e "de saída"

\footnotetext{
128 "Clariá" = Limpar.

129 Os "lixos ruins" são restos vegetais que aparecem em grande quantidade no estuário da Lagoa dos Patos e que se entrelaçam em grande quantidade nas redes ('chapa' ou 'atola') dos pescadores destruindoas.

${ }^{130}$ A categoria "lixos" observada por Adomilli (2002), no entanto, não inclui a Ruppia marítima, mas a pedaços de pau, a juncos e a outras plantas. A Ruppia recebe outro nome: "grama".
} 
do estuário: o "peixe de entrada" e "de saída" do Saco do Arraial ${ }^{131}$ ("A gente num tem boca? [...]. É as boca ali mesmo: entra camarão, sai camarão, entra tainha, sai tainha...'. Guega, pescador artesanal, 54 anos). Neste sentido, a partir da entrada e da saída de peixes "das boca", limite mínimo da borda leste do território coreano, eles são categorizados como "de entrada" e "de saída". Portanto, estas categorias surgem de acordo com sua "entrada" e "saída" do "nosso mar", independente se o "peixe" é "de entrada" ou "de saída" do estuário.

Como foi visto anteriormente, a atividade pesqueira coreana está ligada a "peixe de água salgada", dentre as quais a "corvina" (Micropogonias furnieri), o "bagre" (Netuma barba), o "siri” (Callinectes sapidus), a "tainha" (Mugil platanus), o "peixe-rei" (Odontesthes argentinensis), o "camarão" (Farfantepenaeus paulensis), o "linguado" (Paralichthys orbignyanus). Destas espécies, somente a corvina e o bagre se pescam quase exclusivamente "ali fora" e o siri, peixe-rei e o linguado se pescam exclusivamente "aqui dentro". Os "peixes de água doce" são, sobretudo, a "traíra" (Hoplias malabaricus) e o "jundiá" (Rhamplia sp). Nas pesquisas feitas no RS nenhuma menciona que os pescadores do estuário da Lagoa dos Patos utilizam-se de recursos de água doce, com exceção da pesquisa de Pasquotto (2005) com os pescadores de São Lourenço do Sul.

Porém, de todas estas espécies, com exceção do bagre, todo o Saco do Arraial, incluindo o território coreano, é considerado pelos próprios pescadores como "criador do bixo", ou seja, usando a linguagem científica é a zona de criação ou "berçário"132:

\footnotetext{
...o camarão produz muito aqui dentro, entendesse. Aqui eu acho que aqui era pra sê mais preservado. (Sindo, pescador artesanal, 40 anos).

Aqui é o criador do bixo. (...). O nosso mar aqui é criador de tudo cara: de linguado, de peixe-rei, de tainha, de cascote, o cascote é o mesmo que a curvina no caso, né, cria o cascotinho pra virá curvina... (Moisés, pescador artesanal, 43 anos).
}

Dá muita entrada de siri do oceano também, mas também se ele criá aqui ele também faz a desova: ele cria e se apronta aqui pra criação. (Sr. Rui, pescador artesanal, 60 anos).

\footnotetext{
131 Além do mundo "lá pra fora" ser apropriado a partir da lógica que funda o "nosso mar", como foi discutido anteriormente, as categorias criadas na apropriação do mundo "aqui dentro" também tomam ele como referência ('peixe de entrada' e 'de saída', 'Lua de entrada' e 'de saída', o 'tempo anda na volta', 'vento de fora', etc).

${ }^{132}$ Enquanto as zonas rasas do estuário são consideradas "criador" pelos pescadores, "lá pra fora", na zona de canal, e "ali fora" são consideradas zonas de passagem do "peixe".
} 
A idéia do território como área de "criação" traz profundas implicações na atividade pesqueira, que serão descritas ao longo dos próximos sub-itens. O tamanho do "peixe" pescado, o calendário de pesca, as técnicas de pesca utilizadas são diversas se comparadas às pescarias das comunidades da zona de canal estuarino, considerado área de passagem do "peixe", incluindo a borda leste do território coreano. O "peixe" é menor, portanto, a malha das redes também, o calendário mais precoce, as técnicas de pesca mais simples, menores e aparentemente mais diversificadas. Em algumas publicações, observa-se que os baixios dentro de um território de pesca mais amplo geralmente são áreas de não-pesca, pois são considerados santuários pelos pescadores, como no caso de James Bay Cree (WILSON et al, 1994). No entanto, o caso da Coréia é um tanto peculiar, pois o território se encontra dentro de um baixio, o Saco do Arraial, tendo apenas uma das bordas, a leste, no corpo principal estuarino.

No território coreano há locais em que a água "corre menos" ou de "água mais parada" ('Saco do Boto' e o 'Saco da Pinguela'), devido à presença de grandes bancos de areia ao redor, e que "corre mais" ('As Boca'). As de “água mais parada” são consideradas o criador dentro do criador e, por isso, surgiam até recentemente histórias de "Bola de fogo" e de "Boitatá", 133. Hoje, apenas um arroio, o "arroio da Pinguela", é povoado por estas entidades (Figura 2). Neste sentido, o território na Coréia não é homogêneo, pois apresenta rupturas, como Elíade (1992) ressalta como regra tradicional na apropriação de espaços territorializados.

Há ainda uma infinitude dos referenciais espaciais que são apropriados segundo a lógica binária: "noites de Lua" e "noites sem Lua", "boca da noite" e "barras do dia", "inverno" e "verão", "represo de água doce" e "represo de água salgada", "calmaria" e "tempestade", etc. Não cabe aqui falar de todos, já que eles irão emergindo na medida em que se constrói a estrutura cognitiva dos nativos nos itens subsequentes.

Os ventos, as correntes, a Lua, os peixes, a morfologia de fundo, as zonas de transição da terra para o mar, etc. transpõe a unidade espacial apropriada do espaço aquático tridimensional, ou seja, a unidade espacial apropriada corresponde aos compartimentos terra-mar-céu, em consonância ao observado por Cunha $(1987 ; 2007)$. Segundo Cordell, na medida em que estes espaços são classificados e pensados contribui para a delimitação do mar, o que de fato acontece na Coréia. Neste sentido,

\footnotetext{
${ }^{133}$ O Saco do Boto e o Arroio da Pinguela, locais de "água mais parada", foram pintadas de cor diferente do resto do "nosso mar" pelos pescadores no mapa cognitivo (Figura 2).
} 
pode-se dizer, a partir de Maldonado (1993), que o território é conhecimento à medida que viabiliza representações que cada grupo faz da instância natural que explora.

Devido outras comunidades, sobretudo os "das vila"134, não compartilhar da mesma ética de respeito com relação ao que os coreanos entendem como o "nosso mar", no uso de técnicas de pesca consideradas inapropriadas, na pesca em períodos considerados não-ideais e em locais considerados "criador" dentro do "criador", como o "Saco do Boto" e o "Saco da Pinguela", alguns coreanos também acabam reproduzindo o ato recriminado ('Eu vô ajudá a destruí! Vô ficá aqui chupando o dedo, assistindo eles destruí tudo, enquanto eles ganham dinheiro!? Não, eu vô também...'). Por isso, apenas a passagem de qualquer embarcação "das vila” em território coreano já é motivo de grande tensão. Neste sentido, as diferenças de concepção do mesmo espaço por diferentes comunidades fazem com que a ética fundamentada no respeito passe a ser fundamentada na competição, tanto na disputa presencial pelo recurso quanto na manutenção do segredo. Em Iwaquiri e Mantjoro (1992) também se observa conflitos entre comunidades de pesca pela sobreposição de territórios de pesca causados por intervenção governamental e pelo abandono de técnicas de pesca tradicionais.

Outro conflito devido à desarticulação da ética do respeito no uso de recursos territoriais ocorre com a pesca industrial. Mesmo ocorrendo no oceano e, portanto, distante das águas da Coréia, o conflito territorial se instala devido a corvina e o bagre serem capturados antes de sua entrada no estuário por barcos industriais, as "traineiras". Neste sentido, a espera pelo "peixe" muitas vezes é frustrada afetando o ritmo territorial coreano em suas dimensões sócio-econômico e cultural. Os conflitos entre pescadores estuarinos e embarcações industriais no RS é largamente documentada em Kalikoski (2002), Pasquotto (2005), Kalikoski e Vasconcellos (2006), Haimovici et al (2006) e Adomilli (2007).

Intercomunitariamente, a difusão de informações desempenha um papel importante de cooperação e de competição. A obtenção de informações de outras comunidades pesqueiras é indispensável para o movimento dos coreanos para a sua borda leste nas safras de camarão, corvina, bagre e tainha assim como é de grande importância para que outras comunidades se façam presentes em território coreano. Por outro lado, muitas vezes as informações são fornecidas de forma vaga, desencontrada e

\footnotetext{
134 "As vila" são os bairros da periferia da cidade do Rio Grande formados por pescadores, como o Bosque, o Prado e o São Miguel.
} 
até mentirosa. Ademais, os grandes desarticuladores dos segredos intercomunitários através da difusão indiscriminada de informações são os atravessadores (ver item 4.5).

Assim, o "nosso mar" não é construído apenas pelo conhecimento, mas também por outras relações sociais como a ética do segredo, respeito e competição que estão incorporadas na estrutura territorial do grupo. Neste sentido, Acheson e Wilson (1996) afirmam que as regras estruturadas na cultura tradicional de um grupo social local só podem ser aplicadas com vias de sucesso dentro dos limites territoriais deste grupo.

Portanto, Berkes (1999) arrebata: as tradições, e o conhecimento por ela gerado, são duradouras adaptações, mas a lugares específicos. Assim emerge as águas da Coréia, território onde o conhecimento tradicional coreano é produzido e reproduzido.

A partir desta ordenação preliminar dá-se as principais categorias do territorio grupal para a construção da dinâmica etnooceanográfica na pesca. Os principais compartimentos ambientais apropriados ('céu', 'mar' e 'terra') e as categorias geradas estão consoantes aos apontados pela literatura científica. Passo-a-passo estas categorias irão construir as tomadas de decisões na pesca. Em decorrência da perspectiva etnooceanográfica, em 4.2, o enfoque na interação entre os componentes abióticos dos compartimentos "mar" e "céu" construirão a hidrodinâmica estuarina que, em seguida, serão contextualizados no tempo estuarino (etnocronologia estuarina).

\subsection{A hidrodinâmica do nosso mar: "Porque aqui a água corre assim: enchente e vazante...".}

Dada a importância da enchente e da vazante para as tomadas de decisões nas pescarias em território coreano, neste capítulo propõe-se tecer o conhecimento tradicional da hidrodinâmica do "nosso mar" segundo o homem coreano. Numa perspectiva etnooceanográfica, as informações foram obtidas, sistematizadas e detalhadas a partir da pergunta chave deste sub-item: “Quando a água 'corre' de enchente e de vazante ‘aqui dentro'?’. Duas, e não apenas uma, respostas foram obtidas. 
A primeira é uma espécie de convenção, uma definição, o que é considerado enchente e vazante:

Olha, fizesse uma pergunta fácil de respondê e até difícil no seguinte: ela enche correndo pra cá (oeste) e vaza correndo pra lá (leste) (...). Agora, num sei se é assim que tu qué sabê ou se qué sabê devido o vento, Lua ou essas coisa assim. (Sr. Zezinho, 60 anos, pescador-agricultor).

As correntes de sentido oeste seriam as de enchente e as de leste as de vazante (Figura 7A). A convenção, no entanto, gerou uma suspeita de encontro e separação de águas no interior do Saco do Arraial, pois, além da mesma convenção ser tomada para o "nosso mar" e para a "outra costa", seus gestos apontando o sentido leste e oeste remete tanto ao "nosso mar" quanto à "outra costa" em sentido de vazante ou de enchente ao mesmo tempo. Esta hipótese foi confirmada por eles:

Deixa eu te explicar mais direitinho: é tipo um balão, vamo supor um balão cum duas boca. Tu assopra numa eu assopro noutra, entendes, e o nosso ar vai se batê lá no fundo do balão. Então ela tem duas entrada e duas saída: quando ela enche, ela enche por lá e enche por aqui. Aí ela tem que batê, em algum lugá ela tem que bate, né. E quando ela vaza, ela tem o mesmo esquema (...). Então forma por cima d'água tipo um risco, um risco assim duma água meia gozada, né, meia tremida. Ali é a divisão, que ela começa a corrê prum lado e outra parte d'água pro outro. É uma divisão que tem ali, né. (...) que tem essa saída aquí das Boca e tem a saída lá das Pomba, lá que é na beira do cais, lá do mercado. (...). Mas a gente sabe que aquilo ali é uma correnteza que num tem vazão pra outro lado: aonde ela enche é aonde ela vai saí. Só que a Ilha fica no meio e elas faz essa divisão. (Guega, 54 anos, pescador artesanal).

Segundo os pescadores, ao mesmo tempo, seria possível a ocorrência de correntes de enchente ou de vazante tanto na entrada Sul do Saco do Arraial ('das Pomba') quanto na entrada norte ('as Boca') ('Então ela tem duas entrada e duas saída: quando ela enche, ela enche por lá e enche por aqui. [...]. E quando ela vaza, ela tem o mesmo esquema'). O encontro, sob o regime de enchente, e a separação, sob o regime de vazante, de massas de água ocorre no interior do Saco do Arraial ('...é tipo um balão, vamo supor um balão cum duas boca. Tu assopra numa eu assopro noutra, entendes, e o nosso ar vai se batê lá no fundo do balão. [...].Então forma por cima d'água tipo um risco, um risco assim duma água meia gozada, né, meia tremida. Ali é a divisão, que ela começa a corrê prum lado e outra parte d'água pro outro'). Vale ressaltar que é esta divisão de águas e a sua variação sazonal e anual que marca o limite oeste do território coreano próximo à "croa Grande". 
Além de confirmar a divisão de águas no Saco do Arraial, há fortes indícios de um outro padrão de circulação no interior do Saco do Arraial em função da presença ou não de água doce ${ }^{135}$, ou seja, da descarga fluvial ('Quando ela tá doce não, ela vai se encontrá lá fora' Sr. Dino, 61 anos, pescador artesanal). Estes indícios, por sua vez, dialogam com os dados da segunda resposta.

Já a segunda resposta à pergunta chave corresponde às ocasiões (causa-efeito) em que a enchente e a vazante ocorrem:

O qué que faz é o vento: quando o vento é de cima ela vai enchê, quando o vento vira pra baixo ela já vaza. Se tem água lá pra cima ela vai tê que vazá também, aí ela vaza sempre, né. Se chove lá pra cima, a água vem de cima e passa pra cá, aí só vaza, aí num enche. Quando tem água e dá o rebojo aí ela enche, aí ela represa. Quando ela vem, ela vem direto, vem arrasando tudo, aí ela vaza sempre. Mas se vim esses vento de cima, aí ela enche, aí ela represa. (Sr. Dino, 61 anos, pescador artesanal).

É o vento, né, é o vento que manda, aqui dentro é o vento. Quanto mais rebojo, mais ela vaza. Mais nordeste, mais ela vaza também. E o vento sul é pra enchê. Vento sul, su-este, aí ela enche. Ou senão cum mal tempo, né, aí pode sê qualqué vento. Aí ela mete memo um bucado pra dentro. Mas aí é marcando tempo, né. Basta o cara vê, quando diz assim: 'Porra, a água tá criando na praia que é um horror, tá enchendo'. Mal tempo em cima. E logo em seguida dá memo. Quando chove lá pra cima e dá vento nordeste, ah, não, aí ela corre pra dentro aí. Ela prensa aí fora, né, fica prensada ali fora. Aí, em vez de despejá, ela entra praí. Quando chove lá pra cima e dá vento sul ou sueste, claro, aí cresce. Entra aí. Dá represo, né. Aí é o represo que chama, represo d'água. É o que nóis chama aqui o represo. (Gordo, 39 anos, pescador artesanal).

Quase sempre vaza a água cum nordeste. É difícil enchê. Quase sempre tá de vazante. Só quando tá ameaçando tempo ruim que aí dá represo, né, aí ela... aí ela enche. Quando se prepara rebojo, um tempo, né (...). Mai o normal mesmo é vazá. Quando tá ameaçando tempo, que o tempo tá ruim, aí ela vira na enchente. Mas é cum rebojo e sul, né. Quando vem lá de cima, é água doce que vem, né, tempo de chuva, que chove muito, né. Aí vem água doce. Aí num tem vento que freie ela. Aí cum nordeste é pior ainda (...) faz a volta toda. Isso daí depende do clima e da chuva, né... (Delso, 44 anos, pescador artesanal).

De acordo com as respostas, são duas as forçantes que causam a enchente e a vazante no nosso mar: o vento ('é o vento, né') e as chuvas associadas às descargas fluviais ('Se chove lá pra cima'; 'Quando chove lá pra cima'; 'Quando vem lá de cima, é água doce que vem'), necessariamente nesta ordem. A ordem de importância é definida por frases como "O qué que faz é os vento...", “o vento é que manda..." ou pela ordem das forçantes na tessitura da resposta ('Quase sempre vaza a água cum

\footnotetext{
${ }^{135}$ A presença de água doce, segundo os pescadores coreanos está associada às chuvas "em Pelotas" e "em Porto Alegre" que geram descargas fluviais "deságua tudo pra nóis aqui".
} 
nordeste'). Adomilli (2002) também observou os ventos como principal forçante na comunicação da Lagoa do Peixe (RS) e o oceano. Almudi (2005), também para a Lagoa do Peixe, atribui importância às chuvas, ainda que mais modesta que a do vento ${ }^{136}$.

São atribuídos os "ventos de cima" (SE, S, SO e O) ou o "rebojo" (SO e O) como causas das correntes de enchente ('quando o vento é de cima ela vai enchê'; 'Só quando tá ameaçando tempo ruim que aí dá represo, né, aí ela... aí ela enche. Quando se prepara rebojo, um tempo, né') e os "ventos de baixo" (NO, N, NE e L) ou o "nordeste" como as das de vazante ('quando o vento vira pra baixo ela já vaza'; 'Quase sempre vaza a água cum nordeste'; 'Mais nordeste, mais ela vaza também') ${ }^{137}$.

O regime de enchente e de vazante gerado pelos ventos, segundo os pescadores, obedece a um mecanismo de interação entre oceano e estuário:

Cum rebojo o oceano cresce e empurra água pra nóis aqui. (...). Alteia lá e bota pra nóis aqui. Cum nordeste ela baixa lá (no oceano) e aperta ela pra outro ponto do oceano, ela vai enchê pra outros ponto do oceano e vaza pra nóis aqui. (Sr. Meca, 68 anos, pescador-lavrador).

Os "ventos de cima" ou o "rebojo" fazem com que "o oceano empurre água pra nóis aqui" ('o oceano tá cheio', 'o oceano cresce na praia') e os "ventos de baixo" ou o nordeste "ela baixa lá e aperta ela pra outro ponto do oceano (...) e vaza pra nóis aqui" ('arrecua o oceano', 'o oceano chupa ela de volta'). Na Lagoa do Peixe (RS), a entrada de água do oceano também é provocada por ventos do quadrante sul, enquanto a saída é gerada pelo vento NE (ADOMILLI, 2002; ALMUDI, 2005).

Porém, quando se acrescenta a forçante "chuvas" (descarga fluvial) uma importante mudança no padrão de circulação em relação ao regime apenas controlado pelos ventos acontece:

É difícil enchê cum nordeste, só tendo muita água doce aí pra cima. Aí cum a força do vento ele empurra água, ela cria ${ }^{138}$ aqui. (Evaldo, 36 anos, pescador artesanal).

\footnotetext{
${ }^{136}$ A Lagoa do Peixe tem disposição geográfica semelhante à Lagoa dos Patos e submetida às mesmas condições climáticas.

${ }^{137} \mathrm{Na}$ explicação do por que uma categoria de ventos produz vazante e outra enchente, o uso de representantes como o "nordeste" e o "rebojo", respectivamente, explica a principal categorização de ventos, em função da frequência, visto no item 4.1, segundo a lógica da oposição binária. Neste caso, as ações que forem atribuídas ao vento "nordeste" e ao vento "rebojo" servem, respectivamente, a todos os "ventos de baixo" e aos "ventos de cima".

138 "criar" = crescer.
} 
Cum qualqué vento ela vem, mas se tivé nordeste aí que ela cresce. Ah, aí é uma loucura cara! Ela entra cum calmaria também: tendo água lá pra cima ela entra sempre, né, cara. Até cum rebojo: é contra pra ela entrá, mas ela cresce cum rebojo também. Quando tem muita água ela vem vindo, vem vindo... mas cum nordeste é que ela vem ligeiro cara. (Sindo, 40 anos, pescador artesanal).

"Se tivé água lá pra cima” propicia-se um regime de enchente ('Ela entra cum calmaria também: tendo água lá pra cima ela entra sempre, né, cara), inclusive com ventos como o "nordeste" que comumente estabelece um regime de vazante ('Cum nordeste enche porque vem cum força d'água'; 'É difícil enchê cum nordeste, só tendo muita água doce aí pra cima'; 'mas cum nordeste é que ela vem ligeiro'). Vale ressaltar que sempre que a água "correr" para oeste ('entra aqui’) o regime de corrente será considerado de enchente para o "nosso mar", devido à convenção adotada ${ }^{139}$ (Figura 7A). Se o sentido oeste do "correr" da água for acompanhado de uma elevação do nível da água ('Aí cum a força do vento ele empurra a água, ela cria aqui', 'mas se tivé nordeste aí ela cresce'), a certeza da "enchente” ganha força.

Por outro lado, há falas, citadas anteriormente, que parecem dissonantes como a do Sr. Dino ('Quando chove lá pra cima, a água vem de cima e passa pra cá, aí só vaza, aí num enche (...) aí ela vaza sempre’), que se refere a um regime de vazante com a água doce que "vem de cima". Este talvez seja o único caso em que alguns pescadores abolem a convenção de enchente para o "nosso mar", em função do conhecimento do regime de vazante em todo o estuário. Este é o caso em que a "água corre na volta" ou "faz a volta toda", ou seja, há uma circunfluência da água ao redor da Ilha dos Marinheiros ('quando a água tá doce ela se encontra lá fora') com saída pelos molhes da barra para o oceano.

A explicação para o fenômeno perceptivo da convenção das correntes de enchente e de vazante tem bases no conhecimento do território, discutido em 4.1, ou, dito de outro modo, nos limites territoriais do conhecimento tradicional: como os limites do território coreano não atingem todo o Saco do Arraial, o monitoramento da enchente e da vazante estuarina é feito segundo a dinâmica da água do "nosso mar", o "Centro do Mundo", que é uma parte do Saco do Arraial.

\footnotetext{
139 Vale ressaltar que o conhecimento científico, embora no contexto de compartimentalização do conhecimento, adotou as mesmas convenções de enchente e de vazante para o Saco do Arraial do conhecimento tradicional, sem o conhecê-lo, que se diferenciam do regime de enchente e de vazante adotado para o estuário. Em seu trabalho sobre a hidrodinâmica do Saco do Arraial, Giordano et al (2007: 3) observou dois padrões de circulação em função da ocorrência sazonal de chuvas: "fluxo de enchente através das duas aberturas" e "enchente na sua abertura norte e vazante na sua abertura sul".
} 
Ainda que menos frequente e pouco conhecido ${ }^{140}$, ocorre um terceiro padrão de circulação:

\begin{abstract}
Já aconteceu até o contrário: dela salgá por lá (outra costa). Esgota aqui a água doce, a água baixa, e ela vim salgando por lá também. Não muita força de água doce, né. Precisa tá bem baixa pra ela salgá, pra água misturá bem. (...). Ela vai entrando ali pelo canal da cidade e se vai a água salgada. Já por aqui não: dá de cara cum a doce aí fora, já custa mais. (Delso, 40 anos, pescador artesanal).
\end{abstract}

As correntes de enchente de água salgada ocorre somente através da face sul da Ilha dos Marinheiros ('das Pomba' ou 'outra costa') e sua saída pela face norte (Figura 7C). Para ocorrer este padrão de circulação é necessária a confluência de dois fatores: a existência de pouca “força de água doce” (por isso a água 'baixa') ('Não muita força de água doce, né’) e a entrada de água salgada somente pela face sul ('Ela vai entrando ali pelo canal da cidade e se vai a água salgada. Já por aqui não: dá de cara cum a doce aí fora'). Como resultado, diferente das águas somente doce ou salgada dos dois padrões de circulação anteriores, a água fica "misturada" ('Precisa tá bem baixa pra ela salgá, pra ela misturá bem').

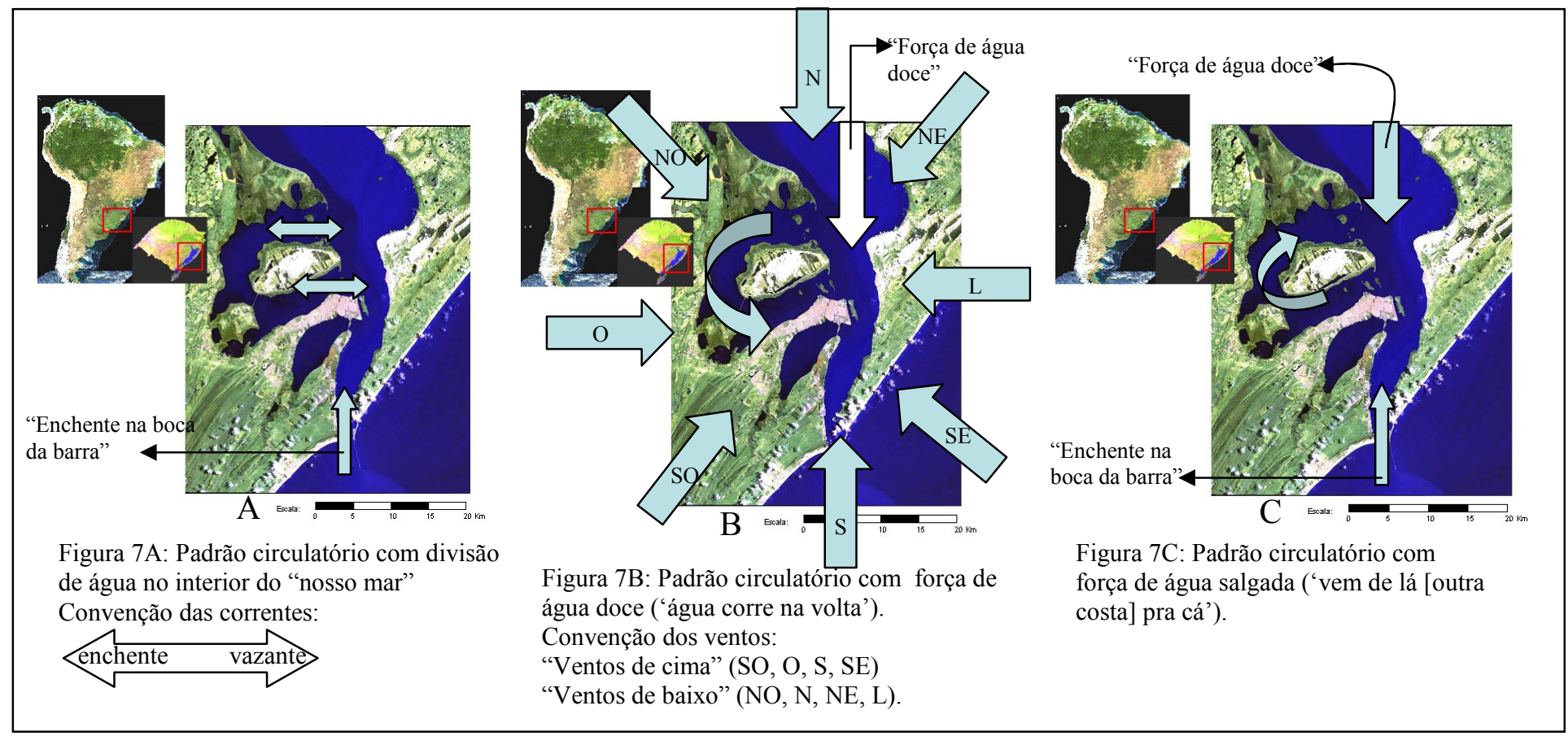

Figura 7: Padrões de circulação da água em "nosso mar".

\footnotetext{
14012 dos 21 pescadores entrevistados disseram não saber sobre esse movimento da água, enquanto que 5 negaram esta possibilidade dizendo que "eu nunca vi". No entanto, em conversas nas "vendas" (bares) esta informação não é incomum entre os pescadores.
} 
Apesar de ser "difícil de enchê cum nordeste", há ainda mais uma situação em que o regime de enchente é estabelecido sob a ação dele:

\begin{abstract}
A água, ela sente a virada de tempo, né, as veiz a gente anda trabalhando e diz: 'ó, vai dá tempo, a água tá enchendo'. (...), o oceano sente, né, a virada de tempo. Sabê quando vai dá rebojo já sabe, que ela represa. Pode tá dando nordeste que ela enche, é porque o tempo puxa, né. Ameaça o tempo, a água represa. (...). A água é assim: ela represa quando o oceano vem pra costa, ela (a água) alteia e é quando ela salga aqui pra nóis. (Sr. Dino, 67 anos, pescador artesanal).
\end{abstract}

Quando a água "tá sentindo mal tempo" um regime de enchente também se estabelece sob a ação do vento nordeste. As águas da Coréia "sente mal tempo" quando "se prepara rebojo", ou seja, a ação do vento "rebojo" é não-local, é no oceano. É "quando o oceano cresce", é "quando o oceano vem pra costa, ela alteia e é quando ela salga aqui pra nóis". Portanto, a ação não-local do vento rebojo provoca um regime de enchente no "nosso mar" ainda que sob a ação local do vento nordeste.

Por outro lado, quando a ação do "rebojo" é local, observa-se efeitos diferentes da ação não-local:

\begin{abstract}
Aí, quando cai o vento rebojo, ela baixa. (...). Tendo muito vento ela baixa bastante. Aí, depois, cumeça a enchê, coisa de cinco-seis hora ela cumeça a enchê. Acho que é a hora que cai o vento, né. O vento é daqui ('rebojo'), tira a água pra fora, né, a força do vento faz a água corrê. (Evaldo, 36 anos, pescador artesanal).
\end{abstract}

"Quando o rebojo cai aqui”, ou seja, a ação-local do vento rebojo produz, sucessivamente, um regime de vazante ('...quando cai o vento rebojo, ela baixa') e, depois, de enchente ('Aí, depois, cumeça a enchê, coisa de cinco-seis hora ela cumeça a enchê').

Neste sentido, pode-se dizer que quando os pescadores agregam o vento "rebojo" nos "ventos de cima", inclusive na sua ação de provocar regimes de enchente e o "represo", desde a segunda resposta a pergunta chave, é da sua ação não-local que eles estão falando: “Quando tem água e dá o rebojo aí ela enche, aí ela represa. Quando ela vem, ela vem direto, vem arrasando tudo, aí ela vaza sempre, mas se vim esses vento de cima, aí ela enche, aí ela represa” (Sr. Dino, 67 anos, pescador artesanal); "Quando chove lá pra cima e dá vento sul ou su-este, claro, aí cresce. Entra aí. Dá represo, né. Aí é o represo que chama, represo d'água" (Gordo, 39 anos, pescador artesanal); "Só quando tá ameaçando tempo ruim que aí dá represo, né, aí ela... aí ela enche. Quando se 
prepara rebojo, um tempo, né (...). Quando tá ameaçando tempo, que o tempo tá ruim, aí ela vira na enchente. Mas é cum rebojo e sul, né” (Delso, 43 anos, pescador artesanal).

O represo, por sua vez, presente em diversas respostas, é "quando o oceano vem pra costa", quando "o oceano alteia", quando "ele cresce"141. Este "represo" é gerado pelos "ventos de cima" e "de água salgada" em contraposição a um menos citado e conhecido gerado pelos "ventos de baixo" e "de água doce":

Tem o represo de água salgada e tem o de água doce também: quando tá água doce, dá vento nordeste, tem muita água pra cima da chuva, aí ela vem. Se dé vento de cima, dá represo de água salgada e se junta uma cum a outra e alteia a água. $\mathrm{O}$ represo de água salgada tem que tá bem baixa pra salgá, aí ela entra pra dentro. (Delso, 40 anos, pescador artesanal).

E a época do rebojo é pelo seguinte, que aí é muito rebojo demais entendesse. Aí a tendência da boca da barra é só metê pra dentro, cresce na praia, né. É imitante quando tem chuva lá pra cima: ela cresce aqui porquê? Porque tem muita água de lá e ela tem que vim embora pra cá. E quando é rebojo que ela cresce muito aqui na praia, a barra tem que metê pra dentro (...). É uma época que ela anda mais cheia. (Sindo, 40 anos, pescador artesanal).

Altas descargas fluviais associadas aos "ventos de baixo" ('quando tá água doce, dá vento nordeste, tem muita água pra cima da chuva') geraria o transporte de grande volume de água doce para a face sul do estuário ('Porque tem muita água de lá e ela tem que vim embora pra cá') dificultando a saída de água pela barra, o que faz a água "altiar", ou seja, resulta no "represo de água doce".

A ação local do vento "rebojo", no entanto, não é o único que produz dois efeitos sucessivos e opostos no regime de vazante e de enchente no Saco do Arraial. O vento noroeste também produz efeitos inversos nas correntes do "nosso mar":

É, o noroeste vaza... quando tem pouca água, agora quando tem água aí pra cima ela enche, ela vem mesmo! Agora quando tem pouca água não, aí seca isso aí. (Sr. Dino, 67 anos, pescador artesanal).

O Noroeste tira água daqui pra fora. Quando ela tá cheiona dá um vento noroeste puxador ela baixa bastante. (...). A não sê que teje muita água pra lá, arrecoa, né, aí na calma faz enchê... até cum noroeste mesmo. Calminho, sendo calminho. (Sr. Oswaldo, 72 anos, ex-pescador-lavrador).

O noroeste, aqui, sendo forte ela vaza. Esgota num minuto! Pode tá numa água cheia aqui que ela, deu noroeste, se vai pra fora. (...). Mas aí é cum vento forte, né, não que ele venha assim calmeiro. Geralmente noroeste ele dá-le mesmo! (Moisés, 45 anos, pescador artesanal).

\footnotetext{
${ }^{141} \mathrm{Na}$ literatura e em textos técnicos científicos do RS (BARCELLOS, 1966; VIEIRA e SCALABRIN, 1991; PASQUOTTO, 2005), o vento "rebojo" é decodificado como "represo" equivocadamente.
} 
O efeito causado pelo vento noroeste depende de dois fatores: intensidade do vento ('calmeiro' ou 'puxador') e a existência ou não de "água lá pra cima” ('...quando tem pouca água, agora quando tem água aí pra cima...'), nesta ordem de importância. Se o vento for "puxador"142 o regime gerado é vazante, tendo ou não "água lá pra cima" ('O noroeste, aqui, sendo forte ela vaza. [...]. Pode tá numa água cheia aqui que [...] se vai pra fora') Porém, se o noroeste for fraco (ou 'calminho') o regime gerado é de vazante se "não tivé água lá pra cima” ('o noroeste vaza... quando tem pouca água') ou de enchente "se tivé" ('quando tem água aí pra cima ela enche').

O regime de vazante provoca o empilhamento de água na metade leste do corpo principal estuarino:

Ela recoa e alteia lá, Capivara, naquelas parte do Norte alteia, e pra nóis aqui baixa. (...). O Noroeste alteia na parte de lá, né, na Torotama já também não, já despraia também. Despraia no Mosquito e despraia na Torotama. Ela corre toda pra fora, né. Ela sai mesmo, num fica nenhum mesmo. Ali no Mosquito ela fica sequinha, sequinha. (Moisés, 45 anos, pescador artesanal).

Além do empilhamento na metade leste ('Ela recoa e alteia lá, Capivara, naquelas parte do Norte ${ }^{143}$ ), provoca o "despraiamento" na borda leste do território coreano ('Despraia no Mosquito'). Com a "calma" do vento noroeste, a água empilhada retorna:

\begin{abstract}
Aí na calma ela volta de novo. É a natureza, né. Ela arrecoa pra lá, quando calma ela vem de novo. Quando virá pro rebojo também acontece de enchê na calma. (Sr. Oswaldo, 72 anos, ex-pescador-lavrador).

Calmô ela enche. Ah, enche! Aí vira na enchente e corre dois-trêis dias seguido na enchente sempre... até o rebojo metê as bota. (...). Dá-le mesmo pra fora! Que ele vem soprando mesmo, né, cara. (...).E depois no cabo de meia-hora, uma hora, ela vem vindo, vem vindo e volta ao normal de novo. (Moisés, 43 anos, pescador artesanal).
\end{abstract}

Neste sentido, a calma do noroeste produz um regime de enchente devido ao retorno da água empilhada na parte leste do estuário da Lagoa dos Patos e ao giro antihorário do vento: do noroeste ao rebojo ('Quando virá pro rebojo também acontece de enchê na calma'). Subsequente à calma do vento noroeste é a ação não-local do vento "rebojo" que passa a dominar o regime de correntes estuarina até que se inicie a sua ação local ('até o rebojo metê as bota'). Portanto, o vento noroeste é agrupado nos

\footnotetext{
142 "vento puxador" = vento forte e permanente.

${ }^{143}$ A comunidade de pesca "do Norte" e da "Capivara" são os pescadores da cidade de São José do Norte. Para localização das comunidades ver Figura 1.
} 
"ventos de cima" quando se ignora a geração de um regime de vazante com "água lá pra cima”.

Vale pontuar, no entanto, a ação do vento "éste" (Leste). Para os pescadores sua ação é insignificante para a hidrodinâmica das águas da Coréia, não merecendo, por isso, para alguns, ser considerado "vento de baixo" ('O vento éste estabelece água aí, mantém ela, não é vento de baixo não' Sr. Dino, 67 anos, pescador artesanal) ${ }^{144}$.

Quando as águas do Saco do Arraial "corre de enchente" e "de vazante", no entanto, a "força d'água" é diferente, ou seja, as correntes de enchente e de vazante não têm a mesma intensidade:

Óia, é conforme, quando é água doce, aí ela tem força na enchente. $\mathrm{Na}$ enchente não, na volta. Aí ela tem força. Mas quando ela tá salgada não, a água de vazante tem mais força. Na vazante, quando ela vaza, vaza pra valê mesmo. Aí ela vaza cum mais força. Sempre a vazante teve mais força. A enchente não, a enchente ela tem menas força. (Sr. Dino, 67 anos, pescador artesanal).

Ah, aí depende... Cum água baixa, salgada, a maior força é de vazante. Quando vem água lá de cima, aquelas ponta de água doce cum nordeste, aí vem cum força, aí enche mais ainda. Enche aqui, mas do outro lado tá vazante. Mas nóis trata que enche, ela enche. (Delso, 40 anos, pescador artesanal).

Segundo os pescadores da Coréia, com “água doce lá pra cima” as correntes de enchente têm maior intensidade ('quando é água doce, aí ela tem mais força na enchente') ${ }^{145}$, sobretudo se associada à ação de ventos como o nordeste ('aquelas ponta de água doce cum nordeste, aí ela vem cum força'). Já com água salgada, as correntes de vazante têm maior intensidade ('Cum água baixa, salgada, a maior força é de vazante').

Dentro do padrão circulatório de "águas baixas", com divisão de água, há variações na "feição" da água quando as águas "tá baixa": "Quando a água tá baixa muda a feição, a água corre costiando a croa e quando ela tá alta não ela corre por cima. Muda, é muito diferente" (Gordo, 39 anos, pescador artesanal). Neste sentido, quando

\footnotetext{
${ }^{144}$ Quando se pergunta diretamente pela ação do vento "este" a resposta é sempre de desdém, ainda que haja água "lá pra cima". No entanto, em várias narrativas e na aplicação de questionários é observado o reconhecimento pela produção de um regime de vazante estuarina quando há baixa precipitação pluviométrica. Por isso, mesmo na oposição binária dos "ventos de cima" e dos "ventos de baixo", o "éste" é geralmente colocado neste último.

${ }^{145}$ Vale lembrar que quando a divisão de águas é extinta no interior do Saco do Arraial pela ocorrência de chuvas, para alguns pescadores é abolida a convenção de enchente no "nosso mar" ('Na enchente não, na volta'; 'Aí só vaza, num enche, vaza sempre') devido o regime de vazante estuarina estabelecido barra afora.
} 
"as croa fica de fora", o que só ocorre com água salgada, o padrão circulatório obedece ao desenho dos bancos de areia.

Por outro lado, dentro do padrão de circulação em que "a água corre na volta", há no interior do Saco do Arraial, uma estratificação vertical de salinidade, sem mistura de água doce e salgada:

Aqui dentro também as veiz acontece (...): as veiz por cima vaza e por baixo enche. (...). É, também tem essa aí: por cima é doce e por baixo é salgada. (...). Por baixo é clarinho e por cima é sujo. É só quando tá assim que enche por baixo e vaza por cima. É que uma água num se mistura uma cum a outra, né. (Sindo, 40 anos, pescador artesanal).

Ainda que zona de "baixio", no interior do Saco do Arraial é observada frequentemente uma estratificação vertical de salinidade ('por cima é doce e por baixo é salgada') com correntes de enchente por baixo e de vazante por cima ('É só quando tá assim que enche por baixo e vaza por cima' $)^{146}$.

Há ainda o empilhamento de água no interior do "nosso mar", na costa da Ilha dos Marinheiros e na da Ilha da Torotama ${ }^{147}$ :

Enche, cum vento de cima ela enche mais pra lá, pois ele empurra ela pra lá. (...). Cum vento de cima leva pra lá (Torotama). E acontece de altiá mais aqui também. Aí é cum nordeste e norte, quando tem água, né, quando num tem ela baixa dos dois lado. (Sr. Oswaldo, 70 anos, ex-pescador-agricultor).

Como pode ser visto, também no empilhamento de águas no interior do Saco do Arraial, o vento e a descarga fluvial continuam sendo as principais forçantes. Os "ventos de cima" empilham água na costa da Torotama, enquanto os "ventos de baixo" (N, NE e NO) teria duas ações: "quando tem água lá pra cima" ele empilha água na costa da Ilha dos Marinheiros e "quando num tem", levaria a um regime de vazante do Saco do Arraial sem qualquer empilhamento de água ('quando num tem ela baixa dos dois lado').

“Ali fora", nas bordas do território coreano, também ocorre o empilhamento de água: "Ali fora quando dá nordeste alteia mais pro lado da Torotama e cum rebojo despraia" (Evaldo, 36 anos, pescador artesanal). Para o empilhamento de água "ali fora”, o vento é a principal forçante. $\mathrm{O}$ vento nordeste empilha ('alteia') água na costa

\footnotetext{
${ }^{146}$ A estratificação de salinidade é uma típica característica de estuários do Tipo Cunha Salina.

${ }^{147}$ Apenas 6 dos 21 entrevistados sabiam sobre o empilhamento em uma das ilhas e apenas 4 sabiam sobre o empilhamento no "costão" das duas ilhas.
} 
da Torotama e com o vento "rebojo" a água "recoa" (ou 'despraia'), empilhando água do lado de São José do Norte e da Várzea ${ }^{148}$.

Por fim, no Saco do Arraial, é notado pelos pescadores que em alguns locais, em determinadas situações, a água salgada "guenta um bocado de tempo" com "água doce na volta" e vice-versa, ou seja, não é rara a ocorrência de água residual:

\begin{abstract}
Na Pinguela, na Agulha, no Boto aguenta um bucado de tempo. Basta que tá doce tudo aqui agora, na Pinguela tá salgada. (...). Na Quitéria, no Arraial, ali tá tudo salgado. Agora tem que dá muita chuva pra adoçá que nem aqui. (...). Caso contrário vai guentá um monte de tempo ali. Agora vai entrá inverno adentro, bem dizê, cum água salgada ali. Só se chuvê muito, só se metê muita água lá. (Gordo, 39 anos, pescador artesanal).
\end{abstract}

A presença de água residual, segundo o conhecimento ecológico tradicional, é condicionada pela baixa descarga fluvial ('...tem que dá muita chuva pra adoçá que nem aqui. [...]. Caso contrário vai guentá um monte de tempo ali’) em período de transição entre o padrão de circulação com divisão de águas e com a água "correndo na volta da Ilha” (“Agora vai entrá inverno adentro, [...], cum água salgada ali. Só se chuvê muito, só se metê muita água lá'). Predominantemente, as águas residuais ocorrem em locais considerados de "água mais parada": "Saco do Boto", "Saco da Pinguela", "Saco da Agulha" e "Saco da Quitéria".

Portanto, segundo os pescadores da Coréia, há duas principais forçantes da hidrodinâmica do "nosso mar". A forçante mais influente na geração de correntes de enchente e de vazante seria os ventos e a segunda, as chuvas. A ocorrência ou não de chuvas gera dois padrões de circulação estuarina, embora mesmo com as chuvas o nível médio das águas, as intensidades das correntes de enchente e de vazante e até a determinância de regimes de enchente e de vazante, também sejam moduladas pelos ventos.

\title{
4.2.1. Implicações hidrodinâmicas das águas "de Pelotas" e "de Porto Alegre"
}

Como foi visto em 4.1, os pescadores da Coréia agrupam as massas de água doce em duas categorias de acordo com sua origem. A massa de água oriunda do rio

\footnotetext{
${ }^{148}$ Vale lembrar que anteriormente foi visto que o vento noroeste tem a mesma ação do que o "rebojo" no que se refere ao empilhamento de água "ali fora".
} 
São Gonçalo é a "água de Pelotas" e a massa de água oriunda estuário acima do rio São Gonçalo é a "água de Porto Alegre" "149. Estas duas massas de água têm implicações hidrodinâmicas distintas em território coreano. "Se a água vié de Pelotas", ou seja, sendo a massa de água doce oriunda apenas "de Pelotas", "ali fora", borda leste do território coreano situada no corpo principal do estuário, ocorre uma estratificação lateral de salinidade ${ }^{150}$ :

Essa água de Pelotas ela vem costa afora, ela costeia aqui. Ela costeia: a água do canal tá salgada e aqui ela vem costa fora é doce. Ela entra pra cá sempre, num precisa de vento nenhum: dá o su-este ela recoa, o vento daqui de cima, sul e su-este ela recoa, (...). Se tivé calmaria ela vem igual. (Amarildo, 40 anos, pescador artesanal).

Portanto, a leste do corpo principal estuarino a água é salgada ('a água do canal tá salgada') e a oeste a água é doce ('Aqui ela vem costa afora é doce’). A água doce "costeia", na Torotama, e "entra pra cá", ou seja, adentra o "nosso mar".

Após entrar "aqui dentro", a massa de água "de Pelotas" traz implicações hidrodinâmicas diversas às massas de água "de Porto Alegre". Uma delas é o tempo de residência das águas:

Se tu pegá e dizê pra mim assim ó: 'Sindo, Porto Alegre tá por cima de toda a água’. Mas é uma água, pode perguntá pra qualqué um que pesca, pode tá a maior enchente lá, mas duas semana ela chega aqui tapando tudo, mas duas semana ela vai embora. Agora tu chega aí na Mirim, tem uma aguinha que ali roda mês. (Sindo, 40 anos, pescador artesanal).

Neste sentido, pode-se dizer que o tempo de residência da massa de água de Pelotas é maior ('...aí na Mirim, tem uma aguinha ali que roda mês') que a de Porto Alegre ('duas semana ela chega aqui tapando tudo, mas duas semana ela vai embora'), provavelmente o tempo de residência da primeira seja o dobro da segunda ('mês'/ duas

\footnotetext{
${ }^{149}$ Buscando correspondência entre as categorias científicas e as nativas, na categoria "água de Pelotas" os pescadores agregam a influência do complexo hidrográfico Mirim, que deságua na Lagoa dos Patos através do rio São Gonçalo, enquanto na categoria "água de Porto Alegre", a das bacias hidrográficas que constituem o complexo da Lagoa dos Patos ao norte do rio São Gonçalo: a do Jacuí/Taquari, do Caí, dos Sinos, do Gravataí, do Velhaco, do Camaquã e do Litoral. Curiosamente, segundo HERZ (1977), o Lago Guaíba e seus afluentes (sobretudo os da bacia hidrográfica do Jacuí/Taquari) são os que mais contribuem com descargas fluviais ao sistema lagunar, seguido do rio Camaquã.

${ }^{150}$ A estratificação lateral de salinidade configura um estuário do Tipo C ou lateralmente estratificado, embora não seja gerada pela força de Coriolis como geralmente ocorre (Miranda et al, 2002).
} 
semana'), embora nem todos os pescadores saibam precisar uma ordem de grandeza temporal $^{151}$.

A atuação dos ventos nordeste e noroeste têm efeitos diferentes sobre as massas de água "de Pelotas" e "de Porto Alegre" como forçante de "enchente" no Saco do Arraial:

O noroeste tira água de Pelotas e Porto Alegre é leste e nordeste. Porto Alegre tá aqui ó (na direção nordeste), é a feição de trazê ela. Antão ele empurra ela, ela cresce aqui na saída dela. Pelotas é aqui ó, noroeste. Aí nordeste tranca a de Pelotas na barra de Pelotas ali. Fica de cara, tranca, né. (Sindo, 40 anos, pescador artesanal).

Somente a massa d'água de "Porto Alegre" causa um regime de enchente no "nosso mar" com vento nordeste ('...Porto Alegre é leste e nordeste. Porto Alegre tá aqui ó [na direção nordeste], é a feição de trazê ela'), pois se é "de Pelotas", devido à disposição geográfica da boca do rio São Gonçalo, o nordeste impede que ela desemboque para a Lagoa dos Patos ("Aí nordeste tranca a de Pelotas [...]. Fica de cara, tranca, né’) e, assim, estabeleça um regime de "enchente" no "nosso mar". Já a ação do vento noroeste favorece a saída de água do rio São Gonçalo ('O noroeste tira água de Pelotas').

Qualquer uma das massas de água, "de Pelotas" ou de "Porto Alegre", gera um regime de enchente no "nosso mar", no entanto, quando as condições são de "calmaria": "Ela vem cum calma, ela vem até cum calmaria. É quando ela vem mais" (Amarildo, 40 anos, pescador artesanal).

Neste momento, algumas considerações são necessárias sobre as estratificações de salinidade e as misturas de massas de água. Como foi visto em 4.2, em períodos em que o estuário tende a passar de um padrão de circulação com divisão de águas para aquele em que a água "corre na volta" ou vice-versa, há a possibilidade de uma estratificação vertical transitória das águas da Coréia. Quando há descarga fluvial no rio São Gonçalo ('água de Pelotas') ocorre uma estratificação lateral de salinidade transitória no corpo principal do estuário ('ali fora') e a predominância de água doce no Saco do Arraial ('aqui dentro'). Nos demais momentos, a água se encontra "misturada",

\footnotetext{
${ }^{151}$ A percepção temporal dos pescadores não é o tempo do relógio. Isto implica que a ordem de grandeza do tempo de residência das águas que foi informado pode não corresponder a esta escala de tempo quando medido.
} 
“endoçando" ou "se cortando", “doce" ou "cortada"152, ou seja, não há pronunciadas estratificações de salinidade ${ }^{153}$.

\title{
4.2.2. "A Lua movimenta cum todo o mar"
}

\author{
"Tem pessoa que acha que a Lua é pra mexê nela, isso e aquilo. Num é não: \\ Deus botô a Lua foi por causa da Terra! (...). Ela manobra no mar como \\ manobra na terra: o Sol pra alumiá e a Lua pra manobrá cum o globo terrestre. \\ (...). Uma coisa eu num posso explicá. Sabe qual que é? E'aquilo que tem \\ dentro dela, o que é. A gente num olha pra ela num tem um troço dentro, umas \\ árvores, um...? Aquilo ali eu num posso explicá o que pode sê aquilo ali. \\ Aquilo é um mistério que tá dentro, né. Tem uma imagem, a gente olha, mas \\ num sabe o que que é, né. Aquela imagem parece uma serra, né. Num sei o que \\ é aquilo ali. Pra mim aquilo ali é o conteúdo que manobra cum a Terra. Pra \\ mim é aquilo ali! Eles tiveram vontade de descobri, mas num conseguiram. \\ Eles queriam sabê o que era aquilo ali, mas num souberam. E'mistério que \\ Deus botô ali dentro. Mas olha: a Lua tem um grande, tem um grande objetivo \\ cum a Terra!". (Sr. Dino, 67 anos, pescador artesanal).
}

A Lua detém influências no comportamento hidrodinâmico, atmosférico e biológico das espécies, embora conhecidas por poucos ${ }^{154}$. Neste item, no entanto, será discutida apenas a sua influência direta na hidrodinâmica do Saco do Arraial.

A primeira influência a ser discutida é a de acordo com as marés de sizígia e quadratura:

Ai, Lua? Lua é brabo! A Lua cheia procura mais enchê a água. (...). De acordo que vai enfraquecendo a Lua, já quase pra minguá, ela já corre menos... já muda, vai mudando. Mas no forte dela, ela enche, ela procura enchê. (...). A minguante é uma Lua de água normal quase, nem cheia nem baixa. Ela fica naquilo: ela enche, mas daqui a pouco vira de vazante. Ela num tem muita... ela faz duas-trêis vezes na noite ou dia ela faz isso: enche e vaza ou vaza e enche. É, num tem muita firmeza não. E a Lua nova já puxa mais pra baixo, né. Tem veiz que ela baixa bem. A crescente vem a sê quase o mesmo que a minguante. (Moisés, 45 anos, pescador artesanal).

A Lua manda muito. Agora, depende, mas, as veiz, a Lua, pra ela corrê, quase sempre igual é mais pra crescente pra corrê de enchente. E a Lua cheia também pra corrê de enchente. (...). Quando ela vem, que ela pega força de enchente, ela vem correndo por tudo isso aí. As outra já são mais pra vazante. (Sr. Meca, 68 anos, pescador-lavrador).

\footnotetext{
152،“'́gua cortada" = água salgada; "Se cortando" = tornando-se salgada.

${ }^{153}$ A estratificação vertical e lateral de salinidade e a mistura de massas de água doce e salgada são características de um estuário do Tipo Cunha Salina, Lateralmente Estratificado para as duas primeiras situações, respectivamente, e do Tipo Moderadamente Misturado ou Verticalmente Bem Misturado, para a terceira situação, segundo Miranda et al (2002).

${ }^{154}$ Dos 21 pescadores artesanais e pescadores-lavradores entrevistados, apenas 9 souberam dizer alguma influência da Lua na atividade pesqueira.
} 
Segundo a lógica de oposição binária, para os pescadores coreanos a Lua cheia gera um regime de enchente ('A Lua cheia procura mais enchê a água'; 'E a Lua cheia também pra corrê de enchente'), enquanto a Lua nova gera um regime de vazante no Saco do Arraial ('E a Lua nova já puxa mais pra baixo, né. Tem veiz que ela baixa bem'; 'As outra já são mais pra vazante'). Já para as Luas crescente e minguante há algumas incoerências. Para alguns a primeira é "mais pra enchê" e a segunda "mais pra vazá", respectivamente, enquanto outros dizem que as duas "enche mais daqui a pouco vira de vazante" e, por isso, "num tem muita firmeza". Estas contradições, no entanto, são apenas incoerências aparentes, como pode ser ilustrado pela entrevista com o mais experiente dos pescadores artesanais da Coréia:

Cum a Lua cheia enche e cum a Lua nova pega-pra-vazá. A crescente não: é uma Lua fraca, num mexe cum nada. A crescente tá pegando força pra cheia. É que nem a minguante: é uma lua fraca, mas tá se perparando pra nova, pra vazá. (Sr. Dino, 67 anos, pescador artesanal).

Neste sentido, as Luas minguante e crescente não podem ser categorizadas nas categorias de oposição "vaza" ou "enche", mas "perparação pra vazá" ou "pra enchê", respectivamente. Portanto, as Luas crescente e minguante constituem estados transicionais opostos: a tendência à enchente e à vazante que são consolidadas pelas Luas cheia e nova, respectivamente.

Nas ilhas Torres Strait da Austrália, a influência das Luas cheia X nova e minguante $\mathrm{X}$ crescente também é categorizada segundo a lógica de oposição binária. As marés de sizígia constituem as correntes mais intensas e mais fracas, enquanto as marés de quadratura mantêm menor grau de diferença entre as correntes mais intensas e mais fracas (NIETSCHMANN, 1989). No Rio Grande do Sul, Adomilli (2002) pontua que as Luas estão associadas às marés, apesar de não dizer como isto ocorre.

Por outro lado, a influência da Lua na geração de correntes estuarinas tem seus limites: "Porque também a Lua manda muito também na corrente d'água, né, a água salgada normal mesmo a Lua mexe a água. Cum água doce num mexe nada não" (Delso, 40 anos, pescador artesanal). A influência das marés de sizígia e quadratura, portanto, ocorre desde que não haja grandes descargas fluviais.

Em outros estuários do Brasil em que a maré astronômica é mais pronunciada, as chuvas não diminuem a influência da maré, como Cordell (1974), Marques (1991) e Souto (2004) descreveram para estuários da Bahia segundo o conhecimento tradicional. 
Durante a vigência da maré lunar, é a "entrada" ou a "saída" de uma das Luas da terra que vai estabelecer os seus respectivos regimes de enchente e de vazante:

\begin{abstract}
As veiz tu tá trabalhando aí numa baita vazante, a Lua nasce e a água pára... e bota pra enchente. (...). As veiz a água tá enchendo muito, as veiz tu quéis uma água de vazante, tu espera nascê a Lua: 'Ela vai virá...'. E vira memo! E outras veiz ela tá parada e quando nasce a Lua, ela bota pra corrê ou prum lado ou pro outro, ou de enchente ou de vazante ela bota pra corrê... que a Lua mexe cum ela. Aí é quando a Lua nasce ou quando entra... é, é quando ela entra ou quando nasce, seja qual fô. (Sr. Dino, pescador artesanal, 61 anos).
\end{abstract}

Neste sentido, de acordo com o "movimento cum o mar" de "virar" ou "desvirar", pode-se dizer que há duas categorias de Luas: a "de entrada" e a "de saída" ou "quando nasce". A entrada e a saída da Lua, seja de sizígia ou de quadratura, gera a inversão das correntes de enchente para vazante ou vice-versa ('...ela bota pra corrê ou prum lado ou pro outro, ou de enchente ou e vazante [...]. Aí é quando a Lua nasce ou quando entra [...], seja qual fô').

Outra questão que deve ser pontuada é a polissemia acerca o termo "força" da Lua:

É quando ela entra ou quando ela tá saindo também. As veiz ela vaza o dia todo, quando ela começa a nascê ela vira na enchente. É que nem tá agora, ela tá cheia, né, tem enchido pra caramba, né. Aí ela vai até umas três hora, quatro hora, aí desvira na vazante. Enfraquece, né, ela vai entrando. Quando ela vem nascendo ela fica mais forte, né, e quando ela vai entrando já vai enfraquecendo. Então ela já cumeça-mudando. (Moisés, pescador artesanal, 43 anos).

A Lua "de saída" seria a "forte", já que determina o vetor das correntes estuarinas inerentes àquela maré lunar, enquanto a Lua "de entrada" seria a "fraca", pois ela perderia a capacidade de influenciar o vetor das correntes permitindo um contrário ao que lhe é atribuído ('É que nem agora, ela tá cheia, né, tem enchido pra caramba. Aí ela vai até umas três hora, quatro hora, aí desvira na vazante. Enfraquece, né, ela vai entrando"). O sentido do vetor tomado pelas correntes da lua "de entrada" e "de saída", enchente ou vazante, é definido, portanto, pela maré lunar.

Por outro lado, a "força" também está ligada ao atraso diário da "Lua de saída":

Tens que vê o seguinte: se ela vai sê cheia hoje, no escurecerzinho, logo que entrá o sol, ela aparece. Mas ela vai atrasando cada dia quarenta minuto, né, (...). Se sete hora ela apareceu cheia, no outro dia vai aparecê sete e quarenta 
e daqui a pouco tá oito e pouco e vai indo e vai indo. Aí, daqui a pouco, a cabo de uma semana, tá nascendo umas deiz-onze hora da noite. (...), isso aí também faz o movimento da água também, né, aí vai mudando, né. (...), é quando enche mais, é o forte da Lua cheia, né, o primeiro dia dela, logo que entra o Sol ela sai. (Sindo, 40 anos, pescador artesanal).

Assim, à medida que uma Lua passa de um quarto a outro, de sizígia à quadratura e vice-versa, e seu tempo de permanência no céu diminui, devido ao atraso da "de saída" ("ela vai atrasando cada dia quarenta minuto, né [...]. Aí, daqui a pouco, a cabo de uma semana, tá nascendo umas deiz-onze hora a noite'), ela perde sua "força" ('é o forte da Lua cheia, né, o primeiro dia dela, logo que entra o Sol ela sai'). Portanto, retomando um fragmento da primeira fala de Moisés (43 anos, pescador artesanal):

\begin{abstract}
A Lua cheia procura mais enchê a água. Depende como ela tá no caso, né: se ela tá no forte ou no fraco. Se ela tá no forte da Lua ${ }^{155}$, ela procura enchê. De acordo que vai enfraquecendo a Lua, já quase pra minguá, ela já corre menos... já muda, vai mudando. Mas no forte dela, ela enche, ela procura enchê. É mais à noite, né.
\end{abstract}

A "força" de uma Lua, ou seja, a capacidade de gerar a corrente de enchente ou de vazante, relacionada ao seu atraso na "saída", assim como a sua entrada e saída, articula-se à maré lunar, pois a corrente é correspondente à determinada maré lunar ('De acordo que vai enfraquecendo a Lua [cheia], já quase pra minguá, ela já corre menos [...]. Mas no forte dela, ela enche'). A influência da saída da Lua e do seu atraso diário, ambos articulados à determinada maré lunar, também são observados pelos ilhéus de Torres Strait (NIETSCHMANN, 1989).

Por fim, ressalta-se que não é por acaso que a maior parte das falas dos pescadores remetem a ação "da Lua" em detrimento das outras, pois "A Lua cheia é a Lua mais forte", ou seja, a corrente produzida pela Lua cheia é a de maior intensidade, sobretudo no seu primeiro dia, e, de longe, a mais perceptível. Em estuários com sinal de maré mais pronunciado, os pescadores não destacaram a influência maior de determinada Lua. Ao contrário, como pode ser visto em Cordell (1974), Marques (1991) e Souto (2004), todas exercem grande influência.

\title{
4.2.3. "Quando as estrelas troca de lugar no céu o mar sente"
}

\footnotetext{
${ }^{155}$ Quando os pescadores da Coréia dizem "a Lua", eles se referem quase sempre a Lua cheia.
} 
Um tanto inusitado foi a crença de que as estrelas cadentes movimentam com a água "aqui dentro": "Quando as estrelas troca de lugá no céu, elas mexe cum o mar". Esta frase pode ser atribuída a autoria de qualquer um dos meus entrevistados, pois todos repetiram a mesma coisa.

O movimento que eles descrevem com os gestos ('Mexe assim ó... abre um buraco no mar') seria um afundamento da região mais central do "nosso mar" em decorrência de um empilhamento nas bordas.

Aguilera (1994) transcreve o mesmo constructo "a estrela cadente troca de lugar no céu" que ganha diferentes significados de acordo com o contexto cultural e regional do estado do Paraná. Berta-Ribeiro (1995) observou entre os índios Desâna, da Amazônia, a percepção da influência de constelações na transparência da água.

De acordo com os dados de observação de campo, pode-se dizer que, no caso da Coréia, a estrela cadente aumenta a visualização no entorno do pescador, a pesca é predominantemente à noite, facilitando a visualização dos peixes no "mar", que segundo eles, "urram"156 com a passagem da estrela cadente. Este fato merece investigações mais detalhadas, mas preliminarmente aponta-se que "mar" e "peixe" para eles são entidades indissociáveis. Por isso, se "mexe" com o "peixe", "mexe" com o "mar".

\subsubsection{A hidrodinâmica das grandes enchentes}

As enchentes que ocorrem frequentemente no entorno da Lagoa dos Patos também são categorizadas de acordo com a lógica da oposição binária. Há duas categorias de enchente:

Tem aquelas enchentes que vêm quase em temporal, ela vem de topo, de repente, e outras como a enchente de quarenta e um (1941) que veio de calmaria, uma aragem (de NE) assim. (Sr. Walter, 84 anos, ex-pescadoragricultor).

Que ela vem cum calmaria é fartura de água. Essa aí é a verdadeira enchente! (...). Agora, essa que veio pra nóis, (...), foi a maior enchente que eu cunheço do meu tempo, ela veio cum temporal de vento nordeste. (...). Ela cresceu das

\footnotetext{
${ }^{156}$ Fala-se que o peixe "urra" quando ele pula em grande quantidade para fora d'água: "De noite se tu ligá o cilibrinho em cima da manta do peixe, ela urra, ela pula, sapateia que nem..." (Moisés, 43 anos, pescador artesanal).
} 
oito da manhã ao meio dia. (...). Quando o vento calmô foi de tarde. À noite a gente tava passando o pano no assoalho da casa aí. Ela veio e foi embora. Agora cum calmaria ela veio na Torotama a vinte e dois anos atrás e levô um mês que tu num tinhas terra pra botá os pé. Era só água! (...). É quando ela (a água) é muito em Porto Alegre, em Pelota, ela faz isso cum nóis aqui. (Sr. Meca, 68 anos, pescador-agricultor).

As "enchentes de calmaria" ocorrem devido à grande quantidade de água "lá pra cima" ('Que ela vem cum calmaria é fartura de água. [...]. É quando ela é muito em Porto Alegre, em Pelota...') e dura por volta de um mês ('Cum calmaria [...] levô um mês pra baixá'), enquanto as "de tempestade" ocorrem devido às descargas fluviais associadas a tempestades de vento ('a maior enchente que eu cunheço do meu tempo, ela veio cum temporal de vento nordeste') durando menos tempo ('Ela cresceu das oito da manhã ao meio dia. [...]. Quando o vento calmo foi de tarde. À noite a gente tava passando o pano no assoalho da casa aí').

É interessante notar que tanto a enchente "de calmaria" quanto a "de tempestade" tem como princípio de ocorrência o "represo de água doce" e a velocidade de vazão depende de forçantes que aceleram o regime de vazante estuarina, como o vento nordeste. Portanto, ambas estão associadas às principais forçantes do estuário da Lagoa dos Patos: os ventos ('enchente de tempestade') e/ou a descarga fluvial ('enchente de calmaria' e 'de tempestade').

Fraxe (2000) registra que comunidades de pesca da Amazônia que vivem cheias regulares e anuais, devido altas descargas fluviais e sinal de maré na foz do Amazonas, incorporam-na na sua estrutura cognitiva e organizam o ritmo das atividades de agricultura, caça, pesca e estrativismo em função das cheias.

\subsubsection{Alterações hidrodinâmicas: "Então hoje a água passa mais tempo doce do que salgada".}

Ainda que gozem ou não de alguma simpatia dos locais, algumas obras de engenharia têm impactos hidrodinâmicos percebidos pelos coreanos. Dentre várias, há três obras principais de engenharia com diferentes proporções econômicas, de impacto e, consequentemente, de revolta. Uma delas é a ponte que liga a Ilha dos Marinheiros ao continente, chamada pelos ilhéus de "aterro" (ver Figura 2), que trouxe algumas consequências nas correntes de enchentes e de vazantes no interior do Saco do Arraial: 
Se tu olhá lá, ali é só um buraquinho debaixo da ponte pra água passá. Era mais rápido fazê a volta na ilha a água: ou ela vazava mais rápido ou enchia mais rápido. (...). Ah, segura água: quando ela entra aqui ó correndo de enchente e metê água doce, que ela chegá e repexa ali (no 'aterro'), ela num baixa tão rápido aqui também, não. Ela tá em pouca vazão lá, entendesse. (...). Se num existisse a ponte num tinha mais corrente de água ali? Logicamente que tinha, o mar era livre. (Sindo, 40 anos, pescador artesanal).

A primeira resulta do menor espaço de passagem da água ('ali é só um buraquinho debaixo da ponte pra água passá'), pois se torna mais difícil a enchente e a vazante através dela ('ou ela vazava mais rápido ou ela enchia mais rápido’), segundo os pescadores.

O "aterro" também trouxe variações nos padrões de circulação no interior do Saco do Arraial:

Isso aí supõe que seja tapado também lá, né, mudô o lugá da água lá: porque já taparam, já corre menos no aterro. Eu não digo que seje pra empatá a água, que empata água, eu digo pra se encontrá: qué dizê que aqui ('nosso mar') ela corre cum mais força e lá (na 'outra costa') cum menos força pra se encontrá mais pra cá (na croa Grande) agora. Ela corre menos que aqui. (Sr. Dino, 67 anos, pescador artesanal).

Pra mim é aquilo lá: prende muito, prendeu muito. (...). Fica presa um tempo por ali, também ela salga aquele canto da Quitéria, aquele canto do Arraial, mas o nosso mar aqui não salga porque a água doce tá presa. Por causa que ela num dá saída aqui (no 'aterro'). (Moisés, 45 anos, pescador artesanal).

Dentro de cada padrão de circulação, quando as águas se "péxam" ou quando "ela corre na volta", há suas variações: na primeira parece ter havido mudanças no local de encontro de águas devido a uma maior dificuldade no fluxo das correntes de enchente "por lá" ('eu digo pra se encontrá: qué dizê que aqui [nosso mar] ela corre cum mais força e lá [na outra costa] cum menos força pra se encontrá mais pra cá [na croa Grande] agora'), enquanto na segunda há um maior tempo de residência da água doce devido a uma maior dificuldade de para as correntes de vazante ('Fica presa um tempo por ali, também ela salga aquele canto da Quitéria, aquele canto do Arraial, mas o nosso mar aqui não salga porque a água doce tá presa').

Nos períodos entre os padrões de circulação com divisão de água salgada e “cum água doce na volta” também houveram mudanças:

Tempo de entrá água salgada no caso, né. (...). Aqui ela fica presa nesse nosso mar da Agulha, da croa dos Cavalo, Pinguela (...). Ela tá doce aqui, presa aqui dentro, entendesse. Então ela entra aqui, vem até um certo ponto, até a croa Grande, (...) e dali dá a volta de novo. (...). O nosso mar aqui não 
salga porque a água doce tá presa, (...) ela num dá saída aqui (no 'aterro'). Vai empurrando até... tem que levá uns cinco-seis dia, deiz dia, entrando por aqui também nesse nosso mar pra ela misturá aqui e salgá. E antes não, antes ela salgava mesmo: ela entrava por lá e entrava por aqui. (Moisés, 43 anos, pescador artesanal).

No período de transição entre os dois padrões de circulação, a enchente parece duplamente dificultada devido a uma maior dificuldade de vazante da água doce residual ('Tempo de entrá água salgada no caso, né. [...] o nosso mar aqui não salga porque a água doce tá presa') e de enchente da água salgada ('Vai empurrando até... tem que levá uns cinco-seis dia, deiz dia, entrando por aqui também nesse nosso mar pra ela misturá aqui e salgá. E antes não, antes ela salgava mesmo: ela entrava por lá e entrava por aqui').

Uma outra obra que trouxe impactos foi a última ampliação e afunilamento dos molhes da Barra (Figura 4). Segundo os pescadores, a ampliação dos molhes da Barra com seu afunilamento gerou problemas para "esgotá" as descargas fluviais:

Aquilo ali eu acho que atrapalha um pouco, apertaram muito aquilo ali, né, mesmo ficando mais fundo, porque a água corre mais é por cima, né. Por baixo ela corre pouco, (...). Eu acho que eles eram pra alargá. É, porque quando chove custa mais a saí ali, né. (...). Então ela passa mais tempo doce do que salgada. A água doce leva dias e dias correndo aí porque é apertado. Se fosse largo ela ia embora, né. É por isso aí que a água tá doce direto... (Sr. Dino, 67 anos, pescador artesanal).

As obras de ampliação com o afunilamento dos molhes da Barra estabelecem um marco trazendo maior dificuldade no regime de vazante, sobretudo o de água doce ( ‘...apertaram muito aquilo ali [...]. É porque quando chove custa mais a saí ali, né), e a "entrada de água salgada" do oceano: "então ela passa mais tempo doce do que salgada". Neste sentido, há o favorecimento do "represo de água doce" e um maior tempo de residência das águas doces, não só no interior do Saco do Arraial, mas em todo o estuário da Lagoa dos Patos ('A água doce leva dias e dias correndo aí porque é apertado. Se fosse largo ia embora, né. É por isso que a água tá doce direto...’).

A construção de uma "barrage" no rio São Gonçalo durante a década de 1960/70 ${ }^{157}$ para evitar a entrada de água salgada e, assim, favorecer as plantações de arroz em grandes latifúndios ('os arrozeiro'), é responsabilizada pela ocorrência de grandes enchentes:

${ }^{157}$ Datação oriunda de informações das entrevistas com pescadores artesanais. 
Acho eu que era por causa da chuva, chuveu mais lá pra cima, né, caiu umas chuva pesada prali, em Pelotas. É, eu acho que aí enche as barrage e eles se obrigam a solta, né. Quando chove muito lá em Pelotas é quando eles soltam mais. Aí vem água por cima de tudo aqui. (Evaldo, 36 anos, pescador artesanal).

Segundo os pescadores coreanos, quando "chove muito lá em Pelotas", os arrozeiros "soltam as barrage" trazendo grande quantidade de água doce num curto período de tempo, o que se sucede em enchentes ${ }^{158}$.

Por fim, há mais um impacto que contribui para as águas do estuário "passá mais tempo doce do que salgada", mas é apontada apenas pelo pescador artesanal mais velho e mais respeitado da Coréia, a "sangração pro mar":

Tem anos que passa inverno todinho cum água doce de apodrecê os capim todinho aí das praia de água doce. Pior que é! De primeiro não, de primeiro a água secava nos banhado, ela num tinha sangração pro mar, né. (...). Esses arroio começaram quando começaram a fazer as estrada, né, começaram

\footnotetext{
${ }^{158} \mathrm{O}$ estudo de caso da Coréia aponta que os conflitos dos pescadores do RS com as barragens, pelo menos os pescadores afetados pelas massas de água do rio São Gonçalo, dá um estudo a parte. Nos relatos, os mesmos pescadores que culpam os arrozeiros pelas enchentes, se contradizem e remetem a outras causas dos impactos atribuídos aos arrozeiros. Por ex.: "Essas barrage num é muito antiga não, de primeiro num tinha essas barrage, dava essas enchente assim, mas treminava mais rápido. Agora não, agora dá essas enchente demora" (Sr. Dino, 67 anos, pescador artesanal). As enchentes, como o Sr. Dino, já existiam antes das construções das "barrage" só que nos tempos recentes, frequentemente, têm demorado mais. Este maior tempo de residência da água oriunda "de Pelotas" pode ter outras causas definidas pelos pescadores: a ampliação com afunilamento dos molhes da Barra, o "aterro" e a "boca" do rio São Gonçalo estreita, como foi discutido anteriormente. Além disso, "cum água de Porto Alegre também acontece" estas enchentes. Não só às enchentes é atribuído culpa aos arrozeiros, mas a presença de agrotóxicos na água que matariam os "peixes". Este é um dos motivos que a água de Pelotas é qualificada como "água podre". Relatos do Sr. Dino, no entanto, dá um outro motivo que explica porque a “água de Pelotas sempre foi miserável”, não tem "peixe”, em relação a "água de Porto Alegre": "É porque aqui ela (a água de Pelotas) vem do São Gonçalo e a de Porto Alegre vem do Guaíba, ela entra na lagoa e na lagoa sempre tem mais peixe, então vem mais peixe pra nóis. Na lagoa sempre tem bastante peixe, em Pelotas não, em Pelotas num tem peixe, é uma água de terra, né. E a água de Porto Alegre não, ela traz curvina, traz cascote, traz tudo... traz peixe... que a lagoa é grande". Por outro lado, há uma obsessiva atribuição de culpa aos arrozeiros pelas desgraças na pescaria e quase nada é dito sobre estas outras causas apontadas pelo Sr. Dino: "Eles acabaram cum a pesca! Num tem mais água salgada, num tem mais bagre. Num tem mais água salgada, num tem mais a curvina por causa dessas merda, bosta de barrage! (...). Mas a maior força mesmo era de água salgada. Mas cum essas barrage que fizero aí acabaram cum tudo, acabaram cum o mar: aumentô o nível da água" (Guega, 54 anos, pescador artesanal). Não se aponta um equívoco dos pescadores artesanais em relação à rizicultura, como poderiam concluir convenientemente os mais apressados, pois o mecanismo de funcionamento das barragens artificiais no Canal de São Gonçalo, descritas pelos pescadores, é registrado pela literatura científica: "o fluxo de água através do Canal de São Gonçalo é controlado por barragens artificiais, para impedir a penetração de água salgada do estuário para a Lagoa Mirim e somente durante períodos de grande acumulação de água na Lagoa Mirim, estas barragens são abertas" (GARCIA, 1998: 19). O que se sugere é uma ruptura com uma possível análise científica inocente e um caminho para a compreensão das várias dimensões que os conflitos entre pescadores X "arrozeiros" criando uma hipótese: a origem dos conflitos com os arrozeiros é a destruição da pesca na Lagoa Mirim. A preocupação obcessiva de culpar os "arrozeiros" seria uma forma de manter vivo e transmissível para outras gerações o ódio pela destruição de territórios de pesca, como a Lagoa Mirim. Portanto, este seria um vasto assunto para futuras pesquisas sobre conflitos territoriais.
} 
sangrando pro mar pra esgotar as estrada, os banhado (...). Começa chover um pouco, já o mar enche e vem aquela água barrosa. (Sr. Dino, 67 anos, pescador artesanal).

Segundo o Sr. Dino, a construção de pequenos arroios para "esgotá" as estradas e o "campo" (área de plantações e/ou criação de gado) também contribui para aumentar a quantidade de água doce no "nosso mar" e, assim, mantê-lo influenciado pelas descargas fluviais mais tempo.

Portanto, as obras de engenharia têm impactos de diferentes escalas de acordo com a magnitude da obra. A ponte de ligação da Ilha dos Marinheiros ao continente tem impacto em micro-escala, já que dificulta a entrada de água salgada e aumentando o tempo de residência das águas doces residuais no Saco do Arraial ('aqui dentro'). As "barrage dos arrozeiro", localizada no rio São Gonçalo, atua numa escala maior provocando a estratificação lateral de salinidade "ali fora" quando libera água doce e, algumas vezes, grandes enchentes "aqui dentro". A última ampliação dos molhes da barra dificultou a saída de água doce do "nosso mar" e, provavelmente, atinge todo o estuário. Por tudo isso, "hoje a água passa mais tempo doce do que salgada".

Coelho Júnior e Schaeffer-Novely (2000) registram impactos semelhantes, mudanças na drenagem e impedimentos no fluxo de maré, devido a carcinicultura instaladas em mangues. No Rio Grande do Sul, Pasquotto (2005) aponta conflitos entre arrozeiros e pescadores na Lagoa Mirim ${ }^{159}$.

A descrição acima demonstra que não apenas os compartimentos "céu" e "mar" são classificados e pensados, mas que a interação entre eles também são profundamente conhecidas. Por isso, também na interação, “céu" e "mar" são complementares para a compreensão do mundo de pesca coreano. Para Cunha (1987; 2007), a apropriação destes compartimentos ambientais no sentido de uma complementaridade conforma o que ela chama de "saber bio-cósmico", que constrói o espaço marítimo. Para Nietschmann (1989), o conhecimento dos padrões e das interações das "coisas marinhas" torna o espaço marinho social e cultural. Neste sentido, a interação dos ventos, das chuvas, da Lua na geração de correntes estuarinas do Saco do Arraial torna possível a construção do território grupal numa perspectiva etnooceanográfica. Pode-se dizer ainda que, se os processos descritos são frutos do

${ }^{159}$ A Lagoa Mirim é conectada à Lagoa dos Patos pelo rio São Gonçalo (ASMUS, 1998). 
contexto social e cultural do grupo, eles só podem ser aplicados localmente, assim como conclui Forman (1970) sobre os pescadores de Coqueiral. Ou, dito de outro modo, como em Acheson e Wilson (1996), o conhecimento é situado no território.

A hidrodinâmica estuarina, no entanto, não está acabada. Ela será concluída à medida que a interface entre "mar" e "céu" for situada no tempo do "nosso mar" através dos "sinais de memória". É o que será feito em 4.3, a etnocronologia estuarina. A etnocronologia estuarina, por sua vez, é ainda um passo intermediário para a contextualização do território coreano no tempo.

\subsection{Etnocronologia estuarina: "eu manobrava mais é cum a água".}

\subsubsection{O "padrão" etnocronológico: "Aí é certinho safra boa, né”.}

Para inaugurar a construção do tempo do território coreano, subsidiado pelo mecanismo hidrodinâmico do "nosso mar" de 4.2, são criados um conjunto de "categorias" do tempo estuarino que compõem, em 4.4, o contexto estuarino em que se dá a etnocronologia da pesca. Para este fim, usa-se do conhecimento ecológico tradicional do movimento de certos referenciais materiais da natureza, os "sinais de memória". Dentre os vários "sinais de memória" que contróem o tempo tradicional subsidiando as tomadas de decisões, elenca-se aqueles que "estabelecem prazos": “...marcos esses que estabelecem prazos e conexões de anterioridade e posteridade no continuum da consciência pessoal e coletiva" (LEITE, 2007: 116). Os "sinais de memória" que "estabelecem prazos", na proposição de Leite (2007), seriam equivalentes aos marcos que, na perspectiva de Kagame (1975), individualiza o evento, o "tempo disso ou daquilo". Como resultado obtem-se a etnocronologia estuarina, primeira base na construção e apropriação do tempo territorial.

Em consonância, outras pesquisas (CUNHA e ROUGEULLE, 1989; ALLUT, 2000; CARDOSO, 2001; CUNHA, 2007) ressaltam a interpretação da linguagem da natureza, "sinais" ou "indicadores de tempo", através dos movimentos do mar, dos ventos, tonalidade da água, etc. Marques (1991), nas suas considerações "têmporoespaciais", apesar de não ter se utilizado de "sinais de memória" enquanto tal, também observou a intersecção do tempo e do espaço na marcação do tempo na pesca: 
"Aspectos temporais e espaciais aparentemente entrelaçam-se na mente dos pescadores" $(: 119)$.

Para os pescadores coreanos, a particularização de um tempo inicia-se pela oposição binária de dois estados gerados através da ocorrência ou não de um evento, as chuvas:

\begin{abstract}
Depende é a feição de água, né: se tivé bastante água ela vai altiá, se não tivé ela vai ficá naquela, estabelecido aquilo ali, né. Esse ano mesmo, esse ano tá tudo seco essas época aí, ela ficô baixa. Agora já deu essa chuvinha, já deu pra altiá, né. Então, conforme é a chuva é que ela causa. (Sr. Dino, 67 anos, pescador artesanal).
\end{abstract}

Como consequência da ocorrência de chuvas, a água do estuário "alteia" em contraposição às "água baixa" quando "tá tudo seco", ou seja, quando não ocorrem chuvas. Nesta simples afirmação estão contidas todas as bases do tempo percebido da dinâmica estuarina ('água alta' ou 'cheia' e 'água baixa'), assim como todas as variações e incertezas que daí se desdobram ('Depende...', 'Se...', ‘esse ano tá...'). No entanto, mesmo com todas as incertezas, a experiência temporal confere certa previsibilidade às incertezas: "conforme é a chuva é o que ela causa". Como foi visto em 4.2, não é apenas a "altura da água" que a chuva influencia, mas a salinidade da água ('se chuvê a água fica doce' e 'se corrê seco fica salgada'). Neste sentido, tem-se que a ocorrência ou não de chuvas marca uma oposição entre "água doce" e "alta" X "água salgada" e "baixa". Portanto, a chuva é o principal "sinal de memória" que fundamenta esta oposição.

A “água alta" e "doce" e a "água baixa" e "salgada", no entanto, tem uma tendência de acontecer num determinado momento:

Quanto mais vai chegando perto do inverno, sempre vai crescendo mais a água. Todos os ano é isso. Já nota diferença já. Num é aquelas enchente, né, mas já nota diferença do início do verão. Já nota diferença. A tendência agora do inverno é cada vez ela... claro, dependendo do tempo, né, se cumeçá a chuvê não, mas se continuá assim do jeito que vai cada vez mais baixa. (Evaldo, 36 anos, pescador artesanal).

Portanto, a "tendência" da "água cheia" é ocorrer no inverno, criando a categoria "inverno cum chuva", e "da água baixa" no verão, criando a categoria "verão 
de água salgada" ${ }^{\# 160}$. A correlação em comunidades de pesca do Brasil entre períodos de cheias ou de chuvas em oposição aos períodos de secas com o "inverno" e com o "verão", respectivamente, é amplamente documentada como em Marques (1991), Calvente (1993), Souto (2004) e Miller (2005).

Do ponto de vista da principal forçante estuarina, os ventos, há no inverno e no verão tendência de predominância de diferentes ventos:

Tu nota que, agora, vais vê a sequência de vento, agora até janeiro-fevereiro: nordeste. O vento que vai mais soprá no rosto: nordeste! (...). Aí quando chega o inverno... aí é rebojo, rebojo, rebojo e rebojo que dá até nojo, cara. Num visse esse inverno aí: era rebojo atrás de rebojo, num era? (Sindo, 40 anos, pescador artesanal).

No verão, tempo de "água baixa", o vento predominante, até os meses de janeiro e fevereiro, é o nordeste, enquanto no inverno, tempo de "água cheia”, é o "rebojo". Vale lembrar que, como foi visto em 4.2, o vento nordeste é associado ao regime de vazante estuarina, assim como qualquer "vento de baixo", enquanto o "rebojo" é associado ao regime de enchente estuarina, assim como qualquer "vento de cima". Portanto, o "tempo de águas cheias" e o "de águas baixas" são consequências da associação dos regimes de precipitações pluviométricas aos de ventos que geram um regime de correntes de enchente e de vazante, respectivamente.

A partir da tendência do "tempo de águas cheias" e do "tempo de águas baixas" estarem ligados ao inverno e ao verão, respectivamente, tem-se que a influência das Luas na hidrodinâmica estuarina está restrita a uma das estações:

Isso aí vai muito também é conforme tá a força d'água, entendesse. A gente diz a força d'água é a água pra cima: se tem pouca água, se tem muita água. (...). Então ela prende lá, a água doce, e aí qualqué coisinha ela já vem de volta de novo. Porque a outra tá empurrando pra cá, né, a outra tá vindo aos pouquinho. Então não adianta muito a Lua, já modifica um pouco. E quando tá normal, a água tá baixa, da Lagoa, tá salgada, que deixa ela entrá, ela faz os movimento certo. Ela faz certo os movimento... ela vai fazê o que é memo a Lua". (Moisés, 43 anos, pescador artesanal).

Qualquer uma das Luas "faz certo os movimento" quando o estuário "tá salgado", o que restringe sua ação ao "verão de água salgada". A influência da Lua sobrepujada pelas principais forçantes estuarianas lhe condiciona um curto tempo de

\footnotetext{
${ }^{160}$ Portanto, ressalta-se que a discussão da etnocronologia estuarina não será feita com base no início e fim das estações, antes disso dar-se-á bases a partir do "tempo de águas doces" e "altas" e "de água salgada" e "baixa" para o entendimento das categorias de "verão" e "inverno".
} 
influência na hidrodinâmica estuarina. Como consequência, a construção da etnocronologia estuarina se dá em torno da influência das duas principais forçantes estuarinas percebidas, os ventos e as chuvas. Esta característica diferencia as bases da etnocronologia coreana de alguns trabalhos em regiões em que a maré astronômica é mais pronunciada, como em Marques (1991), Souto (2004), Silva (2006) e Oliveira Júnior (2003) e as aproxima de outros em que a maré meteorológica prescreve as condições hidrodinâmicas, como em Nietschmann (1989).

Entre as "águas baixas" e as "águas cheias" há períodos de transição percebidos onde "Quanto mais vai chegando perto do inverno, sempre vai crescendo mais a água" e "se continuá do jeito que vai cada vez mais baixa". Estes dois períodos de transição de "crescê" e de "baixá" água são marcados pelos "represos" que, como foi visto em 4.2, é gerado pelos ventos ${ }^{161}$ :

É, lá pra março-abril, lá pro lado do inverno as águas andam mais altas. Sabe por quê? Porque dessa época aí em diante o oceano anda mais crescido aqui na costa. Vai puxando mais pra rebojo, esses vento de inverno, entendesse, e aí já vai trocando a estação.(...). Agora, final de agosto-setembro, o inverno já tá treminando... qual vento tá dando mais? Esse aqui ó (nordeste). (...). Antão esse vento aqui (nordeste) que baixa água, sabias, que ele arrecua o oceano. Aí é só de manhã também que dá represo. Agora (final de agosto-setembro) até outubro-novembro dá represo todos os dia na barra. Enche de manhã e vaza de tarde. (Sindo, 40 anos, pescador artesanal).

Os "represos" representam momentos de transição opostos na etnocronologia estuarina: um que marca a transição das "águas baixas" do verão para as "águas altas" do inverno, nos meses de março e abril, geradas pelas mudanças na predominância dos ventos nordeste para o "rebojo" ('o oceano anda mais crescido'), enquanto o outro marca a outra transição, entre final de agosto e novembro, das "águas cheias" do inverno ('água da chuva') para as "águas baixas" do verão geradas pelo vento nordeste que "arrecua o oceano". Neste sentido, enquanto no represo do vento "rebojo" o "oceano vem à costa" e gera o início de um período de "águas cheias", porém salgada, ainda no verão, no represo subsequente o vento nordeste "baixa" as "águas cheias", porém "da chuva", portanto doce, ainda no inverno.

\footnotetext{
${ }^{161}$ Como foi visto no item anterior, há dois tipos de "represos": os "represos de água doce" que são gerados por "ventos de baixo" e altas descargas fluviais e os "represos de água salgada" que são gerados por "ventos de cima". No entanto, na etnocronologia estuarina há somente referências aos "represos de água salgada", embora, as características do "represo" que marca a transição do inverno para o verão assemelham-se aos "represos de água doce".
} 
Uma outra característica dos "tempos de represo", transição entre "águas cheias" e "águas baixas", é a ocorrência frequente de estratificação vertical de salinidade: "É, também tem essa aí: por cima é doce e por baixo é salgada. (...) ela endoça completo ou ela salga completo. É mais quando ela vem salgando no causo que ela tá doce ou as veiz que ela vem endoçando, entendesse" (Sindo, 40 anos, pescador artesanal). Em períodos em que o estuário tende a passar de um padrão de circulação com divisão de águas ('águas baixas') para aquele em que a água "corre na volta" ('águas cheias') ou vice-versa, há a possibilidade de uma estratificação vertical transitória das águas da Coréia.

Vale lembrar que, como foi discutido em 4.2.1, quando há descarga fluvial no rio São Gonçalo ('água de Pelotas') ocorre uma estraficação lateral de salinidade no corpo principal do estuário ('ali fora') também transitória e uma predominância de água doce no Saco do Arraial ('aqui dentro'). Nos demais momentos, a água se encontra "misturada", "endoçando" ou "se cortando", “doce" ou "cortada", ou seja, não há pronunciadas estratificações de salinidade.

É particularmente no período do "represo", transição do inverno para o verão, que ocorre os "repontes":

Agora em setembro, agosto em diante, o vento su-este dá aqueles reponte, que a gente chama, de água, né. (...). É a água. Reponte é aqueles que dá viração de água nesses mêis agora. (...). De enchente... virô de reponte. (...). A água enche: ela tá vazando, água doce, né, e ela vira na enchente, (...). Que é que tava vazando e virô na enchente. Uma aragenzinha de cima veio, sul... (Moisés, 45 anos, pescador artesanal).

O "reponte" é uma mudança momentânea ou permanente do regime de vazante provocado pela descarga fluvial para um regime de enchente provocado por "ventos de cima", com entrada de "pontas de água salgada", o que só pode acontecer na transição do inverno para o verão onde "a tendência é a água í se cortando (salgando)" (Delso, 40 anos, pescador artesanal).

Após os meses de março e abril, se sucede um período que é chamado de "calmaria de maio": "aquela época calma de maio, entendesse". Na verdade, a "calmaria" é um "sinal" apropriado do hiato existente no revesamento de dois ventos: 
mexe: 'Mexeu, mexeu cum o rebojo e num aguentô as ponta. Se entregô!'. (Evaldo, 36 anos, pescador artesanal).

A "calmaria de maio", contrariamente ao nome que lhe é atribuído, é o momento em que a mudança da predominância do vento nordeste para o rebojo ganha iminência, para a mudança, e eminência, no sentido perceptivo, máximas. Subsequentemente, a calmaria de um vento, que pode durar até um dia, é sucedida por outro, até que, depois desse período, como disse o Sindo, "é rebojo atrás de rebojo". Inversamente, no "tempo do represo", transição do inverno para o verão, a nova mudança na predominância dos ventos é colocada em oposição à primeira:

\begin{abstract}
Agora, de setembro em diante, (...), aí o nordeste é assim: ele vai vai vai até acalmá o tempo. Mas roda, roda uma semana de nordeste até acalmá o tempo. (...) e já não demora muito até o fim do dia as veiz pá, nordeste de volta. E... mais um tempão de nordeste! (...). É que nem de inverno: dá um dia de nordeste, o resto tudo rebojo. (...). É só um dia nordeste, no outro dia pá, rebojo. E agora o nordeste vai descontá, dá-le o troco. (Sindo, 40 anos, pescador artesanal).
\end{abstract}

Primeiro, na transição das "águas baixas" para as "águas cheias", o "nordeste provoca o rebojo", mas "não aguenta as ponta", e depois, na transição das "águas cheias" para as "águas baixas", "o nordeste dá-le o troco" ("Agora, de setembro em diante [...] roda uma semana de nordeste até acalmá o tempo. [...]. E agora o nordeste vai descontá, dá-le o troco').

Finalmente, há mais um "sinal de memória" que diferencia verão e inverno e que se faz presente na marcação do tempo do verão para o inverno e vice-versa:

É o calor que faz esses represo (de setembro a novembro). Em março-abril as águas vêm e voltam pra ficá cheia, dá muito rebojo, cumeça a esfriá e o oceano vem pra costa, se perparando pras águas alta do inverno, água da chuva, né. E agora, final de agosto-setembro, até outubro-novembro, as águas começam se cortando pras água baixa do verão. Isso se num chuvê. (Sr. Dino, 67 anos, pescador artesanal).

A fala do Sr. Dino contém todos os "sinais de memória" que marcam o verão e o inverno e seus períodos transicionais que foi discutido anteriormente (altura da água, ventos e chuvas) e suscita outros, o "calor" e o "frio". Obviamente, o verão é "calor" e o inverno é "frio", enquanto nos períodos transicionais do verão para o inverno "cumeça a esfriá" e no do inverno para o verão "é o calor que faz esses represo". No entanto, o “calor" e o "frio" estão incorporados nos ventos predominantes de cada estação ('dá muito rebojo, cumeça a esfriá e o oceano vem pra costa') e indicam mudança na 
predominância dos ventos: inverno predominância do "rebojo", vento frio, e verão predominância do nordeste, um vento "quente". Por isso "é o calor que faz esses represo" de setembro a novembro indicando a transição para o verão.

Em uma escala de tempo sazonal, os pescadores da Coréia identificam períodos longos de tempo em que as águas do "nosso mar" "correm mais" e em que "fica paradinha" gerados pelas forçantes estuarinas: "Mas tem época aí que a água fica paradinha: ela num corre nem pra um lado nem pra outro. Em certas época ela pega uma explosão desgramada" (Guega, 54 anos, pescador artesanal). Neste caso, a categorização também é construída entre "verão" e "inverno":

No verão, cum água salgada, muitas veiz ela guenta mais é parada. Quando ela anda baixa mesmo ela guenta uma carga de dia parada, no nível. (...). Quando tá cum água salgada cum Lua cheia na boca da noite as veiz enche, mas quase sempre corre parado. No inverno também, a água guenta um bucado de tempo cheia. Cheia, mai no nível aí. (Sindo, 40 anos, pescador artesanal).

As "águas baixas" do verão e as "águas cheias" do inverno é "tempo de água parada", enquanto na transição de uma estação para a outra:

No represo de abril-maio o vento é rebojo, né, ele tá empurrando o oceano pra dentro da barra, aí ela cresce. Tem o ameaço de tempo também: dá uma correnteza louca de enchente. O tempo tá ameaçado, né. Aí é por causa do oceano, né. E cum o nordeste, quando tem água doce lá em cima, ela cresce aqui também, aí ela pega força mesmo na vazante. (Sindo, 40 anos, pescador artesanal).

Os "represos", tanto na preparação para as "águas cheias" do "inverno" quanto na preparação para as "águas baixas" o "verão", provocam uma explosão de movimento nas águas da Coréia. Há, portanto, dois picos em que a "água guenta parada" e dois picos em que "as água vêm e voltam" para as "águas baixas" ou "altas". No entanto, a explosão de movimento de água do represo do verão para o inverno está mais associada ao regime de enchente estuarina ('as água vêm e voltam pra ficá cheia), enquanto a do inverno para o verão ao regime de vazante estuarina ('as águas começam se cortando pras água baixa') (ver intensidade de movimentação das águas na Figura 8).

Evidencia-se, consequentemente, que estes períodos de "represos" marcam transições tanto no "mar" como no "céu". Mais do que isso, sob o ponto de vista etnooceanográfico, reflete a interdependência entre a dinâmica da água e da sua 
principal forçante, o vento, e, do etnocronológico, expressa uma experiência de tempo que não se constrói com os "sinais de memória" dissociados. $\mathrm{Na}$ organização destes fenômenos no "mar" e no "céu", são construídas categorias com características opostas. Forman (1970) identificou um período de transição entre verão e inverno entre os pescadores do Ceará, chamado de "quaresma", e Marques (1991), entre os pescadores da Bahia, notou a percepção de períodos de transição entre verão e inverno: a "quaresma", entre março e maio, e o "tempo de viração", entre agosto e setembro.

Neste sentido, o verão e o inverno são constituídos de dois momentos cada um. O verão caracteristicamente é associado às "águas baixas", de novembro a fevereiro, e do período de transição para as "águas altas" do inverno, de março a maio, enquanto o inverno se constitui por um período de "águas cheias", de junho a final de agosto e início de setembro, e também por um período de transição para as "águas baixas" do verão, de setembro a novembro. Esta divisão de tempo, segundo a dinâmica etnooceanográfica, diversa da nossa divisão oficial do ano em quatro estações ${ }^{162}$, cria duas estações no ano, "verão" e "inverno", de 6 meses cada, com características opostas, simétricas e que, por isso, se balanceiam. No entanto, não só "inverno" e "verão" são tomados como categorias opostas, mas também períodos dentro deles ('represos') que se destacam em importância segundo a lógica das tradições coreanas. Marques (1991), na Bahia, observou apropriações do tempo a partir do mundo natural segundo a lógica da oposição binária. Nietschamann (1989), além disso, observou que esta lógica da apropriação do mundo natural a partir da oposição binária tornava-o "balanceado e simétrico" (: 67).

Apesar das intensas descargas fluviais ('chuvas') ocorrerem mais frequentemente no "inverno", como dito anteriormente, há variações entre os ciclos anuais ('Isso se num chuvê', 'dependendo do tempo, né, se cumeçá a chuvê não, mas se continuá assim do jeito que vai...'), o que torna este ciclo descrito acima, a partir das categorias "inverno cum chuva" e "verão de água salgada" "163, apenas uma das várias possibilidades de etnocronologia estuarina: a possibilidade tomada como padrão (Figura 8). Isto afasta a concepção de que a percepção de tempo cíclica dos coreanos é a repetição da mesma coisa, de algo sempre previsível, e aproxima da percepção de ciclo que permanece de certa forma aberto.

\footnotetext{
${ }^{162}$ Por isso, daqui em diante, as categorias nativas de verão e inverno serão utilizadas entre “"”.

${ }^{163}$ Como será visto mais adiante, no padrão etnocronológico o "verão" também pode ser "de água misturada".
} 


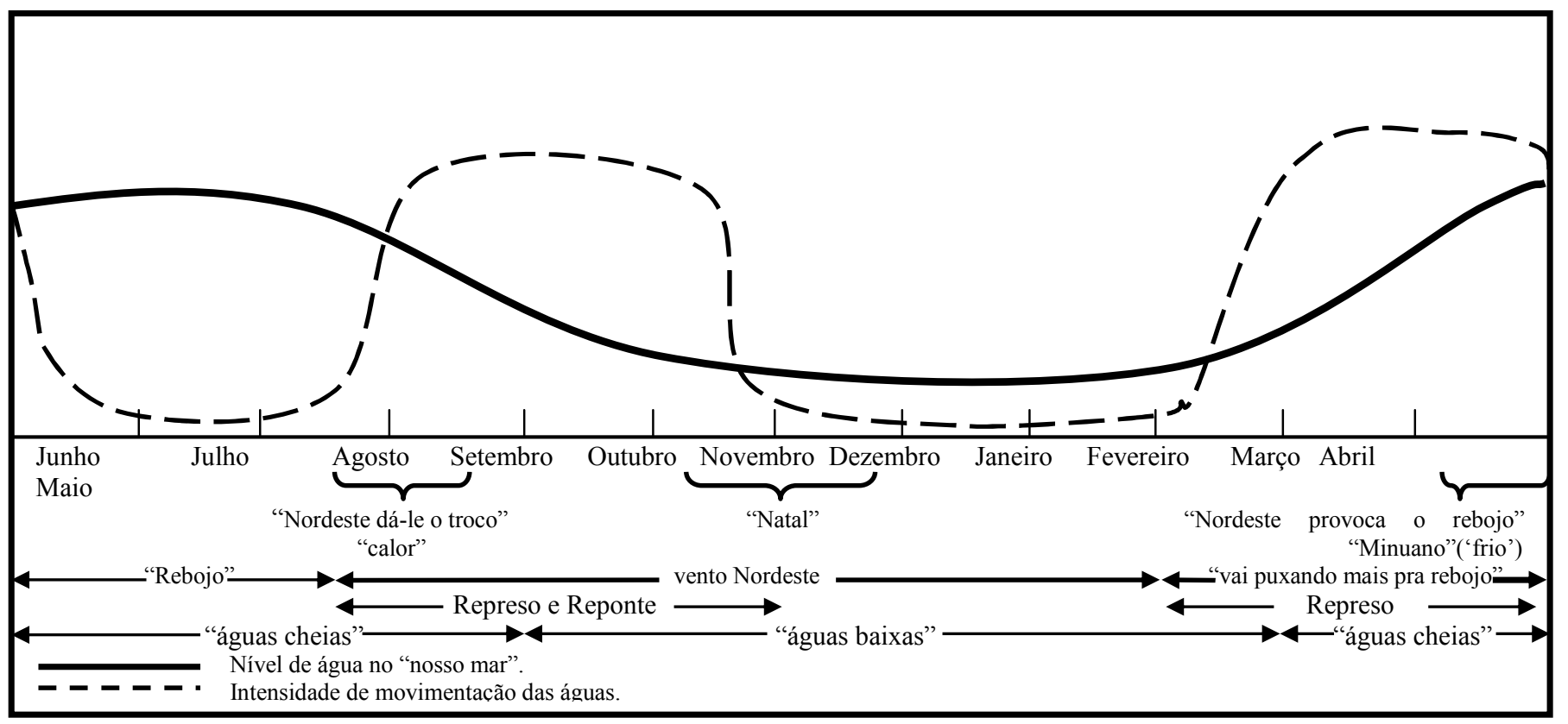

Figura 8 - O padrão etnocronológico: "ano de água misturada".

\subsubsection{As possibilidades etnocronológicas: "Que a água aqui tem muitas forma...".}

A forçante estuarina percebida como a segunda mais importante, as chuvas ${ }^{164}$, é a que gera, segundo o conhecimento ecológico tradicional, a maior parte das complexas possibilidades etnocronológicas. Devido consequências nas principais "safras" de pescados, que ocorrem no "verão", as chuvas no "inverno" são analisadas etnocronologicamente em duas categorias: o "inverno", que corresponde ao primeiro período do "inverno" fundado pelo "sinal" "frio" e abolido pelo "sinal" "calor", e a "primavera"165, fundada pelo "sinal" "calor" ou "tempo que cumeça a esquentá" e abolida pelo início de algumas "safras" de pescado que será visto na etnocronologia da pesca. Neste sentido, a "primavera" equivale a todo o "tempo do represo" mais o tempo necessário para o início das "safras de verão". Por isso, a discussão feita neste item não tem como finalidade a delimitação da "primavera", mas das possibilidades da etnocronologia estuarina através dos "sinais de memória" envolvidos na categorização da "primavera".

\footnotetext{
${ }^{164}$ Como as chuvas de que os pescadores falam não são aquelas que ocorrem localmente, o "sinal de memória" que "re-presenta" as chuvas em território coreano é a chegada de "pontas de água doce" e, de acordo com seu volume, é feita a projeção da quantidade de chuvas que ocorreu.

${ }^{165}$ Vale lembrar que a primavera é uma subcategoria de tempo que se insere tanto no verão como no inverno. Para efeito de análise, porém, será considerada uma categoria.
} 
O "padrão" etnocronológico estabelecido anteriormente é resultado do que é percebido pelos ilhéus como "bom" para a pesca devido a alguns temores de frustração de "safras de verão", sobretudo a de camarão, e ressalta-se que o "inverno cum chuva" não necessariamente é a categoria de maior frequência:

\begin{abstract}
Ah é, porque se passa o inverno seco, sem chuva, a gente já fica pensando assim: 'Pô, num chuveu no inverno, vai chuvê na primavera. Vai estragá a safra de camarão'. Que tudo tem medo o pescador (...). Porque aí senão vai ficá um exagero, vai seis meses de seca, sem chuva, inverno e primavera. Então, que nem eu te falei, tem que pegá bem escoado das águas doce e aí cumeçá a dá uns ventos de cima pra í enchendo de água salgada. (Sr. Rui, 60 anos, pescador artesanal).
\end{abstract}

De acordo com as expectativas e anseios dos pescadores artesanais a ocorrência de "inverno cum chuva" diminui a possibilidade de chuvas na "primavera", o que favorece a "safra de camarão".

Dentro da categoria "inverno cum chuva" existem duas subcategorias de "inverno": "Se num pegá a chuvê muito no inverno, num fazê muita altura de água lá (pra cima), essa água salgada entra pra nóis em agosto-setembro”. (Sr. Meca, pescadoragricultor, 68 anos); “Aqui no nosso mar o que temos pra essa época aí do inverno é o peixe-rei e o siri a não sê quando dá muita chuva e o pessoal tenha que procurá um peixe de água doce, nos banhado, né” (Sr. Rui, 60 anos, pescador artesanal). O “inverno cum pouca chuva" e o "inverno cum muita chuva" (ou 'inverno de água doce') também são fundados pelo "sinal" "chuvas", porém, no primeiro elas não se manifestariam na chegada de grande volume de água doce, o que favorece a entrada de "pontas de água salgada" em território coreano entre os meses de agosto e setembro encurtando o "tempo do represo", enquanto no segundo haveria a chegada em território coreano de grande volume de água doce, o que prolonga o período dos represos.

Por outro lado, em oposição ao "inverno cum chuva", há a categoria de "inverno seco": "Antigamente não vinha tanta água doce, as água doce eram menos, (...). Então o mar não adoçava tão facilmente e passava o inverno e verão salgado (...). As águas corriam o inverno quente passava na seca..." (Sr. Dino, 67 anos, pescador artesanal). Neste sentido, na ausência do "sinal de memória", chuvas, cria-se uma segunda categoria de "inverno", o "inverno que corre seco" que é o "inverno sem chuva" e, consequentemente, a água permanece "salgada" durante todo o "inverno". A partir do "inverno que corre seco" as possibilidades de chuva na "primavera" aumentam e, consequentemente, as altas descargas fluviais durante este período. 
A partir das categorias de "inverno", aumentam ou diminuem as possibilidades de chuvas na primavera. A possibilidade de ocorrência ou não de chuvas durante a "primavera", apropriada como um "sinal", gera duas categorias: "A primavera tem que corrê seca, se corrê chuvoso, estragou-se... não tem mais nada" (Amarildo, 40 anos, pescador artesanal). A "primavera corre seca"166 quando não há chuvas, ou poucas chuvas, durante a primavera. Vale ressaltar que o "padrão" etnocronológico adotado é composto por esta categoria de "primavera" já que não há "chuvas" durante o "represo". E a "primavera" que, em oposição a anterior, é categorizada a partir da ocorrência de "muitas chuvas", que é apropriada como um "sinal":

\begin{abstract}
A chuva, geralmente, vamo dizê, ela num pode chuvê muito (...) setembro, outubro. Porque se ela chuvê pro meio do inverno (primavera), depois que o tempo milhorá, ela pode voltá a salgá, vamo dizê, em tantos de dezembro (...). De outubro em diante num pode chuvê, muito num pode, porque aí, vamo dizê, chuvê em todo o estado ela vai, aqui é a saída, né, ela vai ficá sempre doce aqui. Então ela tem que chuvê mais cedo, vamo dizê, o caso que é pra dá tempo dela saí. (Sr. Zezinho, 60 anos, pescador-lavrador).
\end{abstract}

A expressão "muita chuva" é polissêmica: após o mês de setembro significa intensidade ('De outubro em diante num pode chuvê, muito num pode...'), mas se as "chuvas" se iniciarem antes de setembro ('se corrê chuvoso...') significa recorrência ao longo dos meses da primavera ${ }^{167}$. No entanto, ambos os sentidos guardam um continuum de experiência temporal que se materializa nos processos oceanográficos ('tem que chuvê mais cedo, vamo dizê, o caso que é pra dá tempo dela saí'): o tempo de residência da água doce no interior do estuário. Com regimes de chuvas intensos pósoutubro e/ou recorrentes durante a primavera não há tempo hábil para que as águas doces (água da chuva) se escoem para o oceano adjacente.

Ainda que não seja frequente, contrariando expectativas, há a possibilidade de se fundar o "inverno cum chuva" e subsequentemente a "primavera cum muita chuva": "Tem anos que passa inverno todinho cum água doce de apodrecê os capim todinho aí das praia de água doce. Pior que é!” (Sr. Dino, 67 anos, pescador artesanal). E também o "inverno seco" seguido de uma "primavera que corre seca": "as veiz que nem o inverno passado num endoçô. Lá de veiz em quando aparece um ano que ela num

\footnotetext{
${ }^{166}$ A "primavera que corre seca" pode ser chamada também de "primavera cum pouca chuva".

${ }^{167}$ Se o regime de chuvas não alcança classificação entre a recorrência e a intensidade pós-outubro, a primavera é considerada "seca".
} 
endoça. É só sê um ano de estiage que ela num endoça" (Sr. Zezinho, 60 anos, pescador-lavrador).

Como o "inverno" há três categorias de "verão". Uma delas é a que constituiu o primeiro "padrão" da etnocronologia estuarina: o "verão de água salgada" (Figura 8). No outro extremo tem-se um "verão" que as águas ficam "altas": "Ano de El Niño correu verão e inverno sempre água podre aí, verão e inverno de água doce. Água cheiona, sempre cheia. Era água da chuva, era muita chuva" (Evaldo, 36 anos, pescador artesanal). Neste caso em que no "verão" é caracterizado pelo "sinal" "muita chuva", as intensas descargas fluviais geram a categoria de "verão de água doce". Entre os dois extremos, mas também tendo a "chuva" como "sinal", é quando a água fica "meia misturada":

\footnotetext{
...que ele (o camarão) tumbéim gosta de verão cum uma água meia misturada, nem muito doce e nem muito salgada, uma água meia misturada... de pontas d'água, né, pontas d'água. (...). Água salgada demais, não é bom, e quando ela tá meia... pontas de água doce que vai e que vem. (Guega, 54 anos, pescador artesanal).
}

No verão quando dá chuva ela adoça, né. Aí melhora aqui. (...). Misturô, deu! (...) aqui se chuvê, se dé águas doce mesmo, assim não muita águas doce, aí a água fica meia misturada aí. (Gordo, 39 anos, pescador artesanal).

Neste sentido, quando as "chuvas" não são muito intensas e frequentes ("não muita água doce'), as descargas fluviais moderadas levam a Zona de Mistura estuarina (ZM) mais ao sul, próximo a Ilha dos Marinheiros ('pontas de água doce que vai e que vem') durante o "verão", o que gera um "verão de água misturada".

Qualquer uma das três categorias de "verão", como estação posterior ao inverno, resulta dos processos que dele decorrem: “o verão já num presta: chuvendo demais no inverno o verão também fica ruim" (Sr. Oswaldo, 76 anos, pescador-lavrador aposentado). Neste sentido, é estabelecido um continuum entre "inverno" e "verão" criando a categoria de "ano" de acordo com o "sinal de memória" que caracteriza as duas estações. Tanto o "sinal” "água doce” ('chuvas”):

No El Niño chuveu muito: a água se veio lá de cima, de Porto Alegre, chuveu muito naquele ano. (...). Em noventa e oito chuveu o inverno todo e o verão todo. Em noventa e oito entrô o verão aí que aqui mesmo a tua bota num apeiava. Onde nóis temo a tua bota num apeiava. E ficô assim inverno todo e verão todo. (Amarildo, 40 anos, pescador artesanal). 
Quanto o "sinal de memória" a "água salgada": "Qué vê: esse ano foi inverno e verão, o verão passado e inverno de água salgada... Foi um ano de água salgada" (Delso, 40 anos, pescador artesanal). O mesmo "sinal", "água salgada" (ausência de chuvas) e “água doce" ("chuvas'), no "inverno" e no "verão" funda um "ano de água salgada"168 (Figura 9) e "de água doce" (Figura 10), respectivamente.

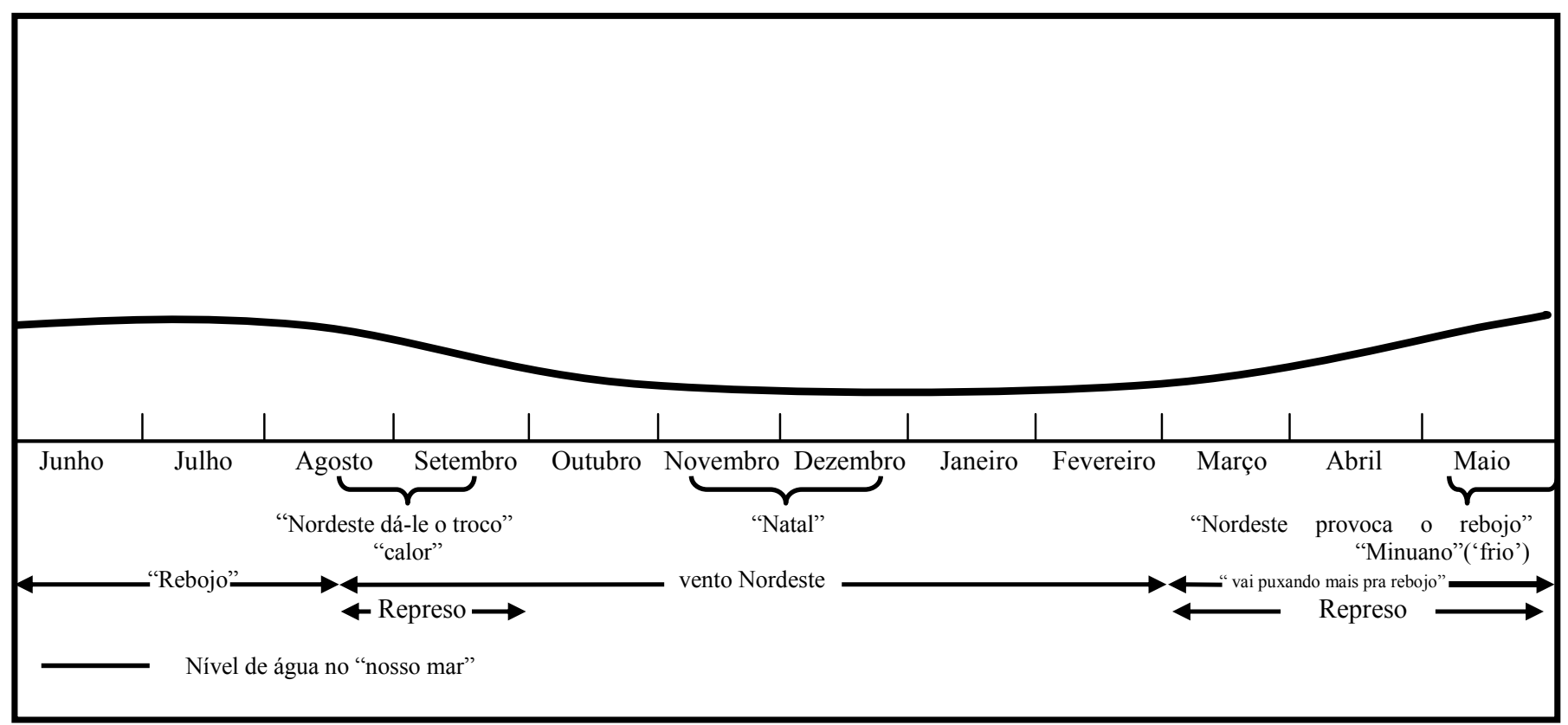

Figura 9 - As possibilidades etnocronológicas: "ano de água salgada".

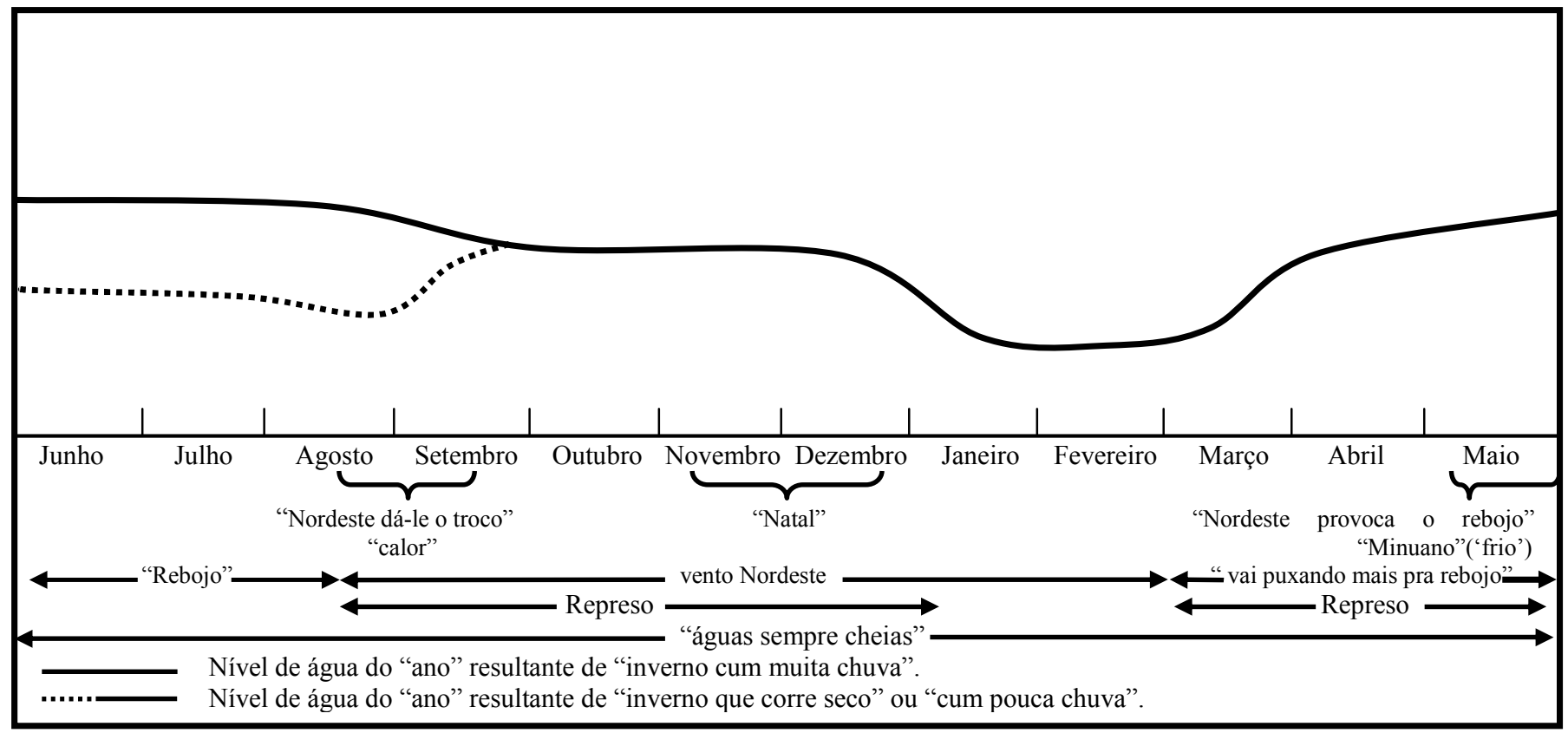

Figura 10 - As possibilidades etnocronológicas: "ano de água doce".

168 "Ano de água salgada" = "ano de água re-salgada". O prefixo "re-" carrega o significado de iteração, já que, neste caso, o "inverno" e o "verão" são "de água cortada". 
Novamente entre os dois extremos, "água doce" e "água salgada”, tem-se uma categoria que se interpõe:

Lá pra outubro tem que estancá (a chuva). Estancá pra dá evasão dois ou trêis mêis, (...). Aí, lá pro fim de novembro, início de dezembro, já começa a dá aquelas ponta de água salgada. É até milhó pra nóis, sabes. (...). Aí quando o ano é de água meia misturada. (Sindo, 40 anos, pescador artesanal).

A não-ocorrência do "sinal" "chuvas" a partir do mês de outubro sucedido pelo "sinal" "pontas de água salgada" a partir de meados do mês de novembro funda um "ano de água misturada", seja o "verão de água salgada" ou "de água misturada".

Vale ressaltar que o "ano de água misturada" é a categoria em que se enquadra o "padrão" etnocronológico (Figura 8), onde o "sinal" "pontas de água salgada" entre o final do mês de novembro e início de dezembro constitui um período ótimo para a safra de camarão em território coreano, como será visto na etnocronologia da pesca. Portanto, estes prazos correspondem mais aos anseios da comunidade do que limites naturais para as "águas se cortarem".

A transição do "inverno" para o "verão", período chamado de "primavera" pelos nativos, é o momento crítico para a ocorrência ou não de chuvas, que permite a entrada ou não de "pontas de água salgada", eventos que individualizam as estações e, consequentemente, os "anos".

A "chuva" não é a única forçante estuarina apropriada como um "sinal de memória" que influencia na construção de categorias de "inverno" e de "anos": "É, porque tem aquilo, né, a temperatura do tempo: tem anos que o calor vem mais cedo que outros assim como termina mais cedo que outros" (Sr. Zezinho, 60 anos, pescadorlavrador). Neste sentido, há entre os "anos" uma variação na predominância do vento nordeste ('calor') durante a primavera podendo trazer consequências na hidrodinâmica do "nosso mar":

Mas depois entra a primavera, (...). Se tivé o nosso mar cheio d'água aí, que a gente diz enchente, né, que anda sempre as praia tapada d'água, e dé muito vento sul, su-este, aí faz um paredão lá na boca da barra e num dá saída d'água. O vento sul, ele, na veiz de tirá, ele bota mais água ainda pra dentro. (Sr. Rui, 60 anos, pescador artesanal).

Associado e subsequente ao "sinal" "chuvas", a principal forçante estuarina, os ventos, sobretudo o vento sul e o "su-este", também contribuem para a manutenção das 
“águas altas" por impedirem a saída das "águas doces das chuvas" do "nosso mar" para o oceano durante a "primavera", aumentando as possibilidades do irrompimento e do "ano de água doce" ou do "ano de água misturada".

Quanto a uma terceira forçante estuarina, a maré astronômica, vale ressaltar que o "ano de água salgada" é o único período em que se mantém a mesma influência no "inverno" e no "verão": "A Lua manda muito. (...). No verão e no inverno, sempre. É que cum água cortada, cum pouca água, ela gosta mais de corrê cum mais força, né. Encontra menas água, ela corre cum mais força" (Sr. Meca, 68 anos, pescadorlavrador). Com a "água salgada inverno e verão" a Lua mantém sua influência no regime de enchente e vazante estuarina durante todo o "ano".

Inversamente, em "anos de água doce" a influência da maré astronômica seria dimininuída também durante o "verão": "Quando tem água doce essas Lua num mexe cum nada" (Sr. Dino, 67 anos, pescador artesanal). Assim como no "inverno de água doce", o "verão de água doce" também tem a influência da maré astronômica diminuída pela segunda mais importante forçante estuarina, a descarga fluvial.

Assim como o "verão" decorre dos processos do "inverno", este também decorre dos processos daquele como pôde ser visto nos "represos", que representam uma "perparação pro inverno", na descrição do ciclo etnocronológico "padrão". Neste sentido, o "tempo de águas salgadas" e "baixas" no "verão", "verão de água salgada" ou "meia misturada", pode ser encurtado ou prolongado em relação ao "padrão" etnocronológico trazendo consequências também para o "inverno".

O término precoce do "tempo de água salgada" pode ser fundado por um "sinal”, "muita chuva”: “...qué vê uma coisa: já teve ano que a safra findô no finzinho de abril, cum água doce, tapô tudo aí. Chuveu muito, em plena safra, desceu água de cima e a água de escoage do território de Pelotas..." (Sr. Zezinho, 60 anos, pescadorlavrador). Neste sentido, o "tempo de água doce" e "altas" que seria fundado pelas "chuvas" no "inverno", após o mês de maio com a chegada do "sinal" "frio", é antecipado através da ocorrência de "chuvas" antes ainda de maio. Neste caso, como será visto na etnocronologia da pesca, sepulta-se também o "verão" e funda-se o "inverno". 
Por outro lado, a não-ocorrência de chuvas pós-maio retarda o fim do "tempo de água salgada" e "baixa"169: "Se corrê o ano assim de água salgada vai sê bom pro peixe-rei. (...). Agora, o verão todo, e o inverno. Já mais pro fim pode endoçá que aí dá ingual, ele fica preso aí dentro e dá na água misturada daí” (Delso, 40 anos, pescador artesanal). Com o "sinal" não-chuva durante o pós-maio aumenta-se gradativamente as possibilidades de chuva que abolem o "tempo de águas salgadas" e "baixas". Diferente da antecipação do "inverno" pelas chuvas, o "verão" não sobrevém ao "inverno" com a não-chuva, já que o "frio", neste caso, é literalmente categórico: ele impõe o "inverno"170.

Há ainda a possibilidade do "tempo de água doce" e "alta" no verão, "verão de água doce", ser prolongado durante o "inverno": "No El Niño chuveu muito: a água se veio lá de cima, de Porto Alegre, chuveu muito naquele ano. (...). Em noventa e oito chuveu o inverno todo e o verão todo. (...). Imendô o outro inverno também cum água doce e alta" (Amarildo, 40 anos, pescador artesanal). Portanto, é possível que um "verão de água doce" dê origem a um "inverno de água doce”.

Qualquer uma destas três possibilidades de passagens do "verão" para o "inverno" construídas pelos "sinais de memória" que individualizam cada categoria de estação marca o reinício de um "ano", o eterno retorno do ciclo etnocronológico do “nosso mar" ('Cumeça tudo de novo').

Os "sinais de memória" elencados que "estabelecem prazos" e individualizam o tempo são materializados na água ('aqui o que manda mais é o problema d'água' Sr. Dino, 67 anos, pescador artesanal), como os "anos", por exemplo: “ano de água salgada", "ano de água doce” ou "ano de água misturada".

No entanto, o contexto é gerado pela associação com outros "sinais de memória" (ventos, frio, lua, etc.) que ganham significado dentro de determinado contexto e ao mesmo tempo em que cada contexto vai sendo construído. O tempo está sempre em construção. Segundo Kagame (1975), apenas o sinal que individualiza um evento não funda um tempo. No estudo da percepção empírica do pensamento Bantu,

\footnotetext{
${ }^{169}$ Vale lembrar que, devido a predominância do vento rebojo no inverno, as águas não são tão "baixas" quanto a do verão, segundo a estrutura cognitiva dos nativos.

170 Devido à influência do "frio" no padrão migratório dos recursos pesqueiros durante o "inverno", se o "inverno" até sua chegada não foi fundado, ele, independente de outros fatores, o impõe.
} 
ele evidencia a construção do tempo para a ocorrência de cerimônias fundadas pela Lua nova: “...pois a Lua mesmo não cria as circunstâncias que caracteriza a seriação do seu curso" ao passo que se necessita das "interferências das estações" (:124). Portanto, o marco natural deve ser contextualizado num conjunto de manifestações concretas da natureza característicos do tempo que funda.

Do ponto de vista hidrodinâmico, a ordenação e categorização dos "anos" segundo o "problema d'água" estuarino, é uma forma de manter a dinâmica ambiental dentro de um espectro "normal" de variação, ou seja, domesticar o tempo através do espaço em movimento. Neste sentido, conhecer o tempo é uma forma de "territorializá"lo, assim como em Nietschmann (1989).

A dinâmica ambiental fornece um espectro de possibilidades temporais apropriadas e categorizadas ('anos de...', 'verão de...', 'inverno de...'). Ainda que elas sejam densamente conhecidas, segundo Kagame (1975) e Panikkar (1975), o tempo, ainda não "selado", é apenas contigência e por isso possibilidade também de imprevisibilidade.

No caso estudado, a contigência e a imprevisibilidade podem ter duas implicações, uma sobre os "tempos" conhecidos e outra sobre os não-conhecidos. Primeiro que, como os "anos" são diferentes (três categorias), a abolição de um para a fundação de outro não necessariamente é a fundação da "mesma coisa", mas a possibilidade de fundação de algum deles. A recorrência de fenômenos constrói qualquer um dos "tempos" conhecidos que se intercalam ao longo dos anos. Mas a percepção do tempo é de retorno ('Cumeça tudo de novo') e não linear. Neste sentido, o intercalamento dos "tempos" ao longo dos anos serve como um eixo em espiral em torno do qual giram os ciclos. Portanto, não apenas o espaço é percebido tridimensionalmente, mas também o tempo.

As contingências e incontingências temporais, neste sentido, assemelham-se ao tempo percebido em espiral para o povo muçulmano (GARDET, 1975) e para o povo Bantu (KAGAME, 1975). Para este último o tempo é representado por um

...eixo central em volta do qual giram os ciclos, à semelhança de uma espiral, que dá a impressão de um ciclo aberto. Cada estação, cada geração a iniciar, (...) volta à mesma vertical, mas num nível superior. Em outros termos, eles não voltam ao mesmo ponto no espaço nem ao mesmo instante... (: 127). 
O "cumeça tudo de novo" guarda, neste sentido, o significado de abolição do antigo já construído, conhecido e, consequentemente, devidamente categorizado, pelo outro ainda não construído e, consequentemente, aberto às contingências, às possibilidades, ainda que conhecidas.

Segundo que as categorias de "tempo" construídas, ou melhor, a experiência temporal do grupo, não torna cognoscível todas as possibilidades e variáveis dinâmicas de que a natureza dispõe. A apropriação das surpresas, no entanto, é mediada pela lógica da experiência temporal do grupo. Disso resulta que, sejam quais forem as recorrências de fundo hidrodinâmico, elas serão enquadradas numa das três categorias de anos, ainda que não correspondam exatamente às características daquele "ano".

A etnocronologia estuarina é a materialização do tempo em corpos materiais abióticos que perfazem a interface "mar"/“céu” (ventos, chuvas, Lua, água, etc.). Porém, a interface "mar"/“céu" foram situados no tempo com ênfase na dinâmica da água, já que, além da perspectiva etnoocenográfica, ela serve inconteste de subsídio às tomadas de decisão na pesca: “Aqui o que manda mais é a água, a pescaria nossa aqui. Eu, quando eu pescava mesmo, (...) eu manobrava mais é cum a água” (Sr. Dino, 67 anos, pescador artesanal).

Assim, pode-se dizer que, a construção do espaço-tempo tridimensional, é um mecanismo do homem de inserção adaptativa no mundo "real" a partir do mundo percebido. Neste sentido, o "inverno..." e o "verão de...", e todas as suas combinações possíveis para a construção dos "anos de...", e os "anos de..." constituem contextos a partir e dentro dos quais se dá a movimentação, as tomadas de decisões e ações de "quando", "onde" e “como" pescar no "nosso mar". Segundo Steward:

\footnotetext{
O homem entra no cenário ecológico... não apenas com um outro organismo que está relacionado com outros organismos em termos de suas características físicas. Ele introduz o fator superorgânico da cultura que também afeta e é afetada pela teia total da vida (1955: 31$)$.
}

A partir desta proposição de Steward, tem-se que os "anos de...", e seus constituintes fundamentais ('inverno...' e 'verão de...'), compõem “cenários” que o homem organiza para sua ação ordenada e adaptativa na natureza.

A partir das categorias de tempo construídas na etnocronologia estuarina, será formulado o calendário de pesca na Coréia. Ambos articulados, etnocronologia 
estuarina e calendário de pesca, estruturam os cenários para as tomadas de decisões e ações na pesca.

\subsection{Etnocronologia da pesca coreana}

A construção do tempo das águas da Coréia ainda não está terminada. Ainda falta a descrição da etnocronologia da pesca coreana. Para este fim, recorre-se ao conhecimento ecológico tradicional de certos referenciais que prenunciam a recorrência de fenômenos materiais da natureza, os "sinais de memória". Diferente da etnocronologia estuarina, na etnocronologia da pesca, além dos "sinais de memória" que "estabelecem prazos", há aqueles que engendram ações que, por sua vez, segundo Kagame (1975) e Panikkar (1975), condensam o tempo percebido. Retomando Leite (2007):

\footnotetext{
"...marcos esses que estabelecem prazos e conexões de anterioridade e posteridade no continuum da consciência pessoal e coletiva. (...). Aí, a experiência e o conceito de tempo ficam essencialmente denotados pelos movimentos entre os membros da comunidade, assim como entre os eventos, e entre aqueles e estes últimos" (: 116).
}

São, portanto, duas categorias de "sinais de memória" construídas a partir da perspectiva de Leite (2007): os que "estabelecem prazos" e os que se articulam aos prazos estabelecidos e geram o movimento entre os membros da comunidade.

Articulados às categorias de tempo construídas na etnocronologia estuarina, os marcos ('sinais de memória') que "estabelecem prazos", ou seja, que marcam divisões no tempo tradicional para as sucessivas safras, constituem o calendário tradicional da pesca na Coréia.

O calendário tradicional, por sua vez, é uma relação entre um ciclo de atividades e um ciclo conceitual e os dois não estão isolados. $\mathrm{O}$ calendário está ancorado ao ciclo de mudanças ecológicas (EVANS-PRITCHARD, 2007). Neste sentido, o calendário é o conceito de tempo que serve de contexto/cenário para a "movimentação dos membros da comunidade" e de outros "sinais de memória" ('eventos') que se engendram, dentro das safras (prazos estabelecidos), e que também geram a movimentação dos membros da comunidade. Estes "sinais de memória" que se 
contextualizam no calendário, em cada safra, constróem o que Chesneaux (1989: 29) chama de "maturação de uma situação" para as ações. À medida que a ação ('movimentação dos membros da comunidade') condensa o tempo percebido vai construindo a "quarta dimensão" do território grupal coreano: o tempo. O conjunto destes "sinais" que forma uma categoria diversa à que "estabelecem prazos" será discutida em "tomadas de decisões e ações".

\subsubsection{Calendário: "Mês a gente pouco usa".}

Todas as culturas pré-modernas possuíam calendários (GIDDENS, 1991). O cálculo do tempo, por ser um princípio ordenador da percepção coletiva de tempo (GOUREVITCH, 1975), constituía a base da vida cotidiana e sempre vinculou espaço e tempo (GIDDENS, 1991).

Na Coréia, a ordenação do tempo, assim como a dos compartimentos espaciais do território, é feita sob a lógica da oposição binária onde os simétricos se balanceiam e os "sinais de memória", dentro de um espectro de possibilidades e de "prazos", se repetem. Neste sentido, o tempo dos pescadores artesanais e dos pescadores-lavradores da Coréia pode ser caracterizado como tradicional e não se difere do tempo cíclico e não-rígido de outros pescadores de outras partes do Brasil (CUNHA e ROUGEULLE, 1989; WOORTMANN, 1992; MALDONADO, 1993; CUNHA, 2007) e do Mundo (NIETSCHMANN, 1989), embora as recorrências materiais que fundam e abolem um tempo sejam próprias do ambiente e da cultura locais. A base local das recorrências materiais também é atribuída por Giddens (1991) às culturas pré-modernas quando caracteriza a vinculação "tempo e lugar".

Dentro do ciclo das atividades pesqueiras, o "ano" é considerado uma unidade cíclica que perfaz as sucessivas safras pesqueiras até que, dentro das possibilidades possíveis, se repita ou não a safra característica de um tempo.

A divisão em estações é a primeira grande divisão temporal feita entre opostos dentro do "ano": "A gente conhece aqui o verão e o inverno" (Guega, 54 anos, pescador artesanal). Seja no mesmo Estado do Rio Grande do Sul (ADOMILLI, 2007), como em

outras partes do Brasil (CUNHA, 1987; OLIVEIRA JÚNIOR, 2003), o "verão" e o “inverno" é uma divisão comum do ciclo anual adotada pelos pescadores. 
Porém, se o tempo tradicional é cíclico e não-rígido, a divisão das estações não é dada por um horário exato que marca seu início e seu fim. As estações são construídas assim como as dos ilhéus de Torres Strait:

\begin{abstract}
As estações não são rigidamente fixadas em datas, mas por um padrão sequêncial que pode ser previsto e verificado por observações do ambiente como as condições da superfície do mar, direção da migração de certas espécies de aves, redistribuição de peixe, tartaruga e peixe-boi e ventos. (NIETSCHMANN, 1989: 67, tradução nossa) ${ }^{171}$.
\end{abstract}

No caso da pesca da Coréia, a construção das estações, assim como suas delimitações, por uma sucessão de "sinais de memória", têm como base a articulação das categorias de tempo formuladas na etnocronologia estuarina com as sucessivas safras características de cada estação, as "safras de verão" e as "safras de inverno". Ou seja, as estações são os resultados da confluência do ritmo estuarino com o ritmo biológico percebidos das espécies pescadas em território coreano.

No entanto, não se faz necessário descrever todas as "safras de verão" e "de inverno" para construir o calendário de pesca e a etnocronologia da pesca coreana. Foi escolhida uma safra que represente cada estação ('inverno' e 'verão') e uma que perpassa todo o "ano" e que juntas teçam o conhecimento que fundamenta o calendário, as tomadas de decisão, a diversidade de relações de posse que se fundam com os pesqueiros e a dinâmica territorial grupal.

No próximo item serão descritos aspectos gerais das "safras de verão" e "de inverno" seguido das safras que as representam, bem como da representante da safra que "dá o ano todo", como subsídios à construção do calendário de pesca.

\title{
4.4.1.1. As safras de verão
}

No "verão", três recursos pesqueiros são característicos desta estação: tainha, siri e camarão, embora tainha e siri sejam pescados também no "inverno", porém em menores quantidades e a tainha em menor tamanho. Não são todas as categorias de "verão" que as condições ambientais favorecem a pesca dos três recursos. O camarão

\footnotetext{
171 "The seasons are not rigidly fixed to calendrical dates, but instead follow a sequential pattern that can be forecast and verified by such environmental observations as sea surface conditions, migratory bird species and flight directions, the redistributions of fish, turtle and dugong and winds".
} 
ocorre apenas no "verão de água salgada" ou "de água misturada" e a tainha, assim como o siri, ocorre em qualquer categoria de "verão". Neste sentido, o camarão será tomado como o representante do "verão", já que é o único que ocorre apenas nesta estação, e a tainha como do "ano todo", pois, mais do que o siri, ilustra momentos do ciclo anual em que há permanência "aqui dentro" e saídas "ali pra fora".

O camarão, o siri e a tainha são os pescados de maiores abundâncias e que alcançam os maiores preços de mercado, transformando o "verão" na principal estação do "ano" para os pescadores especialistas em qualquer um dos três recursos.

Os "sinais de memória" que "estabelecem prazos" no verão indicam dois momentos do ciclo migratório dos pescados: a "entrada" e a "saída" entre o oceano e o estuário e a saída de "peixes" do território coreano para "lá pra cima". Silvano et al (2006) também descreve como uma categoria nativa o comportamento migratório de alguns pescados entre o oceano e o estuário. Já a migração entre "cabeceira" e "baixo" estuário foi registrada por Seixas e Berkes (2003), segundo o conhecimento tradicional de pescadores, para as mesmas espécies de tainha e de camarão que ocorrem no estuário de Ibiraquera (SC).

As entradas no estuário, segundo os pescadores, têm três funções: para se “criá" (crescer), caso do camarão e da tainha; para "largá as ova" (desovar), caso da corvina, e para "tirá produção" (reproduzir) e "largá as ova", caso do bagre e do siri ${ }^{172}$. Já a saída ocorre para desova, caso do camarão ${ }^{173}$ e da tainha ${ }^{174}$, ou após a desova, caso do bagre e da corvina. No caso do siri, não há menção de sua saída para o oceano depois que entra no estuário já que ele "cria" (cresce), "produz" (reproduz) e desova "aqui dentro" e em outras partes do estuário em qualquer uma das categorias de estação. Em Kalikoski e Vasconcellos (2005) é encontrado um modelo em que a dinâmica da migração dos recursos pesqueiros entre o estuário e a plataforma continental está associado à desova, recrutamento, crescimento e reprodução.

Neste sentido, os recursos pesqueiros das safras de "verão" cumprem apenas parte do seu ciclo de vida no estuário, com exceção do siri e da tainha que, segundo os pescadores, também “cria aqui mesmo". Portanto, mesmo que a tainha e o siri não

\footnotetext{
${ }^{172}$ Como será visto nas tomadas de decisão, o siri "dá entrada do oceano" não apenas para se reproduzir, mas em outros momentos da safra ele "dá entrada" com "ventos de cima".

${ }^{173}$ Muitos pescadores não acreditam que a arriada do camarão signifique sua saída para o oceano. Alguns outros acreditam na sua saída, mas não na sua desova no oceano. Para estes o camarão desova no estuário. ${ }^{174}$ Todos acreditam que a desova da tainha ocorre no oceano, porém acreditam que em alguma parcela ela desove também no estuário durante a corrida reprodutiva ('já vem desovando').
} 
migrem do oceano para o estuário, como nos casos da "primavera cum chuva", as "safras de verão" e "de inverno" são fundadas com o que está dentro do estuário.

A entrada no estuário ocorre na "primavera", entre setembro e dezembro, com picos de entrada entre outubro e novembro. No entanto, estas entradas dependem da ocorrência de "ventos de cima" e de chuvas no "inverno" e na "primavera": se "não chover" no inverno ('inverno seco') e na "primavera" ('primavera que corre seca'), estas entradas ocorrem já a partir de agosto e setembro, enquanto "se chuvê" no inverno ('inverno cum pouca chuva') e se a "primavera corrê seca", estas entradas são sucessivamente adiadas em função da "força de água doce lá pra cima". Por outro lado, se a primavera for "cum muita chuva" não há "entrada do oceano" de recursos pesqueiros. Vale ressaltar que, para a ocorrência de entradas de pescado, é necessário "ventos de cima", sobretudo sul e "su-este", após a vazão da maior "força de água lá pra cima" e a subsequente entrada de "pontas de água salgada". Kalikoski e Vasconcelos (2005) analisaram o padrão migratório dos mesmos pescados, segundo o conhecimento tradicional de pescadores do estuário da Lagoa dos Patos, com exceção do siri, e notaram forte influência do regime de chuvas e da intrusão de água salgada para a ocorrência de todas as safras.

No caso do camarão, os "prazos" de safra ficam mais tênues na ocorrência de um "inverno seco e quente" quando se pesca camarão "aqui dentro" também no “inverno", embora em menor abundância do que no "verão". Kalikoski e Vasconcellos (2005) observam que os invernos quentes também são favoráveis à pesca do camarão, embora nada mencionem a respeito da ocorrência de chuvas.

Há dois períodos de saída do estuário para o oceano. O primeiro movimento migratório, representado pela corvina e pelo bagre, se é "primavera que corre seca" ocorre até dezembro ('natal'), mas se é 'primavera cum muita chuva', porém com chuvas após o período de entrada destes pescados, o retorno para o oceano ocorre antes de dezembro; o segundo, representado pela tainha e pelo camarão, é a migração reprodutiva nos meses de abril e maio, com possibilidades para junho se é "verão de água salgada" ou "de água misturada" ou antes, "se chuvê" e/ou com ventos noroeste. A partir daí, inaugura-se um “inverno". Kalikoski e Vasconcelos (2005) também registraram para os mesmos pescados estes dois momentos de migração, embora o bagre e a corvina se extendam até o início do verão (janeiro e fevereiro), a tainha tenha sua entrada no estuário a partir de janeiro e não haja menção à "arriada do camarão". De 
acordo com McGoodwin (1989), os pescadores "libres" de estuários do México descrevem os "golpes" de camarão que seriam a migração do interior do estuário para o oceano em "ondas" a partir da confluência de diversos fatores ambientais: o quarto crescente ou minguante, altas precipitações pluviométricas e uma intensidade de fluxo de maré moderado.

A diferença entre o "verão de água salgada" e "de água misturada" é na quantidade e qualidade dos pescados que permanecem no "nosso mar" durante as safras. No "verão de água salgada" os pescados tendem a migrar "lá pra cima" gerando uma baixa biomassa e a permanência de pescados considerado de pequeno tamanho no "nosso mar". Ao contrário, no "verão de água misturada" os pescados permanecem maior tempo em grande biomassa e em maior tamanho no "nosso mar". Em Seixas e Berkes (2003), para os pescadores estuarinos da Bahia também é comum a migração de grandes camarões para o interior do estuário.

Dentre as várias possibilidades e articulações de categorias de estações ('invernos' com 'verões') que resultam em três categorias de "anos", conforme foi visto em 4.3, pode-se vislumbrar três cenários aos dois padrões migratórios descritos acima (entrada e saída do estuário e migração 'lá pra cima').

Em "anos de água salgada" a migração do oceano para o estuário ocorre entre agosto e setembro e a saída do estuário ocorre com a corrida reprodutiva nos meses de abril e de maio, podendo a saída ser estendida ou antecipada. Porém, no "nosso mar" em função da migração de grande biomassa dos pescados "lá pra cima" ocorre a escassez de pescado na Coréia antes, mesmo que ocorra a migração reprodutiva do estuário para o oceano e a presença de pescados considerado de pequeno tamanho.

Em "anos de água misturada" a migração do oceano para o estuário é protelada, em função da "força de água doce lá pra cima", com "prazo" máximo de ocorrência até o mês de dezembro e a saída do estuário também ocorre nos meses de abril e de maio, podendo a saída ser estendida ou antecipada. Além do início de safra mais tardio, a diferença em relação ao "ano de água salgada" é o maior tempo de permanência dos pescados em grande biomassa e em maior tamanho no "nosso mar" devido à ZM próxima ao "nosso mar".

Em "anos de água doce” o processo migratório entre oceano e estuário e do "nosso mar" para "lá pra cima" não ocorre ou ocorre de forma relativamente 
insignificante possibilitando apenas a pesca de tainha e de siri e em menor quantidade e tamanho.

Deve-se ressaltar, no entanto, que o "ano de água salgada" e o "ano de água doce" são possibilidades de cenários construídas ao cenário padrão: o "ano de água misturada".

Silvano et al (2006), pontua que para os pescadores o padrão geral de migração entre o estuário e o oceano ocorre em função de fatores climáticos e marés. Miller (2005) também observa a existência de três categorias de uma "estação" segundo a ocorrência de chuvas na região estuarina de Guararaíras (RN): 'seca', 'com pouca chuva' e 'com muita chuva'. A "estação seca" e "com pouca chuva" tinha efeitos considerados "não preocupantes" nos recursos pesqueiros, enquanto que a "estação cum muita chuva" gera escassez de pescado.

A seguir serão construídas as possibilidades e os "prazos" para as "safras de verão", representada pela pesca do camarão, e para a pesca de "verão" das safras que “dá o ano todo", representadas pela tainha.

\subsection{O camarão}

De longe, a pesca de camarão na Coréia é a economicamente mais importante e goza de uma longa tradição pesqueira e, talvez por isso, a densa experiência temporal fundamenta a utilização densa e sistemática de diversos "sinais de memória". Ao passo que os sinais vão se excluindo, complementando e/ou sucedendo, ou seja, se conformando, as incertezas perdem força e o tempo ainda contigente dá lugar ao irrompimento de um tempo, neste caso a fundação ou não da safra de camarão. Neste sentido, o início da construção da safra do camarão se dá a partir da "primavera", quando a observação sistemática de vários "sinais de memória" geram expectativas sobre a safra de camarão, entre eles as "chuvas" "175:

Pra tê uma boa safra de camarão precisa de uma primavera cum pouca chuva. Até que inverno chova té bastante, né, mas depois entra a primavera, é três meses de estação, né, então naqueles três meses correndo um tempo de pouca

\footnotetext{
175 A observação das chuvas, no entanto, se dá indiretamente através da chegada de "pontas de água doce" e as previsões do tempo nas TVs e rádios. Como foi visto em 4.2, não são as chuvas locais que causam as maiores descargas fluviais na Lagoa dos Patos, mas as chuvas em "Pelotas e "lá pra Porto Alegre", ou seja, "lá pra cima".
} 
chuva, (...), aí naqueles três meses dá tempo das águas se escoa, né, que chuveu de inverno, e se prepará pra uma boa safra de camarão. (Sr. Rui, 60 anos, pescador artesanal).

A previsão da safra de camarão é feita a partir de duas categorias de "primavera" fundadas a partir de um "sinal", as chuvas: uma "primavera que corre seca"176 e a "cum muita chuva"177. Na primeira o contexto é favorável à ocorrência da safra de camarão, enquanto na segunda o contexto é desfavorável.

Com o propósito de prever a ocorrência de chuvas durante os três meses da "primavera", a "Lua nova" do início da primavera é apreensivamente observada:

Noventa dias, a Lua vai manobrá cum o tempo, noventa dias: toda as volta de Lua chovendo. Agora tu vê: tem outubro, novembro, dezembro... é, até dezembro. É a decisão! É a nova, né, sempre a primeira Lua é nova, né. É a primeira volta da Lua nova. Mas aí vai chuvê todas: aí quando ela faz volta, chove. Passa dois-trêis dia bom, quatro, cinco, e depois chuva de novo. E quando chove, chove mesmo. Aí em todas as Lua chove. Que nem esse mês agora (setembro), agora tem chuvido, né: passa dois dia sem chuva e quatro dia de chuva. E assim vai sê. E tu vê a altura de água que tá aí ó, a água num salgô mais, sempre doce. E se encontrá a outra Lua nova assim vai continuá doce, sendo doce num dá nada. (Sr. Dino, 67 anos, pescador artesanal).

A primeira Lua nova da "primavera" (a de outubro), segundo o conhecimento ecológico tradicional dos pescadores coreanos, prenuncia chuvas durante toda a estação da "primavera" ("Noventa dias, a Lua vai manobrá cum o tempo, noventa dias [...]. Agora tu vê: tem outubro, novembro, dezembro...'). Se chover na "primeira volta da Lua nova", vai chover em "toda volta de Lua" até o mês de dezembro, limite temporal para a entrada no estuário, e no "nosso mar", das larvas de camarão ('...é, até dezembro. É a decisão!'). A partir deste limite se abre uma das duas possibilidades: ter ou não safra de camarão. Por isso, a primeira Lua nova da "primavera" sendo "chuvosa" cria expectativas negativas quanto ao "tempo potencial" que pode ou não irromper na safra de camarão ('Aí em todas as Lua chove. Que nem esse mês agora (setembro), agora tem chuvido, né. [...]. E tu vê a altura de água que tá aí ó, a água num salgô mais, sempre doce. [...] sendo doce num dá nada').

Portanto, se for inaugurada uma "primavera cum chuva" não há possibilidades de ocorrência de safra de camarão. Assim, inaugura-se um "verão de água doce" ou um

\footnotetext{
176 "Primavera que corre seca" = "Primavera cum pouca chuva".

177 "Primavera que chove" = "primavera cum muita chuva". Como foi visto em 4.3, a não-ocorrência de chuvas está diretamente relacionada com a categoria "águas baixas", que é imprescindível para a ocorrência da safra de camarão.
} 
"ano de água doce" quando se funda a safra de siri ou de tainha, dependendo da especialidade do pescador.

Por outro lado, como foi visto na etnocronologia estuarina, a "primavera" irrompe como resultado do "inverno". $\mathrm{Na}$ categoria descrita anteriormente de "primavera cum muita chuva", não importa qual seja o "inverno", pois as consequências para a safra de camarão serão determinadas pelo "sinal" "chuvas" durante a "primavera cum muita chuva". Porém, se a "primavera corre seca", as consequências para a safra de camarão serão dadas pelo "inverno".

Se o "inverno" for "cum muita chuva", com o término de chuvas no máximo em outubro, a entrada de camarão ocorre, até o fim de dezembro ('natal'):

A chuva, geralmente, vamo dizê, ela num pode chuvê muito (...) setembro, outubro. Porque se ela chuvê pro meio do inverno, depois o tempo milhorá, ela pode voltá a salgá, vamo dizê, em tantos dezembro e ainda dá uma boa safra de camarão. (Sr. Zezinho, 60 anos, pescador-lavrador).

Neste sentido, se o "inverno" fundado for "cum muita chuva" associado à “primavera que corre seca" ocorre a entrada de "pontas de água salgada" em dezembro e aumenta a possibilidade de fundação de um "verão de água misturada" ou de um "ano de água misturada" no "nosso mar"178: "Aí quando a água é meia misturada, dá mais camarão aqui nesses sacos aqui. Só é mais ruim já í pra fora pra lagoa. Pra lagoa já é mais ruim" (Sindo, 40 anos, pescador artesanal).

Ainda que o "inverno" seja "cum pouca chuva", associado à "primavera que corre seca", as consequências são semelhantes ao "inverno cum muita chuva" favorecendo a safra de camarão:

Se num pegá a chuvê muito, num fazê muita altura de água lá (pra cima) no inverno, essa água salgada tem que entrá pra nóis de agosto-setembro cum rebojo, sul. De setembro em diante pega-a-entrá essa água, quando é lá pra dezembro, a vinte-vinte e cinco de dezembro pega-a-aparecê um camarãozinho. (Sr. Meca, 68 anos, pescador-lavrador).

\footnotetext{
${ }^{178}$ Sobre a construção do "verão de água misturada", do "ano de água misturada" e sobre a preferência dos pescadores por estas categorias de tempo para a safra de camarão ver etnocronologia estuarina.
} 
O "inverno cum pouca chuva" permite a entrada de água salgada no início da "primavera", a partir dos meses de agosto e setembro, e com início da safra de camarão já em dezembro ('lá pro natal') ${ }^{179}$.

Somente dentro do contexto do "inverno cum chuva"180, devido ao tempo de residência da água doce no interior do estuário, que o processo de entrada de "água salgada" ocorre num período considerado ótimo para a safra no Saco do Arraial, entre os meses de novembro e dezembro, mantendo a "água misturada", o que impede que o camarão migre do Saco do Arraial para "lá pra Lagoa".

Durante a "primavera que corre seca" resultante do "inverno cum chuva", três outros "sinais" se articulam na construção das expectativas da safra do camarão: os "ventos de cima" e os "ventos de baixo"181 e as "pontas de água salgada":

Pra tê uma boa safra de camarão tem que salgá a água, né, que o forte da safra de camarão é a água salgada, tem que entrá águas do oceano porque a larva mesmo vem do oceano. Pra salgá a água, (precisa) chuvê pouco na primavera pra entrá água salgada, né. Aí dá os ventos nordeste, pega-tirando aquela água doce que chuveu no inverno e também num vai acumulá mais água doce que num vai chuvê na estação da primavera e aí vai baixando a lagoa aí, vai cumeçando a entrá pontas de água salgada do oceano, né, já começa vindo a larva do camarãozinho, vai encontrando a água salgada também aqui (dentro), aí tem toda a chance de uma boa safra. (...). Então, que nem eu te falei, tem que pegá bem escoado das águas doce e aí cumeçá a dá uns ventos de cima pra í enchendo de água salgada. (Sr. Rui, 60 anos, pescador artesanal).

$\mathrm{O}$ vento NE no início da "primavera que corre seca" sucedido pelo vento sul, depois que as águas da Lagoa já estão "baixas", são "sinais" que aumentam a possibilidade da ocorrência da safra de camarão e que marcam etapas de um processo para a entrada de "pontas de água salgada" com larvas de camarão no estuário ${ }^{182}$ ('a larva mesmo vem do oceano. Pra salgá a água, (precisa) chuvê pouco na primavera pra entrá água salgada, né') . O vento nordeste, como todo “vento de baixo", produz um

\footnotetext{
${ }^{179}$ Como foi colocado na etnocronologia estuarina, o "inverno cum muita chuva" e o "cum pouca chuva" compõem uma só categoria: o "inverno cum chuva". E, neste sentido, as consequências para a safra de camarão são semelhantes, pois ambos favorecem à formação do "ano de água misturada".

${ }^{180}$ Neste caso, o "inverno cum chuva" inclui, além do final do "inverno", o início da primavera.

${ }^{181}$ Os ventos S e o NE são apenas um representante de cada categoria de ventos, os "ventos de cima" e os "ventos de baixo", respectivamente.

${ }^{182}$ Vale ressaltar que há alguns pescadores que acreditam que o camarão não entre do oceano ('ele tira criação aqui mesmo') e os que acreditam que ocorre a entrada de camarão do oceano, mas "a maior força é daqui mesmo".
} 
regime de vazante estuarina ${ }^{183}$ "escoando" a "água doce do inverno" ("Aí dá os ventos nordeste, pega-tirando aquela água doce que chuveu no inverno e também num [...] vai chuvê na estação da primavera e aí vai baixando a lagoa aí'), enquanto, posteriormente, os "ventos de cima", provoca a entrada no estuário e no "nosso mar" de "pontas de água salgada do oceano" com as larvas de camarão ('Então, que nem eu te falei, tem que pegá bem escoado das águas doce e aí cumeçá a dá uns ventos de cima pra í enchendo de água salgada').

No entanto, a partir do "inverno" que "não chove muito", os "sinais" que compõem a "primavera" na construção da safra de camarão são os mesmos da "primavera" que decorre do "inverno cum muita chuva" (chuva, 'ventos de cima' e 'de baixo'), embora com menor importância para um dos "sinais", o vento NE, devido a menor quantidade de "água doce" no estuário.

Vale ressaltar que qualquer das subcategorias do "inverno cum (pouca ou muita) chuva", diminui as possibilidades de chuva na "primavera" favorecendo que ela se construa como contingência para a safra do camarão no verão. Além disso, a ZM permanece próxima ao "nosso mar" impedindo que o camarão migre "lá pra Lagoa". Por isso, como foi visto na etnocronologia estuarina, é clara a preferência pelo "inverno cum chuva". Já com o "inverno seco", aumenta-se as possibilidades de chuvas na "primavera", o que pode inviabilizar a safra de camarão.

Quando o "sinal" "chuvas" não ocorre no "inverno", a categoria gerada, o "inverno que corre seco", pode fundar o "verão" já em agosto:

... setembro, outubro já pegava a pescá e dava camarão. (...). Quantas vezes em época de natal fazia mareadas boas. (...). Num era todos os anos que dava (em setembro, outubro), as veiz em quando tinha um ano que dava. Eu mesmo e o Xexéu teve um ano que a gente ia pescá dia nove de agosto. Não ia todas as noites (...), mas pesquemo sempre até janeiro, até início da safra. (...). $\mathrm{O}$ ano correu todo ele cum água salgada também. (...). O inverno começô a aquecê um pouquinho, ele já começô a aparecê. (Sr. Zezinho, 60 anos, pescador-lavrador).

Quando o "inverno seco" conjuga-se também ao "calor" do início da “primavera que corre seca” (cumeçô a aquecê um pouquinho, ele já cumeçô a aparecê'), que permite a pesca do camarão a partir do mês de agosto, irrompe a categoria "verão

\footnotetext{
${ }^{183}$ Como foi visto em 4.2, ainda que os coreanos vejam este processo como "enchente", devido as convenções, eles têm ciência que a água que "enche", sob estas condições no "nosso mar", quando se considera o corpo principal estuarino, ela sai em direção ao oceano.
} 
de água salgada" e "ano de água salgada". Vale ressaltar que o "verão de água salgada" só irrompe, neste caso, a partir da confluência de dois "sinais": o "calor" e o aparecimento do camarão.

Diferente do "inverno cum chuva", o "inverno que corre seco" associado à "primavera que corre seca" favorece os pescadores que pescam "lá pra cima": "Que nem eu te digo: ele dá cedo por um lado e ruim pro outro, que a água re-salgada pra nóis aqui ele vai se criando e se mandando, entendesse (...). Pra lagoa é bom corrê o inverno todo de água salgada" (Sindo, 40 anos, pescador artesanal). Apesar de inaugurar a safra de camarão já em agosto, o "ano de água salgada" favorece os pescadores "lá da Lagoa", porque gera a migração do camarão "lá pra cima" ao longo da safra. Esta migração diminui a abundância do camarão em "nosso mar".

Se, no entanto, o “calor" incidir já no "inverno", uma sub-categoria de "inverno" pode surgir ${ }^{184}$ :

Eu achava que num ia fazê mais inverno, mas esse ano aqui no Rio Grande do Sul foi de apelá pras cuberta forte pro cara aquecê. São muitos ano que a gente num passava mais pelo inverno e por isso eu te digo: já tava dando camarão quase todo inverno e verão por causa do calor. Já tava dando camarão inverno e verão. (Guega, 54 anos, pescador artesanal).

Quando o "inverno seco" articula-se a mais um "sinal”, o "calor", que permite a pesca de camarão durante quase todo o inverno, gera a sub-categoria "invernos quentes e seco". Este é a única situação em que o "verão" não é fundado, para os pescadores especialistas na pesca do camarão, a partir da safra de camarão, mas o "calor" da "primavera" que sobrevém geralmente entre os meses de agosto e setembro.

Com o aparecimento de camarão em território coreano funda-se o "verão" e abole-se o "inverno". A partir das duas categorias de "inverno", "cum chuva" e "seca", associada às duas categorias de "primavera", segundo a experiência temporal dos coreanos somente três categorias de "verão" e "ano" são geradas:

E essa do camarão (...), se dé ano de enchente não vai dá nenhum. Se dé um ano de uma água meia misturada e tal, nóis matemo ele aqui. Agora, ano de água cortada, o pouco que tem aqui vai embora. Água cortada é água baixa, salgada. Pra guentá pra nóis aqui tem que tê uma mistura de água doce, não completamente água doce, mas uma certa mistura de água doce. Anos que

\footnotetext{
${ }^{184}$ Estas duas que se desdobram do "inverno seco" não foram descritos na etnocronologia estuarina, pois não resultam em e nem sofrem implicações da hidrodinâmica estuarina.
} 
nem foi esse aí num presta, muito cortada demais, muita água salgada. (Sr. Meca, 68 anos, pescador-lavrador).

As três categorias de "verão"185 e "ano" geradas são o "de água doce", o "de água salgada" e o "de água misturada”. Na primeira não ocorre safra de camarão ('Se dé ano de enchente não vai dá nenhum'), enquanto nas duas categorias seguintes ocorre. Porém, no "verão de água salgada" a safra de camarão é desfavorável ao "nosso mar" ('...ano de água cortada, o pouco que tem aqui vai embora. [...]. Anos que nem esse aí num presta, muito cortada demais, muita água salgada'), enquanto no "de água misturada" é favorável ('Pra guentá pra nóis aqui tem que tê uma mistura de água doce, não completamente água doce, mas uma certa mistura de água doce').

Portanto, qualquer combinação de categorias temporais é favorável à entrada de "pontas de água salgada" com larvas de camarão do oceano nas águas da Coréia, desde que o sinal "chuvas" não ocorra na "primavera" ("primavera cum muita chuva'), sobretudo a partir de outubro.

A partir da entrada de "ponta de água salgada" em território coreano, a entrada de larvas de camarão ('casquinha') ${ }^{186187}$ é contínua:

\begin{abstract}
Mas esse ano, era metendo água sempre, sempre, direto. Sempre, sempre metendo água. (...). Eu queria que tu visse, sempre metendo água, sempre metendo casquinha, sempre metendo casquinha. A água toda salgada sempre, né. Passei pelo inverno todinho, entrei quase verão, pescando peixe-rei. E sempre metendo água. E todos os ano que dá camarão é assim: meteu água salgada pra dentro, mete casquinha também. Claro, no tempo dele entra, né. (Gordo, 36 anos, pescador artesanal).
\end{abstract}

A entrada das "casquinhas" funda um tempo de espera para que o camarão atinja um tamanho considerado bom ${ }^{188}$ para o início da safra. A entrada contínua de larvas no estuário possibilita a existência de várias coortes de tamanho de camarão o que, para o "nosso mar" que é "criador do bixo", é fundamento para a existência de "falhas" durante a safra e de diferentes padrões migratórios ao mesmo tempo.

\footnotetext{
185 O "ano" a que o Sr. Meca se refere, neste caso, pode ser considerado sinônimo de "verão".

186 “A casquinha é o camarão miúdo, é o camarão mesmo, é o próprio camarão, a larvinha” (Gordo, 39 anos, pescador artesanal).

${ }^{187}$ Há um grupo de pescadores que não acreditam que a larva de camarão entre do oceano: "O camarão num sei mas... tem aquele negócio: tem gente que diz que o camarão num entra. O pai mesmo, ele briga cum o cara se o cara dissé pra ele que o camarão entra. Ah é, o pai diz que ele não entra. Eu num acredito que ele não entre. (...). E já vi muitos dizê que não, que não entra. E também vi gente dizê que ele entra, né" (Moisés, 45 anos, pescador artesanal).

${ }^{188} \mathrm{O}$ tamanho de camarão considerado bom é a partir de $9 \mathrm{~cm}$.
} 
Já que "pontas de água salgada" têm como prazo máximo de entrada no estuário o mês de dezembro ('lá pro natal'), a safra de camarão inicia-se no máximo no final de janeiro:

Camarão cria em quinze dias! Faz um solaço aí e água baixa, ele pode tá desse tamanhozinho, assim ó, dentro de quinze dias tu pode se prepará que ele já tá cum nove-dez centímetros de tamanho. Cria em dois toque! Cria, cria... (Guega, 54 anos, pescador artesanal).

Se as condições para o crescimento do camarão forem ideais, marcadas pelo "sinal" "água baixa" e "calor", o tempo necessário para que ele atinja um tamanho considerado bom é por volta de quinze dias, o que implica numa safra com início máximo ao final do mês de janeiro ${ }^{189}$.

Na Coréia, o "sinal” que funda o início da pesca do camarão é o aparecimento do camarão que "qué viajá" nas redes de "saquinho"190, que indica que uma coorte de camarão já atingiu o tamanho considerado bom:

O que manda mesmo é a correnteza, a feição da água. Tu tens que esperá a água deferente, tens que colocá a andana de frente à correnteza. E na feição o camarão que tu pega já é outro camarão deferente, né, ô, um camarão metido a vermelho. Que nem eles pescam ali, ó, de encontro à croa, na beira da croa, e trabalham na feição, entendes. Então aquele camarão o destino dele é viajá, né, o da feição. (Guega, 54 anos, pescador artesanal).

Este "sinal", o camarão que "qué viajá", "metido a vermelho", "camarão de saída", é um camarão que vai realizar sua migração no sentido sul-norte no interior do estuário, do "nosso mar" vai "lá pra cima".

Alguns "sinais", a princípio, soam como um prenúncio de boa safra de camarão: “Ano de mosquito é ano de camarão" e "Ano de araçá é ano de camarão". Na verdade, constituem referenciais em terra, imbuídos de temporalidade, que subsidiam uma avaliação das condições climáticas para a safra de camarão:

\footnotetext{
${ }^{189}$ No entanto, no período dos "represos", quando o "sinal" é o oposto, "água cheia", para os padrões de nível de água para o "verão", o camarão não atinge o mesmo padrão de tamanho que o período fundado pelo "sinal" "águas baixas": "Pra ti vê que uma coisa bate cum a outra, né: conforme a planta, o camarão. Tudo precisa do calor... pra crescê. (...). Assim é o camarão: cum água cheia, que ele gosta do barro pra crescê, croa seca. Num tendo croa seca acontece que nem esse ano que passô: ele não cria. (...). Porque esse ano passado ele nem criô, ele era um camarão sempre de um tipo só? Porque ele num tinha caloria de sol e nem água baixa que batesse o sol lá embaixo aonde ele tava que aquecesse o chão que era pra ele se criá, entendes" (Guega, 54 anos, pescador artesanal).

${ }^{190}$ A rede "saquinho" é uma rede fixa para camarão.
} 
Se corrê pro Araçá, corre pro camarão. Sabe por que que corre? Por causa que o tempo corrê pra produzí aquela fruta, então que aí num chove, né, e a fruta produz. Então é quando produz também peixe. Então eles se baseava nisso aí, os antigo tirava uma base por isso aí. Esse ano num foi muito não. Esse ano num correu pra ele não, então já vê que foi pouca a produção no mar também. É tudo quando corre pra uma planta, corre pro mar também a mema coisa, né... a monção. É o mesmo: se chuvê demais num produz nada, já não produz nem no mar nem em terra... num produz nada. (Dino, 67 anos, pescador artesanal).

Como o camarão, o Araçá 191 e o "mosquito"192 surgem ao mesmo tempo, as condições climáticas avaliadas que "não produz nem no mar nem em terra" são as da "primavera", sobretudo as chuvas.

Se o início da safra do camarão é muito variável ainda que dentro de um intervalo de tempo, entre agosto e janeiro, dependendo das migrações das larvas de camarão do oceano para o estuário, o seu fim é caracterizado por um tempo mais cadenciado, embora tenha alguma flexibilidade, e pela migração reprodutiva em massa do camarão em sentido contrário, do estuário para o oceano, a "arriada do camarão"193.

Só vai saí de lá quando esfriá o tempo em abril-maio. Quando dé a corrida pra tainha como a gente chama. Que a tainha se mexe pra saí lá, pra í embora pro oceano, né. Ela vai se mexê lá na minguante de abril e minguante de maio. (...). Dá-le saragasso de vento rebojo, aí sim, ela se movimenta de lá pra saí. O frio acha ela e ela vem embora. Quando ela se mexe lá, o camarão se mexe pra vim embora também. Aí sim ele vem embora ligeiro. (Sr. Meca, 68 anos, pescador-lavrador).

O "fim de safra" é marcado pelo "camarão de arriada" que só ocorre, dentro do cenário de "verão de água salgada" e "de água misturada", mediante confluência de quatro "sinais de memória": o vento rebojo ('Dá-le saragasso de vento rebojo, [...], aí ela se movimenta de lá'), o frio ${ }^{194}$ ('O frio acha ela e ela vem embora'), “a corrida da tainha” ('Quando ela se mexe lá, o camarão se mexe pra vim embora também') e a Lua minguante nos meses de abril e maio ('Ela vai se mexê de lá na minguante de abril e minguante de maio'). A “corrida da tainha” também constitui um "sinal” para o fim de safra do camarão, porque as duas pescas ocorrem quase ao mesmo tempo, mas a tainha

\footnotetext{
${ }^{191}$ O “araçá" é o fruto do Psidium littorale (SAMPAIO, 1987).

192 Culex sp.

193 O “camarão de arriada", em parte, é o camarão que saiu do "nosso mar" e foi "lá pra Lagoa" e retorna "de arriada" no "final da safra".

${ }^{194}$ Em geral, nas entrevistas, são citados apenas três sinais (vento rebojo, Lua minguante e os meses de abril e maio) para a ocorrência do "camarão de arriada" e da "tainha de corrida". O "frio" frequentemente não é citado como um "sinal". Isto se deve ao vento "rebojo" ser considerado neste período do "ano" um vento frio, e que esfria cada vez mais e, por isso, o vento "rebojo" e o "frio" podem ser considerados um só "sinal".
} 
primeiro durante o vento "rebojo" e o camarão em seguida, na calma do vento "rebojo", como será visto adiante em 4.4.2.

Como o vento "rebojo" dura interruptamente por volta de 3 a 4 dias e a pesca da tainha ocorre quase ao mesmo tempo, a "arriada do camarão" torna-se um evento intenso e frenético ${ }^{195}$. A marcação do tempo através de materializações no espaço ('sinais de memória') faz do tempo da "arriada do camarão" um evento, antes de biológico, social que confere certa previsibilidade à dinâmica ambiental.

Há, no entanto, dois "sinais" que indicam uma antecipação e dois que indicam protelamento do "fim de safra" do camarão. Um que antecipa é "trovejá" e "chuvê muito" na direção de Pelotas e de "Porto Alegre": "A gente quando pescava, eu pescava, a gente quando via trovejá, chuvê, muito ali em Pelotas, Porto Alegre, dizia assim ó: 'Foi-se a safra de camarão'. A gente já esperava que num dura nada, terminava" (Sr. Dino, 67 anos, pescador artesanal). O "troveja" e "chuvê muito" são "sinais de memória" que prenunciam o "fim de safra" do camarão, devido às intensas correntes de "enchente" 196 resultantes da descarga fluvial:

\begin{abstract}
Agora quando a água é doce e tem força de água pra cima ela entra aqui, ela entra aqui (nas Boca) e sai lá (na outra costa) e vai embora. (...). Ela entra aqui ó, ela limpa tudo aqui ó. O peixe que tem pra aqui ela vai limpando, limpando e essa água entra aqui, ela já sai barra fora. Então ela vai levando todo o peixe que tem como o camarão: o camarão, se tivé bastante camarão, e chuveu pra Pelotas, pra Porto Alegre, dá um nordeste, e a água cumeça a entrá aqui só correndo a volta, fazendo a volta, tremina o camarão todinho, todinho. (Sr. Dino, 67 anos, pescador artesanal).
\end{abstract}

Os regimes de "enchente" gerados pelas chuvas "lá pra cima" (“...tem força de água pra cima ela entra aqui [...] e sai lá e vai embora'), sobretudo quando associados ao vento nordeste ('dá um nordeste'), “leva” o camarão de todo o estuário ('Então ela vai levando todo o peixe que tem como o camarão'), inclusive do "nosso mar", para o oceano ('sai barra afora').

Outro "sinal de memória" que indica a antecipação do "fim de safra" de camarão no "nosso mar" é o "noroeste cum chuva" durante a safra:

\footnotetext{
195 Devido à intensidade deste período de pesca, muitos pescadores optam por realizar apenas uma das pescarias e, frequentemente, o recurso escolhido é o camarão.

${ }^{196}$ Vale lembrar que os intensos regimes de vazante de água doce para os coreanos ganha significado de regimes de "enchente", devido às suas próprias convenções, como visto em 4.2.
} 
Qué vê dando noroestão em plena meia safra de camarão e cum chuva. Já aconteceu de safra terminá. Da noite pro dia terminá. (...). Uns oito ano, por aí, (...), rapaz, mas tinha camarão! (...). E deu-le aquele noroestão, (...). Rapaz, deu-le dois dia de noroestão... cum chuva, limpô tudo, num ficô nada! (...). Adoçô tudinho, cara, de um dia pro outro treminô! Deu mai nada! Entrei inverno adentro e num deu mai nada. (Gordo, 39 anos, pescador artesanal).

O vento noroeste intenso ('noroestão') e duradouro ('dois dia') "cum chuva" é "sinal" de "fim de safra" de camarão em todo o estuário inaugurando o "inverno" ("Qué vê dando noroestão em plena meia safra de camarão e cum chuva. [...]. Adoço tudinho, cara, de um dia pro outro treminô! Deu mai nada! Entrei inverno adentro e num deu mai nada').

Por outro lado, apenas o vento noroeste, dissociado das chuvas, durante a safra de camarão ganha um outro significado, uma safra "ruim" apenas no "nosso mar":

\begin{abstract}
Mas o noroeste nunca, nunca foi bom. É o mesmo que a safra de camarão: quando no camarão no início dá muito desse vento aí num presta. É porque ele vai criando e vai embora pra cima, ele vai criando ele num pára aqui dentro, vai criando e vai-se embora. Já vai pequeno mesmo vai embora, (...). Pra nóis aqui num presta. (Sr. Dino, 67 anos, pescador artesanal).
\end{abstract}

O vento noroeste, como foi visto em 4.2, provoca intensos regimes de vazante em "nosso mar" favorecendo a saída do camarão precocemente do "nosso mar" ('quando no camarão no início dá muito desse vento aí num presta. [...], ele vai criando ele num pára aqui dentro'), mas não do estuário da Lagoa dos Patos ('É que ele vai criando e vai embora pra cima'). O significado atribuído ao vento noroeste, neste caso, é equivalente ao do "verão de água salgada" ou "ano de água salgada" em que há uma migração intensa de camarão do Saco do Arraial “lá pra cima, lá pra lagoa”. Isso implica, para muitos pescadores, como foi observado em campo, no abandono da safra de camarão em favor de outra safra, como a tainha.

Atrelado ao verão de "água salgada" ou "misturada", um dos "sinais" que fundam o prolongamento do fim da "safra de camarão", diferente da antecipação da safra, "tem tempo certo" de acontecer:

Vai do tempo que calha que cai o minguante, né: se cai no início de mês no caso aí já pode até pegá o outro e dá em junho ainda, né. Sendo bom o início de junho. No caso vai tá em maio ainda, né. Pega início de maio com minguante ele vai dá outro em junho né, em início de junho. Ainda é tempo de dá algum peixe. (...). A tainha e o camarão, o camarão também. (Moisés, 45 anos, pescador artesanal). 
Se a Lua minguante ocorrer no início do mês de maio há a possibilidade de acontecer uma terceira "arriada de camarão" ('Pega início de maio com minguante ele vai dá outro em junho'), a minguante de junho ('Sendo bom o início de junho'), adiando em um mês o fim da "safra de camarão".

O outro "sinal" que possibilita uma safra de camarão mais longa é o "lixocapim":

Todo o ano cara, (...), ano pra nóis aqui que tem lixo-capim tem safra de camarão. Não tem lixo-capim, não tem safra de camarão. (...) .Teve um ano aqui que pra í pra andana ${ }^{197}$ nóis tivemo que pará o motor cinco-seis veiz pra chegá na andana. Mas fora d'água, tava grandão. E foi uma safra de camarão até tarde sabes. (...). Aquele ano foi a junho dentro. (...). Bem tardão! (...). Isso é sagrado, segura mais o camarão memo. (Moisés, 45 anos, pescador artesanal).

Ano de lixo-capim aguenta camarão até tarde. Ah, o camarão se solta, né, só sai do meio dele depois de criado memo, depois de grande. (...). Basta que quando num tem lixo-capim o camarão num tem paradeiro aqui, nem o camarão nem nenhum outro peixe. (Guega, 54 anos, pescador artesanal).

Segundo os pescadores, "ano de lixo-capim aguenta camarão até tarde", ou seja, “ele não vai todo lá pra cima”, prolongando a safra de camarão até o início de junho ('Aquele ano foi junho adentro').

Além do prolongamento da safra de camarão, é interessante notar que, o "lixocapim", articula-se ao "verão" e ao "ano" considerado o melhor e, por isso, o mais esperado para a pesca do camarão:

\begin{abstract}
Esse aí qué uma água mais misturada, acho que ele gosta mais. Corrê um ano que nem esse daí cum água salgada é difícil achá um lixo-capim aí. Acha, né, um lixinho dessa alturinha, mas tem anos que o lixo-capim sai fora d'água. É até bonito de vê: dá essas calmaria. Eu acho que é anos que a água salga e adoça e tá sempre misturada aquela água, sabes. Eu acho que ele gosta mais que é o ano que o cara vê mais lixo. (Evaldo, 36 anos, pescador artesanal).
\end{abstract}

A maior abundância de "lixo-capim" é observada pelos pescadores sob as condições hidrodinâmicas do "verão de água misturada" ou "ano de água misturada" ('Esse aí qué uma água mais misturada [...]. Eu acho que é anos que a água salga e adoça e tá sempre aquela água mistutrada').

A presença de "lixo-capim" no "nosso mar" sinaliza outras consequências para a safra do camarão, como o aumento da abundância ('Por causa do lixo capim. Mai deu

197 “andana" são os pesqueiros de propriedade individual registrados no IBAMA para a pesca de camarão. Sobre as andanas ver 4.4.2. 
camarão! Todo esse mar aí, era sagrado, todo mundo matava camarão. Isso é sagrado, segura mais o camarão memo' Moisés, 45 anos, pescador artesanal) e do tamanho ('Ah, o camarão se solta, né, só sai do meio dele depois de criado memo, depois de grande. (...). A gente num sabe, né, mas aonde tem lixo-capim cria peixe enorme' Guega, 54 anos, pescador artesanal). Por tudo isso (aumento dos prazos, tamanho e abundância), o "ano de lixo-capim" é tido como um "tempo bom pra camarão" em "nosso mar", um "tempo de fartura".

Como a maior parte dos pescadores da Coréia se especializou na pesca do camarão, o seu aparecimento é o "sinal" que traz a derrocada do "inverno" que vem sendo descontruído desde a "primavera" com o aparecimento de sucessivos "sinais" que gradativamente vão construindo o "verão" (vento nordeste, 'calor', 'pontas de água salgada', 'águas baixas', larvas de camarão, etc). Por outro lado, o término da safra de camarão abole o "verão" que também é desconstruído ao mesmo tempo em que se constrói o inverno ('rebojo frio', 'tainha de corrida', 'camarão de arriada', 'águas cheias', 'pontas de água doce', etc).

\title{
4.4.1.1.2. A tainha
}

A tainha, assim como o siri, "dá sempre, inverno e verão"198. Por isso, a construção do tempo da tainha será feita em dois momentos. Neste primeiro momento, serão estabelecidos os "prazos" para a tainha que é pescada durante o "verão" e, posteriormente, para a tainha que é pescada no "inverno" segundo as suas diferenças em relação a esta primeira.

Para a pesca da tainha no "verão", os "sinais" que prenunciam uma "safra ruim" ou "boa", desenrolam-se a partir da ocorrência ou não de chuvas na "primavera" da mesma forma que foi analisado para o camarão em 4.4.1.1.1:

\begin{abstract}
A tainha é o mesmo que o camarão, basta que tem camarão a reveria e tem tainha. Saiu a tainha... o camarão sai atrás dela, vai todo pra cima. Então, pra mim, é o mesmo estilo da tainha, é o mesmo estilo do camarão. Basta, tu vê só, quando é ano de lixo ${ }^{199}$ é ano de camarão, né. Ano de tainha também é, porque a tainha tá marcando igual também. Eu acompanho a tainha cum o mesmo que o camarão. Pra mim a mesma coisa é. Dá na mesma época, é tudo
\end{abstract}

\footnotetext{
${ }^{198}$ A “tainha de verão" é correlacionada com água salgada, enquanto a "de inverno" com água doce.

199 Até o lixo-capim é um "sinal" partilhado entre camarão e tainha para o prenúncio de "boa safra".
} 
na mesma época. (...). Por isso que eu digo: onde dá tainha, dá camarão. Pra mim, correu bom pra camarão, bom pra tainha também. (Gordo, 39 anos, pescador artesanal).

Neste sentido, os "sinais" que marcam a entrada de "tainha do oceano" e a construção de um tempo de contingência para a sua pesca são os mesmos que os para o camarão: "Outubro, setembro, cum vento sul, é muita tainha que entra, quando a água é salgada, e vai embora pra lagoa...” (Sindo, 40 anos, pescador artesanal). A associação entre os "sinais" "primavera que corre seca", "ventos de cima" e, consequentemente, "pontas de água salgada" são considerados eventos imprescindíveis para a entrada de "tainha do oceano".

No entanto, a confluência destes três sinais ('primavera que corre seca', 'ventos de cima' e 'pontas de água salgada') gera apenas a contingência para a safra da tainha de verão:

Tinha que salgar também, se não tivesse água salgada também, não dava (...). Quando dá ponta de água salgada o peixe vem... é que nem a tainha, dava o nordeste ela arreia. Quando dá a água salgada ela vem pra cima, a gente tentiava, dava o nordeste e ela vinha, aí a gente pegava ela. Quando a água doce vinha a gente pegava ela na ponta d'água. (...). Tinha que dar uma misturada, só água salgada não dava. (...). Se a água ficar toldada não dá também. (Sr. Dino, 67 anos, pescador artesanal).

Diferentemente que a safra de camarão, para que se inaugure a safra de tainha no "nosso mar" e o "verão", para os especialistas na pesca de tainha, é necessário que à contingência se articule mais dois "sinais" para o irrompimento da safra ("Tinha que salgar também [...]. Quando dá a água salgada ela vem pra cima, a gente tentiava...'): a chegada do vento nordeste e das "pontas de água doce" ('Dava o nordeste e ela vinha, [...]. Quando a água doce vinha a gente pegava ela na ponta d'água'). Consequentemente, com a chegada de "pontas de água salgada", "de água doce"200 e das tainhas, durante a "primavera que corre seca" inaugura-se o "verão de água misturada" em território coreano ('Tinha que dar uma misturada, só água salgada não dava. [...]. Se a água ficar toldada [doce] não dá também'). Neste caso, em que se inaugura um novo ritmo para a safra de tainha e o "verão" no "nosso mar", ainda que durante os meses que seriam da "primavera": "Junta a primavera cum o verão só que no

\footnotetext{
200 As "pontas de água doce", como foi visto, é resultado de chuvas que aumentam as descargas fluviais para a Lagoa dos Patos. Porém, é desejada a chegada de "pontas de água doce" que dê "uma misturada" na água e, neste caso, para os coreanos, a "primavera" continua sendo classificada como "que corre seca".
} 
verão aí é melhor. É, a tendência é aumentá, melhora mais a pesca” (Sr. Rui, 60 anos, pescador artesanal).

A ocorrência de "só água salgada" durante a "primavera" ("primavera que corre seca resultante de um 'inverno seco') ou de "água toldada (doce)" ('primavera cum muita chuva') impede que se inaugure no "nosso mar" a safra de tainha de verão a partir da contingência gerada pela entrada no estuário de "tainha do oceano" articuladas às "pontas de água doce" e ao vento nordeste entre setembro e dezembro: "Aí depende, tens que vê pela água, conforme a água: se a água é doce demais, a pouca tainha que tem nesse mar nosso aqui vai pela barra e a que qué entra num entra. Mas quando ela é salgada, ela só enche e a tainha vai embora direto pra Lagoa" (Sindo, 40 anos, pescador artesanal). Neste sentido, durante a "primavera", "se a água é doce demais" ("primavera cum muita chuva') os "ventos de cima" não conseguem forçar a "entrada de água salgada" com tainha no estuário e retira para o oceano boa parte da tainha então existente no estuário; "quando ela é salgada" ('primavera que corre seca' resultante de um 'inverno seco') a tainha migra "direto pra Lagoa" não entrando em território coreano. Portanto, só o "ano de água misturada" perfaz o conjunto e a sequência de "sinais de memória" necessários para que uma safra de tainha considerada "boa" seja inaugurada em território coreano a partir do mês de setembro.

Para qualquer um dos outros dois cenários de "anos", "de água doce” ou "de água salgada", em que a tainha não entra em território coreano com os ventos nordeste e "pontas de água doce", o "sinal" que inaugura a pesca de "verão" de tainha é o mesmo: "É mais pro verão, é mais fím de setembro-outubro cumeça a esquentá, cumeça a aparecê tainha mais bonita. (...), muita que tem aí agora no inverno é miudeira, (...), já cria também, né, cum o tempo mais quente, cria ligeiro e já cumeça a aparecê peixe junto" (Evaldo, 39 anos, pescador artesanal). O aumento da abundância e de tamanho da tainha a partir do "calor" de setembro inaugura o "verão", "de água doce" ou "salgada", para os pescadores especialistas na pesca da tainha.

Também os "prazos" estabelecidos para a "entrada de tainha do oceano" são os mesmos que o do camarão: “Tem essas tainha miúda aí, de água doce, agora no inverno. Elas vão se criá cum a tainha que vai entrá do oceano agora, de setembro em diante, pra dá a de coresma no verão, do Natal em diante, e adepois a corrida" (Dino, 67 anos, pescador artesanal). Os "prazos" de entrada de tainha também são os mesmos que o camarão: de setembro a dezembro ('...a tainha que vai entrá do oceano agora, de 
setembro em diante, pra dá a de coresma no verão, do Natal em diante...'). No entanto, a frustração de uma "boa safra de tainha" pela ocorrência de "primavera cum muita chuva", que impedem a entrada de "tainha do oceano" entre setembro e dezembro, não significa como no camarão, a inexistência da safra ('tem essas tainha miúda aí, de água doce, agora no inverno'), pois já existe tainha pescada no "nosso mar" durante o inverno ('tainha de água doce') ${ }^{201}$.

De qualquer forma, o "Natal", assim como no camarão, é a data limite para que ocorram as "entradas de peixe do oceano" e, a partir daí, "do Natal em diante", no "verão de água salgada" ou "de água misturada", se inicie a pesca da tainha de "verão", chamada de "tainha de coresma"202. "A coresma é um peixe criado aí no lameirão (...) não é peixe criado prá í embora lá pra lagoa. (...). Ela dá do Natal até o início do inverno... até vim a corrida" (Dino, 67 anos, pescador artesanal). O "Natal", portanto, também marca o início da atividade pesqueira da "tainha de coresma" ${ }^{203}$. Neste sentido, é a "tainha de coresma" que funda o "verão de água salgada" e o "ano de água salgada" após o "natal" para os especialistas na pesca da tainha.

Ao contrário da "tainha de coresma" que se pesca "aqui pra dentro", um "peixe de lameirão", no "fim de safra" busca-se "ali fora" a tainha que viaja "a canal", durante sua migração reprodutiva do estuário para o oceano, a "tainha de corrida":

A tainha de corrida é um peixe que pega canal à baixo. Ela se junta e diz assim: 'Vamo embora pro oceano' e vai canal a baixo. A corrida, a verdadeira. (...) a grande de corrida que veio de arriada, que nem a gente diz tainha de corrida, que arriô, veio de cima, lá da Lagoa pro oceano. (Rui, 60 anos, pescador artesanal).

Enquanto o início de safra ocorre pela migração da tainha para o estuário ('entrada de tainha do oceano') e para o "nosso mar", o "fim de safra", ao contrário, é marcado pela migração reprodutiva da tainha "da Lagoa pro oceano" ("A tainha de corrida é um peixe que pega canal a baixo. [...] a grande de corrida que veio de arriada [...], veio de cima, lá da Lagoa pro oceano').

\footnotetext{
${ }^{201}$ A "tainha de água doce", etnoespécie que fica no "nosso mar" durante o "inverno": "A tainha de água doce ela cria aí mesmo, no inverno" (Amarildo, 40 anos, pescador artesanal), também corresponde a espécie Mugil platanus.

${ }^{202}$ O que os pescadores chamam de "tainha de coresma", é, segundo a taxonomia científica, a espécie Mugil curema e Mugil gaimardianus. Já a "tainha de corrida” é Mugil platanus. Seixas e Berkes (2003) registraram a etnoespécie "Parati de coresma" entre os pescadores da Lagoa de Ibiraquera (SC).

${ }^{203}$ Alguns pescadores consideram a entrada desta tainha em território coreano com o vento nordeste o início da safra de "tainha de coresma".
} 
A "corrida da tainha" é fundada a partir da confluência de diversos "sinais de memória": "Tem o minguante de abril, maio e junho. Pra mim o milhór é o primeiro rebojo, cara. Ah, é, o minguante de abril. Parece que a tainha vem mais junta, cara" (Sindo, 40 anos, pescador artesanal). Assim como o camarão, o vento "rebojo", o "frio" e a Lua minguante nos meses de abril e maio são os quatro "sinais de memória" que devem ocorrer ao mesmo tempo para que se inaugure a pesca da "tainha de corrida" e o fim de safra da tainha. Como o vento "rebojo" dura interruptamente por volta de 3 a 4 dias, a "corrida da tainha" torna-se um evento intenso e frenético, pois a sua ocorrência se interpola em dois momentos pontuais da safra da tainha. Cessada a confluência de "sinais", abole-se a "tainha de corrida" e, no caso da "tainha de corrida" do mês de maio, o "ano de água salgada" ou "de água misturada" reiniciando um "ano".

Há, no entanto, como no camarão, um "sinal” que indica uma antecipação e dois outros que indicam um prorrogamento do "fim de safra de tainha". O que antecipa é, como no camarão, "chuvê muito" e a consequente chegada de "pontas de água doce": “Ah, se chuvê muito pode vim antes das minguante, a água doce empurra a tainha, né. (...), aí arreia cum tudo" (Delso, 40 anos, pescador artesanal). As chuvas durante o "verão", segundo os coreanos, não tem data certa para acontecer e, por isso, o monitoramento da previsão do tempo nas rádios e na TV é constante junto às chegadas de "ponta de água doce".

Um sinal que indica o prorrogamento da safra de tainha é o "lixo-capim":

\footnotetext{
Aonde pegá um moiteira de lixo-capim... eu num sei se ele cria alguma coisa no meio dele que o peixe gosta de cumê. (...). Tu mexia no lixo-capim a remo, tu até se assustava do tamanho das tainha que ressulhava. (Guega, 54 anos, pescador artesanal).

O lixo-capim é bom pra qualqué peixe, no caso, porque segura, né. O peixe fica ali no meio e num sai, né. Até a tainha, vai junho adentro (...). $\mathrm{O}$ ano que tem lixo tem fartura. (Moisés, 45 anos, pescador artesanal).
}

Em "anos" que têm "lixo-capim" ('ano de água misturada'), assim como o camarão, é possível se pescar tainha considerada de tamanho "bom" ("Tu mexia no lixocapim a remo, tu até se assustava do tamanho das tainha que ressulhava') até o início do mês de junho ('O peixe fica ali no meio não sai, né. Até a tainha, vai junho adentro'), ou seja, após a "tainha de corrida". 
O outro "sinal" de adiamento do fim da safra da tainha é a Lua minguante de junho:

\begin{abstract}
Vai do tempo que calha que cai o minguante, né: se caí no início de mês, no caso, aí já pode até pegá o outro e dá em junho ainda, né. Sendo bom o início de junho. No caso vai tá em maio ainda, né. Pega início de maio com minguante ele vai dá outro em junho, né, em início de junho. Ainda é tempo de dá algum peixe. (...). Um sarralhinho depois até dá, né, mas é pouquinho peixe. Foi a última que ficô lá, perdida. Aí ela vem. (Moisés, 45 anos, pescador artesanal).
\end{abstract}

Se a Lua minguante ocorrer no início do mês de maio, há a possibilidade ('Sendo bom o início de junho') de acontecer uma terceira corrida da tainha, a minguante de junho, adiando em um mês o fim da safra de tainha ('se caí no início do mês, [...], aí já pode até pegá o outro que dá em junho ainda, [...]. Foi a última que ficou lá, perdida. Aí ela vem'). Ao fim da confluência de sinais, sobretudo do vento rebojo, abole-se a safra de "tainha de verão". Abolida a confluência de "sinais" para a corrida da tainha, sepulta-se também o "ano", reinicando um outro "ano".

Com o "fim de safra" da "tainha de corrida", também termina a safra da "tainha de coresma":

Essa tainha tem uma experiência, é engraçada, quando a tainha de corrida tá na lagoa, então quando essa coresma, que a gente trata, então quando vai dar o rebojo, que a corrida vai vim de lá, ela vai toda pra fora esperá a corrida pra ir junto com a corrida. Aí fica limpo, aí fica limpo e de primeiro ficava uma tainhotinha assim, pequeninha, e aquela outra ia tudo embora. Findava, findava a pesca de tainha. Findava a corrida, findava a pesca de tainha. Aí só vinha em agosto de novo. (Dino, 67 anos, pescador artesanal).

Segundo o conhecimento ecológico tradicional, todas as tainhas fariam a migração reprodutiva juntas, "uma busca a outra", a "de corrida busca" a "de coresma", sinalizando o fim da pesca da tainha e o início de um outro tempo, um tempo de espera. O tempo de espera, por sua vez, seria abolido a partir do mês de agosto do mesmo ano.

A abolição da pesca da tainha carrega consigo a fundação de um tempo de espera para a pesca da própria tainha que será visto no item "tainha de inverno".

Se, no entanto, o contexto for de "ano de água doce", não há safra da "tainha de coresma" e de "tainha de corrida" e a construção da safra de tainha e do próprio "verão" se esvazia, mantendo apenas um que funda e outro que abole: 
Em noventa e oito chuveu o inverno todo e o verão todo. Em noventa e oito entrô o verão aí que aqui mesmo a tua bota num apeiava. (...). E ficô assim inverno todo e verão todo. Algum siri no arroio nóis pesquemo: siri, alguma tainhota, traíra, nóis pesquemo. Aí sim, aí findô-se tudo, nem siri dava mais. Daí esfrio, né, quando terminô a época do verão, chuvia muito, mas fazia quente, né, era verão aí deu siri, aí depois esfrio, no inverno esfriô num deu mais nada. (Amarildo, 40 anos, pescador artesanal).

O "verão de água doce" e, consequentemente, a pesca da "tainha de verão" são fundados pelo "calor", enquanto o "frio" é o marco de seu término e início do "inverno" e das pescarias de "inverno". O "calor", em geral, se inicia entre agosto e setembro, enquanto o "frio" entre maio e junho.

Para alguns pescadores que são especialistas na pesca da tainha, no "verão de água salgada" e "de água misturada", o início da safra da "tainha de coresma" e o fim da "tainha de corrida" marcam o início e o fim dos ritmos de verão, respectivamente. Já no "verão de água doce", o "frio" e o "calor" ganham status de eventos que individualizam o "tempo disso ou daquilo", neste caso o "inverno" e o "verão", respectivamente.

Para a construção do calendário de pesca na Coréia, o ciclo de pesca da tainha dentro do estuário fundamenta marcos etnocronológicos com dois momentos principais em cada um dos "anos" ou "verão": a ocorrência da "tainha de corrida", no "verão de água salgada" e "de água misturada", a partir da confluência de "sinais" vento "rebojo", "frio" e Lua minguante de maio, que se reflete na abolição do "verão" ou do "ano" e a fundação de um tempo de espera pelo irrompimento da próxima safra de "verão"; a partir do "inverno que corre seco" sucedido pela "primavera que corre seca", a chegada de "pontas de água salgada" com tainha forçadas pelos "ventos de cima", entre setembro e dezembro, inaugura a contingência para a fundação da pesca de tainha dentro do território coreano com as "pontas de água doce" e ventos nordeste e do "ano de água misturada". Se a "primavera que corre seca" é antecedida por um "inverno que corre seco", a pesca da tainha de verão ('tainha de coresma') só será fundada depois do "Natal", entre dezembro e janeiro. Se o "ano é de água doce", o "calor" entre o final de agosto e início de setembro marca o início da pesca da tainha de verão e o irrompimento do "verão de água doce" ou "ano de água doce". No "verão de água doce", como não há "tainha de corrida", o marco para o início da pesca de "tainha de inverno" é o "frio" a partir do mês de maio. 


\subsubsection{As safras de inverno}

No “inverno", apenas dois recursos pesqueiros são característicos desta estação: linguado e peixe-rei, embora também sejam pescados tainha e siri, porém em menores quantidades do que no "verão". O linguado e o peixe-rei não são pescados em quantidades comparáveis aos recursos pesqueiros do "verão", mas alcançam importância de complemento de renda às "safras de verão", sobretudo ao "verão de água salgada" e ao "de água doce" que, como foi visto nas safras de verão, têm menor abundância de pescado que no "de água misturada". Por outro lado, também há categorias de "inverno" em que as condições ambientais não favorecem a pesca de peixe-rei.

Entre as duas pescas típicas de inverno, o linguado melhor representa a dinâmica da pesca de "inverno" "aqui dentro" e possui uma maior diversidade de técnicas de pesca (fixa e móvel) do que o peixe-rei. Por isso, a pesca de linguado é tomada como representante da "safra de inverno".

Diferente do verão, os "sinais de memória" que "estabelecem prazos" para as safras no "inverno" estão materializados, sobretudo, na temperatura do ar. A chegada do "frio" entre os meses de maio e junho indica o início das "safras de inverno" e a chegada do "calor" entre os meses de agosto e setembro, seu fim. Porém, a temperatura do ar é resultado da mudança de predominância dos ventos nordeste para o "rebojo", no início, e do "rebojo" para o nordeste, no fim das safras.

A apropriação da temperatura do ar como "sinais de memória" se dá porque estabelece marcos precisos para os recursos pescados somente no "inverno", um intervalo regular onde cada um destes pescados pode ser encontrado no melhor tamanho e abundância, dentro do ciclo anual, para a pesca. Por isso, apesar de os recursos pescados no "inverno" também serem encontrados durante todo o "ano" no estuário, no "verão" eles não estão em tamanho "bom" para a pesca.

Os recursos pescados durante o "ano todo", como a tainha e o siri, constituem exceção quanto à materialização do tempo em "corpos materiais" para marcar o início e o fim da sua safra, como pôde ser visto no item 4.4.1.1. Diferente das "safras de inverno" que se inauguram e se abolem com o "frio" e o "calor", os recursos que se pescam o "ano todo", como o siri e a tainha, têm sua "safra de inverno" inaugurada pela 
desconstrução da sua "safra de verão", enquanto a abolição da "safra de inverno" se dá pelo irrompimento da sua "safra de verão".

Todos os "peixes" que ocorrem durante o "inverno" podem ser pescados em qualquer uma de suas categorias ('cum chuva' ou 'que corre seco'). A única exceção é o peixe-rei que só ocorre quando é "inverno que corre seco" ou "cum pouca chuva". Neste sentido, as categorias de "inverno" são mais do que simples temporalidade da hidrodinâmica construída do estuário, mas contém um significado biológico sobre a ocorrência ou não de determinada safra.

Marques (1991) e Souto (2004) também encontraram de acordo com o conhecimento tradicional dos pescadores pesquisados a existência de "safras de inverno" e de "ano todo". Marques (1991) registrou, segundo os pescadores de Alagoas, a ocorrência do "Bagre guriaçu" (Sciadeichthys luniscutis) somente no "inverno", devido às baixas salinidades das águas estuarinas. Já em Souto (2004), os pescadores da Bahia percebem uma diminuição da abundância dos siris do gênero Callinectes no "inverno" em decorrência da diminuição da temperatura, mas também o pescam durante o "ano todo".

As "safras de inverno" não são contextualizadas em "ano de...", pois são os "invernos" o ponto a partir do qual se dá a construção dos "ano de..." e a "primavera" o momento crítico em que o irrompimento de eventos, chuvas ou não-chuva, individualizam os "anos de...".

A seguir serão construídas as possibilidades e os "prazos" para as "safras de inverno", representada pela pesca do linguado, e para a pesca de "inverno" das safras que "dá o ano todo", representadas pela "tainha de inverno.

\subsubsection{1.}

Os "prazos" para a safra de tainha já foram estabelecidos no item 4.4.1.1.2. Além dos prazos estabelecidos, ainda são necessárias algumas considerações para a construção da safra de "tainha de inverno" ou "de água doce".

A primeira delas é que, com a chegada do "frio" do mês de maio, tendo ou não saída da "tainha de corrida" e da "de coresma" em função das três categorias de 
"verão", o tempo de espera inaugurado resulta da presença de "uma tainha miúda" que não deve ser pescada antes de "criá":

Esses peixe que pescam no inverno a gente num trata de coresma, não. Ah, não, não! (...). É um peixe que tá aí de passada também, né, é um peixe que tá sempre querendo viajá pra cima, pra í embora pra Lagoa. (...). Que nem agora (no inverno): tem um rapaz que tá matando (...). Esses peixinho que ele tá matando é o tal peixe esse que tá aí pra subi lá em cima pra ficá grande. Então tão matando ela pequeninha, ela num vai vim mais, pois vão matá ela, né. Mas era o peixe que ia lá em cima e vim grande, né. (Rui, 60 anos, pescador artesanal).

O tempo de espera é para que o peixe tenha condições de cumprir seu curso migratório e desenvolvimento: “í lá pra cima, lá pra Lagoa”, “ficá grande” e depois retornar para o "nosso mar" ('vim grande') durante a "tainha de corrida" e/ou com a chegada de "pontas de água doce"204.

No entanto, atualmente este período de espera não tem sido respeitado havendo alguns poucos pescadores da Coréia ${ }^{205}$ que pescam com "malha de peixe miúdo" (30 e $35 \mathrm{~mm}$ ). Portanto, tem-se dois tempos inaugurados com o frio que inaugura o "inverno": a espera de alguns e a pesca da "tainha de inverno" por outros ${ }^{206}$.

O segundo é que a "tainha dá na água doce também", podendo ser pescada em qualquer uma das duas categorias: "inverno que corre seco" ('cum água salgada') e "inverno cum chuva" ("inverno de água doce'). Porém, em "invernos cum muita chuva" há uma diminuição ainda maior das "tainhotas" do que normalmente ocorre com a chegada do "frio":

No El Niño chuveu muito: a água se veio lá de cima, de Porto Alegre, chuveu muito naquele ano. (...). Imendô o outro inverno também cum água doce e alta. (...) siri, alguma tainhota, traíra, nóis pesquemo. (...). Daí esfrio, né, quando terminô a época do verão, (...), no inverno esfriô num deu mais nada. (Amarildo, 40 anos, pescador artesanal).

\footnotetext{
${ }^{204}$ Segundo o conhecimento ecológico tradicional dos coreanos, a tendência dos "peixes" é procurar, à medida que crescem, um "mar" cada vez maior: "Pois é, é coisa da natureza. Acho que é um mar grande, fundo e muito grande e ela vai se criá lá, né. Num sei se tem mais como ela cumê lá, né, porque aí os mares pequenos num vai tê condições de alimentá ela. (...). E lá é muito grande, né, então quando ela fíca grande que ela acha que aquele mar ali também já tá ficando pequeno pra ela, ela qué í prum mar maior, né. (...). Então ela vem pro oceano, né. (...). Ela fica um peixe grande, ela qué procurar um mar maior talvez pra alimentação dela mesma, né" (Sr. Rui, 60 anos, pescador artesanal).

205 A maior diferença e conflito, no entanto, se dá entre os coreanos e os da vila. Estes úlitmos comparecem em muito maior número num tempo em que se considera de espera na atividade pesqueira e não de ação.

${ }^{206}$ A "tainhotinha" que se pesca no "inverno" também existe durante o verão junto com a "tainha de coresma”, mas ela não é pescada sob efeito da utilização da malha 40-45mm.
} 
Neste sentido, com a inauguração do "inverno cum muita chuva" há a escassez de pescado em "nosso mar" que só é abolido com o irrompimento de um "verão".

A pesca da "tainha de inverno" se constrói e descontrói em função da abolição e do irrompimento da pesca da "tainha de verão", seja qual for a categoria de tempo em que se contextualiza a transição de uma safra para outra. A abundância da "tainha de inverno" sempre será menor do que a da "tainha de verão", em qualquer uma das possibilidades construídas pela experiência temporal dos coreanos.

\subsection{O linguado}

A construção da safra do linguado é feita sob o prisma das duas categorias nativas de inverno, "que corre seco" e "cum chuva", já que o "linguado dá também cum água doce".

O próprio linguado marca o prenúncio e o fim da safra de linguado. Existem duas categorias cognitivas de linguado: o "linguado de entrada"207, que migra do oceano para o estuário entre os meses de março e abri1 208 "cum pontas de água salgada", no "verão de água salgada" ou "de água misturada"209, e cria expectativas positivas quanto a ocorrência da safra de linguado ${ }^{210}$ no final de abril, e o "linguado de arriada", que migra do norte do estuário para o sul do estuário sendo associado à chegada de "pontas de água doce", em geral, entre outubro e novembro:

O linguado entra na Lagoa quase no final do verão, março-abril, e vai lá pra Lagoa. Adepois ele arreia lá de cima e vem pra nóis aqui. Vem cum ponta d'água. Mas tem aquele que vem do oceano pra nóis aqui, ele vem costiando e entra aqui pra dentro. ( Sr Dino, 67 anos, pescador artesanal).

Tem linguado do oceano que entra cum pontas de água salgada e tem o linguado de arriada também. O linguado de arriada é agora no tempo da

\footnotetext{
207 A identificação entre o "linguado de entrada" e o linguado que "criô" no Saco do Arraial é feita pela cor, o "linguado de entrada" é "bem pintandinho, meio marronzinho, (...), pintinha de amarelo e branco" e o "linguado daqui de dentro" é "bem preto o lombo".

208 Não é por acaso que são os dois primeiros meses que se inicia a predominância do vento "rebojo", segundo a lógica dos pescadores coreanos.

${ }^{209}$ No "verão de água salgada" não há a entrada de linguado do oceano e, portanto, não há prenúncios para sua safra.

${ }^{210}$ A ocorrência do "linguado de entrada" nos meses de março e abril não quer dizer que eles não ocorram durante os meses da sua safra, apenas que nos meses de março e abril o "linguado de entrada" tem o significado de prenúncio da safra e depois não. Mas eles são sempre "linguado de entrada". Ademais, muitas vezes os pescadores ficam "chuliando entrada de linguado" para sair a pescar durante os meses de safra.
} 
curvina também. (...). É agora em outubro-novembro. (Sindo, 40 anos, pescador artesanal).

Por outro lado, a chegada do "linguado de arriada" não é percebida porque o fim da safra de linguado em território coreano geralmente já ocorreu antes:

\begin{abstract}
A pesca de linguado vai até outubro, mais ou menos, setembro-outubro. As veiz a gente num pesca e cumeça setembro-outubro, cumeça esquentando, né. Então cumeça a aparecê siri. Então dá muito siri na rede e rasga muito. Acaba cum a rede o siri. Então a gente pega a pesca mais inté julho-agosto. (...). Pra esquentá é o nordeste. Isso, cumeça a milhorá mais as pesca... cumeça a aparecê mais tainha, mais siri. Tem a curvina também, né. (Evaldo, 39 anos, pescador artesanal).
\end{abstract}

Então cum o frio num aparece quase siri. Cum calor ele (o siri) destrói a rede. Então tem que botá na época fria, né. (...). Quando começa querendo esquentá pra primavera, agosto, por aí, na chegada da primavera, fim de agosto, já pode guardando a rede de linguado. Se teimá ligeiro tá sem rede, o siri corta tudo. Já tem que pescá é o siri, já tem que trocá. (Sr. Rui, 60 anos, pescador artesanal).

O fim da pesca do linguado é marcado, tanto no "inverno cum chuva" quanto no "que corre seco", pelo aumento das temperaturas do ar ('calor'), devido à maior frequência do vento nordeste, entre os meses de agosto e setembro ('Quando cumeça a milhorá mais a pesca... cumeça querendo esquentá pra primavera, [...] fim de agosto, já pode guardando a rede de linguado. [...]. Já tem que pescá é o siri, já tem que trocá’) que, por outro lado, também sinaliza o início da pesca de outros recursos ('cumeça a aparecê mais tainha, mais siri, tem a curvina também').

Já o início da safra de linguado, que geralmente ocorre a partir de abril, é marcado por dois "sinais de memória":

É, abril já começa dando. Fim de safra do camarão. Findô o camarão já podes pegá o linguado que matas. Aí tu faz safra de linguado. É, esfriô-deu! É só esfriá já deu linguado, já deu pro linguado. Que aí ele já começa a caminhá, né. (Gordo, 39 anos, pescador artesanal).

A safra de linguado, que geralmente ocorre a partir de abril, é fundada por dois "sinais" indissociáveis ${ }^{211}$, mas nem sempre simultâneos: o "frio" e o "fím de safra de camarão". Como foi visto em 4.4.1.1.1, o fim da safra do camarão pode se antecipar à chegada do "frio", mas não o contrário. Consequentemente, quando estes "sinais" não trabalham simultaneamente na construção do tempo do "inverno", o "fim da safra de ${ }^{211}$ O “frio" e o "fim da safra de camarão" são sinais indissociáveis apenas no cenário de "verão de água
salgada" ou "de água misturada". 
camarão" marca o início de um tempo de espera pela chegada da safra de linguado. Por outro lado, se o "verão" é "de água doce", não há safra de camarão e, portanto, será apenas o "frio" a marcar o início da safra do linguado.

Durante a safra de linguado, há um "sinal" que gera expectativa quanto a qualidade da safra de linguado é a presença de "lixo-capim"212: "O lixo-capim é bom pra qualqué peixe, no caso, porque segura, né. O peixe fica ali no meio e num sai, né. Ele tem cumida, que nem agora no inverno, ele tá no meio do quente. (...). O ano que tem lixo tem fartura" (Moisés, 45 anos, pescador artesanal). Como foi visto para o camarão, o "lixo-capim” dá em "água misturada”, portanto, é provável que a presença dele no "inverno" esteja condicionada ao "inverno de pouca chuva".

Para a construção do calendário de pesca na Coréia, o ciclo de pesca do linguado dentro do estuário, que se contextualiza em qualquer uma das duas categorias de "inverno", fundamenta marcos etnocronológicos com dois momentos principais: o início da pesca do linguado a partir do "frio", entre os meses de abril e de maio, e do "calor", entre os meses de agosto e setembro.

O desdobramento das "safras de verão" e das "de inverno" são as bases para a construção do "verão" e do "inverno" e, consequentemente, do calendário de pesca coreano, assunto do próximo item.

\subsubsection{O "inverno" e o "verão"}

Como pode ser visto, os "sinais de memória" que materializam os "prazos" das safras articulam a dinâmica estuarina, através das suas principais forçantes (ventos e chuvas), com o ciclo biológico das espécies pescadas nas águas da Coréia. O mecanismo de articulação segue o princípio de causa-efeito.

Mais do que a ordenação de uma simples interface entre fatores bióticos e abióticos, isto implica que a construção e a ordenação do ciclo de pesca coreano perfaz

\footnotetext{
${ }^{212} \mathrm{O}$ "lixo-capim" (Ruppia maritima) são pradarias de fanerógamas submersas que formam hábitats vitais para a criação de invertebrados e peixes (COSTA, 1998).
} 
a mesma ordenação do ciclo estuarino: as "safras de inverno" como princípio e as "de verão" como fim:

Primeiramente a gente pegava com peixe-rei. Bom, entrava fim de maio a gente começava já pescando o peixe-rei. Aí ia até agosto. Quando era agosto a gente parava. (...). Então aí nóis passava pro bagre, o bagre e a curvina. Aí do bagre e da curvina passava pro camarão. Por fim, a tainha de corrida. (Sr. Dino, 67 anos, pescador artesanal).

Neste sentido, a estrutura cognitiva dos "anos de...", assim como seus constituintes fundamentais ('invernos...' e 'verão de...'), imbui-se não só de significado hidrodinâmico, mas também biológico. Assim, na Coréia têm-se quatro ciclos de pesca possíveis articulados às três possibilidades do ciclo estuarino que se engendram em três possibilidades etnocronológicas de calendário ${ }^{213}$.

Apesar da principal característica fundadora do "inverno" ser o "frio", ele é fundado pelo término das "safras de verão". O "inverno" fundado pelo "frio" abre duas possibilidades de futuro: "inverno que corre seco" ('de água salgada') e o "inverno cum (pouca ou muita) chuva". O "inverno cum muita chuva" impede a safra de peixe-rei, enquanto a categoria "inverno que corre seco" e a subcategoria "inverno cum pouca chuva" favorecem a ocorrência de todas as "safras de inverno". Neste sentido, a partir destas duas categorias de "inverno" há duas possibilidades de "safras de inverno", uma com e outra sem peixe-rei. Esta variação vai dar um ciclo de pesca a mais do que a quantidade de ciclos estuarinos.

O "calor", por sua vez, abre duas possibilidades de "primavera" a partir de qualquer um dos "invernos": a "primavera que corre seca" e a "primavera cum muita chuva". A "primavera" é um período de espera pelo "verão" com intensa observação dos ventos, da água e da Lua nova, considerada fundamental para prever as chuvas durante a "primavera".

Seja qual for a categoria de "inverno", se subsequentemente ocorrer a "primavera cum muita chuva" as safras de corvina, bagre e camarão não ocorrem sendo o "verão" fundado pela safra de siri e/ou tainha. Vale lembrar que, para os especialistas na pesca do siri e da tainha, o aumento da abundância do "siri" e da tainha a partir dos meses agosto e setembro já bastam para inaugurar o "verão". Neste caso, a "primavera junta com o verão", inaugurando um "verão de água doce" e um "ano de água doce”. O

\footnotetext{
${ }^{213}$ Neste sentido, a incorporação do viés biológico para as categorias "anos de..." densifica a percepção do tempo em espiral discutido na etnocronologia estuarina.
} 
término do "ano de água doce" ocorre com a chegada do "frio" no mês de maio reinciando um "ano". O outono, por outro lado, não há possibilidade de se agregar ao inverno (Figura 11).

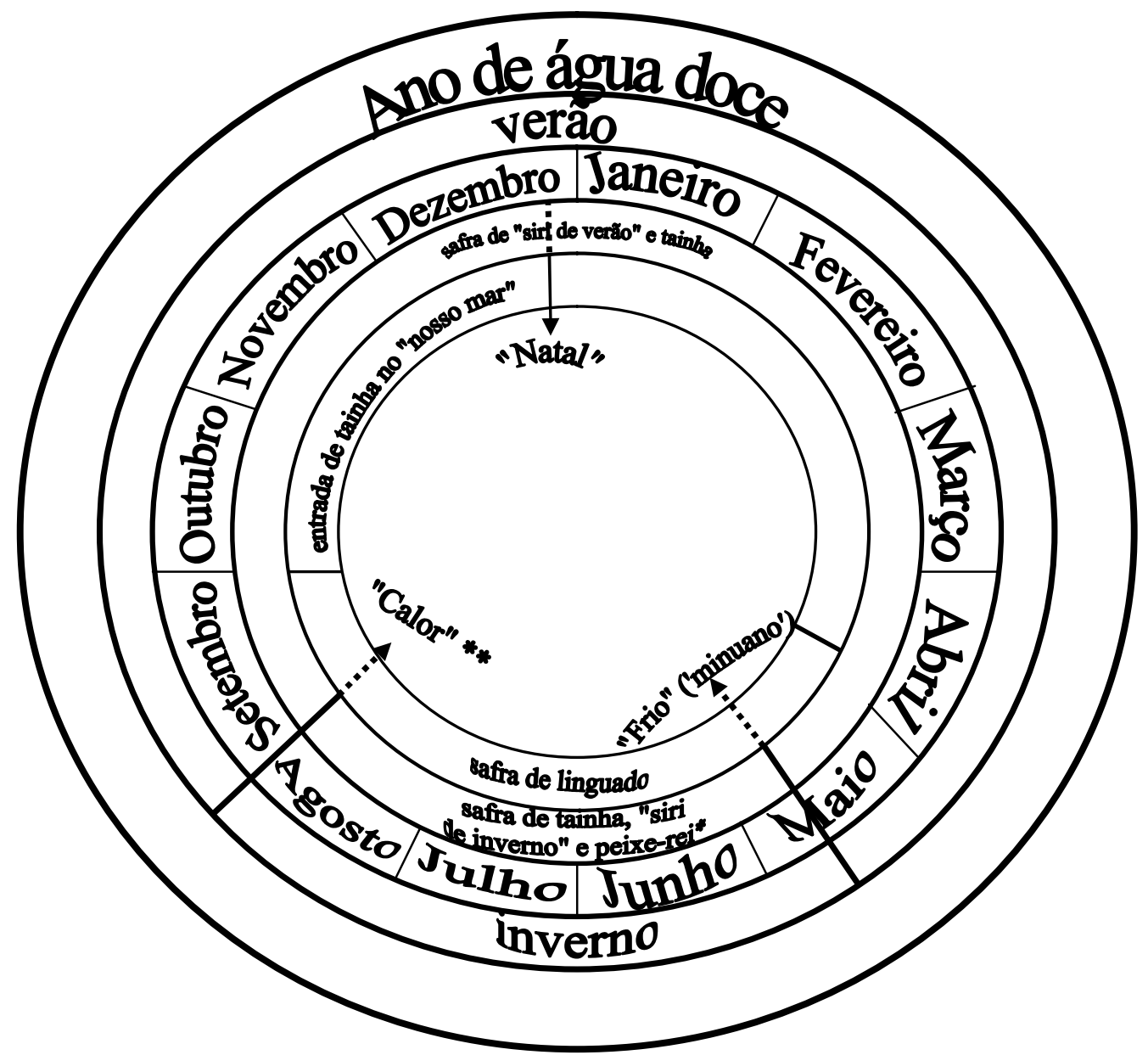

*safra de peixe-rei só ocorre se o "inverno" for "cum pouca chuva".

** aumento da abundância de siri e de tainha em nosso mar.

Figura 11: Calendário etnocronológico do "ano de água doce".

Se o "inverno é cum pouca chuva" e a "primavera corre seca", entre os meses de agosto e setembro as águas do "nosso mar" já começam a salgar, o que possibilita as safras de bagre e corvina a partir do dia 15 de agosto $^{214}$ e o início das safras de camarão entre setembro e novembro inaugurando o "verão de água salgada" e o "ano de água salgada". Se o "inverno corre seco", as mesmas categorias de "verão" e de "ano" são fundadas, porém as safras de corvina e de bagre não ocorrem devido à ausência de "reponte". Para os pescadores especialistas na pesca do siri e da tainha o "verão" é fundado ao mesmo tempo da entrada dos pescados com a "ponta de água salgada" à

\footnotetext{
${ }^{214}$ Para ocorrer as safras de corvina e de bagre é necessário o "reponte”, ou seja, no caso do "ano de água salgada" o "inverno" tem que ser "cum pouca chuva".
} 
partir de setembro. Assim, para qualquer uma das especialidades, pelo menos uma parte da "primavera junta com o verão". O "ano de água salgada" normalmente é abolido pelo frio em maio, mas abre possibilidades para a antecipação ou o adiamento do término. $\mathrm{O}$ prolongamento pode ocorrer através da "tainha de corrida" na minguante de junho. Já o término precoce das "safras de verão" em todo o estuário pode ocorrer através de chuvas e, nas águas da Coréia, através da gradativa migração de "peixe" "lá pra cima" provocada pela "água salgada" ou intensa migração de camarão provacada pelo vento noroeste, gerando escassez e inaugurando antecipadamente o "inverno", entre março e abril. Neste caso, parte do outono ${ }^{215}$ se agrega ao "inverno" reiniciando um "ano" (Figura 12).

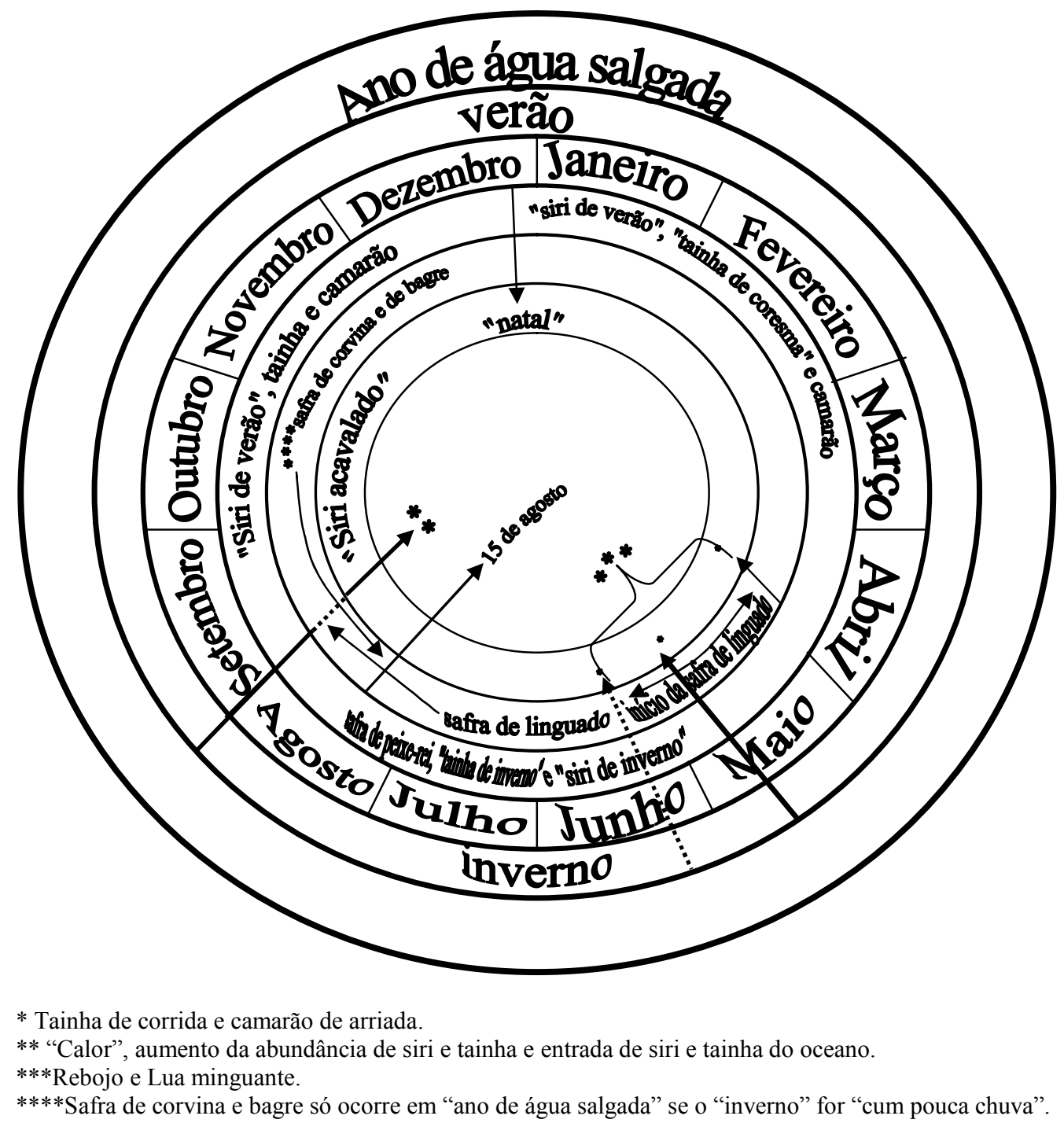

Figura 12: Calendário etnocronológico do "ano de água salgada"

${ }^{215}$ A estação conhecida como outono, não faz parte da estruturação cognitiva dos coreanos. A citação dele é para que se referencie o período de tempo maleável que ora é do "inverno" e ora é do "verão". 
Se, por fim, o "inverno é cum muita chuva" e a "primavera corre seca", a entrada de "pontas de água salgada" ocorre entre os meses de outubro e dezembro ('Natal'), o que possibilita as safras de bagre e corvina a partir de outubro e o início da safra de camarão entre novembro e janeiro inaugurando o "verão de água salgada" ou "de água misturada" e o "ano de água misturada". Para os pescadores especialistas na pesca do siri e da tainha, o "verão" é fundado ao mesmo tempo da entrada destes pescados com a "ponta de água salgada". O "ano de água misturada" pode ter seu fim com o frio de mês de maio, porém abre possibilidades de antecipação ou, mais provavelmente, o adiamento do término do "verão". O prolongamento do "verão" até o início do mês de junho pode ocorrer devido à presença de "lixo-capim" e da ZM mais próxima da Ilha dos Marinheiros, materializado na chegada de "pontas de água doce" e de "pontas de água salgada", gerando a concentração de grande quantidade de pescados e de tamanho considerado "bom" nas águas da Coréia ou ainda através da minguante de junho. Neste caso o "verão" sobrepõe-se ao "inverno". No entanto, a antecipação pode ocorrer através da ocorrência de chuvas e/ou vento noroeste entre março e abril. Neste último caso, parte do outono se agrega ao "inverno". Em qualquer uma das duas possibilidades, terminada as safras de "verão" re-inaugura-se um "inverno" (Figura 13). 


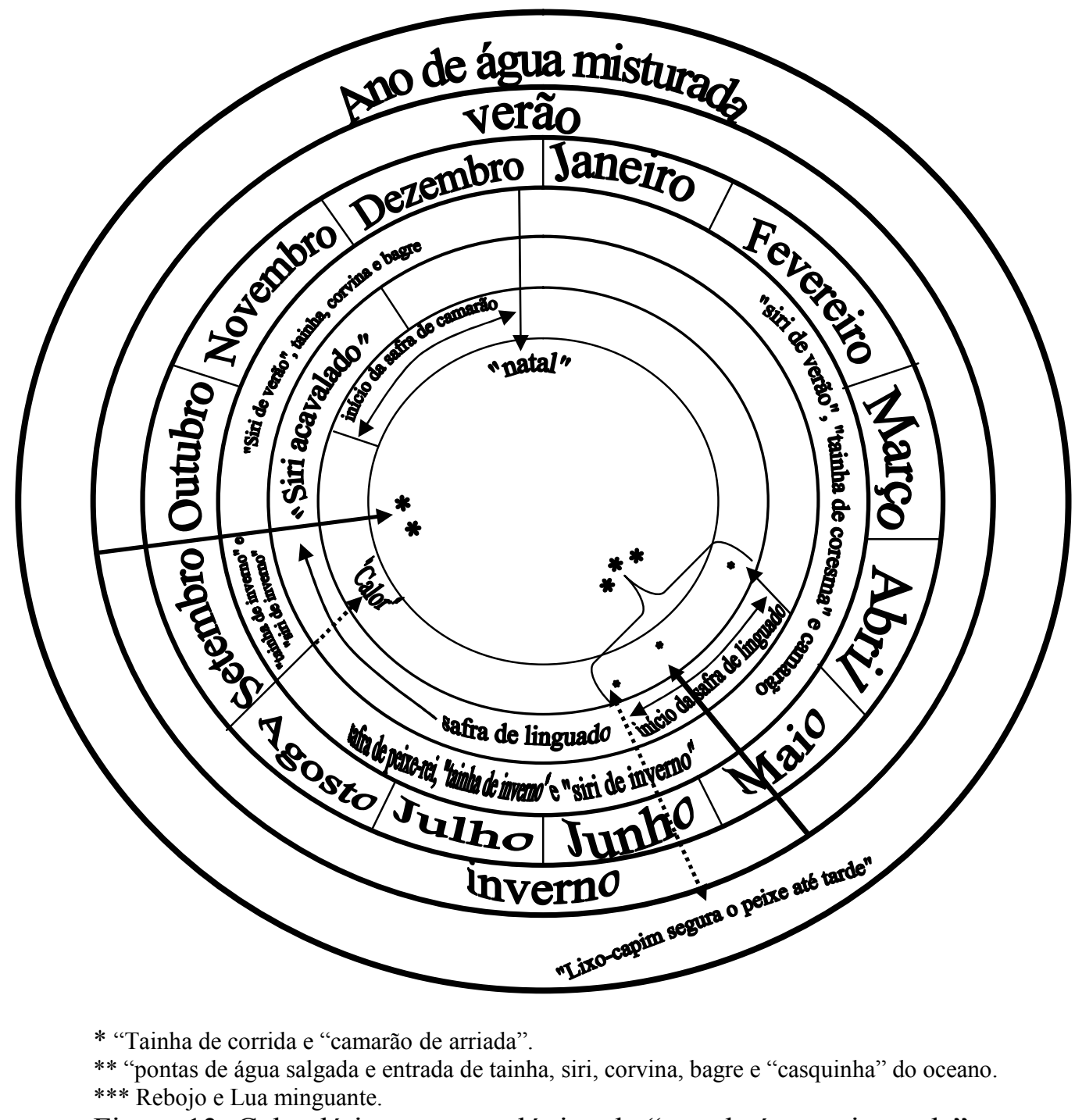

Figura 13: Calendário etnocronológico do "ano de água misturada".

Portanto, nos calendários etnocronológicos da Coréia não existe outono, por outro lado existe uma "primavera". Em todas as categorias de "anos" a "primavera" "é a decisão!" para as "safras de verão", sobretudo à do camarão, e para definição de cenários hidrodinâmicos e biológicos, os "anos de...". A "primavera", porém, não ganha autonomia de estação: é apenas uma extensão do "verão" ou do "inverno", assim como o período de tempo equivalente ao outono. Em alguns "anos", há ainda a sobreposição do "verão" sobre o "inverno". Esta referência à duração elástica das estações também foi encontrada por Souto (2004) entre os pescadores e marisqueiras de Acupe (BA). Segundo Kagame (1975), entre o povo Bantu, o tempo marcado pelo fato concreto pode ser curto ou longo segundo a duração do evento que o individualiza. Portanto, a divisão, como é característica de tempo cíclico, não é fixa, mas tão fluida quanto a hidrodinâmica estuarino-lagunar, graças aos "sinais de memória" que, sucessivos e/ou sincrônicos, vão (des)construindo safras e estações ao ciclo do tempo. 
No caso da Coréia a duração das estações "inverno" e "verão" se dá em função das "safras de verão". O "inverno" é, antes de tudo, marcado pela desconstrução e subsequente construção das "safras de verão". Por isso, normalmente, o "inverno" encampa um tempo maior que o tempo das "safras de inverno", entretanto jamais o "verão" será maior que a duração das "safras de verão". A duração equivalente a parte do outono ou da "primavera" se agrega ao "inverno" em função do término precoce ou do prolongamento das "safras de verão".

As safras de inverno, por sua vez, são construídas em função da ocorrência ou não de chuvas no período do "inverno" e, a partir dele, projeta-se o futuro, ou seja, a construção do "ano".

O "ano" também gira em torno das "safras de verão". A sequência temporal da construção do "ano" a partir do "inverno" tem o sentido de construção das "safras de verão". Vale ressaltar que o "ano" pode ter a duração menor ou até maior de 12 meses, basta que o outono se junte ao "verão" e, depois, ao "inverno" de "anos" subsequentes ou ao "inverno" e ao "verão" do mesmo "ano", respectivamente.

O "verão" também é a principal estação de pesca nas comunidades de pesca costeiras de Alagoas (FORMAN, 1970) e de São Paulo (CALVENTE, 1993) e estuarinas da Bahia (SOUTO, 2004) e do Rio Grande do Norte (MILLER, 2005). Em todos estes locais, segundo os mesmo autores, o "verão" é a estação de maior duração. Além disso, Miller (2005) nota que as atividades de pesca e de plantação dos pescadores são organizadas em função dos pescados de "verão".

Cunha e Rougeulle (1989) argumentam que a atribuição de significados aos recursos naturais ocorre de acordo com o conhecimento da variedade de espécies, do seu ciclo reprodutivo e de seus hábitats bem como, segundo Cunha (1988), ao valor econômico dos pescados, já que o seu trabalho só se realiza socialmente no mercado. Neste sentido, na Coréia, já que os recursos pesqueiros de maior valor de mercado, cujos ciclos percebidos perfazem sua presença ou maior abundância e qualidade (tamanho) no "verão", constróem o "ano" centrado nas "safras de verão".

Há, por outro lado, períodos datados aparentemente fixos como o 15 de agosto e o "Natal". Estes marcos são apropriados segundo a lógica da experiência temporal do grupo, que é flexível. Por isso, é "de 15 de agosto em diante...”, "perto do Natal...” ou “...até o Natal". Estes referenciais datados servem de marcos que fornecem "prazos" em 
torno do qual podem ocorrer determinados eventos. Situação semelhante é registrada por Elíade (2004) em comunidades pagãs agrícolas no sul e sudeste da Europa no séc. XIX, em que a apropriação do calendário fixo e católico segundo a lógica das tradições resultou num "cristianismo cósmico".

Portanto, o "inverno...” e o "verão de...", e todas as suas combinações possíveis para a construção dos "anos de...", e os "anos de..." estão imbuídas, além de hidrodinâmico, de significado biológico. Do ponto de vista etnooceanográfico, são padrões construídos da dinâmica estuarino-biológica do "nosso mar", na interação entre as principais forçantes estuarinas (ventos, chuvas e, secundariamente, a Lua) e as forçantes biológicas (ciclo de vida dos 'peixes'), para mantê-la dentro de um espectro "normal" de variação caótica e constituir "pano de fundo" para a tomada de decisões e ação na pesca.

Há ainda mais um fator que influencia os "cenários" que merece destaque: a tentativa do IBAMA de impor um calendário de pesca fixo no estuário da Lagoa dos Patos através da Instrução Normativa Conjunta de 2004 (INC, 2004). A INC atua em três momentos: primeiramente na liberação da pesca da tainha e da corvina a partir de outubro, em seguida na liberação da pesca do camarão em primeiro de fevereiro e finalmente na proibição de todas as pescas a partir de primeiro de junho ${ }^{216}$.

No entanto, é apenas uma tentativa de imposição de um calendário. Segundo Michel de Certeau: "O cotidiano se inventa com mil maneiras de caça não autorizada" (1996: 38). As astúcias da "antidisciplina" proporcionam formas de reapropriação do espaço organizado pelas estruturas dominadoras. Na Coréia também se cria "mil maneiras" de se reapropriar do espaço e do tempo, materializado no espaço, imposto pelo IBAMA. Antes da abertura oficial da safra, a pesca irrompe de acordo com a lógica da experiência temporal do grupo: "Tendo camarão de tamanho bom pra gente pescá, a gente pesca" (Amarildo, 40 anos, pescador artesanal), ou seja, camarão de tamanho considerado "bom" é um "sinal de memória" que define o início da pesca do camarão. No entanto, nas “andanas” as redes ('saquinho') são colocadas em menor número, as de piores estado de conservação e mais próximo à costa da ilha. Um estado de alerta constante é mantido pelos pescadores aos sons das embarcações do "mar" para que não sejam surpreendidos pelo IBAMA.

\footnotetext{
${ }^{216}$ Segundo a INC (2004), a pesca da corvina estaria proibida a partir de março, porém na Coréia a pesca da corvina cessa, no máximo, no "natal".
} 
Além disso, os mecanismos de mercado também estimulam a pesca do camarão através do aumento dos preços de compra durante o período em que a pesca está proibida. Adverso a lógica da experiência temporal do grupo e da lógica de mercado as quais os pescadores se mantêm articulados, o marco regulatório gera também uma cultura da ilegalidade.

Após o dia primerio de fevereiro, o clima de atividade pesqueira tenso vai dando lugar a um clima mais descontraído. De um ritmo de trabalho "ilegal" passa-se a um "legal".

O término da safra de camarão para o dia primeiro de junho em geral não traz problemas, pois está em consonância com qualquer um dos calendários etnocronológicos (ver Figuras 11, 12 e 13). Há exceção, em "anos de inverno quente e seco", quando a pesca de camarão entra "inverno" adentro. Também neste caso, os pescadores da Coréia se utilizam das táticas de "antidisciplina" descritas acima para a realização da pesca do camarão em período proibido por lei.

Já a normatização para os outros pescados é como se praticamente não existisse: "Tendo peixe bom pra pescá, a gente pesca"217. Desta afirmação se desdobra duas situações: mesmo quando os "sinais de memória" indicam a fundação de determinada safra antes do período permitido, a legislação não é levada em consideração, como é o caso da tainha e da corvina; e o caso do bagre em que houve o colapso dos seus estoques ${ }^{218}$ : "Se desse bagre todos os anos desse jeito, essas lei ia estrová nóis" (Sr. Meca, 68 anos, pescador-lavrador). Portanto, se não tem "peixe" suficiente para pescar não se funda safras daquela espécie, mas se houvesse, provalvelmente, as táticas de antidisciplina também vigorariam para a manutenção do calendário etnocronológico.

As divergências com o IBAMA acerca de calendários de pesca, sobretudo do camarão, estão amplamente documentadas em várias regiões do Brasil como em São Paulo (CALVENTE, 1993), no Rio de Janeiro (COSTA, 1992) e no Rio Grande do Sul (ADOMILLI，2002; KALIKOSKI，2002; PASQUOTTO，2005; ALMUDI，2005; BARENHO, 2008). Segundo Costa (1992), os pescadores da baía de Sepetiba adotam estratégias, como a pesca noturna, por exemplo, para burlar a fiscalização do IBAMA que tenta impor um calendário formal de pesca de camarão.

\footnotetext{
${ }^{217} \mathrm{O}$ "peixe bom" se refere à quantidade e à qualidade (tamanho) consideradas aceitáveis pelo grupo.
} ${ }^{218}$ A partir de meados dos anos oitenta, ninguém mais pescou bagre na Coréia devido a sua escassez. 
A incidência da INC (2004), ainda que não gere mudanças nos "prazos" das três possibilidades etnocronológicas do calendário, agrega um novo elemento social em qualquer um dos cenários de pesca ('anos de...'). Neste sentido, além do teor hidrodinâmico e biológico, em cada uma das possibilidades etnocronológicas de calendário perpassa os efeitos da INC (2004) que, como foi visto, é apropriado segundo a lógica do grupo e re-inserido no cotidiano da comunidade gerando um resultado diverso àquele proposto em lei.

Há ainda os "sinais" que "estabelecem prazos" na construção do ciclo fundamental de tempo na pesca: o ciclo diário. Porém, entre as estações do "ano", há algumas variações dentro deste ciclo. É o que será descrito a seguir.

\subsubsection{Ciclo diário sazonal}

\footnotetext{
"Legiões sombrias erguem-se no horizonte. A luz morna que outrora imperava sobre o firmamento boceja melindrosamente diante das despertas sombras caprichosas do poente". (Rascunhos do caderno de campo).
}

O ciclo diário de pesca predominante na Coréia é o "de sol a sol" para todas as pescarias. O ciclo "de sol a sol" significa que a "mareada" inicia-se com o "sinal" da "boca da noite" (crepúsculo) e termina com o da "barrinha do dia" (aurora). Ou seja, a pesca na Coréia ocorre predominantemente no período noturno, sendo a transição entre dia e noite ('boca da noite') e noite e dia ('barrinha do dia') um período de intensa movimentação de chegada no "mar" e de saída do "mar", respectivamente.

Para ser mais preciso, o que ocorre, na verdade, é que antes da "noite fechada", ou seja, antes do último raio de sol desaparecer, as redes têm que ser colocadas. De manhã, as redes têm que permanecer pelo menos até o aparecimento dos primeiros raios de sol ('barrinhas do dia'). Isto porque o ritmo de pesca se articula ao ritmo biológico das espécies a serem pescadas: "Quando o sol entra (pôr-do-sol) ou quando ele sai (nascer-do-sol) ele mexe cum os bixo, ele mexe cum a terra. Tudo se movimenta..." (Guega, 54 anos, pescador artesanal). Segundo Marques (1991), o maquinário cognitivo dos pescadores percebe e se apropria deste surto de atividades animais do mundo "real" como uma forma de se programar adaptativamente à sua presa.

Por vezes a pesca ocorre no período diurno. A saída ocorre predominantemente no período matutino antes das $10 \mathrm{~h}$ da manhã e o retorno ocorre apenas quando se 
capturou uma quantidade considerada boa de pescados ou quando os mantimentos acabam, o que, normalmente, não passa de um dia.

Em outros lugares do Brasil, como no Pará foram registradas pesca no período diurno apenas, sendo a aurora e o crepúsculo marcos para saída e o retorno da atividade pesqueira, respectivamente (SILVA, 2006). No litoral de São Paulo foram registradas pescarias noturnas, enquanto no Paraná (CUNHA, 2007), Santa Catarina (SC) e no Rio de Janeiro (COSTA, 1992) foram registrados a pesca nos dois turnos, assim como na Coréia. Em São Lourenço do Sul (RS) são as "parelhas pequenas" que executam o ciclo diário e noturno da pesca, ao passo que as "parelhas grandes" executam a pesca em vários dias.

O maior rigor no cumprimento deste ciclo, pois é reproduzido rigorosamente todos os dias, se dá na pesca do camarão que, como foi visto, ocorre no "verão", estação de dias longos. Isto torna o ritmo de pesca nesta estação um tanto frenético. As saídas do mar nas "barrinhas do dia" ganham fôlego no "verão", devido à atuação dos atravessadores para o recolhimento do pescado nas adjacências da estrada que circunda a Ilha dos Marinheiros no início da manhã.

Há variações, no entanto, entre as categorias de "verão". Se o "verão é de água doce" não há pesca de camarão e diminui a abundância de tainha, o que arrefece o ritmo da estação. Se o "verão" é a principal estação de pesca e renda para os coreanos, disso resulta que o "verão de água doce" cria um cenário cotidiano desolador. Os dois outros cenários de "verão" se diferem pelos "prazos" em que se funda a safra de camarão: prolongando ou antecedendo a safra do camarão (Figura 11, 12 e 13).

A Lua também dita o ritmo das práticas da pesca no seu ciclo diário. Após o pôr-do-sol e antes do nascer-do-sol é a "Lua de saída" e a "Lua de entrada", respectivamente, que se "chuleia" na utilização de petrechos móveis, sobretudo como será visto logo adiante, para o lance de tainha. No entanto, no primeiro dia de qualquer uma das Luas, o pôr-do-sol e a saída da Lua ocorrem quase simultaneamente que, diariamente, com o atraso de quase uma hora da saída da Lua (ver item 4.2.2), vão aumentando o hiato entre eles. 


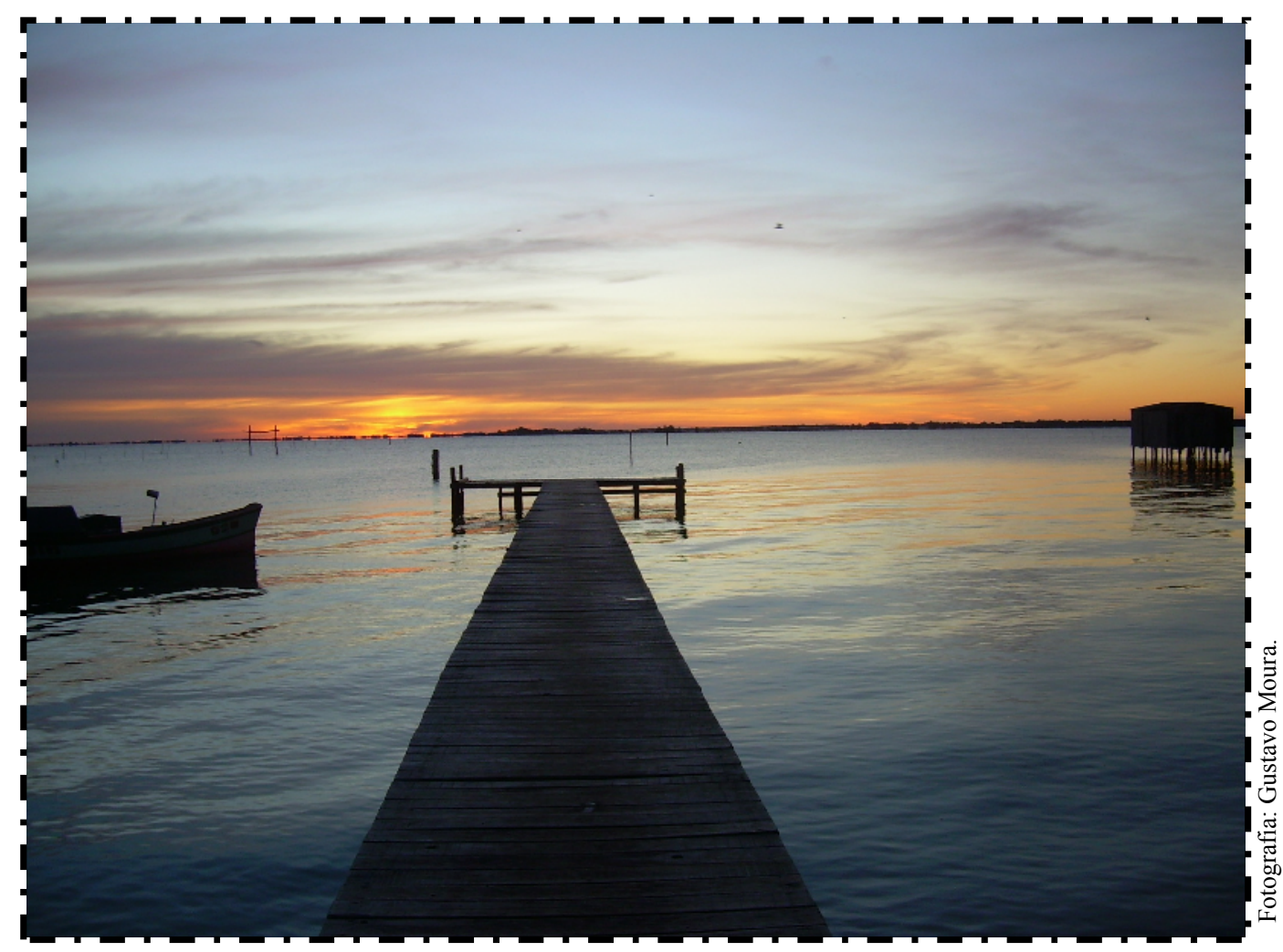

Figura 14: As "barrinhas do dia".

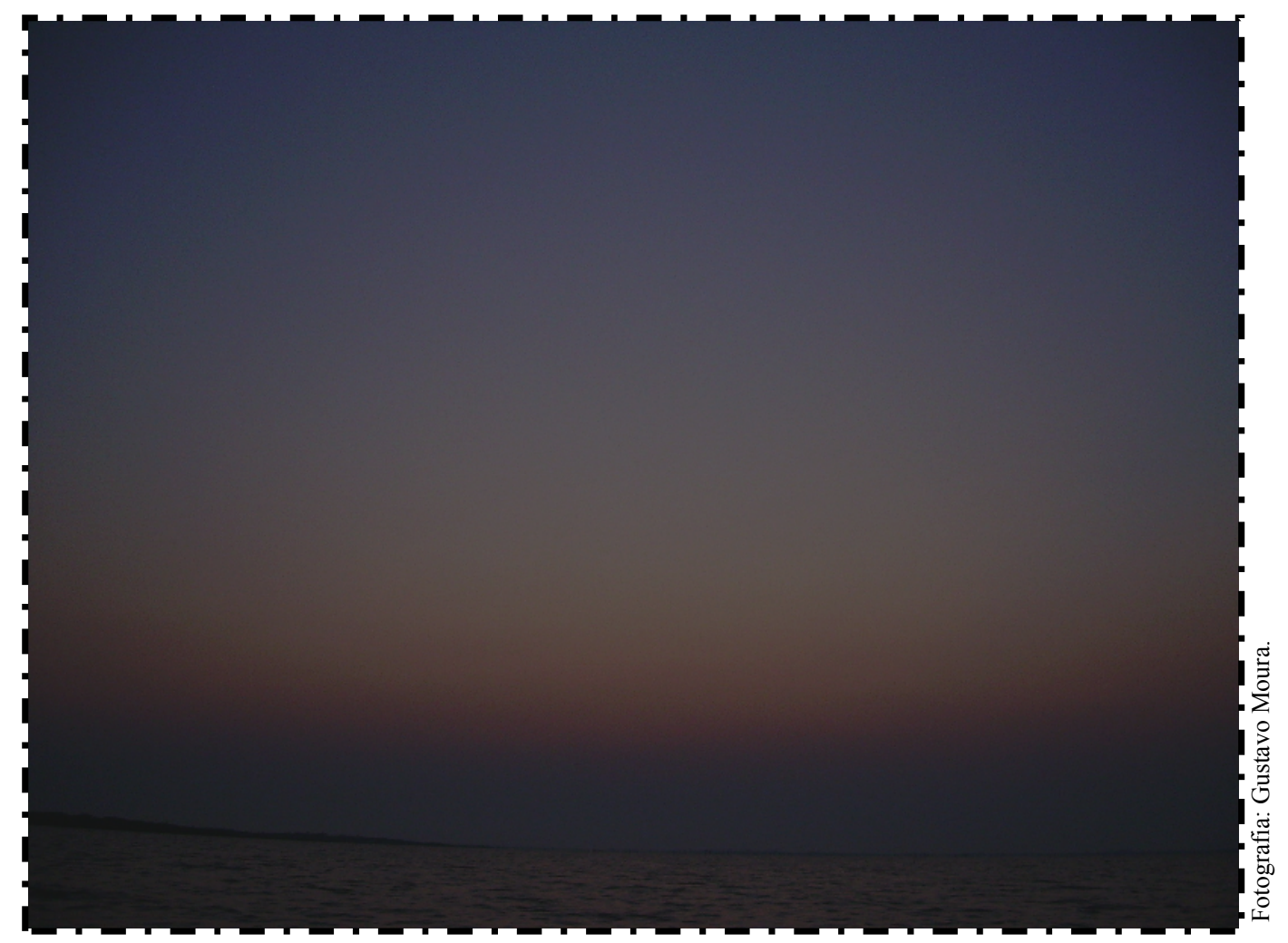

Figura 15: A "boca da noite" ('noite quase fechada').

Embora em qualquer uma das categorias de "inverno" os referenciais para o ciclo diário continuem sendo os mesmos, inaugura-se um tempo mais lento. As noites são maiores, portanto, o tempo disponível para a "mareada" é maior, e, a ausência da 
"safra de camarão", permite um ritmo menos intenso de trabalho no "nosso mar", embora mais longo. O pescador está sempre "chuliando" a "monção de tempo" para ir pescar. O tempo de espera ganha uma importância ainda maior.

Ainda que se inaugure o "inverno quente e seco", a pesca do camarão não ocorre rigorosamente todos os dias, o que mantém um ritmo mais intenso do que nos outros "invernos", porém menos frenético do que no "verão": "Teve inverno aí que eu passei o inverno todinho pescando camarão. A gente num ia todos os dia, mas passemo todo ele pescando camarão" (Sr. Zezinho, 60 anos, pescador-agricultor). Não há atravessadores e, por isso, os pescadores se sentem mais a vontade "pra culhê as rede" a qualquer momento depois das "barrinhas do dia".

O "inverno cum muita chuva" é ainda mais lento. Só é possível a pescaria de linguado, tainha e siri, sendo que estes dois últimos diminuem sua abundância em função do frio e da água doce.

Por isso, a sensação que se tem é de uma duração maior do "inverno" que do "verão": "O inverno é longo, a gente fica parado... No verão o cara tá sempre trabalhando, o tempo passa mais ligeiro" (Guega, 54 anos, pescador artesanal).

Na Bahia (SOUTO, 2004) e no Rio Grande do Norte (MILLER, 2005), os pescadores também vivenciam ritmos mais intensos no "verão" e mais flexíveis no “inverno". No Ceará, Forman (1970) além dos ritmos diferenciados entre o "verão" e o "inverno", verifica um desfasamento do ciclo diário de pesca: o início e o fim que eram entre as $3 \mathrm{~h}$ da manhã às $4 \mathrm{~h}$ da tarde no "verão", passam a ser entre às $11 \mathrm{~h}$ da manhã e $11 \mathrm{~h}$ da noite no "inverno", no caso da pesca de "jangada".

Aos "cenários" ainda se engendram outros "sinais de memória", no processo de tomada de decisões, que irrompem em movimentação e ações dos membros da comunidade na pesca. Portanto, os "cenários" permitem que o pescador se adapte às “(re)configurações” de seu mundo de pesca. É o que será descrito nas Tomadas de decisão e ações na pesca. 


\subsubsection{Tomadas de decisão e ações: "A pesca é bom um certo jeito de água”.}

Segundo Allut (2000) e Ruddle (2000), para as tomadas de decisão na pesca, é necessário saber "quando", "como" e "onde” pescar. Neste sentido, aos "cenários", além dos que estabelecem prazos, vários outros "sinais de memória" se engendram para a construção das tomadas de decisão de "quando", "onde" e "como" pescar. Por isso, cada um dos processos de tomadas de decisão das respectivas safras encontra seu tempo no calendário de pesca descrito no item 4.4.1. A espera para que o ecossistema tome o seu tempo é satisfeita assim que a confluência de "sinais de memória" constrói este "tripé" irrompendo na movimentação dos membros da comunidade e na ação que, finalmente, segundo Kagame (1975) e Panikkar (1975), condensa o tempo percebido. Este item é dedicado à construção das tomadas de decisões e ações a partir dos "sinais de memória" que, na verdade, são específicos para cada pescado, porém um padrão geral é descrito e ilustrado pelas safras de tainha, camarão e linguado.

Allut (2000) argumenta que o meio natural é cenário de ação e fonte de problemas e a natureza desses problemas é que determina o tipo de necessidade cognitiva de que o pescador precisa. Basta que os cenários configurados pelos coreanos abrem um espectro de possibilidades de construção de decisões e de ações dentro dos ciclos "anuais", sazonais e diário de pesca, em resposta à dinâmica relacional entre os processos hidrodinâmicos e os biológicos. Para Wilson et al (2004), o desenho de regras de processos biológicos básicos tem a função de manter a pesca dentro de um espectro de variação caótica (domesticação do ambiente) que enfatizam "como", "onde" e "quando" os peixes poderiam ser pegos.

Dentro da escala "anual" e "sazonal", como foi visto no item 4.4.1.3, cada cenário representa a fundação ou não de safras, mas há ainda diversos referenciais no mar, em terra e no céu (continuum entre mar, terra e céu) que prenunciam o início ('linguado de entrada', Lua nova da 'primavera', etc.) e o fim ('camarão de cola azul', 'aranhola', 'maricá', 'tainha de corrida', etc.) de safras e que avaliam as condições de safra ('butiá', 'araçá', ‘mosquito', etc.). Em São José do Norte (RS), pescadores adotam as margaridas amarelas como referência para o prenúncio de boa safra de corvina (ADOMILLI, 2007). 
Segundo Allut (2000), somente o conhecimento profundo da dinâmica meteorológica sobre os aspectos relacionados à pesca permite um certo controle sobre o meio e, até certo ponto, fazer previsões. No caso da Coréia, os "sinais" de prenúncio, não só mostram um profundo conhecimento dos aspectos meteorológicos, mas implicações das interações entre os aspectos meteorológicos, astronômicos e hidrodinâmicos sobre a ocorrência ou não de determinada safra (continuum entre mar e céu). Já os sinais de monitoramento da qualidade da safra correlata manifestações biológicas terrestres e aquáticas, segundo aspectos meteorológicos favoráveis a tais manifestações (continuum entre mar-terra-céu). Cunha (2007) pontua que a trama de significações que emerge da unidade espacial terra-mar-céu apropriada pelos pescadores paranaenses atua como regulador de acesso aos recursos naturais e a movimentação no espaço marítimo. Em consonância, na Coréia a apropriação de microáreas de abundância, e de sua dinâmica, é o mecanismo de estruturação do acesso aos recursos pelo grupo, que territorializa, e das tomadas de decisão para a pesca.

Em cada cenário "anual” ou "sazonal”, desde que as condições hidrodinâmicas favoreçam a ocorrência de determinada safra, desenvolvem-se três padrões migratórios de qualquer uma das espécies: entre o oceano e o estuário, entre cabeceira e baixo estuário (entrada e saída do território coreano) e entre "fundo" e "baixo". Silvano et al (2006) descrevem quatro padrões de migrações para os recursos pesqueiros do litoral brasileiro dentre os quais dois são observados na Coréia: o primeiro e o último. A migração entre "cabeceira" e "baixo" estuário foi registrada por Seixas e Berkes (2003), segundo o conhecimento tradicional de pescadores de Ibiraquera (SC), para todos os recursos pesqueiros daquele estuário, entre os quais a tainha e o camarão.

Cada um destes padrões de migrações contribui de forma diferenciada para a construção das tomadas de decisões e ações:

1. Migração oceano-estuário

1.1. Quando => safras de "tainha de corrida", "camarão de arriada", bagre e corvina; 
1.2. Como $=>$ Posicionamento das redes "atravessado" ('tainha de corrida') ou na vazante ('camarão de arriada ${ }^{219}$ );

1.3. Onde $=>$ "Aqui dentro" ou "ali fora"

2. Migração entre cabeceira e baixo estuário ('sai daqui e vai lá pra cima e depois vem de volta')

2.1. Quando => Quando pescar "aqui dentro";

2.2. Como $=>$ Posicionamento das redes "na feição" para a pesca do siri e do camarão;

2.3. Onde $=>$ "Aqui dentro" ou "ali fora"

3. Migração entre "fundo" ('lameirão') e "baixo" ('croa')

3.1. Quando => Qual dia sair para pescar "aqui dentro";

3.2. Como $=>$ Procura pelo pescado (petrechos fixos e móveis) e posicionamento das redes fixas "ao correr" (linguado, camarão, tainha) ou "atravessado" (tainha).

3.3. Onde => "Em cima da croa", "beira de croa" ou "lameirão".

Em grande parte, portanto, a permanência "aqui dentro", as saídas "ali fora" bem como o retorno dos pescadores "aqui pra dentro", ou seja, a movimentação dos pescadores da Coréia se dá em função do ciclo migratório das espécies pescadas a partir de sua entrada em ou passagem ('quando') pelo território coreano ('ali fora' ou 'aqui dentro' $)^{220}$. Porém, é, sobretudo, no padrão migratório "croa"-"lameirão" que a pesca tem sua unidade fundamental de tempo (ciclo diário de migração) e de espaço ('lameirão'-‘croa') nas tomadas de decisão. Neste sentido, Maldonado (1988) e Cunha e Rougeulle (1989) avaliam que o fundamento da movimentação na atividade pesqueira obedece aos ciclos biológicos conhecidos dos recursos territoriais bem como de sua disponibilidade.

Como todos os recursos pesqueiros perfazem o movimento migratório "croa""lameirão", os petrechos são usados geralmente "em cima da croa", "no lameirão" ou

\footnotetext{
${ }^{219}$ Vale lembrar que, para alguns pescadores, o "camarão de arriada" não migra para o oceano. Nesta concepção, o "camarão de arriada" deve ser posto na categoria de migração entre cabeceira e baixo estuário.

${ }^{220}$ A entrada no território coreano ou a passagem por ele ocorre tanto por recursos pesqueiros que realizam o padrão migratório cabeceira-baixo estuário ou oceano-estuário.
} 
entre a "croa" e o "lameirão" ('em beira de croa') dependendo da espécie alvo. No entanto, como foi visto no item 4.4.1.4, a atividade pesqueira ocorre a partir do crepúsculo até a aurora ('de sol a sol') articulado à migração do pescado do "lameirão" para a "croa" e da "croa" para o "lameirão", respectivamente. A partir disso, os petrechos são colocados "em cima da croa" ou na "beira de croa".

No entanto, diversos fatores ambientais atuam como moduladores deste padrão migratório. Como um padrão geral, tem-se que cada uma das categorias de "inverno" e de "verão", os "sinais" que individualizam o "inverno" ('frio' e 'chuva' ou 'corre seco') e o "verão" ('calor' e 'água salgada', 'água doce’ ou 'água misturada') e que materializam o tempo nas principais forçantes hidrodinâmicas, geram um conjunto de efeitos comportamentais no pescado que, por sua vez, se reflete nas estratégias de pesca no uso de petrechos a cada uma das espécies alvo. O sinal "águas cheias" e "águas baixas" na pesca do linguado, por exemplo, impede o movimento migratório "lameirão"-“croa", o que requer diferentes petrechos de pesca para cada situação ('menjoada' e 'fisga', respectivamente) e formas de uso do mesmo petrecho (rede de 'menjoada' mais próximo ao 'lombo' da 'croa' ou do 'lameirão', respectivamente). E há várias outras situações descritas no item 4.4.2.

Outro padrão geral que depende de forçantes hidrodinâmicas associado ao padrão migratório é o posicionamento das redes ao correr (da corrente) e atravessado (na corrente). As espécies que realizam a migração "lameirão"-“croa" na direção das correntes têm suas redes colocadas "atravessado" e aqueles que realizam este movimento migratório independente das correntes têm suas redes colocadas "ao correr".

Vale ressaltar que o "camarão de saquinho" constitui uma exceção à pesca do recurso que migra do "lameirão" para a "croa", uma vez que a estratégia de captura é preferencialmente centrada sobre aquele que "qué viajá" ou o "viajado", ou seja, que vai realizar o movimento migratório entre baixo estuário ('nosso mar') e cabeceira ('lá pra cima') a partir das correntes de enchente e de vazante. Por isso, as tomadas de decisão adaptam a posição das redes na "beira de croa" em função das correntes de enchente e de vazante ('na feição'), semelhante ao posicionamento das redes das outras espécies que realizam a migração "lameirão"-“croa” em função das correntes.

Neste sentido, dentro dos limites temporais de um "cenário" construído, é na modulação do padrão de migração “croa"-“lameirão" feita pelas principais forçantes 
hidrodinâmicas (vento, chuvas e Lua) que se dá a construção do "quando", "como" e "onde" ir pescar com precisão e especificidade máxima no uso dos petrechos.

A construção do "quando", do "onde" e de "como" utilizar uma técnica de pesca, seja fixa ou móvel, em geral tem a uma função muito clara: aproveitar do movimento migratório do pescado, sobretudo, no caso da Coréia, a migração "lameirão"-“croa".

Há, porém, uma diferença entre as técnicas de pesca fixas e móveis. Nas técnicas de pesca fixas, a rede é fixada num determinado lugar na espera pela sucessão natural do movimento migratório ('Se o peixe vim até ela eu vô matá, agora se o peixe num vim eu num pego nada...' Sindo, 40 anos, pescador artesanal) para evitá-lo, enquanto nas móveis a captura é provocada por ação do pescador, ou seja, não é o “peixe que vem" mas "É eu que vô até o peixe e faço ele malhá", embora também se use do movimento migratório do pescado no processo de captura. Em qualquer uma das técnicas móveis: no lance, o movimento da tainha da "croa" para o "lameirão" é provocado por batidas na água; no "linguado de fisga", é o pescador que fisga o linguado; no "camarão de coca", é o pescador que provoca o ensacamento do camarão que está enterrado ou em "manta". Vale ressaltar que no "lance de tainha" o movimento migratório é provocado para evitá-lo com as redes e, portanto, associa uma característica de técnica fixa e uma da móvel. Já nestas três últimas, aproveita-se da permanência do pescado em uma das unidades espaciais fundamentais, "croa" ou "lameirão". Por isso, usa-se do movimento migratório "lameirão"-"croa" conhecido que fundamenta o saber onde procurar o pescado, "croa" ou "lameirão".

As diferenças entre as técnicas de pesca fixas e móveis também foi pontuada por Diegues (2004b). Segundo este autor, com os petrechos fixos se espera e com os móveis se persegue o "peixe". Na Coréia também há perseguição do peixe com redes fixas, uma vez que também há procura por melhores pesqueiros, como foi visto para a tainha ('ressulho', 'pulo' e 'mareta'), para o camarão ('pulo' provocado) e para o linguado ('cama de linguado' e 'risco n'água'). A diferença é sutil, mas importante: considera-se aqui que a diferença entre os petrechos de pesca fixos e móveis está numa fase posterior àquela apontada por Diegues (2004b), ou seja, na espera pelo pescado (petrecho fixo) e na ação para capturá-lo (petrecho móvel) subsequente à procura e descoberta dos pontos de abundância ('pesqueiros'). 
Observa-se, portanto, consoante a Charest (1981), que a reprodução de estratégias de pesca se originam de fatores naturais de um território de pesca. Segundo Allut (2000), estes fatores naturais, sob o ponto de vista meteorológico, são os ventos e o "estado do mar". Seixas e Berkes (2003) avaliaram que, para os pescadores em Santa Catarina, o comportamento migratório dos recursos pesqueiros associado aos ventos, marés, temperatura do ar e da água, etc., sustenta as tomadas de decisões de "quando", “onde" e "como" pescar. Para os pescadores da Bahia, segundo Cordell (1974), é a maré astronômica que coordena toda a atividade pesqueira. Na Coréia, sob o ponto de vista etnooceanográfico, a reprodução das estratégias de pesca depende da interface das principais forçantes estuarinas percebidas como o vento, as descargas fluviais (chuvas) e, secundariamente, a Lua, e dos padrões migratórios das espécies pescadas, sobretudo o "lameirão"-“croa", em território coreano ${ }^{221}$.

A modulação do padrão migratório "lameirão"-“croa" pelas forçantes hidrodinâmicas é diferente entre as "safras de verão" e as "de inverno". Enquanto que nas "safras de inverno" fatores como o "frio" e as "águas baixas" fazem com que os recursos, com exceção da tainha, sejam pescados no "lameirão", no "verão" invariavelmente os recursos são pescados "nas croa", com exceção da "tainha de lance". Em Marques (1991) e Souto (2004) também registram diferenças de hábitats onde são encontrados os recursos pesqueiros entre "inverno" e "verão".

Outros processos naturais que resultam da ação das principais forçantes estuarinas se refletem no desempenho e manejo das técnicas de pesca. No cenário de "ano de água salgada", a "ardentia" ou "fogo no mar", a Lua cheia e o "lixo ruim" constituem fatores naturais que abrem um hiato em qualquer uma das safras, "de verão" ou "de inverno". O "fogo no mar" permite que qualquer "peixe" veja as redes e, no caso do camarão, diminui a ação da luz "que chama o camarão", o que inaugura um "tempo ruim" para a pesca. Cunha (2007) também registrou que a "ardentia" no Paraná é um "clarão" que afugenta os peixes, segundo os pescadores. No entanto, na Coréia, quando a Lua cheia e a "ardentia" ocorrem ao mesmo tempo, esta última "se some" melhorando a pesca. Também para os pescadores de Santa Catarina é melhor colocar as redes em

\footnotetext{
${ }^{221}$ Vale ressaltar que as diferenças pontuadas entre Cordell (1983), Allut (2000) e este trabalho é que as forçantes estuarinas dos respectivos territórios de pesca pesquisados também são diferentes, o que têm certo peso na apropriação cognitiva do meio. Enquanto, por exemplo, no estuário de Valência de Cordell (1983) a maré astronômica é a principal forçante de mistura, no estuário da Lagoa dos Patos, que fica numa região de micromaré ver item 3.1, esta função é desempenhada principalmente pelos ventos e pela descarga fluvial.
} 
noites de Lua cheia quando há luminescência na Lagoa de Ibiraquera, segundo Seixas e Berkes (2003).

As "noites de Lua" em qualquer cenário de "ano de água salgada" também permitem que o "peixe" "veja" a rede. Porém, qualquer evento natural que diminua a claridade da Lua cheia "é milhór pra pesca", como a presença de nuvens ou vento que "tolde a água" ou, no caso da pesca do camarão, a Lua cheia é considerada "bom" quando é grande a sua biomassa. Para os pescadores do estuário de Valência (BA), segundo Cordell (1974), em noites de Lua cheia os peixes são capazes de visualizar as redes, enquanto nas outras noites eles ficam mais vulneráveis.

A presença de "lixos ruim" também atrapalha e até impedem a pesca na Coréia, com exceção da pesca do peixe-rei, só sendo possível retornar ao ritmo normal de pesca depois que o "lixo ruim" apodrecer. Aggio (2008) registra em Florianópolis (SC) que os "lixos" atrapalham na pesca, enquanto Adomilli (2002) aponta a existência de "lixos" que dificultam a pesca no Rio Grande do Sul. Barenho (2008) regista diversos tipos de "lixo" que, segundo os pescadores da Ilha dos Marinheiros, muitas vezes impedem a atividade pesqueira.

Já no cenário de "ano de água doce", para os recursos pescados em água doce, funda-se a possibilidade da pesca durante do dia $^{222}$ e a não ocorrência da pesca do "linguado de fisga" em qualquer um dos turnos, devido à "água toldada" não permitir que o pescador enchergue o pescado. Por isso, em "anos de água doce" a luminosidade da Lua cheia perde sua influência. O mesmo ocorre em cenário de "ano de água salgada" sob a ação de vento, sobretudo o nordeste. Para os pescadores do Paraná, segundo Cunha (2007), a água também pode ser clara ou escura de acordo a influência dos ventos sendo esta última a preferida para a pesca, já que o peixe malha mais facilmente. O mesmo foi observado por Gianpaolo (2002) junto a pescadores da Lagoa do Peixe (RS) e para os pescadores do Ceará, segundo Maranhão (1975) e Oliveira Júnior (2003).

No entanto, a interface entre as forçantes hidrodinâmicas e o comportamento dos pescados só se refletem em estratégias no manejo de técnicas de pesca porque a ordenação desta interface é feita mediante os mecanismos e a lógica de uso dos petrechos. No caso do camarão, a ordenação do meio mediada pela rede de "saquinho"

\footnotetext{
${ }^{222}$ A única exceção é a pesca de "tainha de lance" que ocorre em qualquer um dos cenários de anos durante no período noturno ou diurno.
} 
se dá em função das correntes de enchente e de vazante e dos ventos que as geram, enquanto que mediado pela coca as correntes não têm importância. Para a "tainha de menjoada" a "água toldada" durante o dia é sinal para o seu uso durante o dia e já na "tainha de lance" é indiferente à categorização da água em "toldada" e "clara". Para o linguado, ventos nordeste durante o dia funda a pesca de menjoada, enquanto para a fisga abole, etc. No mesmo sentido, Cunha e Rougeulle (1989) e Allut (2000) pontuam que a observância dos ciclos reprodutivos e migratórios das espécies e, segundo Oliveira Júnior (2003), das condições ambientais, é feita de acordo com as técnicas adaptativas específicas.

Há, ainda, a procura de alguns "sinais" como as "maretas", o "pulo" da tainha, o "ressulho" e a "cama de linguado" e a produção de outros, como o "pulo" do "camarão", que complementam o arcabouço de conhecimentos na escolha de qual "lameirão" ou "croa" colocar as redes, pois indicam pontos de abundância, para a instalação de "pesqueiros" característicos de cada petrecho.

Allut (2000) avalia que localizar espacial e temporalmente os lugares de pesca produtivos é tarefa complexa que depende de um processamento seletivo de dados associado a vários fatores, como o substrato de fundo, a temperatura, a profundidade, correntes e época do ano, em consonância aos que foram discutidos para a Coréia. Cordell (1983) complementa ao afirmar que a concentração de pescados em certas áreas depende das marés, assim como de outros ciclos naturais que necessitam de operações especializadas em termos de apropriação ambiental. $\mathrm{Na}$ Coréia, esta apropriação ambiental ocorre de duas formas: através do conhecimento das forçantes ambientais, como foi construído até aqui, e da posse de determinado ponto de pesca que se fundamenta e se articula ao conhecimento, que será discutido em 4.5.

Portanto, é a relação homem/ambiente, mediada pelas técnicas de pesca específicas de cada pescado, que fundamenta as tomadas de decisão para o pescador melhor se adaptar a dinâmica ambiental construída.

A seguir, a aplicação das bases descritas para as tomadas de decisão é ilustrada pelas safras de camarão, tainha e linguado. 


\subsubsection{Camarão}

Como foi visto em 4.4.1.4, ao contrário das outras pescarias ${ }^{223}$, a pesca do camarão "aqui pra dentro" ocorre todos os dias no período noturno, inclusive em dias que para a pesca de camarão "não tá bom" dando um ritmo intenso ao "verão". No entanto, há alguns momentos de fundação da pesca diurna e de suspensão da pesca do camarão em todos os turnos. Neste sentido, a atenção dos pescadores coreanos está mais presente nos "sinais de memória" que constróem a suspensão da pesca do camarão do que na confluência daqueles que constróem o "quando" sair para pescá-lo de coca (rede de arrasto manual móvel) ou de "saquinho" (rede de espera). Deve-se pontuar que, em qualquer um dos dois cenários de "verão" favoráveis à pesca do camarão, seja o cenário "ano de água misturada" ou "de água salgada", a construção das decisões e ações se dão, em geral, da mesma forma, com ressalvas que serão feitas em momento oportuno. Outra questão importante se refere aos "sinais", que constróem as tomadas de decisão, para o camarão pescado de saquinho e os de coca são diferentes entre si.

Foi visto também no 4.4.1.1.1 que, em qualquer um dos cenários favoráveis à safra de camarão do oceano, há a entrada contínua de larvas no estuário, o que possibilita a existência de várias coortes de tamanho de camarão. Para o "nosso mar", que é "criador do bixo", a existência de várias coortes é fundamento para a existência de "falhas" durante a safra e de diferentes padrões migratórios ao mesmo tempo. As "falhas" e os diferentes padrões migratórios, por sua vez, constituem as bases para as tomadas de decisões e ações na pesca do camarão.

Se a entrada das "casquinhas" funda um tempo de espera para que o camarão atinja um tamanho considerado bom para o início da safra, o aparecimento das "cascas" durante a safra funda um outro tempo de espera:

O camarão, ele tem muita falha na safra: tem uma época que muda a casca, ele se enterra, a pessoa pega a casca dele na rede. Aí quando sai a casca dele cê espera. (...). Ele sai ali do chão e começa a viajá já com outra casca. (...). Se tivé quantidade de casca de camarão pode esperá que ele vai se arrancá do chão e dá camarão graúdo. (Dino, 67 anos, pescador artesanal).

\footnotetext{
${ }^{223}$ A pesca do "siri de verão" ocorre como captura incidental do camarão e, portanto, acompanha o ritmo de pesca diária do camarão.
} 
A "casca" é a carapaça que o camarão troca durante a ecdise ("tem uma época que ele muda a casca...') e que funda a espera ('falhas') pelo "camarão graúdo", ou seja, o camarão que "começa a viajá já com a outra casca". Vale ressaltar, no entanto, que esta "falha" pode se dar em todo o "nosso mar" ou apenas em alguns pontos de pesca onde a "casca" se faz presente.

Seja a partir da "casquinha", como foi visto no item 4.4.1.1.1, ou da "casca"224, os "sinais" que fundam ou, no caso das "falhas", "re-fundam" a pesca de "saquinho" são os mesmos: o "camarão que qué viajá".

No caso do "saquinho", rede de espera para camarão, a pesca se (re)inicia com o camarão que "qué viajá":

\begin{abstract}
Agora quando ele vai embora, que ele já tá pra í embora, que ele tá pra viajá, não, aí sim, ele vai caminhá n'água. Aí tu espera a monção, quando a monção dá pra ele, que a água vaza, ele vem na vazante, aí ele vai embora na vazante. Ele sai daqui, ele vai embora pra cima. (...) não vai pro oceano, percura pra lagoa. (Sr. Meca, 68 anos, pescador-lavrador).
\end{abstract}

Este "sinal", o camarão que "qué viajá", "metido a vermelho", "camarão de saída" (do território coreano), é um camarão que vai realizar sua migração no sentido sul-norte no interior do estuário durante a safra de camarão, do "nosso mar" vai "lá pra cima" ("Ele sai daqui, ele vai embora pra cima'), sendo pego com as redes na "feição", ou seja, com as redes posicionadas nas correntes de vazante ('...ele vai caminhá na água. [...] quando a monção dá pra ele, que a água vaza, ele vem na vazante') (Tabela 1). Vale ressaltar que, a espera pelo término das "falhas" e muitas vezes pelo início da safra se dá com as redes na água, pois só se sabe que há "camarão de saída" a partir do momento em que "a gente testa", ou seja, coloca-se as redes no "mar" e na "feição" ("rede de teste').

Como o "nosso mar" é o "criadô do bixo", predominantemente é o "camarão de saída" que se pesca mais: "Aqui dá mais camarão é na vazante" (Evaldo, 36 anos, pescador artesanal). Portanto, na maior parte da safra as redes vão estar posicionadas "na vazante".

O camarão "já tá pra í embora", no entanto, não é suficiente para que ocorra sua migração no sentido sul-norte. É ainda necessário "chuliá" a "monção" para o

\footnotetext{
${ }^{224}$ Como existem várias coortes de camarão, é possível a co-existência de "casquinhas" e "cascas" no "nosso mar".
} 
camarão "caminhá n’água", ou seja, um outro "sinal” que indica a saída de camarão "lá pra cima" nas correntes de vazante: "É porque o camarão vai criando e vai embora pra cima, ele vai criando ele num pára aqui dentro, vai criando e vai-se embora. (...), o rebojo leva ele pra cima" (Sr. Dino, 67 anos, pescador artesanal). O vento "rebojo" sinaliza a "saída" de camarão do território coreano ('camarão de saída'), pois, como foi visto no item 4.2, este vento gera correntes de vazante no "nosso mar" e "leva ele (o camarão) pra cima".

No cenário de "verão" ou "ano de água misturada", durante a safra, mas não no início, um outro "sinal" pode abolir as "falhas":

\section{Depois que ele sai daqui, ele pode voltá aqui só cum ponta de água doce. [...]. Ele pode voltá aqui pra nóis só se chuvê e juntá água doce lá, porque aí aperta o vento nordeste, né, e vem cum água doce aqui pra nóis. É o único jeito. (Sr. Meca, 68 anos, pescador-lavrador).}

As "pontas de água doce" associadas ao vento NE são "sinais" que marcam a entrada de camarão no "nosso mar" que "vem de cima". Com as correntes de vazante estuarina, e "enchente" no "nosso mar", provocadas pelas descargas fluviais ('Ele pode voltá aqui pra nóis só se chuvê e juntá água doce lá') e pela atuação do vento NE ('aí aperta o vento nordeste e vem água doce aqui'), o camarão migraria do norte para o sul do estuário, inclusive para as águas da Coréia ('Depois que ele sai daqui, ele pode voltá só cum ponta de água doce').

O camarão que "vem de cima" para o território coreano é o "camarão de entrada", "camarão que tá viajando" ou ainda "camarão viajado",225 que sinaliza uma necessidade de mudança na "feição das redes": "A noite passada o camarão que veio pra mim ali foi na enchente, na vazante não deu nada, e camarão bonito que veio de fora" (Milson, 25 anos, pescador artesanal). Com a chegada de "pontas de água doce", vento nordeste e as redes de "teste" indicando uma maior abundância de camarão na "enchente", as redes são posicionadas quase em sua totalidade na "enchente", em vez de na vazante como predominantemente ocorre, até que "sinais" (rede de teste e vento "rebojo") indiquem a "saída" de camarão. Consequentemente, um reposicionamento das redes para a vazante (Tabela 1).

\footnotetext{
${ }^{225}$ Os nomes do camarão são dados de acordo com o movimento migratório do camarão "lá pra fora" ou "aqui pra dentro" do território coreano. O camarão que "vai embora" do território coreano é chamado de "camarão de saída" ou de "camarão que qué viajá", enquanto que o camarão que "vem de cima" e entra no "nosso mar" é o "camarão de entrada", o "camarão viajado" ou o "camarão que tá viajando".
} 
Para os pescadores que pescam na "feição", ou seja, com as redes posicionadas "na enchente" e "na vazante", existe ainda um segundo tipo de "falha", quando ele só é pego na rede de "teste" de "boca pra fora" e "de boca pra terra" 226 , o que sinaliza que o camarão "não tá girando": "Camarão de boca pra terra e pra fora sempre é mais miudeiro. É um camarão que ele vem pra costa pra se criá e vai pra fora pra durmi, né, um camarão que não tá girando, pegando o caminho certo pra viajá" (Guega, 54 anos, pescador artesanal). O camarão "que não tá girando" é aquele que "não tá no ponto de viajá", um camarão "miúdo", ou seja, que ainda não atingiu um tamanho considerado bom, executando apenas o movimento migratório "lameirão"-“croa” (“É um camarão que ele vem pra costa pra se criá e vai pra fora durmi') e, por isso, pego somente por redes de "boca pra fora" e "boca pra costa", ou seja, redes colocadas "atravessado" ('Camarão de boca pra terra e pra fora sempre é mais miudeiro').

Todos têm a rede colocada "atravessado" para monitorar o movimento migratório do camarão ('rede de teste'), mas a pesca para comercialização com as redes nesta posição é condenada:

\begin{abstract}
O brabo é tu distroceis o contrário na andana, em veiz de sê assim atravessado no lameirão (na enchente e na vazante), que nem a nossa ali, é tu botais no correr da costa (atravessado). (...). E na feição o camarão que tu pega já é outro camarão deferente, né, ô. (...). Então aquele camarão o destino dele é viajá, né, o da feição. E esse de boca pra terra e pra fora é o camarão que ainda não tá no ponto de viajá, então ele fica viajando pra terra e pra fora. É aonde tá o mais miúdo. E o camarão de boca pra terra e pra fora (...) inté que dá mais. Tem épocas que esse daí que dá o dobro! (Guega, 54 anos, pescador artesanal).
\end{abstract}

Ainda que em maior quantidade de camarão seja pescada, a pesca com rede "atravessado" fere o código de ética coletivo de pesca ('O brabo é tu distroceis o contrário na andana, [...], é tu botais no correr da costa') ainda que maior quantidade de camarão seja pescada ('Tem épocas que esse daí que dá o dobro!'), enquanto a utilização das redes "na feição" é estimulada ('E na feição o camarão que tu pega já é outro camarão deferente'). Deve-se pontuar, no entanto, que mesmo assim há pescadores que praticam sistematicamente a pesca com a rede "atravessado" dependendo de onde a "rede teste" indicar maior abundância de camarão.

\footnotetext{
${ }^{226}$ Neste caso, a rede de "teste" é colocada de "boca pra fora" e de "boca pra terra" para monitorar o movimento migratório do "camarão miúdo". A rede de "boca pra fora" é quando se posiciona a rede em direção ao "mar", enquanto, a de "boca pra terra", é colocada com a abertura em direção à costa da Ilha dos Marinheiros.
} 
Como existem várias coortes de camarão ocorre o "camarão de saída", "de entrada" e o "miudinho" todos os dias, ainda que, dependendo da "monção de tempo", mais uns do que outros. Portanto, entre o "camarão de saída" e o "de entrada" não precisa ocorrer as "falhas", um e outro podem se suceder e até ao ocorrer ao mesmo tempo, o que, na verdade, ocorre com maior frequência do que entrecortados por "falhas". Neste sentido, vale ressaltar que as "falhas" podem demorar mais para alguns pescadores do que para outros, assim como para alguns podem nem ocorrer, dependendo da posição em que as redes se encontram ${ }^{227}$.

Neste sentido, as redes de "saquinho" são posicionadas de acordo com os "sinais de memória" gerados pelo conhecimento ecológico tradicional do padrão migratório do camarão:

O camarão casualmente é o que dá mais as veiz atravessado. Ele dá de tudo quanto é jeito, mas tem quadra que ele dá na água, dá atravessado... É conforme, conforme as veiz nóis tamo pescando, tamo pescando embocado na água, na correnteza e na beira da croa e ele não tá, tá dando de lado pra correnteza (atravessado). Porque ele não qué caminhá, ele tá parado. Ele só caminha pra cima da croa e pra í ao fundo. Agora quando ele vai embora, que ele já tá pra í embora, que ele tá pra viajá, não, aí sim, ele vai caminhá n’água. (Sr. Meca, 68 anos, pescador-lavrador).

A partir destes sinais, se constrói não apenas o "quando" ("quando ele vai embora (...), ele caminha n'água'; 'ele não qué caminha, ele tá parado'), mas o “como" e "onde" pescar: na feição ("tamo pescando embocado na água, na correnteza e na beira de croa...') ou "atravessado” ('...ele tá dando de lado pra correnteza. Porque ele não qué caminhá, ele tá parado. Ele só caminha pra cima da croa e pra í ao fundo'). Em ambos os casos, as redes são colocadas na "beira de croa". A relação de causa e efeito entre o padrão migratório do camarão e o posicionamento das redes que agrega o "quando", "onde" e "como" está materializada nos "sinais de memória" "camarão de saída", "camarão de entrada" e "camarão que não tá girando" (ou "não qué caminhá, ele tá parado') que determina o posicionamento das redes "na vazante", "na enchente" e "atravessado", respectivamente, "na beira de croa".

\footnotetext{
${ }^{227} \mathrm{O}$ mesmo vale para o início da safra: alguns podem ter o início da safra mais tardio do que outros.
} 
No caso da $\operatorname{coca}^{228}$, a abolição do tempo de espera pode ocorrer a partir de dois sinais, independentes entre si, que, além de construirem o "quando", constróem também o 'onde':

No junco do Neves o camarão se enterrô, mas tu pisava no chão assim era a mesma coisa que pisá em cima de toquinho, de toco de pau enterrado. (...). Quando nóis... anoiteceu, nóis saímo na procura: passa remo pra lá, passa pra cá, pra vê se pulava algum ou não... Nenhum, mai nenhum! Sabe o que que é nenhum? (Guega, 54 anos, pescador artesanal).

Antão, o camarão vinha em manta e aquele mangote de camarão se trabalhava de cima dele: tinhas que dá de remo, tocá e puxá e tocá pra puxada de novo. Aquilo num era uma noite, era sempre, sempre. (Sr. Meca, 68 anos, pescador-lavrador).

O camarão "graúdo" enterrado no chão ("toco'), o "mangote"229 de camarão e o camarão que "pula" quando se "passa o remo",230 são "sinais" que indicam "onde" pescar com a rede de coca (Tabela 1).

No pesca de coca, o "toco" e o camarão que "pula" quando se "passa o remo" fundam uma forma diferente de pesca do que quando o "sinal" é "mangote":

Eu tive pescando aí pra fora, aquele ano que eu tive aí fora pescando, (...), isso no tempo da coca... (...). Mas os camarão iam sempre pra lá, coisa que a gente vai buscá corrida: vai sempre, a gente larga lá na frente do mangote e puxa pra trás. Quando passa pelo mangote, pega o caíco a remo, ou a motore, e vai buscá lá na ponta de novo, ele vai costa afora. Ele em vez de vim de arriada, ele tava subindo pra cima. (Guega, 54 anos, pescador artesanal).

Há uns quinze anos atrás, tinha uns camarão ali pra frente do Polaco, (...), e o meu cunhado tinha dado um arrastão de setenta quilo de camarão de rede de coca, ele e o Dino. (...). Aí eu convidei o Guaraci e fomo lá, fomo lá direto a eles lá. Quando cheguemo lá perto deles lá, o chão tava fofinho era só camarão que tinha. Demos um arrastão de setenta-oitenta kilo de camarão. (Sr. Zezinho, 60 anos, pescador-lavrador).

Como pode ser visto na fala do Guega, o "sinal" "mangote" funda a pesca "corrida" de coca ('a gente larga lá na frente do mangote e puxa pra trás. [...], vai buscá lá na ponta de novo'), enquanto na fala do Sr. Zezinho o "sinal" "toco" ('o chão fofinho era só camarão que tinha') funda a pesca de arrasto ('arrastão').

\footnotetext{
${ }^{228}$ Não foi discutido "sinais" que "estabelecem prazos" para a coca porque as redes-teste utilizadas para monitarar a safra de camarão são as de "saquinho".

229 "mangote" e"manta" é uma terminologia local usada para o coletivo de camarão. "Manta" também é usado para o coletivo de qualquer outro pescado.

${ }^{230}$ Vale ressaltar que o camarão que "pula" quando se "passa o remo" é um "sinal de memória" produzido por ação humana. Através do "sinal de memória", há uma apropriação de uma resposta da natureza, no caso do camarão, a um estímulo humano na construção do "onde" pescar imbuído de temporalidade.
} 
Vale ressaltar que tanto o "camarão graúdo" quanto o "camarão emangotado" é "camarão de entrada" e/ou "de saída" ficando a pesca de coca sujeita aos eventos que sinalizam a "entrada" ('pontas de água doce' e vento NE em 'anos de água misturada') e a "saída de camarão" (vento 'rebojo'). Deve-se pontuar, no entanto, que é frequente alguns pescadores não esperarem que o camarão enterrado atinja o tamanho de "toco".

Para a coca, os "sinais" que indicam a "entrada" e a "saída de camarão" tem implicações completamente diferentes do que a pesca de "saquinho". Enquanto no saquinho os ventos indicam a posição da rede ('como'), na coca os ventos são "sinais" que constróem o "quando" pescar, uma vez que indicam o turno em que se deve pescar:

Tem que tê uma araginha de vento pra mexê cum a água também. De qualqué lado. É, o ventinho nordeste é o milhór, o vento nordeste é o milhór vento que tem, né. (...). É, porque o mar muito calminho demais, num tendo nenhum vento, num é bom não. É que tolda um pouquinho a água, né, e o camarão levanta mais até pra vim comê mesmo, né. (Sr. Rui, 60 anos, pescador artesanal).

Pra pescá camarão de dia a água tem que tá suja, toldada, nordeste em cima, é cum nordeste, e tem que sê de coca senão tu num consegue nenhum. (Sindo, 40 anos, pescador artesanal).

O vento "nordeste" funda dois momentos propícios para a pesca de coca ('como'): durante o dia ('quando') e durante a noite ('quando') porque "tolda a água". No entanto, para a pesca de coca a noite o vento pode ser "de qualqué lado", mas o “nordeste é milhór", enquanto durante o dia "é cum nordeste" (Tabela 1). Este "sinal", porém, traz ainda um outro significado: "Se puxá nordeste pode í de dia de coca que mata. E quando dá de dia é difícil dá de noite cum a coca" (Evaldo, 36 anos, pescador artesanal). O "sinal" que funda a pesca do camarão durante o dia, se "tivé (boa) quantidade de camarão", abole a pesca do "camarão de coca" à noite.

Além dos tempos de espera fundados pelas "casquinhas" e pelas "cascas" e sua abolição, outros "sinais" contribuem na construção do "quando" pescar na medida em que criam outros períodos de espera para qualquer um dos petrechos de pesca. Um deles é o prenúncio de "mal tempo", o "arco de vento"231.

Arco de vento é do rebojo. (...). O tempo tem que tá ruim, né. Eu fico no mar. (...). Ah, mas é de se apavora, né. Ah não, quando eu vejo que o tempo tá em cima mesmo eu nem me mexo, fico no mesmo lugar ali ou senão soco na beira da macega e deu, né. (...). Enquanto ele veio eu entrei dentro do valo. Aaaahhhh, dormi que parecia um buneco. (Risos). Pro rebojo, pro rebojo que

${ }^{231} \mathrm{O}$ "arco de vento" provoca a suspensão de todas as pescas na Coréia. 
é perigoso. Pra nóis perigoso é o rebojo. (Gordo, 39 anos, pescador artesanal).

O "arco de vento" é um arco de nuvens que se forma no horizonte antes da chegada de uma tempestade da direção do vento "rebojo". Com o "arco de vento", abrese três possibilidades de "mal tempo" para a pesca: "Ou vai dá chuva ou trovoada ou vento".

Um marco temporal datado, mas não fixo, que suspende a pesca do camarão é a semana santa, devido às histórias recentes de pesca de "camarão cum sangue", sobretudo na sexta-feira da paixão:

É, várias gente já matô, né, o Moises já matô, eu também já matei, já matei, de vertê sangue dele. (...). E várias pessoa já pegaram camarão na semana santa com sangue. (...) mas é só na semana santa que acontece. (...). Mas não é muito assim... todo ele, aparece um aqui, outro lá adiante. Mas não é todo o camarão, é um punhado, é apenas um punhado, né, ô, não é grande fartura. É um punhado que aparece no meio dos outro... 2-3 camarão. Eu num pesco na semana santa. (...). É, porque é um dia milagroso, né, ô. Que acredite quem quisé acreditá, mas o milagre existe e aprendi isso, né, ô. (Guega, 54 anos, pescador artesanal).

No entanto, foi observado em campo que, em "anos de água salgada", que a pesca de camarão se funda, mas "não tá dando nada", os pescadores saem para pescar durante toda a semana, inclusive na sexta-feira santa: "eu num vô pra deboxe. Esse $\mathrm{ano}^{232}$ tá ruim aí a pescaria, tô indo porque eu tô precisando" (Moisés, 45 anos, pescador artesanal). Por outro lado, foram observados pescadores que foram ao mar apenas para cuidar de suas redes das suas "andanas", sem usá-las ${ }^{233}$.

Um outro "sinal" que funda um tempo "ruim" para a pesca de camarão, mas não suspende a sua pesca, é a "noite de Lua":

Pra pegá bastante cum aquela rede, cum a coca, dependia da época, né, noite bem escura, toda ela escura. Que a noite de luar é negativo, não presta. Tem que sê uma noite toda escura. (Sr. Rui, 60 anos, pescador artesanal).

Pra nóis aqui, muitos dize, eu num sei, as veiz dá as veiz não: 'a Lua cheia é a mais ruim pra camarão de saquinho'. Que a noite fica um dia as veiz, né, então a luz num tem força de chamá o camarão. Fica a noite clarinha, o liquinho ou a bateria, que nóis tamo usando agora, num tem como chamá o camarão. (Evaldo, 36 anos, pescador artesanal).

\footnotetext{
${ }^{232}$ O "ano" que se refere o Moisés é o ano de 2007, ano do trabalho de campo desta dissertação, que foi "ano de água salgada".

${ }^{233}$ As redes de camarão ficam quase que permanentemente nas "andanas" durante toda a safra de camarão, saindo só para reparos. Como será visto em 4.5, a permanência das redes de camarão em um local é importante para marcar território.
} 
Como a principal estratégia de pesca, tanto na coca quanto no saquinho, é o uso da luz "pra chamá o camarão", a Lua cheia acaba maquiando a atração luminosa, o que atrapalharia a pesca (Tabela 1). No entanto, há uma controvérsia instalada no interior da comunidade que também está presente na fala do Evaldo: “eu num sei: as veiz dá as veiz não" camarão em "noite de Lua"234. Segundo alguns pescadores, a Lua cheia também pode sinalizar um bom período de pesca: "Quando tem camarão ele dá cum Lua, mas quando não tem é melhor sem Lua" (Adão, 56 anos, pescador-lavrador). Neste sentido, a ação da Lua cheia dependeria da abundância de camarão: se "tem camarão" a Lua cheia é um "sinal" que traz possibilidades de "boa mareada" e se "não tem camarão", a Lua cheia funda um período de escassez que só melhora com a sua abolição. Existe ainda uma outra possibilidade do "sinal" "noite de Lua" perder seu sentido negativo: “Também quando tá uma noite toda de luar mais tá encoberto, assim um tempo que teja se estragando pra chuva, né, então tapa a Lua... também já é outro lado, já dá camarão. Num pode tê é claridade, né” (Rui, 60 anos, pescador artesanal). Portanto, com a "noite de Lua" nublada a luminosidade da Lua cheia, que atrapalharia a atuação da luz artificial "pra chamá" o camarão, perde sua força e, consequentemente, seu status de "ruim" para a pesca de camarão.

No cenário do "verão de água salgada", pode ocorrer a diminuição da intensidade do esforço de pesca para o camarão quando a "água corre muito tempo salgada"235. Neste caso, funda-se um tempo de latência para a formação, ou não, de dois "sinais": "lixos" e a "água salgada demais". O "lixo-gosma" fecha as malhas das redes de camarão ('O gosma pega na malha da rede e só fecha, fecha e fecha a malha e num sai'), o que os obriga a tirar as redes para limpá-las ficando com menos redes no mar e, por vezes, até alguns dias sem pescar. Os outros "lixos"236 obrigam que os pescadores coloquem as redes de saquinho "pendendo":

\begin{abstract}
Mas o que manda mesmo é a correnteza, a feição da água. Tu tens que esperá a água deferente, tens que colocá a andana de frente à correnteza. Só dá um esquema ali com duas rede, né, pra não pegá muita sujeira. Fica uma meio pendendo prum lado e outra meio pendendo pro outro, num fica bem na cara dela (da correnteza). (Guega, 54 anos, pescador artesanal).
\end{abstract}

\footnotetext{
234 "Lua" = Lua cheia; "noite de Lua" = noite de Lua cheia; "sem Lua" = todas as Luas com exceção da Lua cheia.

${ }^{235}$ A "água corre muito tempo salgada" quando "corre inverno e verão salgada".

${ }^{236} \mathrm{O}$ que os coreanos chamam genericamente de "lixo" são pedaços de macrófitas aquáticas que aparecem boiando na água ou rolando no fundo das águas do Saco do Arraial e que eles genericamente categorizam como "lixo ruim". Dentre os "lixos" que compõem essa categoria genérica está o "lixo-fita", o "lixo-lã" e o "lixo-gosma".
} 
A rede de saquinho fica "pendendo" quando não é colocada completamente embocada na correnteza evitando, assim, os "lixos". No entanto, qualquer erro na colocação das redes, o que não é raro, principalmente pelos pescadores mais novos, resulta em dias sem pesca, devido ao tempo necessário para se limpar as redes ${ }^{237}$.

Já a "água salgada demais", "re-salgada" ou "muito salgada” é um "sinal” que, sucedido e associado a outro "sinal", o "fogo no mar", constrói um cenário de "verão de água salgada" para as tomada de decisões em que a saída para a pesca do camarão é menos frequente: "Água muito, muito salgada também é ruim. (...). Mexe a rede, né, e faz um fogo na rede, o peixe num malha. A 'água-viva' até pra camarão é muito ruim”. (Evaldo, 36 anos, pescador artesanal). Em casos em que dias sucessivos há o "fogo no mar" e o "num dá nada" de camarão é generalizado, foram observadas pescarias serem suspensas alguns dias até que notícias de melhora na captura e/ou "pontas de água doce" cheguem.

O "fogo no mar" pode ocorrer em qualquer época do "ano" em que "a água corra sempre salgada", "inverno" ou "verão". No caso dos "lixos", diferente do "fogo no mar", tem um período do "ano" em torno do qual ele aparece em território coreano, entre o "verão" e o "inverno":

Esse ano o lixo-fita deu no finalzinho do verão, mas tem anos que ele vem mais cedo, depende do clima, né: água salgada... (Delso, 40 anos, pescador artesanal).

Já esse gosma aí tá dando direto no chão. É, cum água salgada e cum o calor. (...). Esse ano (2007) ele apareceu mais no finalzinho, mas na Lagoa tinha desde cedo. Veio vindo de lá mesmo essa porcaria. (Sindo, 40 anos, pescador artesanal).

Portanto, o período de ocorrência dos "lixos" está no entorno do "final do verão" e início do "inverno", dependendo que a "monção de tempo" seja de algum tempo de "água salgada".

O fim do "tempo" em que a pesca do camarão se torna menos intensa, tanto pelo "fogo no mar" quanto pelos "lixos", é marcado pela chegada de "ponta de água doce"238. Este "sinal", porém, tem efeitos temporais diferentes nos dois casos: enquanto

\footnotetext{
${ }^{237}$ Em casos mais graves, em que a rede fica "atolada de lixo" ('perdida em lixo' ou 'chapada no lixo'), chega-se a manter as redes enterradas no solo por até 20 dias.

${ }^{238}$ A chegada de algumas "pontas de água doce" não transforma o cenário de verão de "água salgada" em de "água doce". Vale lembrar que "salgado" e "doce" são categorias criadas a partir de uma percepção
} 
no caso do "fogo do mar" há uma abolição imediata da suspensão da pesca do camarão, no dos "lixos" há um "chuliá" 239 pelo seu apodrecimento que não acontece de imediato: "O lixo-fita vai indo que ele se termina, (...). Mai demora, ele encosta nas macega e apodrece" (Delso, 40 anos, pescador artesanal).

Vários outros "sinais" de abolição do enfraquecimento da pesca do camarão devido os "lixos" podem ocorrer antes, durante ou depois da ocorrência da "ponta de água doce "240, os ventos geradores do regime de vazante, consequentemente "águas baixas", e o Sol:

O sol que faz esse lixo apodrecê. Ele encosta nas macega cum o vento, tendo água baixa, e ele fica. Aí ele apodrece todinho, (...). A água doce também ajuda a apodrecê, é que esse lixo-fita aí é da água salgada mesmo. (Delso, 40 anos, pescador artesanal).

Cum um saragassão e uma água doce, limpa o lixo todinho. Pra tirá aqui de dentro tem que sê noroestão. (Sindo, 40 anos, pescador artesanal).

Os "ventos de baixo" e os regimes de vazante têm a função de "encostar" o "lixo", que, assim, fica sob a ação do Sol, e de retirá-lo do território coreano pelos regimes de vazante, enquanto as "pontas de água doce" e o Sol agem de forma a "apodrecer" o "lixo".

Ainda que o pesqueiro de "camarão de saquinho", a "andana", seja fixa e registrada no IBAMA, como será visto em 4.5 , foi observado que, na prática, a troca de "andanas" é frequente pelos pescadores. Dois "sinais de memória" geram grande parte destas mudanças de andana, as "falhas" no seu pesqueiro ('cascas' e o 'camarão que não tá girando'), como foi descrito anteriormente, e o "represo":

\begin{abstract}
Agora, tem época que ele tá bem na costa aqui, no seco e a água do mar tá alta sim. Mas a gente sabe que o oceano anda represado. Mas leva tempos, cara: leva dez, quinze, vinte dias até um mêis. Depois normaliza. Aí pra pescá camarão é milhór até na beira das costa, tem mais água, né. Já dentro do fundo tá mais ruim, o camarãozinho vai pro baixo. Quem tem uma andana muito boa pra isso é o Dino. (...). Que andaninha boa, cara: ele vai, vai, vai, roda um mêis-dois num faz nada, cara, mais quando o cara chega aí pra abrilfim de março pega uma carga. O camarão costeia e ele mata. (Sindo, 40 anos, pescador artesanal).
\end{abstract}

relativa ao "salgado" e "doce" no contexto do "verão" e não do "inverno". Ademais, a chegada de "pontas de água doce" num contexto de "água salgada demais" gera a categoria "água salgada".

239 "chuliá" = espera com atenção.

240 As "pontas de água doce" não ocorrem necessariamente uma vez durante um certo período. A sua chegada no "nosso mar" pode ser frequente e até definitiva. 
Os "represos" que ocorrem a partir de março fundam um "tempo de águas cheias" onde o camarão "costeia" e os pescadores passam a colocar suas redes na "beira da costa" e não mais na "beira de croa", no caso do saquinho. Já no caso da coca, os arrastos passam a ocorrer mais frequentemente em "cima das croa": "Aí dependendo a água, né: quando a água tava muito baixa tinha que í mais pro fundo, quando a água tava cheia a gente procurava mais o baixo das croa" (Sr. Rui, 60 anos, pescador artesanal).

Em ambos os casos de troca de "andana", a escolha de outra é feita mediante a adoção de duas estratégias descritas para a coca: "Tá sentindo esses toco aí que tu tá pisando? Isso aí é camarão. Vô botá as rede aqui mesmo" (Amarildo, 40 anos, pescador artesanal) "Eu coloquei a rede lá porque tinha camarão lá. (...). Tu via, né, tu riscava o remo e ele pulava. (Sindo, 40 anos, pescador artesanal). Também para a escolha de outras andanas, o monitoramento do camarão enterrado através do tato ('toco') e de "passá o remo" também é utilizado (Tabela 1).

Os "represos" representam um marco temporal de extrema importância para a pesca do camarão. Toda a movimentação observada nas trocas de "andana" durante todo o mês de março, na verdade, é um ritmo que antecipa a saída dos pescadores coreanos para a pesca do camarão "ali fora", "ali no Mosquito", no "camarão de arriada". A intensa movimentação "aqui pra dentro" precede o ritmo frenético na pesca "ali fora". Não é por acaso que vários "sinais de memória" de "fim de safra" começam a aparecer a partir de março:

> Camarão "sete-barbas" (Xiphopenaeus Kroyeri) => "Esse sete-barba só aparecia misturado com esse nosso, em fim de safra. (...). Aparecia no nosso mare aqui, é, inda hoje apareceu um ou dois. (...). Mas é agora, agora nóis estamo entrando em fim de safra, né, ô, agora mês de março, entra mês de abril, mês de maio... já começa o final. As veiz não vai nem a mêis de maio, né, ô. (...). Aí a turma já começa a guardá as rede..." (Guega, 54 anos, pescador artesanal).

“Camarão safrinha" (Farfantepenaeus paulensis) => "Aquele dava muito, quando ele dava de arriada... (...). Era o nome que o pescadô botava, só que ele era vermelhinho que nem esse camarão de fora, esse grandão, mas ele era um camarão mediozinho. Era pouco tempo que ele dava, né, mas quando pegava ele, matava muito. Era quase fim de safra que ele dava" (Amarildo, 40 anos, pescador artesanal). 
Aranhola (sp?): “Também só aparece no fim do camarão agora. (...). Quando cumeçá pro fim mesmo, lá pro dia quinze de maio ou talvez até mais, cumeça a aparecê... nas rede. Tu pega duas-três. Também é sempre fim de safra que aparece. Início, meio, nunca ninguém pega" (Evaldo, 36 anos, pescador artesanal).

$>$ Maricá (Mimosa bimucronata) => “o marica já tá florescendo (17 de fevereiro). O maricá muda a temperatura: quando o maricá começa florescendo já num faz mais calor como fez antes. Eu via sempre os velhos dizê isso, né, desde eu criança, guri, eu escutava eles falare isso. Eles enchergavo uma flor no maricá, eles dizia assim: 'Ó, o maricá florindo. Pode contá que num faz calor já como fez'” (Sr. Rui, 60 anos, pescador artesanal).

Todos estes "sinais",241, sejam do "mar" como da terra, estão associados com outros "sinais" de suma importância na desconstrução da safra de camarão, e portanto, do "verão", e na construção do "inverno": o "frio", o "camarão de arriada" e os meses do outono. Também a sucessão destes "sinais", apesar de nem todos os pescadores acreditarem em todos eles, vai desconstruindo o "verão" e prenunciando o "inverno". O aparecimento de qualquer um deles não implica no fim imediato da safra de camarão e do "inverno", mas o início do fim que é gradual na mesma medida da chegada do "frio" ('agora nóis tamo entrando em fim de safra, agora mês de março, entra mês de abril, mês de maio... já começa o final'), das sucessivas "arriadas de camarão" das minguantes de abril, maio e, se houver, junho e da passagem dos meses do outono. É a latência do "fim de safra".

O "camarão de cola azul" 242 , por exemplo, também é um destes "sinais" de "fim de safra" e teve o seu aparecimento registrado no caderno de campo a partir do mês de março. Segundo histórias locais este camarão "entra do oceano" para buscar o camarão que se pesca dentro do estuário. Primeiro ele vai "lá pra Lagoa” buscar o "camarão de arriada":

Nóis seguia pescando camarão desse nosso aqui e entrava (do oceano) o que eles chamavam rabo azul, não é. O rabo azul era um camarão de palmo, mais ou menos um palmo. Rabo azul era o nome dele. O rabo dele era azul, ele abre o leque, né, e aquele leque dele era azul, era azul mesmo. (...) Antão ele

\footnotetext{
${ }^{241}$ Quando o "fim da safra de camarão" é antecipada pelas chuvas, qualquer um destes sinais perdem sua força no prenúncio do "inverno", já que o término da safra de camarão é o próprio anúncio do inverno.

${ }^{242}$ Segundo Seixas e Berkes (2003), na Lagoa de Ibiraquera (SC), há duas etnoespécies de camarão: o "camarão-rosa" e o "camarão de pata azul" que correspondem ao Farfantepenaeus brasiliensis e ao Farfantepenaeus paulensis da taxonomia científica, respectivamente.
} 
vinha, ele vinha pra buscá esse outro: ele ia até a lagoa nos mangote de camarão, nas manta de camarão. Ele ia até a lagoa pra buscá o outro camarão (o de arriada). Ele vinha do oceano pra buscá esse da lagoa. (...). Aí sim, quando esfriava o tempo o outro vinha arriá”. (Sr. Meca, 68 anos, pescadorlavrador).

É importante notar que a cena que o Sr. Meca descreve de captura do "camarão de cola azul", é "ali fora", quando ele "vem de arriada". Depois que o "camarão de cola azul" "arreia", ele leva o camarão do "nosso mar" embora:

Ele limpa o mar! Ah, limpa... esse tal camarão com rabo azul. Ele é vermelho, mais ele tem a cauda bem azul, né, ô. (...). Mas aquilo ali era de nuvidade prá aparecê aí e quando ele aparecia levava esse miúdo todinho, não ficava um pra remédio. (...). Eu sei que ele sumia e memo arrastando ele tu não encontrava o miúdo mais. Pudia tê um setor de camarão miúdo, mas se passasse um mangote daquele camarão... não, nenhum. (Guega, 54 anos, pescador artesanal).

O "camarão de cola azul vem buscá o de arriada" e por onde passa "leva esse miúdo todinho" construindo o "fim de safra" do camarão quando associado a ocorrência de um outro "sinal": o "camarão de arriada". A mesma lógica é aplicada ao "camarão safrinha" e ao "camarão sete-barbas".

Se os sinais "chuva" e/ou vento noroeste não sepultarem a "safra de camarão" e inaugurarem um "inverno", conforme visto no item 4.4.1.1.1, com a confluência de "sinais" em abril e maio, minguante e vento "rebojo", os pescadores coreanos saem "ali fora", na costa do "Mosquito"243 ('onde') para a pesca da "camarão de arriada" (Tabela 2). No entanto, se a atuação do vento "rebojo" é "sinal" para a saída, ao mesmo tempo, gera "sinal" para espera para a colocação do "saquinho":

O camarão vem junto cum a tainha as veiz, cara. Acompanha a tainha na bagunça do vento. Aí o cara perde, ele passô e o cara num vê. Não pega, o cara num bota rede, naquele dia num bota rede... temporal de vento! E ele vai embora! (...). Qualqué temporal acabô suas rede. (...). Calmô o vento rebojo já pode botá rede de camarão. Na calma, né, sempre na calma. (Moisés, 45 anos, pescador artesanal).

O tempo de espera fundado pelo vento "rebojo" é pela sua "calma” ('quando'), devido aos ventos "rebojo" intensos destruírem as redes fixas de pesca. Além disso, a "calma do rebojo" indica a posição ('como') para se colocar as redes:

${ }^{243}$ A "costa do Mosquito" é um "baixo" (ou baixio) do corpo principal estuarino. 
Quanto mais vento mais melhor, mais dá camarão. (...). Ele queria rebojo, Deus ajudô-le, deu o rebojo pra ele. (...). Que aí dá vazantão grande: a água subiu, subiu, subiu, que a gente chama, que é rebojo, né, levô, levô, levô... então a água lá em cima tá cheia. O camarão vem vindo. Aí quando calma rebojo ela desanda na vazante, né. Aí ela dá-le pra baixo! E é quando bota as rede na vazante e mata o camarão. (Moisés, 45 anos, pescador artesanal).

Com as intensas correntes de enchente provocadas pelo vento rebojo "lá fora" e o empilhamento de água no interior do estuário, a "calma do vento" produz intensas correntes de vazante, quando se coloca as redes de saquinho "na vazante". Neste sentido, pode-se dizer que a conjunção de "sinais" para a pesca do "camarão de arriada" constrói o "quando", “como" e "onde” pescar (Tabela 2).

Foi observado, porém, que alguns pescadores que não saíram "ali fora" para a pesca do "camarão de arriada" mantiveram a maior parte de suas redes na enchente após o vento "rebojo":

Pro camarão de arriada a gente pede o rebojo pro camarão ví e adepois pede a brisa. Vento! Quanto mais vento mais melhor, mais dá camarão.(...). E é quando dá essa brisa que o camarão entra aqui também pra nóis. Sem essas brisa é difícil entrá. (Moisés, 45 anos, pescador artesanal).

Não só lá fora, mas também "aqui pra dentro" o "rebojo", durante o "camarão de arriada", funda um tempo de espera por outro "sinal", o vento nordeste ('brisa'), que possibilita o "camarão de entrada" nas águas da Coréia na sua migração do estuário para o oceano. No entanto, o vento nordeste precisa gerar um regime de enchente no "nosso mar" para que "o camarão entra aqui": "Entra, cum força de água de enchente ele vem aqui. Antigamente, nóis matava muito desses camarão aqui, chegava a enchê os caíco cum esses camarão grande, de arriada, que vinha tocado de forças d'água de enchente" (Sr. Rui, 60 anos, pescador artesanal). O que só acontece, como foi visto no item 4.2, quando associado a "pontas de água doce": "O camarão pode voltá aqui pra nóis só se chuvê e juntá água doce lá porque aí aperta o vento nordeste, né, e vem cum água doce aqui pra nóis. É o único jeito" (Sr. Meca, 68 anos, pescador-lavrador) (Tabela 1). Neste sentido, só em "anos de água misturada" aqueles pescadores que não saíram para pescar "ali fora" ganham seu quinhão de "camarão de arriada".

Abolida a confluência de "sinais" que inauguraram o "camarão de arriada", sepulta-se a safra de camarão e o "ano de água salgada" ou "de água misturada", inaugura-se um "inverno". 


\begin{tabular}{|c|c|c|c|c|c|}
\hline $\begin{array}{c}\text { Etnocronologia } \\
\text { estuarina }\end{array}$ & \multicolumn{3}{|c|}{ Quando } & Como & Onde \\
\hline \multirow{4}{*}{$\begin{array}{l}\text { “ano de água } \\
\text { salgada }\end{array}$} & vento $\mathrm{NE}$ & \multicolumn{2}{|c|}{ dia ou noite } & $\begin{array}{l}\text { "arrasto de } \\
\text { coca" }\end{array}$ & $\begin{array}{c}\text { “croa" c/ } \\
\text { "toco" e/ou } \\
\text { “camarão que } \\
\text { pula" }\end{array}$ \\
\hline & & & & $\begin{array}{l}\text { "corrida" de } \\
\text { "coca" }\end{array}$ & $\begin{array}{c}\text { "lameirão" ou } \\
\text { "croa" c/ } \\
\text { "mangote" }\end{array}$ \\
\hline & $\begin{array}{l}\text { Qualquer } \\
\text { vento }\end{array}$ & \multicolumn{2}{|c|}{$\begin{array}{l}\text { "noite escura" ou noite } \\
\text { "nublada" }\end{array}$} & $\begin{array}{l}\text { "arrasto de } \\
\text { coca" }\end{array}$ & $\begin{array}{l}\text { "croa" c/ "toco" } \\
\text { e/ou "camarão } \\
\text { que pula" }\end{array}$ \\
\hline & \multirow{3}{*}{$\begin{array}{l}\text { vento } \\
\text { "rebojo" }\end{array}$} & $\begin{array}{l}\text { "camarão } \\
\text { que qué } \\
\text { viajá’" }\end{array}$ & \multirow{3}{*}{$\begin{array}{l}\text { "noite } \\
\text { escura" } \\
\text { ou noite } \\
\text { nublada }\end{array}$} & $\begin{array}{l}\text { "saquinho" } \\
\text { posicionada } \\
\text { na vazante }\end{array}$ & $\begin{array}{c}\text { "beira de croa" } \\
\text { de andana } \\
\text { registrada e/ou } \\
\text { c/ "toco" e } \\
\text { "camarão que } \\
\text { pula" }\end{array}$ \\
\hline \multirow{7}{*}{$\begin{array}{l}\text { "ano de água } \\
\text { misturada" }\end{array}$} & & \multirow{2}{*}{$\begin{array}{c}\text { "camarão } \\
\text { que costeia" }\end{array}$} & & $\begin{array}{c}\text { "saquinho de } \\
\text { boca pra } \\
\text { fora" }\end{array}$ & "beira da costa" \\
\hline & & & & $\begin{array}{l}\text { "corrida" ou } \\
\text { "arrasto de } \\
\text { coca" }\end{array}$ & $\begin{array}{l}\text { "em cima das } \\
\text { croa" ('baixo } \\
\text { das croa') }\end{array}$ \\
\hline & \multirow{3}{*}{$\begin{array}{l}\text { "ponta de } \\
\text { água } \\
\text { doce" }\end{array}$} & \multirow{3}{*}{$\begin{array}{l}\text { "camarão } \\
\text { viajado" e } \\
\text { "camarão } \\
\text { de arriada" }\end{array}$} & \multirow[t]{3}{*}{$\begin{array}{l}\text { dia ou } \\
\text { noite }\end{array}$} & $\begin{array}{l}\text { "saquinho na } \\
\text { enchente" }\end{array}$ & $\begin{array}{l}\text { "beira de croa" } \\
\text { de andana } \\
\text { registrada e/ou } \\
\text { c/ "toco" e } \\
\text { "camarão que } \\
\text { pula" }\end{array}$ \\
\hline & & & & $\begin{array}{l}\text { "arrasto de } \\
\text { coca" }\end{array}$ & $\begin{array}{l}\text { "croa" c/ "toco" } \\
\text { e/ou "camarão } \\
\text { que pula" }\end{array}$ \\
\hline & & & & "corrida"de & "lameirão" ou \\
\hline & & \multirow{2}{*}{\multicolumn{2}{|c|}{ dia ou noite }} & coca & "mangote" \\
\hline & vento $\mathrm{NE}$ & & & $\begin{array}{l}\text { "arrasto de } \\
\text { coca" }\end{array}$ & $\begin{array}{c}\text { "croa" c/ "toco" } \\
\text { e/ou "camarão } \\
\text { que pula" }\end{array}$ \\
\hline
\end{tabular}

Tabela 1: Tomada de decisão para a pesca de camarão "aqui dentro". 


\begin{tabular}{|c|c|c|c|c|c|c|}
\hline \multirow{2}{*}{$\begin{array}{c}\text { Etnocronologia } \\
\text { estuarina }\end{array}$} & \multicolumn{4}{|c|}{ Quando } & \multirow{2}{*}{ Como } & \multirow{2}{*}{ Onde } \\
\hline & sair & ali fora" & colocar & redes & & \\
\hline $\begin{array}{l}\text { “ano de água } \\
\text { salgada” ou } \\
\text { “de água } \\
\text { misturada }\end{array}$ & $\begin{array}{l}\text { vento } \\
\text { rebojo }\end{array}$ & $\begin{array}{c}\text { Lua } \\
\text { minguante } \\
\text { de abril, } \\
\text { maio e } \\
\text { junho }\end{array}$ & $\begin{array}{l}\text { "calma do } \\
\text { rebojo" }\end{array}$ & $\begin{array}{l}\text { "boca da } \\
\text { noite" }\end{array}$ & $\begin{array}{c}\text { "saquinho } \\
\text { na } \\
\text { vazante" }\end{array}$ & $\begin{array}{l}\text { "beira de } \\
\text { croa" na } \\
\text { "Ponta do } \\
\text { Mosquito" }\end{array}$ \\
\hline
\end{tabular}

Tabela 2: Tomada de decisão para a pesca de camarão "ali fora".

\subsubsection{Tainha de verão}

Como foi visto em 4.4.1.2.1 e 4.4.1.1.2, existem duas etnoespécies de tainha: a "de coresma" e a "de corrida". Na pesca da "tainha de coresma" são usadas as redes de menjoada (rede de emalhar de espera) e de lance (rede de cerco móvel) com malha variando de 40 a $45 \mathrm{~mm}$, enquanto na "tainha de corrida" pesca-se apenas de menjoada com malha de 45 a 50mm. No entanto, há uma tendência de diminuição da malha usada para a "tainha de coresma" tendo um número considerável de pescadores usando malha $35 \mathrm{~mm}$. Se o cenário for de "verão de água doce", a malha utilizada é ainda menor, de 30 a $35 \mathrm{~mm}$, semelhante ao que será visto para a "tainha de inverno" no item 4.4.2.3.

Os "sinais" que individualizam os cenários de "verão de água salgada" e "de água doce" para a pesca da "tainha de coresma", por si só, constróem algumas decisões e ações de "quando" e "como" pescar tainha. A "água salgada" sinaliza para a pesca de menjoada ('como') no turno da noite ('quando'), porque de dia o peixe encherga a rede: "Cum água clara a tainha de menjoada é de preferência de noite, de dia ela vê as rede..." (Sr. Zezinho, 60 anos, pescador-lavrador) (Tabela 3).

Há, no entanto, dois sinais que, na construção do "quando", possibilitam a inversão do turno de saída para o mar. Um deles é o vento: "Cum vento que tolde a água, a tainha dá de dia também. O nordeste é milhó, cum bastante vento, né” (Delso, 40 anos, pescador artesanal). Com o vento, sobretudo o NE, a "água salgada" fica turva ('toldada'), o que dificulta que o "peixe" enchergue a rede durante o dia. O outro é a Lua cheia que cria uma categoria de noite, "noite de Lua", que é um "sinal" para a suspensão da pesca de "tainha de menjoada" durante toda o período de Lua cheia, porque a tainha encherga a rede: “As veiz as noite escura são melhor, né. Depende também se tá... cum água salgada a noite de Lua, aí já é meia ruim, né porque clareia muito. Aí as noite escura são melhor" (Amarildo, 40 anos, pescador artesanal). A Lua 
cheia cria uma categoria de noite, a "noite de Lua", em que durante toda a sua vigência e recorrência a pesca da tainha de menjoada é suspensa. Ao término das "noites de Lua" e ao início do período das "noite escura", abole-se a suspensão da pesca da "tainha de menjoada" (Tabela 3).

Já para a pesca de "tainha de lance”, a “água salgada” é um "sinal” favorável em qualquer um dos turnos, dia ou noite:

\begin{abstract}
Na tainha nóis lanceava, assim, de verão na água clara. De dia ou de noite, tanto faz. (...). Quando a água tá bem clarinha que o peixe tá matreiro demais, ele vai malhá na última volta. Vai ficando aí ela se obriga, né. Como eu gostava dessa pescaria! Quando chegava na última voltinha o peixe cumeçava a malhá. (Sr. Rui, 60 anos, pescador artesanal).
\end{abstract}

Ainda que a tainha enxergue a rede dificultando sua captura ('o peixe tá matreiro demais'), o lance como técnica de pesca móvel "obriga" a tainha a "se atirá na rede" ('vai malhá na última volta') (Tabela 4).

No cenário do "verão de água salgada" pode haver suspensão ('quando') da pesca da tainha quando a "água corre muito tempo salgada" $" 244$. Neste caso, funda-se um tempo de latência para a geração, ou não, de dois "sinais" que independem entre si: "lixos" e a "água salgada demais". Os "lixos" impedem a pesca da tainha mesmo que ela já tenha iniciado, porque "embuxa as rede" 245 e as destrói: "O lixo-gosma é mais quando é ano de água cortada, né, água salgada. Aí dá, aí cria, né. (...). Aquele é danado, quando dá, bah, tu perde a rede de linguado. (...) a rede de linguado e a rede de tainha... É triste. (...). É horrível!” (Gordo, 39 anos, pescador artesanal) ${ }^{246}$.

Mesmo com o "sinal de memória" indicando suspensão da pesca da tainha, ainda tem alguns pescadores que vão ao mar pescar "tainha de lance" "chuliando" um hiato criado pela sucessão de dois sinais, um que funda ('água parada') e outro que extingue (a 'Lua de saída'):

Agora mesmo, nóis tava na tainha agora, tinha muito lixo e nóis num cunsiguia lanceá em certos lugá. Então quando corria água nóis tinha que vim embora: a Lua nascia, a água botava pra corrê e nóis tinha que vim embora. Num se cunsiguia lanceá por causa do lixo, que a rede enchia de lixo. Aí nóis viemo embora. (...). Tem que sê só cum água parada pra lanceá. Quando tava

\footnotetext{
244 A "água corre muito tempo salgada" quando "corre inverno e verão salgada", ou seja, quando o cenário é de "ano de água salgada".

245 "embuxá as rede" ou "chapá as rede" é o mesmo que encher as redes de "lixo".

${ }^{246}$ A única pesca que não é dificultada pela presença de lixo é a de peixe-rei: "Peixe-rei não, peixe-rei é uma rede baixinha, se tu baté o lixo sai" (Gordo, 39 anos, pescador artesanal).
} 
parada nóis pudia trabalhá, cum ela correndo num se lanceava mais. Ela fica perdida em lixo! (Sr. Dino, 67 anos, pescador artesanal).

A "água tá parada" é o "sinal” que funda e mantém o único momento de pesca de tainha de lance durante o "tempo de lixo" ("Tem que sê só cum água parada pra lanceá. Quando tava parada nóis pudia trabalhá...') e que dura até o aparecimento da "Lua de saída", pois é ela que inverte o sentido das correntes em "nosso mar", como foi visto no item 4.2, "botando a água pra corrê" ('Então quando corria água nóis tinha que vim embora: a Lua nascia, a água botava pra corrê e nóis tinha que vim embora. Num se cunsiguia lanceá por causa do lixo') (Tabela 4).

Já o "fogo no mar", constrói o outro cenário de tomada de decisões que impede a saída para a pesca da tainha:

Água muito, muito salgada também é ruim. Aí a tainha vê aquela água viva, né, aquele fogo na água, vê a rede num malha. (...). Uns chamam de ardentia, outros chamam de água viva. (...). Isso aí pra malhá o peixe é ruim, qualqué peixe: tanto faz linguado, tainha... Mexe a rede, né, e faz um fogo na rede, o peixe num malha. (Evaldo, 36 anos, pescador artesanal).

O "fogo no mar" pode ocorrer em qualquer época do "ano" em que "a água corra sempre salgada" e permite que a "tainha veja a rede", "inverno que corre seco" ou "verão de água salgada". Na pesca da "tainha de menjoada" o "fogo no mar" gera uma inversão das noites "boas" e "ruins", enquanto na pesca de lance cria uma "noite ruim":

Conforme a água também, né, vamo mai longe: num tem Lua, a água tá muito salgada, aí ela larga aquele fogo no mar. Então quando a Lua (cheia) nasce, aquilo desaparece e é quando ela malha. Num sei se tu já visse, aquela ardentia, aquele fogo na água? A tainha não malha. Aí a rede se mexe e aquele fogo passa na rede assim e a tainha não dá (...) nem de menjoada nem de lance. Mas depois que aquilo desaparece, a Lua alteia e aquele clarão. (Sr. Dino, 67 anos, pescador artesanal).

O "fogo no mar" transforma as "noites de Lua" em noites "boas" e as "noites escuras" em noites "ruins" para se pescar tainha de menjoada e de lance ("num tem Lua, a água tá muito salgada, aí larga aquele fogo no mar. [...]. A tainha não malha [...] nem de menjoada nem de lance'), porque o "a ardentia se some" com a "Lua de saída" ('Então quando a Lua nasce, aquilo desaparece e é quando ela malha'). O "se some" se deve à diminuição da visibilidade das redes pela tainha sob o efeito da "ardentia", já que a Lua cheia também iluminar o “mar”. Desta forma, não apenas a região no entorno da 
rede se ilumina em resposta à movimentação da rede, mas todo o "mar", devido à Lua cheia (Tabela 3 e 4).

No caso dos "lixos", diferente do "fogo no mar", tem um período do "ano" em torno do qual ele aparece em território coreano, como foi visto para o camarão no item 4.4.2.1. O período de ocorrência dos "lixos" está no entorno do final do "verão" e início do "inverno", dependendo que a "monção de tempo" seja de algum tempo de "água salgada".

O fim da suspensão da pesca da tainha, tanto no cenário construído pelo "fogo no mar" quanto pelos "lixos", é marcado pela chegada de "ponta de água doce", "ventos de baixo", "águas baixas" e Sol, assim como foi descrito para o camarão no item 4.4.2.1.

No cenário de "verão de água doce”, a "água doce” ('suja') é um sinal que funda a pesca da tainha de menjoada e de lance em qualquer um dos turnos ('quando'), dia ou noite: "Que nem a tainha, já vô dizê pra ti, (...), a tainha tu pega ela de dia ou de noite com água suja, meia misturada, doce, de menjoada, cum rede parada. Cum água suja o lance vem sê a mesma coisa: de dia e de noite" (Sindo, 40 anos, pescador artesanal) (Tabela 3 e 4).

No cenário de "verão de água doce" também pode haver a suspensão da pesca da tainha "se a água for muito doce" ${ }^{, 247}$ para qualquer uma das técnicas de pesca. Os intensos regimes de vazante, devido à alta descarga fluvial, que em território coreano é chamado de "enchente", inauguram um tempo de espera por três "sinais de memória", "ventos de cima", "represo" e "entrada de pontas de água salgada", um seguido do outro interdependentemente, que se engendram a partir do "sinal” "água muito doce" na construção do "quando" pescar:

\footnotetext{
Em noventa e oito (...) eu acho que nóis tava pescando era tainha. (...). Aí dava, quando vinha aquelas ponta de água salgada dava umas tainha. Quando dava esses vento de cima, quando represava, que dava uma água meio que cumeçava a salgá, o peixe, a tainha vinha. Aí depois aquela força d’água vinha e levava tudo de novo. Aí tinha que esperá de novo, então a gente esperava um monte de tempo aí sem pescá. A água quando corria pra cá (de enchente) o peixe vinha, quando dava o nordeste vinha aquela água doce e o peixe ia embora de novo. (Sr. Dino, 67 anos, pescador artesanal).
}

\footnotetext{
${ }^{247}$ Segundo a estrutura cognitiva dos pescadores da Coréia, a categoria "água muito doce" ocorre só "se tivé muito peso de água lá pra cima".
} 
Mesmo com "força de água lá pra cima", os "ventos de cima" fazem com que o "oceano encoste", gerando os "represos", que, por sua vez, favorece a "entrada de pontas de água salgada" e, com as "pontas de água”, a tainha ('Quando dava esses vento de cima, quando represava, que dava uma água meio que cumeçava a salgá, o peixe, a tainha vinha'). O extermínio deste hiato na suspensão da pesca ocorre "na calma do vento" ou quando "dá o nordeste" retornando os intensos regimes de "enchente" de água doce que "leva o peixe embora de novo" ("Quando dava o nordeste vinha aquela água doce e o peixe ia embora de novo'). A partir daí, um tempo de espera pelos “sinais de memória" é (re)criado ("Aí tinha que esperá de novo, então a gente esperava um monte de tempo aí sem pescá') (Tabela 3 e 4).

Já construído as tomadas de decisões de "quando" sair ao "mar" para se pescar "tainha de lance", durante a pesca, alguns "sinais" são apropriados na construção "onde" procurar tainha para o lance independente de qual o cenário de "verão", "de água salgada" ou "doce":

Tu vai de dia viajando tu encontra ela um remo de fundura aqui no nosso mar aqui, que é o máximo. Tu encontra ela no fundo no caso: tu lanceias, matas peixe. Anoiteceu tu não acha mais ela ali naquele lugá: ela vai pra cima das croa e tu vai achá ela lá. Ela procura a croa, ela vai durmí na croa. (Moisés, 45 anos, pescador artesanal).

Através do conhecimento ecológico tradicional da migração "croa"-"lameirão" da tainha durante o dia, na pesca de lance, procura-se a tainha no "lameirão" e de noite "em cima das croa". Porém, foi observada em campo a procura de tainha para o lance "em cima das croa" também durante o dia, porque "a tainha é um peixe que gira muito, tá sempre girando" (Sr. Dino, 67 anos, pescador artesanal) (Tabela 4).

Associado com o conhecimento do padrão migratório da tainha e mediado pela forma de utilização da técnica de pesca o Sol, a Lua cheia ('a Lua'), além da construção do "quando", e o vento indicam a direção em que a tainha "vai corrê" contribuindo na construção do "onde" e "como" lancear:

A gente lanceia a rede, tem tainha, e quando a Lua tá altinha ela malha só embaixo da Lua. A rede fica pra Lua de lance, né, a rede fica embaixo da Lua, ela malha todinha ali. É que ela caminha pro clarão da Lua e aí malha todinha. É o mesmo que o Sol, o peixe gosta de malhá por baixo do Sol também... de dia. Ele percura o clarão. (Dino, 67 anos, pescador artesanal). 
A tainha tu lanceias contra o vento, ela corre o vento, né, (...), ela vai corrê pro vento. (...). Ela vai pendê sempre a í pro fundo, o peixe tá no baixo ela vai corrê pro fundo. (Gordo, 36 anos, pescador artesanal).

Em qualquer um dos três "sinais" a tainha "vai corrê" na direção do vento ("ela vai corrê pro vento'), do Sol ('o peixe gosta de malhá por baixo do Sol...') e "da Lua" ('ela malha só embaixo da Lua') sendo que o lance começa a ser aberto na direção contrária a da migração da tainha ('A rede fica pra Lua...'; ‘tu lanceias contra o vento').

No entanto, as implicações são ainda mais profundas na construção do "onde" pescar quando estes "sinais" são tomados como referenciais em função da sua posição em relação a rota migratória da tainha entre "croa" e "lameirão":

\begin{abstract}
A Lua tava numa certa altura, dessas taquara mais ou menos assim (...). Me ressulhô uma tainha perto, no caíco, e eu disse pra ele: 'Emenda! Abre! Abre que nóis tamo no peixe!'. (...). Ela corre pra claridade da Lua. Então tu lanceia sempre, sempre a favor da claridade da Lua. Ela vai corrê direto à Lua. Ela tá num lugá baixo aqui... óia, isso aqui é uma croa, se tu vins de lá, lá na croa, num pode lanceá ela. Tem que percurá calmamente a passais por ela, e aí chegais no fundo, lanceá ela do fundo pro baixo. Ela vai dispará pro fundo... vai dispará pro fundo. Aqui nessas altura a croa fica na claridade da Lua, nem toda feição de mar, agora na feição do nosso mar ela fica. Ela fica na claridade da Lua. Então a Lua manda muito pra nóis. Tem um monte de lugá que num é como aqui, é diferente de um lugá pro outro. Nóis aqui memo, nóis nos guvernemo mais pela Lua... (Sr. Meca, 68 anos, pescadorlavrador).
\end{abstract}

O lance sempre ocorre do "fundo pro baixo", porque, devido o comportamento migratório da tainha, "ela vai dispará pro fundo". Como "a croa fica na claridade da Lua", quando "a Lua" está baixa ("A Lua tava numa certa altura, dessas taquara mais ou menos'), sua posição influencia na escolha entre as croas da Ilha da Torotama e da Ilha dos Marinheiros para se lancear tainha: na "Lua (cheia) de saída" há preferência pelas "croa" da costa da Ilha da Torotama, enquanto na "Lua (cheia) de entrada" há preferência pelas "croa" da costa da Ilha dos Marinheiros. O Sol é utilizado sob a mesma lógica para a construção do "onde" e "como" pescar que a Lua cheia, só que, obviamente, o Sol é um referencial para a pesca de durante o dia e a Lua para a de durante as "noites de Lua". O vento, apesar de regido sob a mesma lógica, merece suas próprias considerações: se for o "vento de cima" as "croa" da Ilha dos Marinheiros são preferidas, enquanto se for o "vento de baixo" as "croa" da Ilha da Torotama ganham preferência $^{248}$ (Tabela 4).

\footnotetext{
${ }^{248}$ Vale ressaltar que, entre os três, o vento é o "sinal" considerado mais importante, pois é o primeiro que se leva em consideração e é extensamente mais conhecido e citado em todas as entrevistas.
} 
Tanto durante o dia no "lameirão" quanto durante à noite "em cima das croa", há a procura por "sinais" que indiquem em qual croa ou lameirão ('onde') tem peixe: “Chega lá, vê ela ressulhá ou vê aquelas mareta... ela malha, mas quando tá pulando aí num malha nenhuma. Podes lanceá que num pega!” (Delso, 40 anos, pescador artesanal). O "ressulho", as "maretas"249 e o "pulo" são "sinais" que indicam "onde" tem peixe e "quando" pode lanceá-lo. Quando o pescador vê várias tainhas "ressulhando" em "cima da croa" ou no "lameirão" é "sinal" que pode "lanceá"-la que a captura ocorrerá com sucesso (Tabela 4). No entanto, quando a tainha está "pulando" é "sinal" que ela "num malha", portanto se "lanceá"-la a captura não ocorrerá com sucesso.

Quando a tainha está "pulando" um tempo de espera se funda pela sucessão de dois "sinais":

\begin{abstract}
Aí quando a Lua nasce ela se aquieta. Qualqué Lua. (...). Quando ela tá pulando nem adianta tu saí. Ah não! Difícil de matá. A não sê esperá a hora que ela se aquiete, a hora que ela se aquietá sim. Na boca da noite ela se aquieta, podes lanceá que tu mata, mesmo se a Lua num tive saído. Nas barra do dia também. (Delso, 40 anos, pescador artesanal).

Parece mentira: as veiz a tainha tá pulando, pula pra um lado e pra outro, esperava que a Lua nascesse ou entrasse e a tainha se acomodava. Tu num via mais nenhuma pulá! Aí tu lanceava e tu pegavas ela. (Sr. Dino, 67 anos, pescador artesanal).
\end{abstract}

O intervalo de tempo compreendido entre a "boca da noite" e a "Lua de saída" e entre as "barrinha do dia" ("Na boca da noite ela se aquieta [...]. Nas barra do dia também') e a "Lua de entrada" ('esperava que a Lua nascesse ou entrasse') são "sinais" sucessivos que constróem a latência máxima para o irrompimento do lance de tainha ('podes lanceá que tu mata'). Durante o intervalo compreendido entre o Sol e a Lua, o pescador coreano detém-se "chuliando" para que a tainha se "acomode" e, a partir daí, seja possível através de sua técnica de pesca ('rede de lance') capturar a tainha. Construído o "quando", “como" e "onde” lancear, irrompe-se o lance de tainha (Tabela 4).

A construção do lance de tainha é feito do "do fundo pro baixo" porque a migração da tainha do "baixo pro fundo" é provocada pelos pescadores ('O batedor anda sempre pela croa e o peixe sempre foge pra fora, pro lameirão. [...] aí o batedor vem batendo lá da croa e o peixe abrindo pra fora'). Se o lance ocorre durante o dia no

249 "Maretas" ou "água tremida" se refere à pequenas ondas formadas pela movimentação do cardume. 
lameirão, todos os referenciais para a tomada de decisão continuam sendo utilizados com exceção da Lua.

Na construção do "onde" para a tomada de decisões e ações na pesca da tainha de menjoada, todos os "sinais de memória" utilizados são criados a partir de um fundamento, o conhecimento tradicional da migração "lameirão-croa" da tainha:

A tainha de menjoada é à noite, né. À noite, quanto mais lombo da croa, melhor. De menjoada é o seco da croa. Mais fácil de matá peixe: que a tainha vai durmi na croa. (...). Do fundo ela vai pra cima das croa e tu vai achá ela lá. Ela procura a croa, ela vai durmí na croa. De dia ela tá no fundo, mas de noite ela procura a croa. (Moisés, 45 anos, pescador artesanal).

A tainha de menjoada se pesca no "seco da croa" durante o período noturno, porque a "tainha vai durmi na croa" ("Do fundo ela vai pra cima das croa e tu vai achá ela lá'). Quando a pesca de tainha de menjoada é fundada durante o dia, conforme visto anteriormente, devido ao vento nordeste que "tolda a água" ou à presença de "água doce", se pesca no "lameirão" ('De dia ela tá no fundo') (Tabela 3).

A escolha da croa para colocar as redes ('onde') é feita em função à movimentação da tainha "em cima das croa":

É conhecimento da gente, é claro o cara sabe, né, o jeito do peixe corrê, ressulhá, até nela pulá, as mareta, o cara sabe se é peixe miúdo ou peixe graúdo. Na fundura que a tainha tá também, o cara sabe... é uma coisa que não dá nem de explicá, é só o cara indo e aprendendo pra vê, né. A gente vê que tem bota a rede ali pra vê. (Amarildo, 40 anos, pescador artesanal).

Através de dois "sinais de memória", o "ressulho"250, as "maretas" e o "pulo"251, o pescador decide em qual "croa" colocar as redes de menjoada (Tabela 3).

A movimentação do cardume de tainha "em cima das croa" é também apropriada para o posicionamento das redes ('como'):

A tainha tu pode chegá em cima da croa e botá cinquenta rede aqui, tu matas peixe. Em qualqué lugá em cima da croa. Quanto mais saltiado tu botá, mais peixe tu mata: que ela dispara de uma rede, esbarra numa e vai na outra, entendesse. Agora, se tu botá ao correr tu matas peixe, mas mata menos. (Moisés, 43 anos, pescador artesanal).

\footnotetext{
${ }^{250} \mathrm{O}$ "ressulho" é a mudança repentina de direção no "corrê" do "peixe" gerando um "C" na superfície da água.

${ }^{251}$ Vale lembrar que para a pesca de lance, diferente da pesca de menjoada, o "pulo" é um sinal que funda a espera.
} 
As redes de tainha de menjoada durante a noite são colocadas "em cima das croa", tanto "ao correr" quanto "atravessado", inclusive das duas formas ao mesmo tempo ('Quanto mais saltiado tu botá, mais peixe tu mata'), devido à alta mobilidade da tainha ('que ela dispara de uma rede, esbarra numa e vai na outra') (Tabela 3). Foi observado, no entanto, duas situações em que alguns pescadores prefiriram colocar as redes de menjoada apenas "ao correr": quando queriam "matá peixe só pra cumê" e com a presença de "lixos".

Há também a pesca da tainha de menjoada "ali fora" em "anos de água salgada" e "de água misturada", como foi visto no item 4.4.1.1.3, pois só nestes cenários a tainha perfaz todo o seu ciclo migratório dentro do estuário. Para sair "ali fora", é necessário uma confluência de sinais:

\begin{abstract}
A tainha só vai saí de lá quando esfriá o tempo em abril-maio. Quando dé a corrida pra tainha. Que a tainha se mexe pra saí lá, pra í embora pro oceano, né. Ela vai se mexê lá na minguante de abril e minguante de maio. (...). Dá-le saragasso de vento rebojo, ela se movimenta de lá pra saí. (Sr. Meca, 68 anos, pescador-lavrador).
\end{abstract}

O vento "rebojo", a Lua minguante dos meses de abril e maio e o "frio" ('quando'), são sinais indissociáveis para que se inaugure a saída "ali fora", na croa do Diamente (Tabela 5).

Tal como "aqui dentro", quando se vai "ali fora", também é necessário o conhecimento do padrão migratório da tainha para o posicionamento das redes ('como'): "Depois vem a corrida. (...) e ela vem criada pra procurá o oceano pra í embora. E a gente coloca a rede atravessado pra pegá ela vindo" (Sr. Rui, 60 anos pescador artesanal). Devido o padrão migratório reprodutivo da tainha que "vem de cima", do norte da zona estuarina para o oceano, a "tainha de corrida", o posicionamento das redes na "croa do Diamente", que tem sentido Leste-Oeste, é "atravessado" (Tabela 5).

Há ainda um outro padrão migratório que é conhecido para se pescar a tainha de corrida "ali fora":

O dia que eu e o Evaldo fomo pescá de menjoada (...). Nóis botemo aqui: nóis botemo aqui assim ('de dentro') até a beira do canal pela beira da croa, né, pra pegá o peixe que vem do canal pro baixo. Botemo aqui pertinho do Diamante. (Moisés, 43 anos, pescador artesanal). 
Como "aqui dentro", "ali fora" também há a migração "fundo"-"baixo" ('do canal pro baixo') e vice-versa. É com base nele que as redes são posicionadas na "beira da croa do Diamante" ('onde') e, devido ao conhecimento da migração reprodutiva, “atravessado" ('como') (Tabela 5).

Portanto, a confluência de "sinais" que inauguram o "quando" (vento rebojo, minguantes de abril e maio, frio) da pesca da "tainha de corrida", também constróem o "onde" ('beira da croa do Diamante') e o "como" ('atravessado'), já que agrega o conhecimento ecológico tradicional da migração reprodutiva entre o oceano e o estuário e da migração entre "baixo" e "croa" ${ }^{252}$. Cessado a confluência de "sinais", abole-se a pesca da "tainha de corrida" e os coreanos retornam "aqui pra dentro".

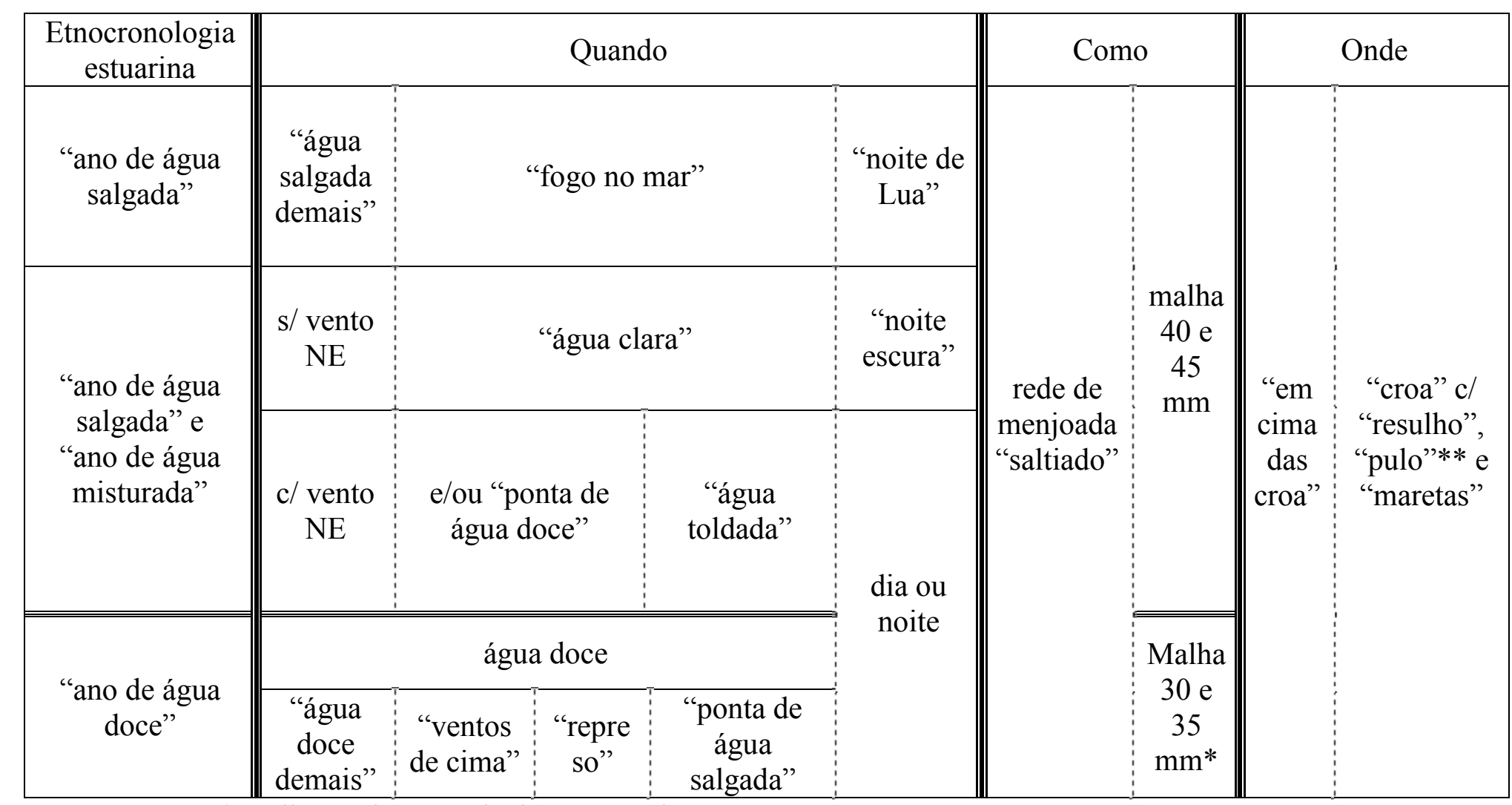

* malha também usada durante os "invernos".

** o pulo tem menor importância nos "invernos".

Tabela 3: Tomada de decisão para a pesca de "tainha de menjoada".

252 Também a migração "baixo"/“croa" obedece ao ciclo diário de migração de pescado e de movimentação dos pescadores descrito em 4.4.1.4, o que torna a pesca "ali fora" noturna. 


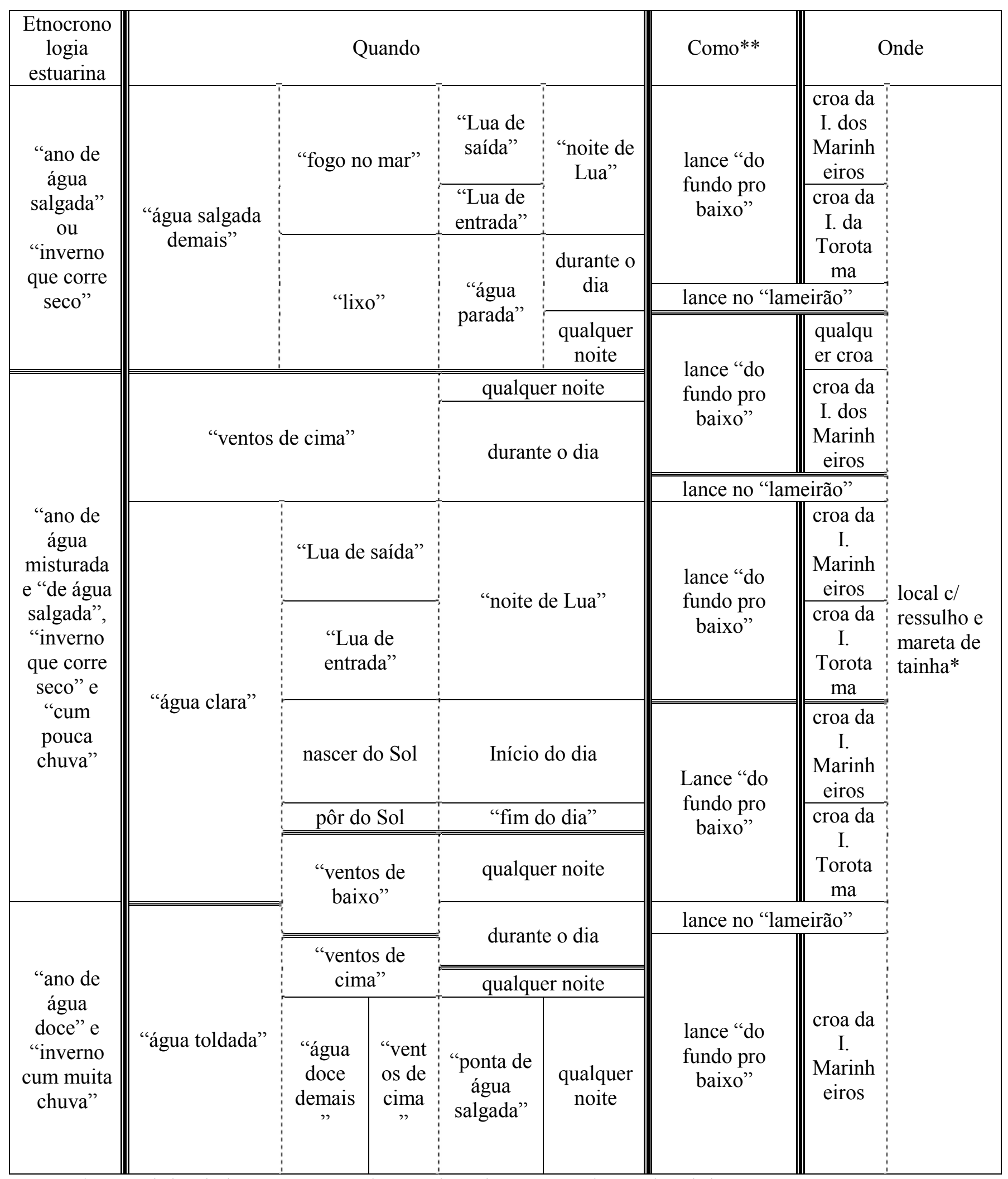

* na "tainha de inverno", o "pulo" também irrompe o "lance de tainha".

** As decisões sobre a malha na "tainha de lance" ocorre segundo as diferentes estações

e "anos de...", semelhante a "tainha de menjoada" (ver tabela 3).

Tabela 4: Tomada de decisão para a "tainha de lance". 


\begin{tabular}{|c|c|c|c|c|c|c|c|}
\hline \multirow{2}{*}{$\begin{array}{c}\text { Etnocronologia } \\
\text { estuarina }\end{array}$} & \multicolumn{4}{|c|}{ Quando } & \multirow{2}{*}{\multicolumn{2}{|c|}{ Como }} & \multirow{2}{*}{ Onde } \\
\hline & sair & ali fora" & colocar a & redes & & & \\
\hline $\begin{array}{l}\text { "ano de água } \\
\text { salgada" e "de } \\
\text { água } \\
\text { misturada" }\end{array}$ & $\begin{array}{l}\text { vento } \\
\text { rebojo }\end{array}$ & $\begin{array}{c}\text { Lua } \\
\text { minguante } \\
\text { de abril, } \\
\text { maio e } \\
\text { junho }\end{array}$ & $\begin{array}{c}\text { "no } \\
\text { saragasso } \\
\text { do vento }\end{array}$ & $\begin{array}{c}\text { "boca } \\
\text { da } \\
\text { noite" }\end{array}$ & $\begin{array}{c}\text { rede de } \\
\text { menjoada } \\
\text { "atravessado" }\end{array}$ & $\begin{array}{c}\text { malha } \\
45 \mathrm{e} \\
50 \\
\mathrm{~mm}\end{array}$ & $\begin{array}{l}\text { "beira de } \\
\text { croa" na } \\
\text { "croa do } \\
\text { Diamante" }\end{array}$ \\
\hline
\end{tabular}

Tabela 5: Tomada de decisão para a pesca da "tainha de corrida".

\title{
4.4.2.3. Tainha de inverno
}

As tomadas de decisão para a pesca da "tainha de inverno", em "inverno que corre seco" ou "cum chuva", se constróem da mesma forma que a pesca de tainha durante o "verão de água salgada" e "misturada" ou "de água doce", respectivamente, com exceção de apenas uma etapa: os "sinais" que indicam em qual croa ou lameirão ('onde') tem "peixe":

\begin{abstract}
A tainha no inverno, com frio, tem outro jeito também. A tainha de verão as veiz ela faz muito saragassu, a gente pensa que tem um monte de peixe, (...), e não é! É alarme falso! De inverno as veiz tu vai indo ela não dá sinal nenhum, as veiz pula uma tainhotinha ${ }^{253}$, tu lanceia e carrega um caíco. Tudo essas manha aí. (Amarildo, 40 anos, pescador artesanal).
\end{abstract}

A tainha de inverno "não dá sinal nenhum" porque a tainha fica mais quieta, "as veiz pula". Neste sentido, as "maretas" e os "ressulhos" ganham maior importância que os "pulos" para a pesca de menjoada, enquanto que antes fundavam um tempo de espera para o lance, passam a irromper o lance ('as veiz pula uma tainha, tu lanceia e carrega o caíco') (Tabela 3 e 4). Isso não quer dizer que a "boca da noite" e as Luas tenham perdido sua importância. Em campo, foram observadas a espera pela "boca da noite", "barrinhas do dia", "Lua de entrada" e "de saída", embora que com menor obstinação.

Uma outra diferença é com relação às redes ('como'). No "inverno", como a tainha ainda "não se criô", ou seja, ainda não atingiu um tamanho considerado "bom" para a pesca, a malha usada para a pesca é de 30 e $35 \mathrm{~mm}$, em vez dos $40 \mathrm{~mm}$ usados frequentemente no "verão" (Tabela 3 e 4).

253 "tainhota" = tainha pequena que ainda não atingiu o tamanho considerado "bom" para ser pescada. 


\subsubsection{Linguado}

Para a pesca do linguado duas técnicas são utilizadas: a rede de "menjoada" (rede de emalhar fixa/espera) e a "fisga" (arpão móvel).

Articulado a qualquer cenário de "inverno", na pesca de menjoada, um "sinal" é base para as tomadas de decisão:

O linguado, bom é botá rede cum água cheia. Dá um vento que ela vaze, dá vazantão, aí é bom! O linguado é um peixe que encosta, né, aí dá vazantão ele abre pra fora. O linguado gosta bastante de cumê ali na costa, na beira de uma croa. Então a água tá cheia, (...), ele vai lá em cima do baixo primeiro, aí dá vazantão ele sai pra fora. Aí é bom vazante. (Amarildo, 40 anos, pescador artesanal).

A “água cheia” permite que o linguado "vai lá em cima do baixo" ('a água tá cheia [...] ele vai lá em cima do baixo primeiro') e, quando a água vaza, ele retorna para o lameirão ('aí dá vazantão ele sai pra fora') ${ }^{254}$. É para evitar que o linguado cumpra este percurso, tanto de ida para o "baixo" quanto de volta para o "lameirão", que o pescador "bota as rede" ('bom é botá rede cum água cheia. [...]. Aí é bom vazante'). Neste sentido, a "água cheia" é um "sinal" que irrompe a pesca do linguado de menjoada, uma vez que constrói o "quando" pescar associando o conhecimento ecológico tradicional das condições hidrodinâmicas necessárias para o cumprimento do ciclo migratório entre "lameirão”-“croa” ('Então a água tá cheia, [...], ele vai lá em cima do baixo primeiro, aí dá vazantão ele sai pra fora') (Tabela 6).

O "sinal" "água cheia", no entanto, como agrega a interface entre a hidrodinâmica e a migração "lameirão"-“croa", não indica somente o "quando", mas também em que local ('onde') e a posição da rede ('como'):

\footnotetext{
A rede de linguado o cara bota ao correr da água (...) e tem que sê berinha de croa: (...) que o linguado vem durmi na croa, ele vem do fundo pra durmi na croa. De manhã, quando amanhece o dia, ele vum pra fora. Abre um risco: é a hora que ele malha, que ele vai procurá o fundo. $\mathrm{E}$ as veiz quando ele vem do fundo pra terra ele malha. $\mathrm{O}$ linguado malha dos dois lado da rede: tanto pra croa como da croa pro fundo. (Moisés, 45 anos, pescador artesanal).
}

\footnotetext{
${ }^{254}$ As "croas" com "lixo-capim" são as preferidas pelos linguados: "Linguado também gosta de ficá na beirada do lixo-capim. É, mas o linguado é pra pegá o peixinho que tem no meio do lixo. (...). O linguado come peixe" (Guega, 54 anos, pescador artesanal). Consequentemente, os pescadores colocam as redes preferencialmente nestas "croas".
} 
Com a "água cheia", as redes de menjoada (rede de espera) devem ser colocadas na "beirinha de croa" e "ao correr da água" para evitar que o linguado cumpra sua migração entre a "croa" e o "lameirão",255 ("que o linguado vem dormi na croa [...]. De manhã, quando amanhecer o dia, [...] ele vai procurá o fundo') (Tabela 6).

Há, no entanto, algumas variações no "onde” colocar as redes de linguado:

É sempre igual: se tivé baixa, tu procura botá mais pra dentro do fundo um pouquinho. Mas sempre pela beira da croa. A não sê cum ano de enchente, né, um ano que seje de água muito alta que nem foi nesse El Niño, aí tu tem que botá em cima da lomba. De repente tu bota mais aqui em cima da lomba do que lá (na beira), entendesse. (Moisés, 45 anos, pescador artesanal).

Quanto mais baixo o nível (altura) da água, mais próximo ao "lameirão" a rede deve ser colocada, mas ainda na "beira de croa" ('se tivé baixa, tu procura botá mais pra dentro do fundo. Mas sempre pela beira da croa'). Por outro lado, se as águas estiverem "muito altas", há a possibilidade das redes não serem colocadas na "beira de croa", mas “em cima da lomba” ('um ano que seje de água muito alta que nem foi nesse El Niño, aí tu tem que botá em cima da lomba'). O primeiro caso é mais frequente em "inverno que corre seco", enquanto o segundo ocorre apenas em "inverno cum muita chuva" (Tabela $6)$.

A decisão a respeito de qual "croa" as redes vão ser colocadas ('onde') é feita mediante alguns "sinais":

Geralmente é assim ó, que nem eu quando ia botá rede: 'Bah, aqui, como tem cama de linguado! Vô botá a rede aqui que aqui dá linguado’. E dava mesmo! (...). Era o lugar que ele parava mais. Outras veiz, tu vai botá a rede, tu vê um linguado-dois corrê, fica um risco assim n'água. Tu bota rede que dá linguado também. (Sindo, 40 anos, pescador artesanal).

Neste sentido, a "cama de linguado" e o "risco n'água" são "sinais' que indicam as "beiras de croas" onde devem ser colocadas as redes para obter sucesso na pescaria (Tabela 6).

No entanto, a "água cheia", por si só, não constrói o "quando", ou seja, geralmente não rompe a latência da espera. Há dois outros "sinais" que se articulam à "água cheia":

\footnotetext{
${ }^{255}$ O esquema de tomada de decisão é o mesmo para o "lixo-capim", pois o "lixo capim" nasce "em cima das croa". A única diferença é que a "croa" e o espaço da "croa" com "lixo-capim" torna-se um local mais disputado para se colocar as redes de linguado.
} 
As veiz deixa as redes todo o dia na água. Mas de dia é difícil dá linguado, só se a água tivé suja. (Sindo, 40 anos, pescador artesanal).

À noite o linguado não precisava vento pra saí pra pescá-lo. Mas de dia o nordeste é o milhór vento pra ele malhar. Qualqué vento é bom porque movimenta com ele, ele se atira milhór na rede. Cum vento fica um saragasso e ele acaba não vendo a rede. Já cum calmaria ele tem tempo pra contemplá a rede. (Sr. Dino, 67 anos, pescador artesanal).

De dia só se fô cum água doce. (...). Tolda a água, aí o linguado dá durante o dia, né. (Sr. Meca, 68 anos, pescador artesanal).

A "água suja" ou "toldada" é um "sinal” produzido pela recorrência de outros fenômenos como o vento ('Qualquer vento é bom porque movimenta com ele, ele se atira milhór na rede'), sobretudo o NE ('o nordeste é o milhór vento pra ele malhá'), e a presença de "água doce” ('De dia só se fô cum água doce'), que em geral é "toldada", que evitam que o linguado "veja" a rede de menjoada ('ele acaba num vendo a rede') durante o dia. Neste sentido, a "água toldada" funda a pesca de linguado de menjoada durante o dia ('Tolda a água, aí o linguado dá durante o dia').

O que se diferencia entre os cenários de "inverno" são os "sinais" que "tolda a água": no "inverno que corre seco" o "vento" gera "água toldada" durante o dia e, portanto, é o "sinal" que articulado às "águas cheias" fundam a pesca durante o dia; no “inverno cum chuva" já que a "água doce”, em geral, é "toldada”, articulada ao "sinal" "águas cheias", funda a pesca de linguado durante o dia ${ }^{256}$ (Tabela 6). Portanto, os dois cenários de "inverno" possibilitam a pesca durante o período diurno e o noturno.

No entanto, nem sempre a "água doce" está "toldada": "A água de Pelotas é meia avermelhada e a de Porto Alegre é meia branca. A água de Porto Alegre as veiz tá clarinha também. A água de Pelotas não" (Sr. Dino, 67 anos, pescador artesanal). Nestes casos em que "a água de Porto Alegre tá clarinha", a pesca do linguado no cenário de “inverno cum chuva", as tomadas de decisão são tal como no "que corre seco".

Além dos "sinais" que fundam a pesca do linguado durante o período diurno, há também aqueles que suspendem a pesca de linguado à noite: "Lua pra pescaria de linguado... noite de Lua escura acho que é milhór. Noite de Lua num presta porque o linguado vê as rede" (Sr. Zezinho, 60 anos, pescador-lavrador). A "noite de Lua" é considerada ruim para a pesca, porque permite que o linguado "veja" as redes. Neste

\footnotetext{
${ }^{256}$ Vale lembrar que quando há a presença de "água doce" no estuário, em geral, estão "cheias", segundo os pescadores da Coréia.
} 
sentido, durante todo o quarto de Lua cheia a pesca do linguado é abolida, mas refundada no próximo quarto de Lua (Tabela 6).

Em noites de Lua cheia ('noites de Lua'), por outro lado, há a possibilidade de outros fenômenos da natureza impedirem que o linguado "veja a rede", como as nuvens, o vento e a água doce: "Se a noite for de lua, mas tivé anuviada ${ }^{257}$, aí já é milhó, aí já dá. Noite anuviada já fica mais escura, né. Aí já dá. Aí ele dava cum a noite anuviada, dava" (Sr. Dino, 67 anos, pescador artesanal); "Ah, o linguado, o linguado atrapalha a noite de Lua. (...). Só se tivé vento ou água doce pra podeis matá ele: aí claro, suja a água ele se mexe" (Gordo, 39 anos, pescador artesanal). Qualquer evento natural que diminua a claridade da Lua nas águas (nuvens e 'água toldada') favorece a pesca de linguado mesmo em "noites de Lua" no cenário de "inverno que corre seco" ('água salgada' e 'clara'). No cenário de "inverno cum chuva”, a água doce, que é toldada, já é um "sinal" favorável à saída para a pesca em qualquer uma das noites, pois a claridade da Lua não afeta a visibilidade das redes pelo linguado (Tabela 6).

No cenário do "inverno que corre seco", há implicações para a pesca do linguado quando a "água corre muito tempo salgada". Neste caso, funda-se um tempo de latência para a conformação, ou não, de dois "sinais": "lixos" e a "água salgada demais". A presença de "lixos" provoca um período de suspensão da pesca de linguado:

\footnotetext{
Linguado até tem algum aí é que num calha feição que nem esse ano. Esse ano tem algum peixinho aí é que num dá pro cara trabalhá: os cara botam uma redinha á e no mesmo dia é uma carga de lixo, né, cara. (...). Eu acho que esse ano o cara matava uns linguado. (Moisés, 45 anos, pescador artesanal).
}

Os "lixos" impedem a pesca do linguado mesmo que ela já tenha iniciado, porque "embuxa as rede" e as destrói ("os cara botam uma redinha e no mesmo dia é uma carga de lixo'). No caso dos "lixos", diferente do "fogo no mar", tem um período do "ano" em torno do qual ele aparece, entre o "verão de água salgada" e um "inverno", e desaparece do território coreano assim como foi discutido para a tainha em 4.4.2.2.

Já a "água salgada demais" é um "sinal” que, sucedido e associado a outro "sinal", o "fogo no mar", constrói um outro cenário de tomada de decisões que impede a saída para a pesca do linguado:

257 "anuviado" = nublado. 
Água muito, muito salgada também é ruim. Aí o linguado vê aquela água viva, né, aquele fogo na água, vê a rede num malha. Uns chamam de ardentia, outros chamam de água viva. (...). Mexe a rede, né, e faz um fogo na rede, o peixe num malha. (Evaldo, 36 anos, pescador artesanal).

O "fogo no mar" pode ocorrer em qualquer época do "ano" em que "a água corre sempre salgada", "inverno" ou "verão". No entanto, no contexto do "fogo no mar”, abre-se também no linguado um hiato na suspensão da sua pesca pela recorrência de um "sinal", a Lua cheia ('noites de Lua'):

\footnotetext{
Num tem Lua, a água tá muito salgada, aí ela larga aquele fogo no mar. Então quando a Lua nasce, aquilo desaparece e é quando ele malha. (...). Então a Lua nasce e aquele fogo se some. (...). Nem um peixe malha cum aquela ardentia, (...). Mas depois que aquilo desaparece, a Lua alteia e aquele clarão. (Dino, 67 anos, pescador artesanal).
}

As "noites de Lua" que, nos "invernos que corre seco", contróem um cenário "ruim" para a pesca de linguado, neste contexto engendram uma trégua na suspensão da pescaria de linguado abrindo possibilidades para a saída dos coreanos para a pesca durante todo o período de Lua cheia ('Então a Lua nasce aquilo desaparece e é quando ele malha') (Tabela 6).

Além das "aguas cheias", as "águas baixas" também podem impulsionar o homem coreano ao "mar" na pesca de linguado: "Quanto mais baixa (a água), milhór pro linguado de fisga. Dia ou noite, quase sempre ele tá dentro do fundo, né. Aí cum água baixa é milhór de procurá nos fundinho que tivé. Ele num procura muito as croa não" (Evaldo, 39 anos, pescador artesanal). Com as "águas baixas" o linguado não cumpre sua migração nictimeral "lameirão"-“croa" mantendo-se em maior abundância no "lameirão" ('Dia ou noite, quase sempre ele tá dentro do fundo'), o que propicia a pesca de "linguado de fisga" ('Quanto mais baixa, milhór pro linguado de fisga'). Neste sentido, a "água baixa" é um sinal que irrompe a pesca do linguado de fisga, uma vez que constrói o “quando" ('água baixa'), “como” ('de fisga') e “onde” ('no fundo') pescar, associando o conhecimento ecológico tradicional das condições hidrodinâmicas necessárias para o não-cumprimento do ciclo migratório entre "croa" e "lameirão" (Tabela 7).

Ao contrário da pesca de menjoada em que o vento algumas vezes é necessário para o irrompimento da atividade pesqueira, como foi visto acima, na pesca do "linguado de fisga" o vento funda um tempo de espera: "Quando caía gelo o cara ia pro linguado de fisga. A gente ia assim de calmaria de rebojo, bem calminho. Então tu via lá 
no fundo d'água, água bem clarinha, o linguado como morto e a gente fisgava" (Sr. Zé, 70 anos, pescador artesanal aposentado). $\mathrm{Na}$ pesca de "fisga", na duração do vento "rebojo" se "chuleia" a sua "calmaria" que abre possibilidades para a ação, para a pesca (“A gente ia assim de calmaria de rebojo'). Á “calmaria de rebojo" associa-se outros "sinais" para a tomada de decisões na pesca matutina: "água clarinha" e "gelo" (geada) (Tabela 7).

Já para a pesca noturna, a confluência de "sinais" é outra:

Fisga só no fim da safra de camarão agora, em fim abril cum essas calmaria. (...). Calma de rebojo, essas calma aí. No fim de abril agora tem muita calmaria, né. Noite calminha e fria, água clara... tem que tê água clara, né, e salgada. É, e bom pra linguado de fisga é a noite escura, né, noite de Lua já é meio ruim. (Amarildo, 40 anos, pescador artesanal).

Para a tomada de decisões na pesca "de fisga" noturna, a "calmaria de rebojo", a "água clarinha" e a "noite escura" é o conjunto de "sinais" necessários à construção do “quando" sair para pescar linguado (Tabela 7).

O "sinal" "água clarinha" associada à "calmaria do vento rebojo" traz algumas implicações quanto ao cenário de ocorrência da pesca de fisga: "Esse linguado que entra é agora (...) no inverno, é mais no tempo frio de junho inté setembro. (...). Entra as ponta de água salgada cum aqueles rebojo e o linguado vem pra nóis aqui” (Sindo, 40 anos, pescador artesanal). Na espera pela "calma do rebojo" está implícita a espera pela entrada de linguado do oceano em nosso mar em "pontas de água salgada" ('água clarinha') durante o cenário de "inverno que corre seco" e "cum pouca chuva". Portanto, neste caso, a "água clara" não pode ser a "água doce de Porto Alegre”, pois os "sinais de memória" ('calmaria de rebojo' e 'água clara') materializam o tempo na dinâmica da entrada de "água salgada” em "nosso mar" e não de "água doce”.

No linguado de fisga, a escolha do "fundo" onde pescar é feita mediante um "sinal":

Eu gostava mais de pescá de noite, de dia ele é muito esperto: ah, ele te vê na água clara. Eu custava a vê, quando via ele já saía correndo. De noite não, ele fica bobo aí, fica bobo na luiz ${ }^{258}$. (...). Aí tu vê ele, o formato dele assim na areia. E de dia ele se enterra mais, as veiz tá só os ólho dele, bah, é difícil (...). Ele vê a sombra do cara e se manda, que ele é um peixe rápido, né. (Sindo, 40 anos, pescador artesanal).

\footnotetext{
${ }^{258}$ Os pescadores da Coréia usam para a pesca noturna lâmpadas próximas às redes ou, no caso da pesca de fisga, na proa do caíco. Estas lâmpadas são mantidas à gás ('liquinho') ou à bateria de automóvel.
} 
Assim como para o "linguado de menjoada", a "cama do linguado" também constitui "sinal" que indica em qual "fundo" pescar o linguado de fisga ("Aí tu vê ele, o formato dele assim na areia') (Tabela 7). Devido ao comportamento migratório ('de dia ele se enterra mais') e à fotossensibilidade do linguado ('de noite ele fica bobo na luiz') o turno da noite é preferido por alguns pescadores para a pesca do linguado ('Eu gostava mais de pescá de noite').

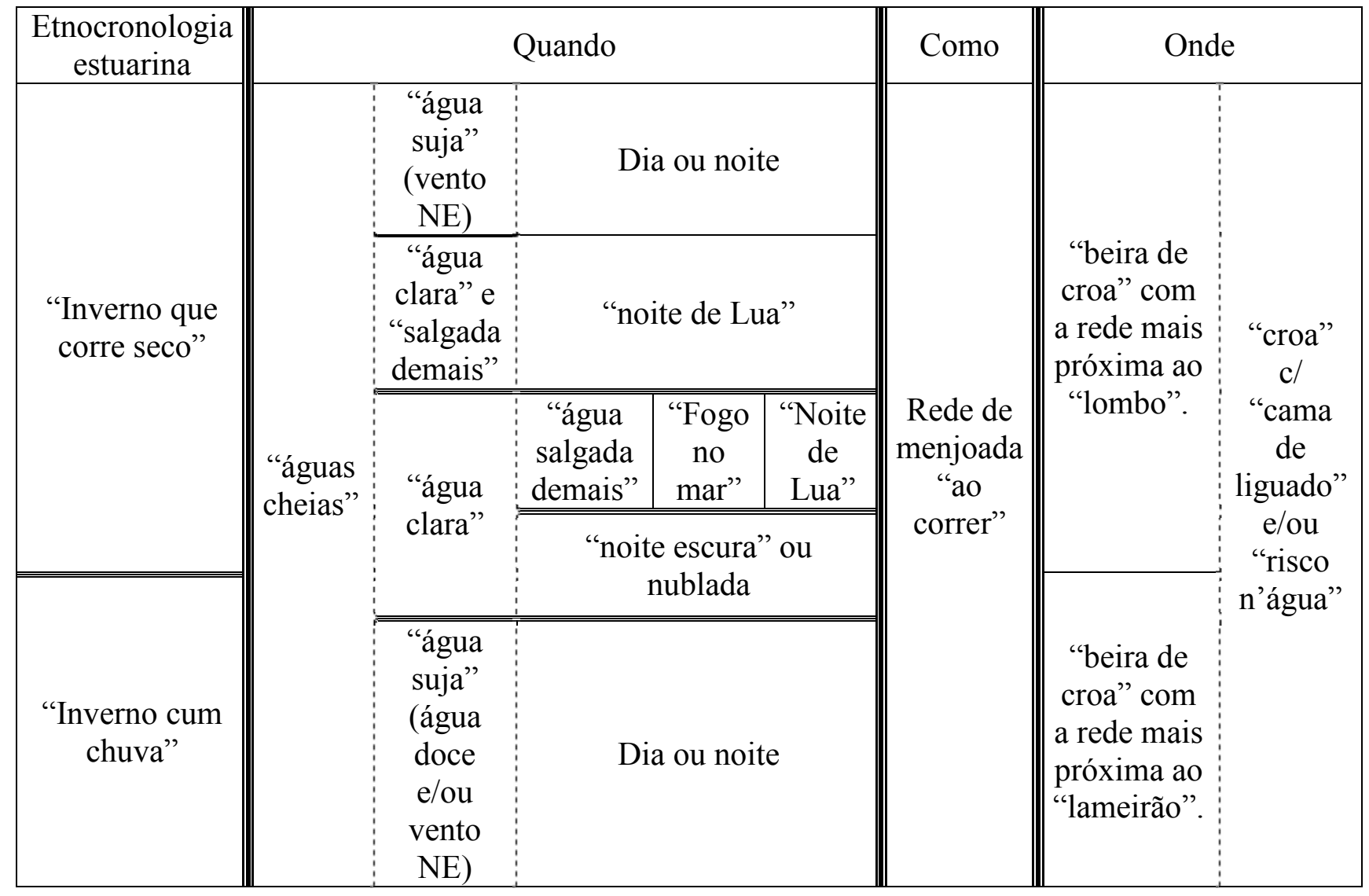

Tabela 6: Tomada de decisão para a pesca do "linguado de menjoada".

\begin{tabular}{|c|c|c|c|c|c|c|c|}
\hline Etnocronologia & \multicolumn{5}{|c|}{ Quando } & Como & Onde \\
\hline \multirow{2}{*}{$\begin{array}{l}\text { "inverno que } \\
\text { corre seco" e } \\
\text { "inverno cum } \\
\text { pouca chuva" }\end{array}$} & \multirow{2}{*}{$\begin{array}{l}\text { "Calmaria de } \\
\text { rebojo"/geada }\end{array}$} & \multirow{2}{*}{$\begin{array}{c}\text { "Água } \\
\text { baixa } \\
\text { e } \\
\text { clara" }\end{array}$} & \multicolumn{3}{|c|}{ dia ou "noite escura" } & \multirow{2}{*}{$\begin{array}{l}\text { "de } \\
\text { fisga" }\end{array}$} & \multirow{2}{*}{$\begin{array}{c}\text { "lameirão" } \\
\text { c/ "cama } \\
\text { de } \\
\text { linguado" }\end{array}$} \\
\hline & & & $\begin{array}{l}\text { "salgada } \\
\text { demais" }\end{array}$ & $\begin{array}{l}\text { "fogo } \\
\text { no } \\
\text { mar" }\end{array}$ & $\begin{array}{c}\text { "noite } \\
\text { de } \\
\text { Lua" }\end{array}$ & & \\
\hline
\end{tabular}

Tabela 7: Tomada de decisão para a pesca do "linguado de fisga". 
A partir do encontro de pontos de abundância de pescado ocorre a apropriação destes locais inaugurando um conjunto de relações sociais de divisão, posse, competição e cooperação destes/nestes espaços. A posse de determinado local/ponto de pesca ('pesqueiros') será visto no próximo item.

\section{5. “Andanas" e pesqueiros: "O meu lugá é esse aqui”.}

Como foi visto no item anterior, para se decidir onde, como e quando "botá as rede", seja fixa ou móvel, é necessário um conhecimento profundo das principais forçantes estuarinas, do comportamento migratório dos recursos pesqueiros e da interação de ambos, que se constrói mediado pelas técnicas de pesca. Por isso que, conforme foi visto, o tipo de petrecho usado constitui uma estratégia adaptativa dos pescadores coreanos à dinâmica percebida do ecossistema estuarino. Segundo Cordell (1983; 1989), é a partir do requerimento micro-ambiental por petrecho e da dinâmica ambiental que se engendram os sistemas de posse no mar. Neste sentido, este item tem o objetivo de descrever o sistema de posse no mar que se constitui nas "safras" de camarão, tainha e linguado e que, assim, condensam o tempo daquela safra. No entanto, uma discussão introdutória sobre alguns padrões gerais de posse que perpassam todas as safras deve ser feita a fim de subsidiar as discussões subsequentes de cada safra escolhida.

A primeira regra de posse que perpassa todas as safras atua a partir da tomada de decisão de onde "botá as rede". Decidido onde "botá as rede", a primeira regra de apropriação é a de "quem chega primeiro":

\footnotetext{
...a gente vai indo assim e eu cheguei lá já tinha lugares, num tinha rede, mas tinha taquaras cravada, e eu notei e o Leandro que tinha gente pescando. Digo: 'Não, aqui num vamo botá rede, pois é incomodação, coisa que a gente num deve fazê. (Sr. Zezinho, 60 anos, pescador-lavrador).
}

No entanto, a apropriação de determinado espaço do "mar", e, portanto, de fundação de um pesqueiro, se dá, geralmente, enquanto o pescador ou suas redes se fazem presentes. A regra "de quem chega primeiro" na constituição de pesqueiros foi 
registrada por Begossi (2004) no litoral de São Paulo e por Diogo et al (2008) no litoral sul da Bahia.

No item 4.4.2, foi visto que, a partir da escolha do local de pesca, a construção do pesqueiro engendra-se à forma de se "botá as rede" (a 'feição das rede'). Como as artes de pesca fixas são colocadas estrategicamente num determinado ponto do mar na espera do emalhe do "peixe" que tenta cumprir a sucessão natural do seu movimento migratório, há uma distância da rede que é apropriada ('Ali, onde fulano tá pescando é dele... enquanto ele tivé ali é dele. (...). Na frente dele também não, ninguém pode botá senão tapa ele, né, ô' - Guega, 54 anos, pescador artesanal), pois se considera que os recursos pesqueiros contidos ou que passarão por aquele espaço pertencem ao espaço de atuação daquele petrecho de pesca. Estes espaços apropriados por petrechos fixos são, segundo Cardoso (2001), um dos indícios de territorialidade no mundo pesqueiro, na medida em que o espaço que se apropria é um certo "trecho de água".

Já nas artes de pesca móveis, usa-se do conhecimento do comportamento migratório "lameirão"-“croa" dos "peixes", mas não há uma espera pela sua sucessão natural, como também foi visto no item 4.4.2. Contrário da pesca fixa em que o peixe vai até o apetrecho de pesca, na tentativa de cumprimento do seu ciclo migratório, nas artes de pesca móveis não há espera, mas o movimento ativo de captura do pescado. Ou seja, no petrecho móvel é o pescador com o petrecho de pesca que vai até o pescado após a localização de um pesqueiro. Em movimento, a atuação se dá em vários pontos do mar ('quando a gente vai de lance a gente corre esse mar todo aí' - Sr. Dino, 67 anos, pescador artesanal), sendo que em cada um destes pontos o tempo de permanência em relação às artes de pesca fixa é curto. A mobilidade, no entanto, não é empecilho para a apropriação de um espaço aquático, como pode ser exemplificado pelo cerco de tainha: “Pode lanceá do lado que num dá nada. (...). Por cima não, lanceá por cima não, aí não... o que tá dentro do lance é meu" (Sr. Dino, 67 anos, pescador artesanal). Não só há a apropriação de um espaço aquático pelo lance, como também pelos "peixes" nele contidos restrito ao alcance físico da unidade de apropriação. Por isso, Silva (2006) pondera que a mobilidade do território é relativa à mobilidade do petrecho e à piscosidade da mancha de pescado que, por sua vez, também possui certa mobilidade ${ }^{259}$.

\footnotetext{
${ }^{259}$ Silva (2006) ilustra o território móvel com o uso da tarrafa dos pescadores do rio Ituquara que, por ser móvel, necessita que o pescador empregue uma embarcação o que, segundo o autor, aumenta a territorialidade do pescador.
} 
Neste sentido, ambas as artes dispõem de um mecanismo de delimitação atrelado ao conhecimento ecológico tradicional e ao tempo de atuação num ponto de pesca. Nas artes móveis o espaço apropriado não rompe com os limites físicos da unidade de apropriação, o que nas fixas acontece, embora haja limitações sob influência física dos petrechos de pesca, ou melhor, limitações impostas pelo tamanho do petrecho. Assim como na Coréia, no rio Ituquara, segundo Silva (2006), a territorialidade instituída sobre um trecho de água pelo petrecho fixo depende do seu tamanho. Portanto, uma microárea é apropriada, delimitada e um conjunto de relações sociais se fundam no sentido de controlar o acesso aos recursos pesqueiros o que, sob a perspectiva de Cordell $(1974 ; 1983 ; 1989)$, funda um pesqueiro.

Esta interpretação do conceito de "pesqueiro" cunhado por Cordell tem um desdobramento diverso às interpretações de alguns autores brasileiros como Begossi (2000; 2004; 2006). Em suas pesquisas, Begossi considera plausível duas hipóteses que se desdobram do conceito de pesqueiro: "Quanto menos móvel for uma tecnologia de pesca, maior a probabilidade de encontrar territórios ou regras de uso (pesqueiros)" ou, no caso de pescados com alta mobilidade, como é o caso da tainha, "Quanto mais móvel uma presa, menor a probabilidade de haver delimitação de territórios" (: 227). A partir disso, verifica-se, subjacente à leitura de Begossi sobre os "pesqueiros" de Cordell, a crença de que um "pesqueiro" tem maior "probabilidade" de se construir quando fixado no espaço por um longo período de tempo, o que condena o "pesqueiro" certa imobilidade. Neste sentido, diferentemente da interpretação de autores como Begossi, na descrição da constituição dos "pesqueiros" que é feita subsequentemente para cada safra estão inclusos os pestrechos de pesca fixos e móveis, embora, de longe, as técnicas de pesca fixa (ou redes de espera) são as mais utilizadas pelos pescadores da Coréia. Todos os recursos pesqueiros explorados por eles, eminentemente de água salgada, como foi visto no item 4.1, são capturados por alguma arte de pesca fixa, embora, historicamente, nem sempre tenha sido assim ${ }^{260}$.

\footnotetext{
260 Até fins da década de 1970 e início de 1980, alguns recursos pesqueiros, como o camarão, eram capturados apenas por artes de pesca móveis e outros, como a corvina e o peixe-rei, eram capturados por artes de pesca fixas e móveis (no caso, os 'lances'). A imposição de leis e a decadência da pesca no Estuário da Lagoa dos Patos, a partir do final da década de 1970 e início de 1980 (HAIMOVICI et al, 2006), explicam a situação contemporânea de predominância das artes de pesca fixa. Curioso é a pescaria de siri que, na Coréia, praticamente não existia até o início dos anos $1980 \mathrm{e}$, a partir daí, passa a ser realizada com artes de pesca fixa e móvel. No entanto, sobretudo nas pescas em que ainda se permite algum excedente de subsistência, ainda se utiliza com maior frequência pesca móvel como no caso da tainha, do camarão e do siri. Por fim, deve-se ressaltar que, apesar da pescaria móvel de peixe-rei, de corvina e de linguado terem praticamente desaparecido, muitos ainda possuem estas artes de pesca nos
} 
Os pesqueiros na Coréia podem ser apropriados individualmente ('Eu pesco solito') ou em grupo ('Vô eu e meus guri pescá'). Cardoso (2001) observa estas duas formas de apropriação territorial em ecossistemas lagunares e estuarinos do sul do Brasil. Um detalhe importante de quando a pesca se dá em grupo, é a apropriação do pesqueiro na Coréia pelo "bote" ou pelo "caíco", em concordância com Maldonado (1993) quando descreve o "bote" como unidade de produção na pesca e apropriação das "pedras"261 no nordeste brasileiro. A predominância de artes de pesca fixa, junto com políticas do governo estadual e federal nos anos 1990 que permitiram a disseminação entre os "proeiros" de artes de pesca (SOUZA, 2001; PASQUOTO, 2005), fizeram da Coréia um dos vários lugares da Lagoa dos Patos em que hegemonicamente se pesca sozinho $^{262}$. Mas ainda subsiste a pesca com patrão e proeiro, embora o patrão tenha perdido poder e os proeiros, número ${ }^{263}$.

Pode-se dizer, portanto, que é em torno dos conhecimentos dos padrões migratórios e das técnicas de pesca que as relações de divisão e de posse dos pesqueiros coreanos se constituem. Ainda que de grande mobilidade e aparentemente indiviso, Maldonado (1988) também aponta estes dois critérios na construção do território no meio marítimo. Como consequência da fundação de pesqueiros, segundo Thornton (1980), relações de territorialidade como a cooperação e a competição também se instalam.

Uma das relações de cooperação é o respeito à posse e à manutenção da posse do pesqueiro ('Aqui dentro a turma [os coreanos] respeita' - Moisés, 45 anos, pescador artesanal), segundo as regras locais que emergem a cada safra, embasadas nas técnicas de pesca e no conhecimento ecológico tradicional. Neste sentido, encontra-se consonância em Maldonado (1993), onde a noção de respeito se articula com o processo de apropriação do mar de acordo com valores e comportamentos perante os homens e/ou a natureza.

Por outro lado, há a desarticulação do respeito "aqui dentro", através dos roubos ('Hoje não tem mais segurança prá trabalhá' - Sr. Dino, 67 anos, pescador

galpões, o que mantém um potencial imanente destas práticas em anos que estas pescas por ventura abundem novamente nas águas da Coréia.

261 "pedras" = "pesqueiro".

262 PASQUOTTO (2005) cita vários lugares ao longo da Lagoa dos Patos em que um pescador sai sozinho em sua embarcação para a atividade pesqueira.

263 Até a década de setenta, na Coréia era comum uma "parelha" conter 5 pessoas entre "patrão", "proeiro", "chumbereiro" e "batedor". Atualmente é comum a presença de duas pessoas por "parelha". 
artesanal), e "ali fora" e "aqui dentro", devido à desigualdade na alocação de recursos ('Hoje a máquina dá esse delúvio de rede aí' - Sr. Meca, 68 anos, pescador-lavrador), o que caracteriza uma competição espacial destrutiva segundo Cordell (1983).

A competição espacial destrutiva poderia corroborar a teoria da tragédia dos comuns de Hardin onde o comportamento individualista em comunidades pesqueiras traria a derrocada da pesca (CORDELL, 2001). No entanto, uma série de respostas adaptativas são criadas, de ação individual ou em grupo, a partir das causas da desarticulação do respeito mostrando certa capacidade de autogestão da Coréia, inclusive intercomunitariamente. Neste sentido, Cordell (2001) ressalta que os autores da tendência da Tragédia dos Comuns de Hardin não levam em consideração as relações de cooperação que limitam a competição espacial potencialmente destruidora.

Uma relação de territorialidade observada em conversas informais entre os pescadores, nas festas e nas "vendas" ${ }^{264}$ e na observação participante, e que perpassa todas as safras, é a difusão de informações que, por sua vez, oscila entre a cooperação e a competição. Outros autores como Cordell (1983; 1989), Maldonado (1988) e Ramalho (2006) também observaram esta dualidade da difusão de informações.

$\mathrm{Na}$ Coréia, a dispersão de informações consideradas verdadeiras, os alertas sobre "sinais de memória" ou a transmissão de conhecimentos sobre o padrão migratório das espécies vinculado às forçantes hidrodinâmicas, se dá, sobretudo no início e no princípio das safras e em momentos durante a safra em que há alguma mudança ambiental significativa, ou seja, qual safra está começando ou terminando, a entrada e a saída de "peixes", migração do pescado entre "croa" e "lameirão", padrão de enchente e de vazante, dos ventos e da chuva, previsões de safra, etc. Estas informações têm a função de situar o grupo no tempo e no espaço das relações sócio-ambientais.

Por outro lado, informações sobre locais específicos de manchas de determinado pescado e como otimizar uma técnica de pesca em determinado local sob certas condições ambientais são mantidas em segredo e/ou falseadas: "Se os marimbondo ficasse sabendo onde se deu peixe, noutro dia tava cheio de gente lá. Então, a gente tinha que, muitas veiz, não dizê nada: 'Ah, pesquei em tal lugar...' e deu!" (Sr. Dino, 67 anos, pescador artesanal). O "não dizê nada" tem uma clara função de proteção de pesqueiros por diminuir a pressão sobre os recursos, consoante ao que

264 "Vendas" = bares ou "botecos". 
atestam autores como Ramalho (2006) sobre a ética do segredo e Cordell (1983; 1989) e Begossi (2000) sobre a difusão de informações contraditórias.

Esta dinâmica da informação, que oscila entre a revelação e o segredo, segundo Maldonado (1993) é uma estratégia de interação social e de posse e manutenção da posse no mar.

Quando a pesca envolve mais de uma pessoa, no entanto, foi observado que o segredo sobre pesqueiros é imbuído de dois significados: relação de cooperação entre aqueles que pescam juntos, na medida em que a informação é compartilhada por todos, e de exclusão com aqueles que não pertencem a este grupo. Neste sentido, a utilização do segredo revela a capacidade dos pescadores de se relacionarem com pescadores de outro bote sem, no entanto, abandonarem a fidelidade e a reserva com "as coisas do bote" a qual pertencem (MALDONADO, 1993: 155).

Apesar destes padrões gerais que permeiam todas as pescas que acontecem no "nosso mar", a cada nova safra uma forma de zoneamento do mar e um conjunto de relações sociais de territorialidade se fundam, tanto de cooperação quanto de exclusão (CORDELL, 1983; 1989; CUNHA, 2007). Estas diversas particularidades em torno dos "pesqueiros" serão definidas a seguir de acordo com cada tipo de espécie de pescado.

\subsubsection{O camarão: “Cada um JÁ tem o seu lugá...”.}

$\mathrm{Na}$ atualidade, a Coréia é especialista na pesca do camarão-rosa. Além de ser o principal recurso pescado, no camarão se permanece mais tempo pescando. A pesca do camarão constitui um caso especial em que há incidência da Instrução Normativa Conjunta de 9 de fevereiro de 2004 (INC) $)^{265}$, que normatiza a posse e usos de pesqueiros com rede fixa. O local onde se coloca as redes, chamado pela INC (2004) de "andainas"266 267, deve ser registrado anualmente no Instituto Brasileiro do Meio

\footnotetext{
${ }^{265}$ Instrução Normativa Conjunta $\mathrm{n}^{\circ} 3$ de 9 de fevereiro de 2004.

266 "Andaina” é um pesqueiro que goza de regulamentação formal de posse e uso. No Rio Grande do Sul, há uma prática de registro e regulamentação de pesqueiros de redes fixas de camarão que, ao que indica as entrevistas, remonta ao "tempo da SUDEPE". Segundo entrevistas com pescadores mais velhos, as antigas andanas de bagre e de corvina, que não existem mais, eram utilizadas para a pesca da "tainha de corrida" e surgiram anteriormente às andanas de camarão, cuja primeira normatização data do princípio dos anos 1980. Neste sentido, provavelmente as primeiras normatizações para a pesca do camarão herdaram regras das andanas do bagre e da corvina.
} 
Ambiente e dos Recursos Naturais Renováveis (IBAMA) que, por sua vez, concede permissão de uso somente deste local, com no máximo 10 redes, durante toda a safra. Há uma tendência de os pescadores registrarem estas andanas próximas às suas residências. A rede "aviãozinho" ${ }^{268}$, artes de pesca fixa (ou de espera), é a única permitida em zonas baixas, como o Saco do Arraial, e, por isso, a mais utilizada, de fato, na Coréia.

O registro de andana imposto pela ICN (2004) é conhecido por todos, mas a sua incidência não desarticula a regra do "quem chega primeiro" na pesca do camarão de saquinho: "Pra nóis vale o que cumeçô a usá primeiro, pro IBAMA o que manda é o registro: é mais anos de registro no lugá que é... é o dono" (Delso, 40 anos, pescador artesanal). A primeira parte da frase ('Pra nóis vale o que cumeçô a usá primeiro...') remete a uma variação da regra do "quem chega primeiro", que permeia todas as safras independente da incidência de qualquer legislação: a pessoa que iniciou a pesca de saquinho em determinado lugar e mantém seu uso no decorrer dos anos; a segunda frase ('...pro IBAMA o que manda é o registro...') reproduz o ponto de vista legal do marco regulatório; já a terceira ('...é mais anos de registro no lugá que é... é o dono’) representa uma apropriação do marco regulatório segundo a lógica da variação da regra do "quem chega primeiro".

No entanto, a regra do "quem chega primeiro" é apenas o primeiro requisito que confere legitimidade à posse da andana do camarão, conforme a lógica comunitária. A utilização da andana "quando dá" e "quando não dá camarão" ("Vai pescá nas andana só nas hora boa?!') é um outro requisito para a manutenção da posse.

A transmissão intergeracional da posse das andanas, por outro lado, aparentemente foi substituída pelos registros legais no IBAMA que estabelece um registro individual e não consuetudinário: "Não, hoje a andana num passa de pai pra filho, só se tivé no papel. É, mas antes desses registro ficava, né” (Sindo, 40 anos, pescador artesanal). Porém, observações de conflitos criados pelo registro por terceiros de uma andana herdada, e o consequente posicionamento da comunidade em favor dos herdeiros, permite que se ponderem os dados, como falas que reproduzem a idéia do Sindo, e se reconsidere a substituição pela INC (2004): "Se alguém registrá eu num sei

\footnotetext{
${ }^{267}$ Oficialmente, o local registrado onde se coloca o "aviãozinho" é chamado de "andaina", enquanto os coreanos a chamam de "andanas".

268 A rede de espera para pesca do camarão, chamada oficialmente de "aviãozinho", é mais frequentemente chamada de "saquinho" pelos pescadores da Coréia.
} 
o que acontece... num sei, acho que a tendência é... acho que pros filho. Deve sê, né” (Delso, 40 anos, pescador artesanal). O registro legal de andana desarticula uma outrora inquestionável transmissão das andanas do pai para os filhos e gera uma tendência de se transmitir as andanas para a prole do sexo masculino, o que constitui um outro requisito para a posse de andanas.

A apropriação da andana de camarão se dá por um pescador apenas ('A gente trabalha sozinho'). Somente quando há filhos aprendizes ou quando um pescador está "atrasado", e há alguém por perto com laços de afinidade, é que mais de uma pessoa trabalha em uma "andana". No entanto, em ambos os casos, os ajudantes trabalham precipuamente com o pescador dono da "andana".

Curiosamente, o marco legal da INC (2004) que define os limites ('bordas') entre as andanas, ou seja, o espaço mínino lateral de 50m ('andainas de mesmo alinhamento') e frontal de 300m entre as andanas, é incorporado às tradições pesqueiras, embora com maior flexibilidade ${ }^{269}$. A delimitação da andana torna possível a apropriação de um determinado "trecho de água" em que os recursos disponíveis podem ser capturados pelas redes posicionadas "na enchente" ou "na vazante" e "de boca pra terra" ou "de boca pra fora" de acordo com a dinâmica ambiental, como foi visto no item 4.4.2.1, em "anos de água salgada" e "de água misturada”. Portanto, a INC (2004) é incorporada e define os limites de posse de uma andana, já que permite a reprodução social a partir da lógica do conhecimento ecológico tradicional.

Segundo Michel de Certeau (1996), esta reapropriação pela cultura popular do espaço organizado por estruturas tecnocráticas na forma de leis, constitui uma das "mil formas" de se alterar as leis ('metamorfoses da lei'), de acordo com seus interesses próprios e suas próprias regras. O que está em jogo é um 'ratio popular', ou seja, uma maneira de pensar investida numa maneira de agir. Neste sentido, a construção de andanas de camarão na Coréia se dá pela reapropriação da INC (2004) através do conhecimento ecológico tradicional e de regras próprias de posse e de delimitação territorial que, por sua vez, são os principais mecanismos de apropriação das unidades básicas do espaço marítimo segundo Cordell (1989), os pesqueiros. Portanto, as “andanas" de camarão são pesqueiros construídos através da lógica das tradições pesqueiras coreanas. Cardoso (2001) e Almudi et al (2004) pontuam que a pesca no Rio

\footnotetext{
${ }^{269}$ A abertura lateral é chamada pelos pescadores da Coréia de "porteira" e serve para a passagem de embarcações.
} 
Grande do Sul com "aviãozinho" representa uma forma de apropriação do espaço aquático na construção de territórios que pode ser individual ou em grupo.

Apesar da política do IBAMA de imobilizar o pescador em uma andana durante toda a safra, há uma intensa movimentação dos pescadores pela procura de outros pontos de pesca quando a andana registrada não está proporcionando boas $\operatorname{pescarias}^{270}$ :

E antão eu pesco ali no Saco da Agulha. As veiz não dá ali, o cara tem que saí pra outro lado, né, tchê. O camarão não dá num lugá só, entendesse. (...). Se tem um lugá lá que não estrove o outro, tu vai botá, né, cara. Se tá dando, entendesse? Tem época que não, que dá até o fim ali naquele lugar. Mas tem outras época que não, né, tchê. O cara precisa, então vai tê que circulá, né. (Sindo, 40 anos, pescador artesanal).

Se o critério de utilidade da andana ('dá camarão') não estiver sendo atendido, o pescador vai procurar um outro ponto de pesca (' $\mathrm{O}$ cara precisa, então vai tê que circulá'), desde que este ponto de pesca não esteja no raio de incidência do pesqueiro de outro pescador ('Se tem um lugá que não estrove o outro, tu vai botá') ${ }^{271}$. Neste caso, também há uma apropriação pela lógica tradicional da legislação que incide sobre as andanas: "Geralmente que nem, o cara faz o registro de andana, o cara registra uma andana, mas o negócio o seguinte: tu não pesca até o fim naquele lugar. O camarão dá um tempo ali depois ele não dá mais, né, cara. E aí vai ficá parado só por causa que é registrada?" (Sindo, 40 anos, pescador artesanal). Como pode ser visto, as regras legais de posse só mantém sua viabilidade enquanto também atende ao critério cunhado pela lógica das regras tradicionais (informais): "dá camarão".

Esta intensa movimentação do pescador no contexto de domínio de pesca de saquinho por andana fixa gera uma tensão entre duas categorias de pescadores, o "pescador parado" e o "andarilho"272 273 , quanto à movimentação dos “andarilhos" entre as andanas dos "pescador parado":

\footnotetext{
270 Os novos pontos de pesca apropriados informal e momentaneamente pelos "andarilhos" não necessariamente serão próximos às residências dos pescadores como é a tendência observada para as andanas formais.

271 Almudi et al (2004) também observou que a movimentação dos pescadores de saquinho durante a safra de camarão obedece a acordos informais entre eles.

${ }^{272}$ Pedi que meu informante, um "pescador parado", definisse um "andarilho": "Aquele que vai atrás daquilo que é do outro. Parece umas puta, onde tem homem tão atrás, onde tem camarão, tão atrás".

273 As duas categorias de pescadores personificam mais um momento em que o pescador está fixo ou em movimentação para troca de andana do que pescadores que definitivamente são "parados" ou "andarilhos".
} 
Fulano, tu que é andarilho, tem que andá pelas porteira cara! É pra isso que existe as porteira. Num tem essa... que nem ontem: ciclano lá das vila passô panejando pano na andana de beltrano: eu toquei-le bala! Ele cuida a minha, eu cuido a dele cara! Porque tem porteira pra passá? Cum tanto lugá pra passá... por que num passa pelas ponta de terra? Andarilho tem que andá por fora das andana! (Nome não identificado a pedido do entrevistado).

O trânsito dos "andarilhos", como se pode ver, só é permitido nas "bordas" das andanas ('andarilho tem que andá por fora das andana': as 'porteiras' e as 'pontas de terra'). A inobservância desta regra por qualquer um dos pescadores possibilita que sejam confundidos com bandidos. Como diz um ditado local: “À noite todos os gatos são pardos".

Um outro problema gerado pela troca de andana durante a safra é quanto ao critério para a manutenção de posse da andana. Com ou sem registro, quando um ponto de pesca é apropriado por um pescador e sua posse reconhecida, criando as andanas, há o respeito entre os comunitários: “A minha andana é bem aqui assim ó: sai aqui da Ponta do Mosquito pra fora. (...). Não é registrada não, mas é ali que eu peguei duas safra grande: a de dois mil e essa agora. O pessoal respeita, fica mais ou menos certo..." (Moisés, 45 anos, pescador artesanal). Porém, para a manutenção do respeito à posse é necessário o uso recorrente: "Pra mim o que vale é a consciência da pessoa e não os papel. Se o dono da andana não usá ela desde o início da safra, perde o direito. (...). O dono não tem direito de tirá de quem tá pescando nela desde o início... Só nas hora boa?! Isso aí não é direito" (Rudinei, 30 anos, pescador-lavrador). Se o dono da andana não a utilizá-la desde o início da safra ou se fizer ausente em qualquer outro momento durante a safra ('Só nas hora boa?!'), abre precedentes para o uso por outro pescador, o que quase sempre gera conflitos.

Uma solução gerada intracomunitariamente para diminuir os conflitos em torno destas andanas são relações de cooperação como o empréstimo de andana: "A gente pega até andana emprestada um do outro que as veiz tem cara que num tá pescando na andana, vai pra outro lugá, né. As veiz acontece isso também” (Delso, 40 anos, pescador artesanal). Um possível interessado no uso da andana pede-a emprestada ao seu dono que quase sempre consente, mesmo que não haja afinidade entre eles ('Já emprestei pra cara que é meu inimigo...' Sr. Zezinho, 60 anos, pescador-lavrador). Se por ventura o dono da andana quiser retornar a usá-la ele precisa cumprir uma regra: “Aí quando o cara volta, ele avisa um dia ou dois antes. Aí o cara tira e bota no outro lado. É pra dá um tempo pro cara botá em outro lugá, né" (Delso, 40 anos, pescador artesanal). Para 
retornar o dono de uma andana precisa avisar o atual usuário com algum tempo de antecedência, no mínimo um dia, para que ele tenha tempo de procurar um outro ponto de pesca.

Dentro da categoria "andarilhos" incluem-se também os que pescam camarão com artes de pesca móveis. Entretanto, neste caso a tensão se dá entre os que pescam com artes de pesca fixa, incluindo os andarilhos que trocam de andana, e os que pescam com artes de pesca móveis ${ }^{274}$. A "plancha", pesca de arrasto a motor, tem seu uso condenado em qualquer parte do "nosso mar" no "inverno" ou no "verão", e não apenas durante a safra de camarão, sobretudo no Saco do Boto, no Saco da Pinguela e dentro dos limites das "andanas". O "berimbau" (rede de arrasto manual) é veementemente condenado apenas dentro dos limites ou nas bordas das "andanas". Em caso de desrepeito a esta regra e houver arrasto de "plancha" ou de "berimbau" dentro dos limites ou nas bordas de uma "andana" pode haver confrontos armados. Para evitar tais confrontos, duas estratégias são adotadas para a manutenção da posse dos recursos da andana: o segredo sobre o sucesso na pescaria através de difusão de "informações específicas" contraditórias ("Eu mesmo, as veiz, eu matava camarão lá no Mosquito, o pessoal indagava. Eu: 'Não, eu matei em tal lugar"' Sr. Dino, 67 anos, pescador artesanal) e armadilhas contra redes de arrasto como "tocos" (de taquara), arame farpado e até cacos de vidros enterrados no entorno da "andana".

Diferente das outras pescas de arrasto, a pesca de "coca" (rede de arrasto manual) dentro dos limites ou nas bordas da andana é permitido: “A coca faz uma água suja, alevanta o camarão. A coca é uma pescaria antiga, num destrói nada... inté pelo contrário. Se arrastá na volta das rede ('saquinho') é bom pra pescaria" (Guega, pescador artesanal, 54 anos). Devido ao uso da coca "alevantá o camarão" que está enterrado, aumentando as possibilidades de sua pesca pelas redes de saquinho, segundo os pescadores da Coréia não há necessidade da proteção dos recursos contra a coca.

A desarticulação da ética do respeito cria um clima tenso também entre os "pescadores parados" através da apropriação de uma andana já usada por outro: "As veiz chega cara de fora aí que, a gente, as veiz, tira e bota o saquinho. Eles chegam e botam mesmo. Aí tu tem que í lá pra chamá pra tirá. Tem cara que é teimoso, né, num

\footnotetext{
${ }^{274}$ Além da coca, cujo processo de tomada de decisão foi discutido no item 4.4.2.1, outras artes de pesca móveis são utilizadas na Coréia. No entanto, são artes condenadas por eles mesmos e, por isso, não utilizadas muito frequentemente. Os conflitos com estas artes de pesca explodem devido ao uso mais disseminado entre os pescadores "das vila" que vão pescar nas águas da Coréia.
} 
qué tirá. Aí dá rolo" (Delso, 40 anos, pescador artesanal). Sobretudo, com pescadores de outras comunidades de pesca ('As veiz chega cara de fora aí...') pode acontecer de ele se apropriar de uma andana ('Eles chegam e botam mesmo...') por não ter rede marcando o uso da andana ('...a gente, as veiz, tira e bota o saquinho...'), o que pode gerar conflitos, inclusive armados ('Tem cara que é teimoso, né, num qué tirá. Aí dá rolo'). Há também o registro no IBAMA de uma andana por um pescador, informalmente ela já era usada por um outro pescador: "Já aconteceu de gente aí registrá as andana dos outro..." (Delso, 40 anos, pescador artesanal), o que pode levar a brigas no mar e em terra e até a confrontos armados. Neste caso, a comunidade respeita "quem chegô primeiro".

Há, ainda, o aumento de uma andana pela apropriação de suas bordas:

Tem muitos dia aqui na Agulha mesmo se tu sai lá do Canto da Agulha pra cá, se tu não soubé o caminho tu (...) vai tê que tá socando de andana e andana pra achá a porteira da rede e as veiz os cara não deixa, né, num deixa porteira. Chega ali muitos colocam uma manguinha pra puxá pra ele. (Moisés, 45 anos, pescador artesanal).

Muitas vezes ocorre de um pescador se apropriar das regiões de borda da andana ('...os cara não deixa, num deixa porteira. Chega ali, muitos coloca uma manguinha pra puxá pra ele'), o que pode gerar conflitos com outros pescadores que tem andana próximo aos limites apropriados. Em campo foi observado que este é um dos principais conflitos entre os "pescadores parados", sendo a presença constante do pescador em sua andana e a de marcos (redes e/ou 'taquara') indicando o seu uso estratégias adotadas para se evitar conflitos e manter a posse.

A desarticulação da ética do respeito também ocorre através do roubo de redes, de pescado e de taquara da andana:

E num existia roubo também. Pudias botá uma rede e í embora, (...) ela ficava trêis-quatro dia ali. (...). Chegava lá, se deu peixe ela tava pregada de peixe: ninguém te pegava um peixe, ninguém pegava uma rede, nem nada. (...). E hoje não, hoje tu botas rede, se dé as costa deitá e durmí, num tem mais rede nenhuma. Já levaro tudo! (Sr. Meca, 68 anos, pescador-lavrador).

O pessoal do Prado é terrível no roubo de taquara, eles num têm taquara lá no bairro deles. (Gordo, 39 anos, pescador artesanal).

O surgimento da desarticulação da ética do respeito através dos roubos é atribuído aos "das vila": "Aquela gente do Prado, Bosque, daquelas vila ali é terrível" 
(Sr. Rui, 60 anos, pescador artesanal). Apesar dos roubos serem uma característica atribuída aos "das vila", algumas vezes o roubo de taquaras é uma prática atribuída a membros da comunidade, os "andarilhos": "Pilhando as taquara das andana dos outro?! Assim é fácil trocá de andana toda hora” (Milson, 26 anos, pescador artesanal).

Uma solução adotada por alguns pescadores para manter a posse dos petrechos de pesca, dos pescados e das taquaras e, consequentemente, do pesqueiro é a vigia das redes pelo próprio pescador dono do pesqueiro. Há algumas variações desta solução, a vigia de um pesqueiro pode ocorrer por cooperação de algum outro pescador de confiança que esteja pescando por perto e/ou pode ser simulada colocando-se o bote, sem ninguém, próximo às redes ${ }^{275}$. Neste sentido, as variações da vigia da rede pelo próprio pescador estão imbuídas da ética do segredo. A solução, e suas variações, é parcial, pois a prática da pesca do camarão se dá predominantemente a noite e alguns roubos ocorrem durante o dia ${ }^{276}$, embora com menor frequência.

"Aqui dentro" há a desarticulação do respeito por grande quantidade de rede. Quando alguns pescadores são proprietários de grande quantidade de rede, por consequência se apropriam de grandes trechos de água, ou seja, um grande pesqueiro é possuído por apenas uma pessoa, o que resulta na distribuição desigual dos recursos: “Esse nosso mar aí num cabe mais rede. (...). É muita rede... tem gente aí pescando cum quarenta rede" (Sr. Rui, 60 anos, pescador artesanal). Neste sentido, a desarticulação da ética do respeito se dá pela inoperância de um princípio básico da posse no mar: a alocação de recursos. Segundo Thornton (1980) o território de um grupo é, antes de tudo, um espaço dividido. Complementarmente, Cordell (1989) aponta que estas divisões do território em pesqueiros, no caso da pesca, é uma das principais funções do sistema de posse no mar: a alocação de recursos. Portanto, a apropriação de um grande "trecho de água" e, consequentemente, de camarão por uma quantidade desproporcionalmente maior de redes gera conflitos dentro da comunidade com base na desarticulação da ética do respeito à posse no mar.

Uma outra estratégia de competição é a difusão de "informações genéricas" contraditórias (“Hoje eu pesquei mais camarão na vazante, mas a água tava enchendo... camarão num tem dessa, né, ô. Que nem diz o outro: 'camarão num dá de intendê, só

\footnotetext{
${ }^{275}$ A simulação, que geralmente ocorre próximo à residência do pescador, abre a possibilidade para um risco ainda maior. Se descoberta pelos "ladrões", o pescador perde não só as redes, mas também o bote. ${ }^{276}$ Como a pesca na Coréia é predominantemente noturna, durante o dia as redes ficam "pro alto" ou "erguidas", ou seja, ficam amarradas às taquaras fora d'água.
} 
tem merda na cabeça" " Guega, 54 anos, pescador artesanal) ${ }^{277}$. Neste caso, a prática da ética do segredo através das "informações genéricas" contraditórias visa esconder dos outros pescadores "parados" a "feição" da rede que está pescando mais camarão, enchente ou vazante, em referência aos "sinais de memória" que foram discutidos no item 4.4.2.1. Por outro lado, quando há um "sinal de memória" que indica uma importante mudança de fase na dinâmica ambiental (represos, chuvas intensas, frio, etc.) e não variações ambientais cotidianas (se o camarão 'tá dando na enchente' ou 'na vazante'), as informações são compartilhadas ('O camarão agora é de entrada, ele vem na ponta d'água' Sr. Ivo, 66 anos, pescador artesanal aposentado) contribuindo para que o grupo se situe no momento de cada safra.

A causa da existência de uma intensa competição geradora de todas as situações de conflito descritas acima na pesca de camarão com andana, é devido ao grande aumento de pessoas nesta pesca: "Nesse tempo era pouco pescadore e muito bixo, hoje é mais pescador do que camarão" (Guega, 54 anos, pescador artesanal). Em outros estudos realizados em outras regiões do Brasil, como Begossi (2000), e no estuário da Lagoa dos Patos, como em Almudi et al (2004), também indicaram o grande número de pescadores como uma das causas de uma competição intensa. Alguns problemas gerados por esta competição, como foi visto, encontram soluções intracomunitárias com premissas no respeito à posse da andana (como o empréstimo de andana e as informações contraditórias), embora outras soluções para a manutenção da posse ('tocos', arame farpado e caco de vidro no entorno da andana) advém da deterioração da ética do respeito. Vale ressaltar, no entanto, que a deterioração da ética do respeito ocorre na relação dos coreanos com os "de fora", sobretudo com os pescadores “das vila” ('Lá nas vila num tem um só que presta...' - Sr. Zezinho, 60 anos, pescador-lavrador). Neste sentido, pode-se considerar que a competição durante a safra do camarão entre os coreanos e os "da vila" está consoante ao que Cordell (1983) chamou de "competição espacial destrutiva".

Algumas situações de risco suspendem o rigor das regras de posse da andana e permitem a presença dentro de seus limites e o seu uso por um outro pescador. Vários relatos de pescadores que tiveram seus botes encalhados nas "croas", devido a situações

\footnotetext{
${ }^{277}$ Foram observados vários casos em que o pescador pesca maior quantidade de camarão na enchente e diz que pescou maior quantidade na vazante e vice-versa. Nesta fala citada acima, foi observado que o pescador tinha pescado a maior quantidade de camarão na enchente.
} 
de regimes de vazante inesperados, e ficaram presos sem água potável e alimentos, puderam retirar taquaras e pescados das redes de "andanas" alheias sem aviso prévio.

Já a construção da posse dos pesqueiros com artes de pesca móveis se dá de forma diversa da pesca com redes fixas em andana. Tanto em "ano de água salgada" quanto "de água misturada", o conhecimento ecológico tradicional da migração do camarão associado a hidrodinâmica embasa a procura e a escolha de locais para a pesca de coca, uma rede de arrasto manual, conforme foi visto em 4.4.2.1. O conhecimento ecológico tradicional associado a técnica de pesca engendra as regras de posse na apropriação de um pesqueiro: “...viemo terminá de arrastá ele aqui no clareá do dia aqui no junco do Neves. Ali ele se enterrô, (...). Então eu falei pro meu companheiro (...): 'vamo esperá esse louco se levantá. Quando levantá com o entrá do sol nóis vamo tá aqui"' (Guega, 54 anos, pescador artesanal). O lugar onde o camarão se enterrou ('junco do Neves') é apropriado pelas duas pessoas que pescam juntas com a rede de coca ('com o entrá do sol nóis vamo tá aqui') através da regra de "quem chega primeiro".

Como o pesqueiro apropriado pela rede de coca não é registrado como é a andana, a manutenção da posse se dá pelo segredo:

\footnotetext{
Nóis bota mesmo é pra se escondê. As veiz a gente fazendo assim escapa duas ou três volta. Depois eles pegam, o pescadô é em muitos lado. Tudo qué se defendê. Na época que eu fazia sombra era coca, era coca que eu trabalhava. Depois, um dia, no que olhemo assim chegô um, (...), disse: 'Ah, te peguei', eu tava matando bastante camarão, né, tinha bastante, 'Achei vocês'. Eu digo: 'Ah, eu num tava se escondendo'. Ele disse: 'Ah, pra quê essa lata atrás do lampião?'. Eu disse: 'Ah, é pra nóis não incandiá na luz'. Ele disse: 'Ah, não, não, não, vocês tavam se escondendo'. (Sr. Rui, pescador artesanal, 60 anos).
}

No entanto, muitas vezes o pesqueiro é descoberto por outros pescadores, o que não abole o pesqueiro na presença de "quem chegou primeiro", mas o circunscreve aos limites da rede ('Muitas veiz eu tava pescando camarão e o Delamar passava arrastando do meu lado... eu ia e ele vinha' - Sr. Dino, 67 anos, pescador artesanal). A constatação da existência de pesqueiros com técnicas de pesca móveis contraria o que Almudi et al (2004) concluiu sobre a territorialidade no estuário da Lagoa dos Patos para a pesca do camarão: não há territórios para as técnicas de pesca móveis.

No iten 4.4.1.1 e 4.4.2.1, através do conhecimento ecológico tradicional é descrito o movimento migratório do "camarão de arriada", em "ano de água salgada" ou "de água misturada", na direção N-S do estuário e do "canal pro baixo" que embasa a 
posição das redes de saquinho somente "embocado na vazante" na "Ponta do Mosquito", ou seja, "ali fora". Ao conhecimento ecológico tradicional e à posição das redes se engendra as regras de posse na apropriação de um pesqueiro:

A minha andana é bem aqui assim ó: sai aqui da Ponta do Mosquito pra fora. (...). Não é registrada não, mas é ali que eu peguei duas safra grande: a de dois mil e essa agora. $\mathrm{O}$ pessoal respeita, fica mais ou menos certo... eu acho. E é que nem aqui dentro: trezentos metro uma da outra. (Moisés, 45 anos, pescador artesanal).

Para a apropriação de um pesqueiro são três mecanismos de apropriação: o conhecimento ecológico tradicional (movimento migratório associado a hidrodinâmica para o posicionamento das redes), a variação da regra de "quem chega primeiro" ("Não é registrada não, mas é ali que eu peguei duas safra grande [...]. O pessoal respeita...') e a delimitação do pesqueiro ('E é que nem aqui dentro: trezentos metro uma da outra'). Portanto, também "ali fora" a posse de um pesqueiro também se dá pela mesma lógica de reapropriação da INC (2004) para a andana "aqui dentro".

A apropriação do pesqueiro "ali fora", ou seja, nas bordas do território grupal coreano, como "aqui dentro", ocorre individualmente e há desarticulação da ética do respeito aos pesqueiros. É por isso que o Moisés diz “O pessoal respeita, fica mais ou menos certo... eu acho".

Um conjunto de relações sociais foi criado para a manutenção da posse frente ao ambiente social considerado hostil ${ }^{278}$ e para responder a eventuais conflitos. Ainda em terra ocorre uma intensa troca de informações sobre a situação da pesca na "Ponta do Mosquito" (quem está pescando 'ali fora', se há quantidade 'boa' de pescado, 'monção' de tempo para ir, etc.). A intenção é angariar companhias, mesmo que autônomos entre si e em "botes" diferentes, e estabelecerem-se em um só grupo na "Ponta do Mosquito". A partir do momento em que cada pescador "bota as rede", há mútua proteção das andanas. Em caso de conflito com algum pescador de outra comunidade, há possibilidade de mediação por algum pescador da Coréia com quem compartilha dos mesmos códigos sociais, já que "lá fora" há um mosaico de bagagens de relações sociais pesqueiras devido à co-existência de diferentes comunidades. Ao retornar "aqui pra dentro" é frequente a formação de "comboios".

\footnotetext{
${ }^{278}$ No item 4.1 foi discutida a representação do "Lá fora" como um local em que as relações sociais e as forçantes ambientais são consideradas hostís.
} 
"Lá fora" também há a desarticulação do respeito por grande quantidade de rede e que traz reflexos na apropriação de pesqueiros em território coreano:

\begin{abstract}
Hoje vai por fora é só saquinho, saco e saquinho, saco e saquinho... vão devastando ele! Basta que o camarão dá mais lá pra cima, aqui pra baixo num dá quase. Por quê? Porque ele morre todo lá pra cima. Esse ano mesmo, eles num mataro todo ele na lagoa? Mataro! É só lá (na Lagoa) que deu, aqui não. Só que lá eles mato que é a primeira frente, né, pego na frente e vão matando, ele vai vindo ele vai morrendo, vai diminuindo, vai diminuindo... quando chega aqui num dá nada. (...). Aquilo tudo matando comé que o camarão passa? Num tem... aqui pra baixo num deu nada, aqui pra cá menos ainda porque num tinha mesmo. E assim a pesca vai se treminá: (...) um mundaréu cum setecentas rede, cento e tantas rede. (Sr. Dino, 67 anos, pescador artesanal).
\end{abstract}

O uso de grande quantidade de redes por alguns pescadores de outras comunidades que exercem suas atividades "lá pra cima” ('Hoje vai por fora é só saquinho, saco e saquinho, saco e saquinho... vão devastando ele! [...]. E assim a pesca vai se treminá: (...) um mundaréu cum setecentas rede, cento e tantas rede') e "ali fora" ('A gente vai ali na Ponta do Mosquito e olha pra Torotama até arrepia de vê tanta rede') impede que o camarão complete sua migração reprodutiva do estuário para o oceano e, por isso, dificulta a pesca dos coreanos em suas andanas "ali fora” ('Só que lá eles mato que é a primeira frente, né, pego na frente e vão matando, ele vai vindo ele vai morrendo, vai diminuindo, vai diminuindo... quando chega aqui num dá nada [...]. Aquilo tudo matando comé que o camarão passa? Num tem... aqui pra baixo num deu nada') e "aqui dentro" ('...aqui pra cá menos ainda porque num tinha mesmo') e torna desigual a distribuição dos recursos entre as comunidades ('Basta que o camarão dá mais lá pra cima, aqui pra baixo num dá quase. Por quê? Porque ele morre todo lá pra cima').

"Lá fora", assim como "Aqui dentro", a desarticulação da ética do respeito se dá pela inoperância do que Cordell (1989) considera uma das principais funções do sistema de posse no mar: a alocação de recursos. Os recursos a serem apropriados, segundo Begossi (2004), devem ser suficientes para compensar os custos para manutenção dos pesqueiros, o que o quinhão destinadado à Coréia para a manutenção dos pesqueiros de camarão "ali fora” parece efetuar com dificuldade ('...vai morrendo, vai diminuindo, vai diminuindo... quando chega aqui num dá nada').

Uma solução encontrada por alguns pescadores que indica uma tendência de ação mediante a alocação desigual dos recursos, sobretudo pelos coreanos a oeste da 
croa dos cavalos, é não ir mais pescar "ali fora" ('Não paga a pena í pro camarão ali'). Como consequência da dificuldade de fundação e manutenção de pesqueiros "ali fora", além da emergência de relações sociais a partir dos pontos de pesca, numa escala comunitária de análise, o movimento de expansão territorial do grupo para as bordas, atrelados à migração reprodutiva do camarão, se enfraquece. São as saídas durante o "verão" para a "Ponta do Mosquito" que ocorrem por um número de pescadores cada vez menor, sendo quase todos do leste coreano.

É devido à dificuldade de manutenção dos pesqueiros que os conflitos com pescadores que pescam em regiões distantes podem ser considerados territoriais.

A prática do segredo, seja com artes de pesca fixa ou móvel, "aqui dentro" ou "ali fora", frequentemente é desarticulada pelos atravessadores que disseminam indiscriminadamente informações sobre quem pescou mais, onde e o tamanho do camarão. Todas as manhãs há uma atualização das informações sobre as boas pescarias. Por isso, no dia seguinte de boas pescarias em determinada "andana", não é incomum se observar pescadores de "berimbau" arrastarem "na volta" (no entorno) daquela "andana".

Em "ano de água salgada" a perspectiva é "ruim" para a safra de camarão no "nosso mar" e "boas" para "lá fora", conforme foi visto no item 4.4.1.1.1. A frustração de safra "aqui dentro" e notícias de melhores safras em outros locais do estuário gera uma migração dos coreanos a procura de melhores pontos de pesca em outros territórios: “Que nem esses dias mesmo: dei uma saída e fui lá na Várzea (...). Tive lá que diziam que tava dando, dando, dando... Fui lá e não era o que o pessoal dizia. Tu vê, por isso que eu te digo, né, cara, o cara precisa o cara saí, né, se aventurá". (Sindo, 40 anos, pescador artesanal). A construção de pesqueiros por coreanos em outros territórios leva, em uma análise comunitária, à expansão temporária além bordas do território nestes períodos de escassez até que uma nova safra se reinicie nas águas da Coréia (Figura 2).

Em "anos de água doce" em que a frustração de safra parece ser geral, em todo o estuário da Lagoa dos Patos, como visto no item 4.4.1.1.1, a primeira estratégia adotada é outra:

Não, eu num pesquei siri, mas o pessoal pescava. O que safô o pessoal aqui foi o siri, num tinha nada. É dentro desse banhado que o pessoal andava pescando siri. Num tinha camarão, num tinha nada. Em noventa e oito (...) eu 
acho que nóis tava pescando era tainha. É, eu num era aposentado ainda... é, era tainha. (Sr. Dino, 67 anos, pescador artesanal).

A primeira estratégia adotada em "anos de água doce" é a diversificação das espécies-alvo, sobretudo tainha e siri, procuradas em locais pouco visitados em "tempo de fartura". Os "banhados" a que o Sr. Dino se referiu é o "arroio da Pinguela", lugar considerado assombrado. É o uso em tempos de escassez de um local que é “descansado" em "tempos de fartura" (Figura 2).

A partir do momento em que a diversificação da pesca já não é possível "aqui dentro", ocorre a diversificação da pesca em outros territórios: "Naquele ano do El Niño mesmo eu num saía de lá da Pinguela (...). Já cansei de í daqui ao Pesqueiro também, atravessá direto daqui ao pesqueiro, atrás de tainha, traíra quando tinha muita água doce pra cima á" (Amarildo, 40 anos, pescador artesanal). A fundação de pesqueiros em outros territórios, como a comunidade do "Pesqueiro" (Figura 1), implica, numa escala comunitária, na expansão temporária das bordas do território coreano até que se reinicie uma nova safra nas águas da Coréia.

\subsubsection{A tainha}

$\mathrm{Na}$ a pesca da tainha, a Coréia dispõe de duas técnicas de pesca: a rede de menjoada e de lance, sendo a primeira uma arte de pesca fixa (rede de emalhar de espera) e a segunda móvel (rede de cerco móvel).

Em qualquer categoria de "verão" e "inverno" ocorre a pesca de tainha de menjoada "aqui dentro", como foi visto nos itens 4.4.2.2 e 4.4.2.3. Foi visto também nestes dois itens que, segundo o conhecimento ecológico tradicional do comportamento migratório da tainha "lameirão"-“croa" e da alta mobilidade da tainha, as redes são colocadas tanto "ao correr" quanto "atravessado", inclusive das duas formas ao mesmo tempo $^{279}$ ('saltiado'). A apropriação do pesqueiro se dá por um pescador. A partir disso, em geral, é permitido a um segundo pescador colocar redes próximas às de um pescador que chegou primeiro a um pesqueiro, inclusive na frente das redes já postas, tanto "ao correr" quanto "atravessado": "Tainha também tem essa aqui: muda muito. Podes botá

\footnotetext{
${ }^{279}$ A posição das redes não faz diferença também por que uma das pontas da rede é solta ficando a mercê dos ventos e da correnteza.
} 
rede (...), tu chegá ali do meu lado e botá rede que eu num posso nem abri a boca. (...) a tainha pode botá: quem tem pescaria na cabeça não reclama. É até bom..." (Moisés, 43 anos, pescador artesanal). Neste caso, semelhante à construção do pesqueiro de um petrecho móvel, a posse do pesqueiro é restrita aos limites físicos da rede, ainda que esta seja uma pesca com rede de espera. Quando não há laços de afinidade entre os pescadores, no entanto, foram observados alguns casos em que o pescador que chegou por último evita colocar suas redes próximas à daquele que chegou primeiro procurando um outro lugar. Isto mostra certa incidência da regra do "quem chega primeiro" também na pesca da tainha, apesar de flexível, devido à forma de apropriação do comportamento do "peixe".

Para a tainha de menjoada "Aqui dentro" foi observado algumas vezes a quebra da ética do segredo através de difusão de informações: "Esse lameirão da agulha, de manhã, ele chega a rusná de tanta tainha" (Gilson, 56 anos, pescador-lavrador) ${ }^{280}$. O enfraquecimento da ética do segredo nesta pesca deve-se ao "É até bom..." ter redes de outros pescadores próximo porque "Tendo bastante rede, numa ou noutra ela se atira" (Sr. Dino, 67 anos, pescador artesanal). Neste sentido, a ética do segredo, algumas vezes, é substituída por uma relação de cooperação na construção do pesqueiro, pois tanto quanto ou até mais do que o segredo ela oferece possibilidade de otimizá-lo.

A desarticulação da ética do respeito ocorre através do roubo de redes pelos “das vila": "Roubam, se tu deixá as rede no mar aí sozinha eles roubam. É essa gente aí do Prado, Bosque, dessas vila aí. Depois que roubaram minhas rede de tainha..." (Sr. Rui, 60 anos, pescador artesanal). Uma solução adotada por alguns pescadores para manter a posse dos petrechos de pesca e, consequentemente, do pesqueiro é a vigia das redes no "mar" pelo pescador "dono" do pesqueiro.

Conforme foi visto no item 4.4.2.2 e 4.4.2.3, o lance de tainha ocorre em todas as categorias de "verão" e de "inverno" e é formado pela indução da migração da tainha da "croa" para o "fundo" que é impedida a partir do momento em que se "emboca a rede pra croa" e se fecha o lance. A partir daí, ocorre a posse da área ocupada pelo lance através da regra do "quem chega primeiro":

Aí lanceasse... eles chegam e já vão em cima de ti! Vão em cima da rede! É uns cumendo os outros. Passam atravessado e passam pra cá e passam pra lá.

\footnotetext{
${ }^{280}$ Esta e outras informações que se suspeitou ser informações falsas na pesca de "tainha de menjoada" foram confirmadas acompanhando outros pescadores na pesca nos locais divulgados.
} 
Tua rede vai pro fundo até. E outra coisa: na hora de culhê, o peixe que tivé na mão aqui (no meu lance) já vem pra cá, ó, pra embarcação deles. Num tem mais respeito, num tem mais! (Moisés, 45 anos, pescador artesanal) ${ }^{281}$.

Na narrativa do Moisés sobre um fato ocorrido "lá fora" ilustra as regras de posse envolvidas no lance: a regra de "quem chega primeiro" ("Aí lanceasse... eles chegam e já vão em cima de ti!'), a delimitação do pesqueiro ('Vão em cima da rede! (...). Tua rede vai pro fundo até') e a posse pelos recursos no interior do lance ('o peixe que tivé na mão aqui [no meu lance] já vem pra cá, ó, pra embarcação deles’). Portanto, o pesqueiro é construído e circunscrito à área ocupada pelo lance e, ao "culhê as rede", ele é lentamente descontruído e, por fim, abolido.

A apropriação do pesqueiro se dá pela "parelha"282 de lance que é constituída de duas a três pessoas (um 'patrão' e um ou dois 'proeiros') do núcleo familiar e/ou com estreitos laços de afinidade. Em qualquer um dos casos, a difusão de informações fíca restrita ao(s) núcleo(s) familiar(es) participante(s) para a manutenção da posse do pesqueiro para a "parelha" mesmo após as redes terem sido retiradas. Neste sentido, a ética do segredo se configura não apenas como uma relação de competição/exclusão com os "de fora" da "parelha", mas também de cooperação na medida em que ajuda a manter a unidade da "parelha",283.

Nos itens 4.4.2.2 e 4.4.2.3, através do conhecimento ecológico tradicional é descrito o movimento migratório da "tainha de corrida", somente em "verão de água salgada" e "de água misturada", na direção N-S do estuário e do "canal pro baixo" que embasa a posição das redes de menjoada "atravessado" e "na beira da croa do Diamante". Ao conhecimento ecológico tradicional e à posição das redes se engendra as regras de posse na apropriação de um pesqueiro: "Eu ia pra lá durante o dia. Se apertava, de um jeito ou de outro eu arrumava lá. Pô, cheguei já tinha uma pilha de gente lá! Pra ficá trezentos metro uma rede da outra e as porteira... foi difícil” (Gordo,

\footnotetext{
281 A desarticulação do respeito, descrita pelo Moisés, à construção do lance entre as comunidades que pescam na região de canal estuarino também foi identificada por Adomilli (2007). Segundo este mesmo autor, o ato de desrespeito ao lance é chamado de "remolho" pelas comunidades de pesca de São José do Norte (RS). Na Coréia, “Aqui dentro", não foi identificada qualquer desarticulação da ética do respeito ao lance.

282 A "parelha" de tainha é constituída pelo bote (a motor), caíco e redes de lance de tainha, além dos pescadores.

${ }^{283}$ Nenhuma outra pesca se utiliza tanto do segredo quanto a "tainha de lance" ('Onde ele pescô?! Ô, Gustavo, isso num se pregunta pra pescadô nenhum'). Isto se deve não apenas a valorização que a tainha ganha no mercado, depois do camarão e do siri a tainha é a pesca mais valorizada economicamente, mas ao significado que a pesca da tainha alcança entre os pescadores. Pescar bastante tainha de bom tamanho reforça a sua identidade e eleva sua auto-estima enquanto pescador.
} 
39 anos, pescador artesanal). O conhecimento ecológico tradicional (migração reprodutiva da tainha asssociada a forçantes hidrodinâmicas embasa o posicionamento das redes), a regra de "quem chega primeiro" ("Se apertava, de um jeto ou de outro eu arruamva lá. Pô, cheguei já tinha uma pilha de gente lá') e a delimitação do pesqueiro ('Pra ficá uns trezentos metros uma rede da outro e as porteira... foi difícil') constituem relações de posse também no pesqueiro da "tainha de corrida".

A apropriação do pesqueiro "ali fora", ou seja, nas bordas do território grupal coreano, se dá individualmente e há desarticulação da ética do respeito aos pesqueiros, o que gera conflitos: “Ali fora dá umas briga por andana que até arrepia” (Gordo, 39 anos, pescador artesanal).

Um conjunto de relações sociais foi criado para a manutenção da posse frente ao ambiente social "hostil" e para responder a eventuais conflitos. Estas relações sociais para a "tainha de corrida" são idênticas às geradas para o "camarão de arriada" (ver item 4.5.1) já que, como foi visto nos itens 4.4.2.2 e 4.4.2.3, as saídas para ambos os pescados ocorrem juntas, pescando-se primeiro tainha e depois camarão, devido ao comportamento migratório da tainha e do camarão em função dos ventos e de limitações das técnicas de pesca. Algumas vezes, os pescadores decidem pela pesca de apenas um dos recursos ('Não dá pra atendê tudo'), no entanto, as relações sociais criadas continuam sendo as mesmas daquelas do "camarão de arriada".

As grandes quantidades de redes para a pesca da "tainha de corrida" em outros territórios de pesca, distantes das águas da Coréia, também trazem reflexos para os pesqueiros nas bordas do território coreano:

\footnotetext{
Barquinho num se via dentro da Lagoa a uns anos atrás. (...). Então aquilo era criador e agora não! Agora os cara vão memo e cum umas burra de umas rede. (...). Eles num fazem barco grandão que nem as traineira, mas é uma traineirinha igualzinho. Igualzinho! Comé que vai sobrá alguma tainha pra nóis aqui? (Moisés, 45 anos, pescador artesanal).
}

As grandes quantidades de redes usadas impedem que a tainha complete sua migração reprodutiva do estuário para o oceano e, por isso, dificulta a pesca dos coreanos em suas andanas "ali fora" ("Barquinho num se via dentro da Lagoa [...]. Então aquilo era criador e agora não! Agora os cara vão memo e cum umas burra de umas rede'), o que torna desigual a distribuição dos recursos entre as comunidades ('Comé que vai sobrá alguma tainha pra nós aqui?') e dificulta a manutenção de pesqueiros “ali 
fora". Como foi visto para o camarão no item 4.5.1, a alocação desigual dos recursos, principal função do sistema de posse do mar segundo Cordell (1989), traz dificuldades de manutenção dos pesqueiros, segundo Begossi (2004).

A solução encontrada por alguns pescadores mediante a dificuldade de se manter pesqueiros na "croa do Diamante" é não ir mais pescar "ali fora" ( Não paga a pena então a gente num vai, né, ô') prolongando as relações sociais necessárias à pesca e à apropriação de pontos de pesca "Aqui dentro". Diferente da tendência dos coreanos a oeste da "croa dos Cavalos" de não ir mais pescar "ali fora" durante o "camarão de arriada", na pesca da "tainha de corrida" não ir já é um fato consolidado. Por outro lado, os coreanos do leste mantêm seu movimento de saída, embora com dificuldades ${ }^{284}$.

Os atravessadores na pesca da tainha, assim como foi visto no item 4.5.1 para a pesca do camarão, são os grandes desarticuladores da ética do segredo difundindo indiscriminadamente informações dentro e fora da comunidade sobre onde pescar. Vale ressaltar, neste caso, que a desarticulação do segredo significa a desagregação das éticas tradicionais de competição e de cooperação.

Em "tempos" de escassez para a pesca da tainha, "verão de água salgada demais", "verão de água doce" e/ou quando o "inverno" é subsequente a um "verão ruim", ainda que o inverno tenha proporcionado "boas" pescarias, há a apropriação de pesqueiros no "nosso mar" e em outros territórios de pesca:

\begin{abstract}
A enchente de 1984-85 também foi um inverno brabo! (...) Fomo pra tainha no Pesqueiro. Nóis andava atrás de tainha, tu corria tudo, né. Aqui num tinha nada. (Amarildo, 40 anos, pescador artesanal).

Já peguemo tainha lá dentro, eu e o Mica aqui. De menjoada, cheguemo dentro do arroio da Pinguela, esparramemo ela dentro do arroio, (...). Malhô uma pilha de tainha e num contava também, né, nóis botemo mais pra traíra. (...). Uma baita mareada, o inverno também ruim, uma safra ruim de camarão e o inverno tava entrando ruim. (Gordo, 39 anos, pescador artesanal).
\end{abstract}

A apropriação de pesqueiros de tainha em locais considerados assombrados, como o "arroio da Pinguela", e em territórios de pesca que normalmente os coreanos não vão, como o "Pesqueiro", leva a uma expansão do território coreano além bordas.

\footnotetext{
${ }^{284}$ Vale pontuar que sempre existiram estes dois grupos durante a safra da "tainha de corrida": os que saíam "ali fora" e os que fícavam "aqui dentro", mesmo antes do colapso da pesca na Lagoa dos Patos. Porém estes pescadores estavam espalhados em toda a comunidade e não agrupados pela distância dos pesqueiros "ali fora".
} 
Complementarmente à expansão das bordas do território grupal, outra estratégia adotada em períodos de escassez: "No El Niño chuveu muito: (...). Aquele ano foi o ano mais brabo! Coisa horríve! Algum siri no Arroio nóis pesquemo: siri, alguma tainhota... traíra, nóis pesquemo" (Amarildo, 40 anos, pescador artesanal). A diversificação da espécie alvo na pesca é uma estratégia adaptativa a "tempos de escassez" complementar à busca de pescados em outros locais.

\subsubsection{O linguado}

Para a pesca do linguado existem duas técnicas de pesca: a rede de menjoada (rede de espera) e a "fisga" (técnica de pesca móvel). Devido, sobretudo, ao movimento migratório nictimeral do linguado ('lameirão'-'croa') associado às forçantes hidrodinâmicas conhecidas, em qualquer uma das categorias de "inverno", as redes são colocadas "ao correr" e "na beira da croa", conforme visto no item 4.4.2.4.

Ao "botá as rede", é na posição das redes e na espera pela sucessão natural do ciclo migratório do linguado do "lameirão" para a "croa" e vice-versa que se engendra a apropriação de um certo trecho d'água: "Agora, se eu tivé botando rede de linguado e tu chega por trás de mim ou por fora, já me estrovasse. Vamo se estranhá: 'Ô, pô, tô botando rede, caramba!"” (Moisés, 43 anos, pescador artesanal). Neste sentido, a apropriação do pesqueiro ocorre através de três mecanismos: conhecimento tradicional (posicionamento das redes segundo o conhecimento ecológico tradicional da migração associada a hidrodinâmica), exclusão pela regra de "quem chega primeiro" ( ‘...se eu tivé botando rede de linguado e tu chega (...) já me estrovasse') e a delimitação de um trecho de água dos dois lados da rede de menjoada ('...tu chega por trás de mim ou por fora, já me estrovasse').

A desarticulação do respeito à posse na pesca do linguado se dá de duas formas: com os roubos das redes ('Nem me fale em pescaria de linguado, é a que eu gosto mais. Ah, pô, pescaria que eu gosto! Num tô achando jeito de dá uns camarão pra fazê umas rede, me roubaro tudo. Aqui é assim: só deixaro as tralha' - Gordo, 39 anos, pescador artesanal) e com a grande quantidade de rede possuída por um só pescador ('...inclusive fulano que só ele tinha quase o mar todo de rede de linguado. Era do Prado, era tudo, entendesse' - Moisés, 45 anos, pescador artesanal). Ambas as práticas 
são atribuídas aos "das vila", embora tenham alguns pescadores da Coréia que são apontados e admitem ser donos de grande quantidade de redes.

Os roubos são considerados desarticulações do respeito à posse, pois está incluso na posse do pesqueiro o respeito à propriedade das técnicas de pesca, conforme discutido no item 4.5.1 para os roubos dos petrechos de camarão.

Já a desarticulação do respeito por grande quantidade de rede merece considerações. Quando alguns pescadores são proprietários de grande quantidade de rede, por consequência se apropriam de grandes trechos de água, ou seja, um grande pesqueiro é possuído por apenas uma pessoa (ou 'parelha'), o que resulta em falta de espaço para outros pescadores pescarem linguado ${ }^{285}$ : “Chega lá num tem lugá. Muita rede, né, e aqui dentro o lugá é pequeno. Se tu dé bobeira deu: chegas lá, vais botá a rede e num tem. Já tem outro no teu lugá" (Moisés, 45 anos, pescador artesanal). Segundo Thornton (1980) o território de um grupo é, antes de tudo, um espaço dividido. Complementarmente, Cordell (1989) aponta que estas divisões do território, no caso da pesca em pesqueiros, é uma das principais funções do sistema de posse no mar: a alocação de recursos. Portanto, a desarticulação da ética do respeito na pesca de linguado na Coréia, ocorre pela perca do direito de apropriação de um espaço para o exercício da atividade pesqueira ('...chegas lá, vais botá a rede e num tem. Já tem outro no teu lugá') que leva à inoperância de um princípio básico de posse no mar: a alocação dos recursos.

A solução encontrada entre os pescadores da Coréia para a pesca em locais distantes e para a desarticulação da ética do respeito (roubos e grande quantidade de redes) são duas, a pesca de menjoada em dupla ('Já teve anos de inverno, eu e o Evaldo, né, pescando linguado, lá no Canto da Agulha...' - Moisés, 45 anos, pescador artesanal) e a permanência de maior tempo no "mar" com formação de acampamentos:

Até a turma hoje em dia usam ficá no mar: (...) eles vão pro mar hoje, segunda-feira, e vem sábado quando tem linguado aí. Eles vão praqueles canto ali Arraial, Quitéria, Agulha... eles vão e vem sábado, tendo peixe largam no gelo e ficam lá. Aí o cara num tem despesa, né, só cumida. (...). Se calhá fica lá semana inteira: quando é sábado vem. (Airton, 45 anos, pescador artesanal).

\footnotetext{
${ }^{285}$ De todas as pescarias, a de linguado é a que utiliza maior quantidade de rede. No entanto, a situação de não se ter mais lugar para se colocar rede no "mar" acontece quando outras comunidades de pesca, como "os da vila", também vão pescar no "nosso mar".
} 
A pesca com rede de espera no linguado é a única em que a apropriação do pesqueiro ocorre com até duas pessoas ${ }^{286}$, que permanecem acampados até "a semana inteira" (cinco dias) ${ }^{287}$, sobretudo quando se vai a borda oeste do território coreano ('Eles vão praqueles canto ali Arraial, Quitéria, Agulha...').

A falta de pesqueiros piora quando um "verão ruim"288 para a pesca é sucedido por um "inverno de água doce" em que há uma relativa abundância de linguado, como foi caso do El Niño de 1998:

El Niño, o cara pra saí daqui às trêis hora num arrumava lugá mais porque era o Marambaieiro em peso, Torotama, era o pessoal daqui, (...), era do Prado, era tudo entendesse. Então 'Ó, fulano matô deiz'. 'Ah, matô deiz!?'. Tu chegava lá já tinha gente botando. (...). E no tempo do El Niño não, num tinha lugá. Se o cara demorasse a saí num tinha lugá. (Moisés, 45 anos, pescador artesanal).

O contexto de escassez em todo o estuário leva outras comunidades de pesca a procurarem pescado nas águas da Coréia ('era Marambaieiro em peso, Torotama, era o pessoal daqui, [...], era do Prado') levando à piora na situação de falta de pontos de pesca a serem apropriados para o linguado ('Se o cara demorasse a saí num tinha lugá').

Quando as duas estratégias, a menjoada em dupla e um maior tempo de permanência no mar, não são suficientes para assegurar a apropriação de algum ponto de pesca considerado "bom", a única estratégia observada, enquanto se "chuleia" o reinício do "verão", foi a dedicação à pesca de outros recursos, sobretudo o siri e a tainha.

Com a falta de lugar para se "botá rede" o segredo na pescaria de linguado é considerado importante: não foram poucas as vezes em que todos afirmavam que não tinha nada de linguado, mas sempre alguém aparecia com algum. Quando a pesca é realizada por duas pessoas, o segredo não apenas se constitui como uma relação de exclusão, como também de cooperação entre a dupla.

\footnotetext{
${ }^{286}$ Quando a pesca do linguado ocorre em dupla junta-se as redes dos dois pescadores, divide-se as despesas (comida, combustível e revezamento na utilização das embarcações) e os ganhos ('é de metade' ou 'é meio-a-meio') sem retirada de parte alguma, apesar da existência de um "patrão".

${ }^{287}$ Vale pontuar que é o pescador que passa um maior tempo no "mar" para a pesca do linguado. Isto implica que o aumento do esforço de pesca na Coréia não se aplica em decorrência do maior tempo no mar, como Pasquotto (2005) aponta para outras regiões do estuário da Lagoa dos Patos, porque as redes permanecem menos tempo no mar hoje do que "antes" em função dos roubos.

${ }^{288}$ Um "verão ruim" para a pesca na Coréia é resultado tanto do "ano de água salgada" ou "de água doce", como foi visto em todo o item 4.4.1 quando se discutiu o "tempo do verão".
} 
Já na pescaria de "linguado de fisga", o conhecimento ecológico tradicional da migração nictimeral do linguado associado às forçantes hidrodinâmicas, no cenário de "inverno que corre seco" ou "cum pouca chuva", embasa as tomadas de decisões de quando e onde pescar linguado de fisga, conforme visto no em 4.4.2.4.

Decidido ir à pesca "de fisga", a captura do linguado que está enterrado ocorre com uma ou duas pessoas, um "na popa do caíco" com uma espécie de arpão e o outro, se houver, na "proa" com o remo. Segundo Santos (2006), técnicas que mediam a relação entre o trabalho e as "dádivas da natureza" constituem um prolongamento do corpo. Neste sentido, para a pesca de linguado de fisga na Coréia, na medida em que o barco navega, o alcance do conjunto, o "caíco" e um pescador com fisga ou, se houver, dois pescadores, um com arpão e outro com remo, é que vai ditar os limites da unidade de apropriação, ou seja, a amplitude do pesqueiro. A apropriação ocorre desde que o percurso de navegação não envolva o raio de atuação de outro pesqueiro de linguado de menjoada ou de fisga ('regra de quem chega primeiro). Mesmo na aproximação de outro "caíco" na pesca "de fisga", o raio de atuação de ambos é respeitado.

A manutenção da posse se dá pela presença da unidade de apropriação do pesqueiro em um dos trechos percorridos pelo "caíco" e na ausência, se o pesqueiro for considerado "bom", a posse é mantida pelo segredo. No entanto, quando se pesca em dupla o segredo não se constitui apenas como uma relação de exclusão daqueles que não pertencem à dupla, mas de cooperação entre a dupla, pois ambos ajudam a manter recursos dos pesqueiros para trabalharem juntos.

A dinâmica da fundação e manutenção de pesqueiros "aqui dentro", "ali fora" e além bordas confere flexibilidade aos limites do território grupal de acordo com os cenários ecológicos inaugurados pelos "anos de...". A descrição desta dinâmica do território grupal é o objetivo de 4.5.4, a seguir.

\subsubsection{A dinâmica do território coletivo}

A apropriação do espaço pode ocorrer em vários "níveis" ou escalas, seja por um indivíduo ou um grupo. Porém, é decifrando a estrutura profunda, passando por 
todos os níveis de organizações, que se encontram os atores que produzem o território (RAFFESTIN, 1993). A análise do território coreano se dá em dois níveis: o território comunitário e os pesqueiros, sendo a disposição espaço-temporal da unidade fundamental de apropriação do espaço estuarino que confere limites ao território grupal coreano. Neste sentido, a análise da dinâmica do território grupal perpassa e emerge da análise da dinâmica dos pesqueiros nas águas da Coréia. Portanto, o território antes estático do item 4.1, com subsídios dos itens anteriores, será agora dotado de movimento.

No item 4.3, foi visto que o "verão", período de "águas baixas" e "salgadas", e do "inverno", "período de chuvas" e de "água cheias", são estações em que "a água guenta um bocado de tempo parada", enquanto os períodos de transição entre "verão" e “inverno" e vice-versa são os "tempos" dos represos em que "a água vem e volta pra ficá cheia (no inverno)" e em que "vão se cortando pras águas baixa do verão", respectivamente ${ }^{289}$. Mais do que um tratado geral de hidrodinâmica do "nosso mar", no item 4.4.1 imputa-se significado biológico aos cenários ecológicos dos "anos" através das corridas reprodutivas do camarão e da tainha "ali fora" e da entrada de peixe-rei e de linguado no "nosso mar" durante os "represos" do "verão" para o "inverno" e das entradas de bagre e de corvina "ali fora" e de tainha e de "casquinha" de camarão no "nosso mar" durante período em que "as água tão se cortando".

Articulando hidrodinâmica e ciclos biológicos, segundo a ordenação dos cenários ecológicos pelos nativos, os "sinais de memória" funcionam como dispositivos que irrompem a movimentação dos pescadores coreanos e a fundação e abolição de pesqueiros "aqui dentro" e/ou "ali fora" consoante à dinâmica estuarino-biológica mantendo os atuais limites do território grupal.

Com a confluência de "sinais" (Lua minguante, ventos rebojo e frio) no cenário de represos entre "verão" e "inverno", meses de abril e maio, os pescadores coreanos fundam pesqueiros de "camarão de arriada" na "Ponta do Mosquito" e do leste coreano de "tainha de corrida" na "croa do Diamante", ou seja, nas bordas do território coreano, além de manter pesqueiros de camarão e de tainha "aqui dentro". Inaugura-se um "tempo" de pesca frenético e tenso, pois as saídas "ali fora" põem o pescador coreano em contato com um ambiente natural (corpo estuarino principal) e social (outras

\footnotetext{
${ }^{289}$ Vale lembrar que estes períodos de transição são agrupados no "verão" e no "inverno" ao passo que as "safras de verão" vão se inaugurando ou se abolindo.
} 
comunidades de pesca) consideradas hostís. Neste sentido, grupos comunitários são formados para enfrentar o ambiente hostil. Cessado o tempo de vigência da confluência de "sinais" o pescador coreano retorna "aqui pra dentro" e inaugura o "inverno".

No cenário de "águas cheias" do "inverno", a baixa abundância dos recursos pesqueiros que "dá o ano todo", tainha e siri, o baixo valor comercial das "safras de inverno", linguado e peixe-rei, e a espera pela confluência de "sinais de memória", "águas cheias" ou "águas baixas e "pontas de água doce" ou "salgada", que irrompe cada pescaria torna o ritmo da fundação de pesqueiros mais lento que se caracteriza por um intento "chuliá". Por isso, a maior parte dos pescadores-lavradores se dedicam predominantemente à plantação deixando a pesca somente aos pescadores artesanais. Na procura por pontos de abundância de pescados, na pesca de linguado e na de siri frequentemente há incursões e fundação de pesqueiros na borda oeste e a permanência de vários dias no mar. Para evitar roubos de petrechos de pesca são articuladas parcerias na pesca com petrechos de espera.

No cenário de "preparação pras águas baixas do verão", entre os meses de setembro até dezembro, na espera pela não ocorrência de chuvas há a formação de pesqueiros de siri, com parcerias, e de "tainha de inverno" "aqui dentro". Com a entrada de corvina através dos "repontes" e de tainhas, de siri e de "casquinhas de camarão" com os represos, alguns coreanos do leste fundam pesqueiros de corvina nas bordas do território grupal, na "croa do Diamante", onde grupos comunitários também são formados para enfrentar o ambiente hostíl. Cessado a passagem de corvina "ali fora", os coreanos retornam "aqui pra dentro".

No cenário de "águas baixa do verão", é possível a visualização do "siri acavalado" no "costão" da Ilha dos Marinheiros onde se fundam pesqueiros de "siri de jereré", de "siri de saquinho" e o "verão" para boa parte dos coreanos. Os ventos nordeste provocam a entrada de tainha em território coreano e, a partir daí, a formação de pesqueiros de tainha "aqui dentro", inaugurando o "verão" para os especialistas na pesca de tainha. Com o aparecimento do "camarão que qué viajá", o "verão" se funda definitivamente na Coréia, inclusive entre todos os pescadores-lavradores. Mantém-se a pesca de tainha e o ritmo intenso (todos os dias) e tenso de pesca de camarão e, consequentemente, de siri até que novas saídas para a fundação de pesqueiros nas bordas do território coreano sejam ativadas pela confluência de sinais do "camarão de arriada" e da "tainha de corrida". 
Mauss (2003) e Evans-Pritchard (2007) relatam a oscilação de tamanho de um território de populações tradicionais entre diferentes estações devido às variações ambientais, que levam à escassez de recursos naturais. Entre os índios Tremembé, no Ceará, Oliveira Júnior (2003) descreve as variações da exploração do "mar de fora" e do "mar de terra" em função do vento Leste. Já os pescadores de Coqueiral, também no Ceará, segundo Forman (1970) pescam em diferentes pontos de pesca no "verão", no "inverno" e na "quaresma": na face sul e na norte do território de pesca e nas bordas da plataforma continental, respectivamente. Para os pescadores do estuário de Valência (BA), segundo Cordell (1983), os pesqueiros, e todo o conjunto de relações sociais em torno deles, característicos de cada safra, são ativados pelo ciclo de maré astronômica, pois reorganizam áreas de concentração de pescado. Segundo este mesmo autor, como consequência da ciclicidade dos recursos biológicos e das marés, tornam-se cíclicos os pesqueiros e o território grupal. Na Coréia, em resposta às flutuações hidrodinâmicobiológicas, há a manutenção dos limites do território grupal coreano através de fundação de pesqueiros "aqui dentro" durante o "ano todo" em safras que "dá o ano todo" (tainha e siri) e "aqui dentro" (camarão, peixe-rei e linguado) e "ali fora" ('camarão de arriada', 'tainha de corrida', bagre e corvina) sazonalmente, como pôde ser visto nos cenários anteriores.

No entanto, este cenário corresponde aos pesqueiros fundados em "anos de água misturada", o "padrão etnocronológico". Porém, como pôde ser visto em 4.3 e 4.4.1, há duas outras possibilidades etnocronológicas às quais se articulam os pesqueiros que se fundam a cada safra: o "ano de água doce" e o "ano de água salgada".

Em "ano de água salgada" as diferenças em relação ao "padrão" é a não fundação das safras de corvina e de bagre, devido à necessidade de "reponte", e, portanto, não há incursões e a apropriação de pesqueiros pelos coreanos do leste "ali fora". Há também a menor abundância dos outros pescados, com exceção do peixe-rei que "vem em maió quantidade" com "pontas de água salgada do oceano", que tendem a migrar "lá pra cima". Com a menor abundância, a abolição dos pesqueiros das "safras de verão" ocorre mais cedo e a fundação de pesqueiros de camarão na "Várzea", além bordas do território coreano.

Já em "anos de água doce" fundam-se apenas três safras: tainha, porém em menor abundância que nos outros "anos", e siri durante o "ano todo" e o linguado durante o "inverno cum chuva". Com a não ocorrência das outras safras, sobretudo a 
"de camarão", e, portanto, sem as bases de fundação dos pesqueiros, os recursos, na perspectiva de Cordell $(1974 ; 1989 ; 2001)$, as fronteiras territoriais se expandem temporariamente em suas bordas na busca por pontos de abundância de pescados. Porém, as saídas para o corpo estuarino principal se dão em sincronicidade diferente da do "ano de água misturada" e "salgada", já que não há corridas reprodutivas e o "peso de água doce lá pra cima" não permite a entrada de pescados do oceano. Da busca por pontos de abundância de pescados resulta a diversificação das espécies capturadas (como a traíra, tainha e siri), a fundação de pesqueiros em lugares considerados assombrados, como o "arroio da Pinguela"290, e em outros territórios, como a "outra costa", a "Várzea" e o "Pesqueiro" (Figura 1), a intensificação de laços sociais com outras comunidades de pesca para a formação de "parelhas" de pesca, "bicos" fora da atividade pesqueira e rompimento com o ritmo frenético característico do "verão". Cordell $(1983: 19,2001)$ ressalta que "quando os ganhos são poucos há cooperação entre os pescadores em terra e na água, (...). Uma das ironias da marginalidade é que ela promove inovações em ações coletivas, criatividade e adaptabilidade entre os pobres". Portanto, as possibilidades que surgem a partir da expansão das fronteiras territoriais das águas da Coréia além bordas permitem que os pescadores respondam e adaptem-se às condições ambientais desfavoráveis.

Apesar de dentro do calendário "padrão" cada safra ter seu tempo sazonal cíclico característico de ser fundado e safras de "ano todo", há outras possibilidades interanuais ('anos de...') estruturadas cognitivamente que prevêm variações nos prazos das safras e/ou a não ocorrência sazonal das safras, como pôde ser visto no item 4.4.1. Consequentemente, a fundação de pesqueiros também não é apenas sazonal e o "ano todo" ao passo que acompanha as variações interanuais dos ciclos hidrodinâmico e biológico. Em nível de território comunitário esta variação interanual gera mais uma consequência: a manutenção dos limites do território coreano através de fundação de pesqueiros "aqui dentro" durante o "ano todo" (tainha e siri) e "aqui dentro" (camarão, peixe-rei e linguado) e "ali fora" ('camarão de arriada', 'tainha de corrida', bagre e corvina) sazonalmente em "anos de água misturada" e "de água salgada" (com exceção de bagre e corvina) e a expansão do território coreano além bordas interanualmente em "anos de água doce". Esta ruptura em "anos de água doce" da dinâmica sazonal de apropriação de pesqueiros "aqui dentro" e "ali fora" resulta de condições ambientais de

\footnotetext{
${ }^{290}$ Vale ressaltar que a pesca no arroio da Pinguela não significa uma expansão, mas o uso em tempos de escassez de um local que é "descansado" em períodos de fartura.
} 
observância interanual. Em consonância, Silva (2006) conclui que a imprevisibilidade dos recursos naturais, em função de imposições dos fatores naturais, torna os pontos de pesca e, consequentemente, o território comunitário fluídos. Kaufmann (1983) observou estas variações de tamanho em territórios de pesca de acordo com as condições ambientais. Na Coréia, portanto, a dimensão do território comunitário é dotada de fluidez numa análise temporal de escala sazonal e interanual.

Por fim, diz-se que há um acoplamento co-evolutivo, mediado pelas técnicas de pesca, entre a dinâmica estuarino-biológica e territorial. Em função dos efeitos das forçantes estuarinas no movimento migratório das espécies, há uma reordenação do movimento dos pescadores atrás dos novos pesqueiros mais produtivos. Neste sentido, Rappapport (1984) postula que os homens estão ligados aos ambientes compostos por outros organismos e de substâncias não-vivas aos quais ele deve se adaptar, o que é feito a partir de suas imagens culturais da natureza. Ou seja, o homem atua de forma adaptativa na natureza a partir de cenários ecológicos que são construídos por eles próprios e que, conforme Rappapport (1984) não é apenas biológico, mas também biológico. Por analogia, etnooceanograficamente, os cenários construídos culturalmente não são apenas hidrodinâmicos, mas também biológicos. Portanto, não há uma movimentação em busca de pesqueiros em função da dinâmica estuarino-biológica, mas em função de cenários estuarino-biológicos construídos segundo o aparato cognitivo coreano e mediante os mecanismos e a lógica de uso dos petrechos. 


\section{CONSIDERAÇÕES FINAIS}

A construção do território coreano obedece à lógica de oposição binária. A partir da estruturação de categorias segundo esta lógica, há a apropriação/ordenação de um espaço aquático tridimensional e de um continuum entre os compartimentos ambientais mar-terra-céu que, portanto, perfazem uma unidade espacial.

A emergência do território coreano se dá através de um conhecimento profundo do mundo "aqui dentro", que passa a ser o "ponto central". Do "Centro do Mundo", o "nosso mar", se irradia e circunscreve o espaço conhecido, sendo os marcos físicos, que estabelecem limites entre as comunidades de pesca, fronteiras do conhecimento ecológico tradicional. Neste sentido, o "nosso mar" é um eixo/centro geográfico e uma lógica de orientação.

Segundo o conhecimento ecológico tradicional, as principais forçantes hidrodinâmicas percebidas são os ventos, as chuvas e, secundariamente, a Lua. As duas principais forçantes estuarinas são bases não apenas dos mecanismos hidrodinâmicos, mas marcam, como "sinais de memória", o ciclo estuarino percebido (etnocronologia estuarina) e biológico das espécies pescadas.

Com base nos ventos predominates se dá a divisão sazonal do tempo estuarino: "inverno", predominância do vento rebojo ('frio'), e do "verão", predominância do vento nordeste ('quente'). Associada aos ventos, a ocorrência ou não de chuvas gera três categorias de "verão" ('verão de água salgada', 'de água doce' e 'de água misturada') e duas categorias de "inverno" ('inverno que corre seco' e 'cum chuva'). As respostas do "nosso mar" às principais forçantes hidrodinâmicas em escala sazonal caracterizam o "inverno" como "tempo de águas cheias" e o "verão" como "tempo de águas baixas", assim como transições entre as duas estações: os "represos". As diversas combinações possíveis entre "verão" e "inverno" resultam em três categorias do ciclo anual: "ano de água salgada", "de água doce” e "de água misturada".

A construção do tempo coreano, no entanto, se dá pela articulação dos ciclos estuarino aos ciclos biológicos das espécies pescadas. Na verdade, é, sobretudo, o início e o fim das "safras de verão" que delimitam o "verão" e, consequentemente, o "inverno". Dos ciclos estuarinos e das "safras de verão" e "de inverno" resulta três possibilidades de calendários etnocronológicos ('ano de água salgada', de água doce' e 
'de água misturada') em que os “prazos” das safras e, consequentemente, das estações se flexibilizam. Na Coréia, a migração entre oceano/estuário e baixo estuário/cabeceira em interface com as forçantes hidrodinâmicas são as bases para os prazos estabelecidos para as safras.

Neste sentido, apesar das duas principais forçantes serem bases para a divisão sazonal do tempo e para as categorias dos "anos", é necessário que elas sejam contextualizadas num conjunto de manifestações concretas da natureza ('sinais de memória' ligados às 'safras') característicos do tempo que funda. $\mathrm{O}$ tempo é, portanto, construído.

Vale ressaltar, no entanto, que, de acordo com os anseios dos pescadores coreanos por "boas" safras (maior abundância e tamanho dos pescados), um ciclo estuarino e um calendário é tomado como o "padrão": o "ano de água misturada". Os outros dois "anos" são vistos como duas possibilidades ao padrão.

O intercalamento dos tempos (diferentes 'anos') ao longo dos anos serve como um eixo em espiral em torno do qual giram os ciclos. Consequentemente, não apenas o espaço, mas também o tempo é tridimensional.

Do ponto de vista hidrodinâmico, a ordenação e categorização dos "anos" é uma forma de manter a dinâmica ambiental dentro de um espectro normal de variação, ao mesmo tempo em que territorializa o tempo, através do espaço em movimento ('sinais de memória'). Estes "padrões" construídos das dinâmicas estuarino-biológicas do "nosso mar" visam estabelecer "cenários ecológicos" para a inserção do ser no mundo, ou seja, constituem contextos a partir e dentro dos quais se dão as tomadas de decisão e ações dos coreanos de "quando", "onde" e "como" pescar no "nosso mar".

A incidência da INC (2004), ainda que não gere mudanças nos "prazos" das três possibilidades etnocronológicas do calendário, agrega um novo elemento social em qualquer um dos cenários de pesca ('anos de...'). Neste sentido, além do teor hidrodinâmico e biológico, em cada uma das possibilidades etnocronológicas de calendário perpassa os efeitos da INC (2004) que é apropriado segundo a lógica do grupo e re-inserido no cotidiano da comunidade gerando um resultado diverso àquele proposto em lei.

O ciclo diário de pesca, unidade fundamental de tempo, se dá pelo acoplamento entre o ciclo diário de migração "croa"-"lameirão", modulado pela hidrodinâmica do 
“nosso mar", e o maquinário cognitivo dos pescadores, mediado pelas técnicas de pesca, que percebe e se apropria deste surto de atividades animais do mundo "real" como uma forma de se programar adaptativamente à sua presa. Assim, não somente quando sair para pescar, mas também se as redes devem ser colocadas na "croa" ou no "lameirão" é decidido.

Para os pescadores, o manejo das técnicas de pesca (quando, como e onde 'botá as rede') também é feito segundo o tipo de técnica de pesca e o conhecimento ecológico tradicional do ciclo migratório "croa"-"lameirão" modulado pelas forçantes hidrodinâmicas. Resulta daí que as redes fixas são colocadas na "croa" ou no "lameirão", de dia ou de noite e "atravessado" ou "ao correr" e com os petrechos móveis a captura ativa do pescado se dá na "croa" ou no "lameirão", de dia ou de noite.

Decidido quando, como e onde "botá as rede", seja fixa ou móvel, emerge um conjunto de relações sociais de cooperação e de competição na divisão e posse de pontos de pesca, que são específicos para cada pescado, mas há regras gerais. A primeira regra de apropriação é a de "quem chega primeiro" para qualquer um dos pescados e petrechos. Mesmo na pesca do camarão, em que há incidência da posse de pesqueiros pela ICN (2004), a normatização é apropriada segundo a lógica das regras tradicionais de posse.

Para a pesca com petrechos fixos e móveis, há algumas diferenças na apropriação de pesqueiros na Coréia. Enquanto para os petrechos fixos há a apropriação de um trecho de água na espera pela sucessão natural do ciclo migratório do pescado "croa"-“lameirão", para os petrechos móveis há a captura ativa do pescado em vários pontos do "nosso mar", sendo a unidade de apropriação circunscrita aos limites físicos dos petrechos. A única exceção é a pesca de tainha de menjoada (técnica de pesca fixa) em que, apesar de ocorrer em apenas um ponto do "nosso mar" e haver a espera pela sucessão migratória, o pesqueiro é circunscrito aos limites físicos dos petrechos, devido à alta mobilidade da tainha. Isto implica que, em análise na escala dos pesqueiros, a mobilidade territorial depende da mobilidade dos pesqueiros.

Entre as regras de cooperação, está a ética do respeito à posse dos pesqueiros, que inclui além da posse do ponto de pesca a das técnicas de pesca. Intracomunitariamente, em geral, a ética do respeito tem legitimidade. Já na relação entre os coreanos e outras comunidades de pesca há a desarticulação da ética do respeito através do roubo de técnicas de pesca e a alocação desigual de recursos "aqui dentro", 
pelos das vila, e "ali fora", por diversas comunidades de pesca "lá fora" com grande quantidade de rede.

O segredo e a difusão de informações na Coréia, por outro lado, podem ser consideradas relações sociais de cooperação e também de competição. O segredo e a difusão de informações contraditórias são utilizados para manter a posse de determinado pesqueiro de terceiros. No entanto, quando a unidade de apropriação é constituída por mais de um pescador, pode ser considerada uma relação de cooperação entre os membros da parelha. Ademais, para situar os membros coreanos no tempo (momentos da safra e início e término de safras) foi observada a difusão de informações corretas, assim como na pesca da "tainha de menjoada" para otimizar a captura foi observado a difusão de informações sobre "bons" pesqueiros.

Em função dos efeitos das forçantes estuarinas percebidas no movimento migratório conhecido das espécies, há uma reordenação do movimento dos pescadores em busca de novos pesqueiros mais produtivos. É esta disposição espaço-temporal da unidade fundamental de apropriação do espaço estuarino que confere os limites ao território grupal coreano. Neste sentido, os limites do território coreano são mantidos "aqui dentro" e/ou "ali fora" através da fundação de pesqueiros, segundo as respostas conhecidas do ciclo migratório de cada safra (migração oceano/estuário e baixo estuário/cabeceira) às variações sazonais nos "anos de..." e interanuais, entre os "anos de...".

Portanto, o acoplamento co-evolutivo homem/estuário se dá em função de cenários estuarino-biológicos construídos, segundo o aparato cognitivo coreano e mediante a lógica de manejo dos petrechos de pesca. 


\section{BIBLIOGRAFIA}

ACHESON, J. A., WILSON, J. A.. Order out of chaos: the case for parametric fisheries management. American Anthropologist, vol. 98, n 3, p. 579-94, 1996.

ADOMILLI, G. K. Trabalho, meio ambiente e conflito: um estudo antropológico sobre a construção da identidade social dos pescadores do Parque Nacional da Lagoa do Peixe - RS. 2002. 109 f. Dissertação (Mestrado em Antropologia Social) - Instituto de Filosofia e Ciências Humanas, Universidade Federal do Rio Grande do Sul, Porto Alegre, 2002.

Terra e Mar, do viver e do trabalhar na pesca maritima. Tempo, espaço e ambiente junto a pescadores de São José do Norte - RS. 2007. 343 f. Tese (Doutorado em Antropologia Social) - Instituto de Filosofia e Ciências Humanas, Universidade Federal do Rio Grande do Sul, Porto Alegre, 2007.

AGGIO, R. B. M. Pesca artesanal na Baía norte de Florianópolis: captura, esforço de pesca, problemática e possíveis soluções. 2008. 75 f. Monografia (Bacharelado em Ciências Biológicas) - Centro de Ciências Biológicas, Universidade Federal de Santa Catarina, Florianópolis, 2008.

AGUILERA, V. A. Atlas linguístico do Paraná. Curitiba: Secretaria de Cultura do Estado do Paraná, 1994, 411p.

ALLUT, A. G. O conhecimento dos especialistas e seu papel no desenho de novas políticas pesqueiras. In: DIEGUES, AC (org.). Etnoconservação: novos rumos para a proteção da natureza nos trópicos. São Paulo: Ed. AnnaBlume/Nupaub/Hucitec, 2000, p. 101-124.

ALMASSY JR, A. A., FONTES, R., PEREIRA, M. T., MELO, F. A. O., DOULA, S. M. Reflexões sobre a pesquisa de campo e construção do texto etnográfico. $R$. $C i$. Humanas, Viçosa (MG), vol. 2, nº 2, p. 143-7, dezembro de 2002.

ALMUDI, T. Adequação do modelo de unidade de conservação: populações humanas, convivências e conflitos nos arredores da Lagoa dos Peixes (RS). 179 f. Monografia (Graduação em Oceanologia) - Departamento de Oceanografia, Fundação Universidade Federal do Rio Grande, Rio Grande (RS), 2005.

ALMUDI, T, KALIKOSKI, D. C., CASTELLO, J. P. Territorial control as a fisheries management instrument: the case of artisanal fisheries in the esturary of Patos Lagoon, Southern Brazil. In: $4^{\text {th }}$ WORLD FISHERIES CONGRESS, Vancouver (British Columbia), Anais... outubro 2004, 15p. 
ASMUS, M. L., A planície costeira e a Lagoa dos Patos. In: SEELIGER, U; ODEBRECHT, C., CASTELlO, J. P. (eds). Os ecossistemas costeiro e marinho dos extremo sul do Brasil. Rio Grande: Ecoscientia, 1998, p. 9-12.

ÁVILA MARTINS, C. A. A história e a história local naturalizando a sociedade e socializando a natureza: um tema para apreender Rio Grande. In: ALVES, F. N., TORRES, L. H. (orgs.). A cidade do Rio Grande: estudos históricos. Rio Grande: ed. FURG/SMEC, 1995, p. 194-204.

- Indústria da pesca no Brasil: o uso do território por empresas de enlatamento de pescado. 2006. 241 f. Tese (Doutorado em Geografia) - Centro de Filosofia e Ciências Humanas, Universidade Federal de Santa Catarina, Florianópolis, 2006.

AZEVEDO, A. L. D. M. A Ilha dos três Antônios. Águeda (Portugal): Ed. Artipol, 2003.

BHABHA, H. K. O local da cultura. Belo Horizonte (MG): Ed. UFMG, 1998, 395p.

BAILEY, K. D. Methods of social research. New York: The Free Press, 1982.

BARCELLOS, B. Informe Geral sobre a pesca no Rio Grande do Sul. Editado por BRDE/CODESUL, 1966.

BARCELlOS, L. J. P., PERES, M. B., WAHLRICH, R., BARISON, M. B. Relatório sobre otimização bioeconômica dos recursos pesqueiros marinhos do Rio Grande do Sul. FURG. Museu Oceanográfico "Prof. Eliézer de C. Rios". Fundação de Amparo a Pesquisa do Estado do Rio Grande do Sul, Rio Grande: Editora da FURG, 1991, 58p.

BAREL, Y. La reproduction sociale. Paris, Anthropos, 1973 apud DIEGUES, Antônio Carlos. Pescadores, camponeses e trabalhadores do mar. São Paulo: Ed. Ática, 1983.

BARENHO, C. P. Saber local e educação ambiental: parcerias necessárias no processo de inserção da maricultura familiar na Ilha dos Marinheiros - Rio Grande/RS. 2008. 128 f. Dissertação (Mestrado em Educação Ambiental) - Programa de Pós-graducação em Educação Ambiental, Fundação Universidade do Rio Grande, 2008 .

BARROS, H. Gestão participativa de ecossistemas costeiros na Amazônia: perspectivas na busca de uma nova relação sociedade-natureza. In VIEIRA, J. P. Conservação e 
diversidade biológica e cultural em zonas costeiras: enfoques e experiências na América Latina e no Caribe. Florianópolis: APED, 2003, p. 271-276.

BEGOSSI, A. Artisanal brasilian fisheries: development of territories and acess rules. Fisheries Research, Washington (D.C), p. 2-27, 2000.

Áreas, pontos de pesca, pesqueiros e territórios na pesca artesanal. In BEGOSSI, A (org.). Ecologia de pescadores da Mata Atlântica e da Amazônia. São Paulo: Ed. Hucitec/NEPAM/NUPAUB/FAPESP, 2004, p. 223-54.

. Temporal stability in fishing spots: conservation and co-management in brasilian artisanal coastal fisheries. Ecology and Society, Campinas (SP), vol. 11, n ${ }^{\circ}$, 2006. Disponível em: http://www.ecologyandsociety.org/vol11/iss1/art5. Acesso em: 30 nov. 2006.

BENVENUTTI, C. E. Invertebrados bentônicos. In: SEELIGER, U; ODEBRECHT, C., CASTELLO, J. P. (eds). Os ecossistemas costeiro e marinho dos extremo sul do Brasil. Rio Grande: Ecoscientia, 1998, p. 47-51.

BEMVENUTI, M. A. Abundância, distribuição, reprodução e hábitos alimentatres de peixe-rei (Atherinidae) na região estuarial da Lagoa dos Patos, R.S., Brasil. 1984. 93 f. Dissertação (Mestrado em Ciências) - Departamento de Oceanografia Biológica, Fundação Universidade do Rio Grande, Rio Grande, 1984.

Abundância, distribuição e reprodução de peixes-rei (Atherinidae) na região estuarina da Lagoa dos Patos, RS, Brasil. Atlântica, Rio Grande (RS), vol. 9, $\mathrm{n}^{\mathrm{o}}$ 1, p. 5-32, 1987.

. Hábitos alimentares de peixes-rei (Atherinidae) na região estuarina da Lagoa dos Patos, RS, Brasil. Atlântica, Rio Grande (RS), vol. 12, no 1, p. 79-1022, 1990.

BENJAMIN, W. A obra de arte na era da reprodutivilidade técnica. In: BENJAMIN, W. Obras escolhidas I. São Paulo: Ed. Brasiliense, 1985, p.165-196.

. Obras escolhidas III. São Paulo: Ed. Brasiliense, 1989.

BERGSON, H. Matéria e memória. Trad. Paulo Neves da Silva. São Paulo: Martins Fontes, 1990. 
BERKES, F. Sacred ecology: traditional, ecological, knowledge and resource management. Philadelphia and London: Taylor \& Francis, 1999, 207 p.

BERKES, F, COLDING, J, FOLKE, C. Rediscovery of tradicional ecological knowledge as adaptative management. Ecological aplications, vol. 10, n ${ }^{\circ}$ 5, p. 1251$1262,2000$.

BONILHA, L. E, ASMUS, M. L. Modelo ecológico do fitoplâncton e do zooplâncton do estuário da Lagoa dos Patos, RS. Publ. Acad. Ciências do Estado de São Paulo, São Paulo (SP), vol. 87, n 1, p. 347-362, 1994.

BOSI, E. O tempo vivo da memória: ensaios de psicologia social. São Paulo: Ateliê Editorial, 2004, 220 p.

Memória e sociedade: lembranças de velhos. São Paulo: Biblioteca de Letras e Ciências Humanas, 1979.

BRANDÃO, C. R. Memória Sertão. São Paulo: Ed. Cone Sul/UNIUBE, 1998. 312 p.

BRUNI, J. C. Uma introdução ao presente. In: BRUNI, José Carlos, MENNABARRETO, Luiz, MARQUES Nelson (orgs.). Decifrando o tempo presente. São Paulo (SP): Editora UNESP, 2007, p. 11-22.

CAFRUNI, A. M. S. Autoecologia de ruppia marítima no estuário da Lagoa dos Patos. 1983. 63 f. Dissertação (Mestrado em Oceanografia Biológica) - Departamento de Oceanografia, Fundação Universidade do Rio Grande, Rio Grande, 1983.

CALLIARI, L. J. Aspectos sedimentológicos e ambientais da região sul da Lagoa dos Patos. 1980. Dissertação (Mestrado em Geociências) - Universidade Federal do Rio Grande do Sul, 1980.

CALVENTE, M. C. M. H. No território do azul marinho: a busca do espaço caiçara. 1993. Dissertação (Mestrado em Geografia) - Faculdade de Filosofia, Letras e Ciências Humanas, Universidade de São Paulo, São Paulo, 1993.

CAMPOS, M. D. Etnociência ou etnografia de saberes, técnicas e práticas. In: AMOROZO, M. C., MING, L. C., SILVA, S. M. P. (eds.). Métodos de coleta e análise de dados em etnobiologia, etnoecologia e disciplinas correlatas. Rio Claro: Ed. Unesp, 2002, p. 47-92. 
CARDOSO, E. S. Pescadores artesanais: natureza, território, movimento social. 2001. Tese (Doutorado em Geografia física) - Faculdade de Filosofia, Letras e Ciências Humanas, Universidade de São Paulo, São Paulo, 2001.

CHAREST, P. Contraintes ecologiques et pécheries sédentaries sur la base cotenord du Golfe Saint Laurent. Antropologies et Societés, vol. 5, nº 1, p. 29-56, 1981.

CARLOS, A. F. A. Espaço-tempo na metrópole: a fragmentação da vida cotidiana. São Paulo: Ed. Contexto, 2001, 368 p.

CARRIER, J. G., CARRIER, A. H. Marine tenure and economic reward on Ponam Island, Manus Province. In: CORDELL, J. (ed.). A sea of small boats. Cambridge (USA): Cultural Survival, 1989, p. 94-120.

CASTELlO, J. P., MÖLlER, O. O. On the oceanographic conditions in the Rio Grande do Sul state. Atlântica, Rio Grande (RS), vol. 2, nº 2, p. 25-110, 1977.

CERTEAU, M. A invenção do cotidiano. Tradução de Ephraim Ferreira Alves. Petrópolis (RJ): Ed. Vozes, 1996. 351 p. Original em francês.

CHAO, L. N., PEREIRA, L. E., VIEIRA, J. P., BEMVENUTI, M. A., CUNHA, L. P. R. Relação preliminar dos peixes estuarinos e marinhos da Lagoa dos Patos e região costeira adjacente, Rio Grande do Sul, Brasil. Atlântica, Rio Grande (RS), vol. 5, $\mathrm{n}^{\mathrm{o}}$ 1, p. $65-75,1982$.

CHESNEAUX, J. Modernidade-Mundo. Petrópolis (RJ): Editora Vozes, 1989.

CIOTTI, A. M., ODEBRECHT, C., FILLMANN, G., MÖLLER, O. O. Freshwater outflow and subtropical convergence influence on phytoplankton biomass on the southern Brazilian continental shelf. Cont Shelf Res, vol. 15, n 14, p. 1737-1756, 1995.

COELHO JÚNIOR, C., SCHAEFFER-NOVELLI, Y. S. Considerações teóricas e práticas sobre o impacto da carcinocultura nos ecossistemas costeiros, com ênfase no ecossistema de manguezal. (compact. disc.). In: CONFERENCIA INTERNACIONAL MANGROVE; SUSTENTABILIDADE DE ESTUÁRIOS E MANGUEZAIS: DESAFIOS E PERSPECTIVAS, Recife, 2000. Anais. Recife, UFRPE, 2000.

CORDELL, J. The lunar-tide fishing cycle in northeastern Brazil. Ethnology, vol. 13, p. 378-92, 1974. 
Locally managed sea territories in brasilian coastal fishing. In: FAO CONFERENCE ON COASTAL LAGOON FISHERIES, 1983. Locally managed sea territories in brasilian coastal fishing. Roma, september, 1983.

. Introduction: sea tenure. In: CORDELL, John (ed.). A sea of small boats. Cambridge (USA): Cultural Survival, 1989, p. 1-32.

- Marginalidade social e apropriação territorial marítima na Bahia. In: DIEGUES, A. C, MOREIRA, A. C (orgs.). Espaço e recursos naturais de uso comum. São Paulo: NUPAUB/USP, 2001, p. 139-162.

COSTA, C. S. B. Plantas e marismas e terras alagáveis. In: SEELIGER, U.; ODEBRECHT, C., CASTELLO, J. P. (eds). Os ecossistemas costeiro e marinho dos extremo sul do Brasil. Rio Grande: Ecoscientia, 1998, p. 25-29.

Costa, C. S. B., SEEliger, U., OliveirA, C. P. L., MAZO, A. M. M. Distribuição, funções e valores das marismas e pradarias submersas no estuário da Lagoa dos Patos (RS, Brasil). Atlântica, Rio Grande, vol. 19, p. 67-85, 1997.

COSTA, J. Navegadores da Lagoa dos Patos: a saga náutica de São Lourenço do Sul. São Lourenço do Sul (RS): Ed. Hofstätter, 1999.

COSTA, R. N. L. T. R. Pensar o mar para poder pescar: o espaço da pesca na baía de Sepetiva, RJ. 1992. Dissertação (Mestrado em Geografia) - Programa de Pós-graduação em Geografia, Universidade Federal do Rio de Janeiro, Rio de Janeiro, 1992.

CUNHA, L. H. Entre o mar e a terra: tempo e espaço em Barra da Lagoa. 1987. Dissertação (Mestrado em Ciências Sociais) - Programa de Pós-graduação em Ciências Sociais, Pontifícia Universidade Católica de São Paulo, São Paulo, 1987.

. Ordens e desordens socioambientais: saberes tradicionais em dinâmicas pesqueiras da costa paranaense. 2007. Tese (Doutorado em Meio Ambiente e Desenvolvimento) - Programa de Pós-graduação em Meio Ambiente e desenvolvimento, Universidade Federal do Paraná (Université Paris 7 - Université Bourdeaux), Curitiba, 2007.

CUNHA, L. H., ROUGEULlE, M. Comunidades litorâneas e unidades de proteção ambiental: convivência e conflitos; estudo de caso 2: o caso de Guaraqueçaba (PR). São Paulo: NUPAUB - USP, 1989. (Série: estudos de caso).

DIEGUES, A. C. Pescadores, camponeses e trabalhadores do mar. São Paulo: Ed. Ática, 1983. 
. Etnoconservação da natureza: enfoques alternativos. In: Diegues, A. C (org.). Etnoconservação: novos rumos para a proteção da natureza nos trópicos. São Paulo: Ed. AnnaBlume/Nupaub/Hucitec, 2000, p. 01-46.

. O mito moderno da natureza intocada. São Paulo: Ed. Hucitec, 2004a.

- Pesca construindo sociedades: leituras em antropologia marítima e pesqueira. São Paulo: Ed. Hucitec, 2004 b.

DIEGUES, A. C., ARRUDA, R. S. V. Saberes tradicionais e biodiversidade no Brasil. Brasília: Ministério do Meio Ambiente - MMA; São Paulo: USP, 2001.

DIEGUES, A. C., MOREIRA, A. C. Apresentação. In: DIEGUES, A. C., MOREIRA, A. C (org). Espaços e recursos naturais de uso comum. São Paulo: Nupaub - USP, 2001, p. 9-17.

D'INCAO, F. Pesca e biologia de Penaeus paulensis na Lagoa dos Patos, RS. Atlântica, Rio Grande (RS), vol. 13, nº 1, p. 159-169, 1991.

DIOGO, H. R. L., FIGUEIRA, L. D., GOMES, M. A. O. Plano de compensação da atividade pesqueira no Bloco BM-Cal-4: subsidios para a gestão compartilhada das pescarias artesanais no Baixo-Sul. Salvador (BA): Soma Desenvolvimento e Meio Ambiente, 2008. 251 p. Relatório Analítico.

DURHAM, E. R. A dinâmica da cultura. São Paulo: Ed. CosacNaify, 2004, 477p.

ELÍADE, M. O sagrado e o profano. São Paulo: Ed. Martins Fontes, 1992. . Mito e Realidade. $6^{\text {a }}$ ed. São Paulo: Ed. Perspectiva, 2004.

ELIAS, N. Sobre o tempo. Tradução de Vera Ribeiro. Rio de Janeiro (RJ): Jorge Zahar Ed., 1998.

EVANS-PRITCHARD, E. E. Os Nuer: uma descrição do modo de subsistência e das instituições políticas de um povo nilota. São Paulo: Ed. Perspectiva, 2007, 278 p.

FISHER, L. G., PEREIRA L. E. D., VIEIRA J. P. Peixes estuarinos e costeiros. Rio Grande: Ed. Ecoscientia, 2004, 127p. (Série Biodiversidade do Atlântico Sudoeste, 1). 
FOLKE, C, CARPENTER, S, WALKER, B, SHEFFER, M, ELMQVIST, T, GUNDERSON, L, HOLLING, CS. Regime shifts, resilience and biodiversity in ecosystem management. Annu. Rev. Ecol. Syst., 2004, vol. 35, p. 557-81.

FORMAN, S. The raft fishermen: tradition \& change in the brasilian peasant economy. EUA: Indiana University Press, 1970, 158 p.

FRAKE, C. O. The ethnographic study of cognitive systems. In: GLADWIN, T, STURVETANT, W (eds.). Anthropology and human behavior. Washington: Anthropological Society of Washington, 1962, p. 72-85.

FRAXE, T. J. P. Homens anfibios: etnografia de um campesinato das águas. São Paulo: Annablume: Fortaleza: Secretaria de Cultura e Desporto do Governo do Estado do Ceará, 2000, p. 192.

FREITAS, S. E. Arqueologia da Ilha dos Marinheiros, Rio Grande, Rio Grande do Sul, Brasil. 2003. 86 f. Monografia (Graduação em História) - Departamento de Biblioteconomia e História, Fundação Universidade Federal do Rio Grande, Rio Grande, 2003.

GAGNEBIN, J. M. História e narração em Walter Benjamin. São Paulo (SP): Editora Perspectiva, 2004, $114 \mathrm{p}$.

GAN, M. A. Ciclogênese e ciclones sobre a América do Sul. Tese (Doutorado em Ciências Atmosféricas), Instituto Nacional de Pesquisas Espaciais, INPE, São José dos Campos, 1992.

GARCIA, C. A. E. Características hidrográficas. In: SEELIGER, U; ODEBRECHT, C., CASTELLO, J. P. (eds). Os ecossistemas costeiro e marinho dos extremo sul do Brasil. Rio Grande: Ecoscientia, 1998, p. 18-21.

GARDET, L. Concepções muçulmanas sobre o tempo e a história. In: UNESCO. As culturas e o tempo. Tradução de Gentil Titton, Orlando dos Reis, Ephraim Ferreira Alves. São Paulo: Vozes: EDUSP, 1975, p. 229-62. Título original: Les cultures et le temps.

GEERTZ, C. Local knowledge. New York: Basic Books Inc, 1983.

. A interpretação das culturas. Rio de Janeiro: LTC editora, 1989. 
GERALDI, R. M. Características estruturais da assembléia de invertebrados bentônicos em fundos vegetados e não vegetados numa enseada estuarina da Lagoa dos Patos. Dissertação (Mestrado em Oceanografia Biológica) - Departamento de Oceanografia, Fundação Universidade do Rio Grande, Rio Grande, 1997.

GIDDENS, A. As consequências da modernidade. São Paulo: Editora UNESP, 1991, 177 p. (Biblioteca básica).

GIORDANO, P. B. Modelagem hidrodinâmica do Saco do Arraial, estuário da Lagoa dos Patos, RS. 2008. 100 f. Dissertação (Mestrado em Oceanografia Física, Química e Geológica) - Departamento de Oceanografia, Fundação Universidade do Rio Grande, 2008.

GIORDANO, P. B.; MARQUES, W. C.; MONTEIRO, I. O.; FERNANDES, E. H. Hidrodinâmica 3D das enseadas rasas do estuário da Lagoa dos Patos a partir da modelagem numérica. In: OMARSAT: SEMINÁRIO SOBRE ONDAS E MARÉS, ENGENHARIA OCEÂNICA E OCEANOGRAFIA POR SATÉLITE, 5, 2005, Arraial do Cabo. ResumosI... Arraial do Cabo: OmarSat, 2005.

. Influência da descarga fluvial na circulação das áreas rasas do estuário da Lagoa dos Patos (RS). In: OMARSAT: SEMINÁRIO SOBRE ONDAS E MARÉS, ENGENHARIA OCEÂNICA E OCEANOGRAFIA POR SATÉLITE, 6, 2007, Arraial do Cabo. Resumos VII... Arraial do Cabo: OmarSat, 2007.

GOMEZ-POMPA, A, KAUS, A. Domesticando o mito da natureza selvagem. In Diegues, AC (org.). Etnoconservação: novos rumos para a proteção da natureza nos trópicos. São Paulo: Ed. AnnaBlume/Nupaub/Hucitec, 2000, p. 125-148.

GOUREVITCH, A. Y. O tempo como problema de história cultural. In: UNESCO. As culturas e o tempo. Tradução de Gentil Titton, Orlando dos Reis, Ephraim Ferreira Alves. São Paulo: Vozes: EDUSP, 1975, p. 263-83. Título original: Les cultures et le temps.

GUIMARÃES, A. Z. Desvendando máscaras sociais. Rio de Janeiro: Edições Francisco, 1980.

GUNDERSON, L. Resilience, flexibility and adaptative management - antidotes for spurious certitude? Conservation Ecology, 1999, n 1, vol. 3, artigo 7 [online] URL: http://www.consecol.org/vol3/iss1/art7.

HAESBAERT, R. O mito da desterritorialização: do "fim dos territórios" à multiterritorialidade. $2^{\mathrm{a}}$ ed. Rio de Janeiro: Bertrand Brasil, 2006, 400p. 
HAIMOVICI, M., VASCONCELlOS, M., KALIKOSKI, D. C., ABDALLAH, P., CASTELlO, J. P., HELLEMBRANDT, D. Diagnóstico da pesca no litoral do estado do Rio Grande do Sul. In: A pesca marinha e estuarina do Brasil do inicio do século XXI: recursos, tecnologias, aspectos socioeconômicos e institucionais. ISAAC, V. J., MARTINS, A. S., HAIMOVICI, M., ANDRIGUETTO, J. M. (Orgs.). Belém (PA): Universidade Federal do Pará, 2006, 188p.

HALBWACHS, M. A memória coletiva. São Paulo (SP): Centauro Editora, 2006, 224 p.

HERZ, R. Circulação das águas de superficie da Lagoa dos Patos. 1977. Tese (Doutorado em Geografia) - Faculdade de Filosofia, Letras e Ciências Humanas, Universidade de São Paulo, São Paulo, 1977.

HOUAISS, A, VILlEN, M. S. Dicionário Houaiss de Língua Portuguesa. Rio de Janeiro (RJ): Editora Objetiva LTDA, 2004.

IBGE. Sinopse preliminar do senso demográfico 2000. Rio Grande: Instituto Brasileiro de Geografia e Estatística, 2000.

IHERING, H. V. A Lagoa dos Patos do séc. XIX. Rio Grande: Ed. Ecoscientia, 2003.

IWAQUIRI, S., MANTJORO, E. Traditional Marine Tenure in Indonésia - A study in Sangihe Islands. Bull. Kagoshima/Pref. College, vol. 43, p. 1-23, 1992.

JOHANNES, R. E. Traditional law of the sea of the Micronesia. Micronesia, vol. 13, 121-127, 1977.

. Traditional marine conservation methods in Oceania and their demise. Annual Review of Ecology and Systematics, vol. 9, 349-64, 1978.

KAGAME, A. Apercepção empírica do tempo e concepção da história no pensamento Bantu. In: UNESCO. As culturas e o tempo. Tradução de Gentil Titton, Orlando dos Reis, Ephraim Ferreira Alves. São Paulo: Vozes: EDUSP, 1975, p. 102-35. Título original: Les cultures et le temps.

KALIKOSKI, D. C. The forum of Patos Lagoon: an analisys of co-management arrangement for conservation of coastal resources in the southern of Brazil. Thesis (Doctor of Philosophy) - Program of Resource Management and Environmental Studies, University of British Columbia, Columbia, 2002. 
KALIKOSKI, D. C., VASCONCELLOS, M., LAVKULICH, L. Fitting institutions to ecosystems: the case of artisanal fisheries management in the estuary of Patos Lagoon. Marine Policy, vol. 26, p. 179-96, 2002.

KALIKOSKI, D. C., VASCONCELLOS, M. Fisheries knowledge role in the management of artisanal fisheries in the estuary of Patos Lagoon, southern Brazil. In: HAGGAN, N., NEIS, B., BAIRD, I. G. (eds.). Fisheries knowledge in fisheries management. Indigenous, artisanal \& industrial. Oxford (UK): Blackwell Science, 2005.

. The role of fisheries knowledge in the co-management of small-scale fisheries in the estuary of Patos Lagoon, southern Brazil. In: UNESCO. Fishers' knowledge in fisheries science and management. Oxford (UK): Blackwell science, 2006, p. 287-310.

KALIKOSKI, D. C., ROCHA, R. D., VASCONCELLOS, M. Importância do conhecimento ecológico tradicional na gestão da pesca artesanal no estuário da Lagoa dos Patos, extremos sul do Brasil. Revista Ambiente \& Educação. Rio Grande: Editora da FURG, in press.

KALIKOSKI, D. C., PINTO DA SILVA, P. Avanços e desafios na implementação de gestão compartilhada no Brasil: lições comparativas do fórum da Lagoa dos Patos (RS) e da Resex Marinha do Arraial do Cabo (RJ). In press.

KJERFVE, B. Comparative oceanography of coastal lagoons. In: Wolfe, D. A. (ed.). Estuarine Variability, New York: Academic Press, p. 63-81, 1986.

KLEIN, A. H. F. Clima regional. In: SEELIGER, U; ODEBRECHT, C., CASTELLO, JP. (eds). Os ecossistemas costeiro e marinho dos extremo sul do Brasil. Rio Grande: Ecoscientia, 1998, p. 5-7.

KOUSKY, V. E., CAVAlCANTI, I. F. A., Eventos de Oscilação Sul - El Niño: características, evolução e anomalias de precipitação. Ciência e Cultura, vol. 36, n 11 , p. 1888-99, 1984.

LABERGE, J. As naturezas do pescador. In: II Encontro de Ciências sociais e o mar, 1988, p. 236-258.

LEFF, E. Saber ambiental: sustentabilidade, racionalidade, complexidade, poder. Petrópolis: Vozes, 2001, 494p. 
LE GOFF, J. História e Memória. Campinas (SP): Editora da UNICAMP, 2003, 541 p.

LEITE, T. M. Digressões em torno do conceito tempo - a representação do presente. In: BRUNI, José Carlos, MENNA-BARRETO, Luiz, MARQUES Nelson (orgs.). Decifrando o tempo presente. São Paulo (SP): Editora UNESP, 2007, p. 107-26.

LEVY-STRAUSS, L. O pensamento selvagem. São Paulo: Ed. Nacional, 1976, 330p.

LONGHURST, A, SATHYENDRANATH, S, PLATT, T, CAVERHILL, C. An estimate of global primary prodution in the ocean from satellite radiometer data. $J$ Plankt Res, vol. 17, $\mathrm{n}^{\mathrm{o}}$ 6, p. 1245-1271, 1995.

MAESTRI, M. J. Quilombos e quilombolas em terras gaúchas. Porto Alegre: Escola Superior São Lourenço dos Brindes, 1979 apud FREITAS, Sabrina Escobar. Arqueologia da Ilha dos Marinheiros, Rio Grande, Rio Grande do Sul, Brasil. 2003. 86 f. Monografia (Graduação em História) - Departamento de Biblioteconomia e História, Fundação Universidade Federal do Rio Grande, Rio Grande, 2003.

MALDONADO, S. C. No mar: conhecimento e produção. In: DIEGUES, Antônio Carlos Sant'Ana. Ciências sociais e o mar no Brasil, São Paulo: IOUSP/FFORD/UICN, 1988 , p.259-265.

. Mestres \& Mares: espaço e indivisão na pesca marítima. São Paulo: ANNABLUME, 1993, 194 p. (Selo universidade, 7).

MARANHÃO, T. P. Náutica e classificação ictiológica em Icaraí, Ceará: um estudo em antropologia cognitiva. 1975. 166 f. Dissertação (Mestrado em Antropologia Social), Universidade de Brasília, Brasília, 1975.

MARQUES, J. G. W. Aspectos ecológicos na etnoictiologia dos pescadores do complexo estuarino-lagunar Mundaú-Manguaba, AL. 1991. 297 f. Tese (Doutorado em Ciências) - Pós-graduação em Ecologia, Universidade Estadual de Campinas, Campinas, 1991.

Pescando pescadores: Ciência e etnociência em uma perspectiva ecológica. São Paulo: Núcleo de Apoio à Pesquisa sobre Populações Humanas e Áreas Húmidas Brasileiras, USP, 2001, 258p.

MARQUES, L. A. B. O pescador artesanal do sul. Rio de Janeiro: MEC/SEAC/FUNARTE/Instituto Nacional do Folclore, 1980, 75p. 
MARQUES, W. M. Estrutura da comunidade de peixes em enseadas protegidas do estuário da Lagoa dos Patos (RS - Brasil). 1994. 58 f. Monografia (Graduação em Oceanologia) - Departamento de Oceanografia, Fundação Universidade do Rio Grande, Rio Grande, 1994.

MARTINS, S. F. Cidade do Rio Grande: industrialização e urbanidade (1873-1990). Rio Grande (RS): Editora da FURG, 2006, 234p.

MAUSS, M. Sociologia e antropologia. Tradução de Paulo Neves. São Paulo: Cosac Naify, 2003, 536 p. Título original: Sociologie et anthropologie.

MENESTRINO, E. H. G., MENTZ RIBEIRO, P. A. Vieira, Charrua e Minuano: um mesmo grupo? In: ALVES, Francisco das Neves, TORRES, Luis Henrique (orgs.). $A$ cidade do Rio Grande: estudos históricos. Rio Grande: ed. FURG/SMEC, 1995, 7-21p.

MILlER, F. S. Pescadores e coletoras de Patané/Camocim: aspectos da adaptação humana aos Manguezais do Rio Grande do Norte. 2005. 190 f. Tese (Doutorado em Ciências Sociais) - Programa de Estudos Pós-graduados em Ciências Sociais, Pontifícia Universidade Católica de São Paulo, São Paulo, 2005.

MINISTÉRIO DA AGRICULTURA/GRUPO EXECUTIVO DE ESTATÍSTICA, ANÁLISE E ESTUDOS ECONÔMICOS. O pescado na Guanabara e a atividade pesqueira nacional. Guanabara, 1968.

MINISTÉRIO DO MEIO AMBIENTE, SECRETARIA ESPECIAL DE AQUICULTURA E PESCA. Instrução normativa conjunta, $\mathrm{n}^{\circ} 3,9$ de fevereiro de 2004. Brasília: MMA/SEAP, 2004, 8p.

MIRANDA, L. B., CASTRO, B. M., KJERFVE, B. Principios de oceanografia física de estuários. São Paulo: EDUSP, 2002.

MÖOLER, O. O., CASTAING, P. Hydrographical characteristics of the estuarine area of Patos Lagoon $\left(30^{\circ} \mathrm{S}\right.$, Brazil). In: PERILlO, G. M. E., PICCOLO, M. C., PINOQUIVIRA, M. (Eds.). Estuaries of South America: their geomorphology and dynamics. Berlim (Germany): Springer, 1999, p. 83-100.

MÖOLER, O. O., CASTAING, P., SALOMON, J. C., LAZURE, P. The influence of local and non-local forcing effects on the subtidal circulation of Patos Lagoon. Estuaries, vol. 24, nº 2, p. 297-311, april 2001. 
MOREIRA, T. C. Os conhecimentos tradicionais associados à biodiversidade no Brasil e a sua abordagem jurídica no limiar do século biotecnológico. 2003. Dissertação (Mestrado em Ciência Ambiental) - Programa de Pós-graduação em Ciência Ambiental, Universidade de São Paulo, São Paulo, 2003.

NIENCHESKI, L. F., BAUNGARTEN, M. G. Química ambiental. In: SEELIGER, U; ODEBRECHT, C., CASTELLO, J. P. (eds). Os ecossistemas costeiro e marinho dos extremo sul do Brasil. Rio Grande: Ecoscientia, 1998, p. 21-24.

NIETSCHMANN, B. Traditional sea territories resources and rights in Torres Strait. In: CORDELL, J. (ed.). A sea of small boats. Cambridge (USA): Cultural Survival, 1989, p. 60-92.

NOBRE, C. A., CAVALCANTI, M. A. G., NOBRE, P, KAYANO, M. T., RAO, V. B., BONATTI, J. P., SATYAMURTI, P, UVO, C. B., COHEN, J. C. Aspectos da climatologia dinâmica do Brasil. Climanálise número especial, 1986.

OLIVEIRA, A. R. Bioecologia do siri-azul Callinectes sapidus Rathbun, 1896, na região estuarina da Lagoa dos Patos, RS, Brasil. 2005, 172 f. Tese (Doutorado em Oceanografia Biológica) - Departamento de Oceanografia Biológica, Fundação Universidade Federal do Rio Grande, Rio Grande, 2005.

OLIVEIRA JÚNIOR, G. A. O encanto das águas: a relação dos Tremembé com a natureza. 2003. Dissertação (Mestrado em Ciências Sociais) - Programa de Estudos Pós-graduados, Pontifícia Universidade Católica de São Paulo, São Paulo, 2003.

OLSSON, P., FOLKE, C. Adaptative comanagement for building resilience in socialecological systems. Environmental management, 2004, vol. 34, nº 1, p. 75-90.

PAIVA, R. Subjetividade e imagem: a literatura como horizonte da filosofia em Henri Bergson. São Paulo: Associação Editorial Humanitas, Fapesp, 2005, 441 p.

PANIKKAR, R. Tempo e história na tradição da índia. In: UNESCO. As culturas e o tempo. Tradução de Gentil Titton, Orlando dos Reis, Ephraim Ferreira Alves. São Paulo: Vozes: EDUSP, 1975, p.73-101. Título original: Les cultures et le temps.

PASQUOTTO, V. F. Pesca artesanal no Rio Grande do Sul: os pescadores de São Lourenço do Sul e suas estratégias de reprodução social. 2005. 164 f. Dissertação (Mestrado em Desenvolvimento Rural) - Faculdade de Ciências Econômicas, Universidade Federal do Rio Grande do Sul, Porto Alegre, 2005. 
PIETRAFESA DE GODOI, E. O trabalho da memória: cotidiano e história no sertão do Piauí. Campinas (SP): Editora da Unicamp, 1999.

PIETTRE, B. Filosofia e ciência do tempo. Tradução de Maria Antônia Pires de C. Figueiredo. Bauru (SP): EDUSC, 1997, 224 p. (Coleção Humus).

POSEY, D. A. Introdução-Etnobiologia: teoria e prática. In: RIBEIRO D. (ed.). Suma etnológica brasileira. Petrópolis: Ed. Vozes, 1986.

. A ciência dos Mëbëngôkre: alternativas contra a destruição. Belém: Museu Paraense Emílio Goeldi, 1987.

. Interpretando e usando a "realidade" dos conceitos indígenas: o que é preciso aprender dos nativos?. In: DIEGUES, A. C, MOREIRA, A. C (orgs.). Espaço e recursos naturais de uso comum. São Paulo: NUPAUB/USP, 2001, p. 279-294.

POSEY, D. A.; ELISABELISK, E. Conceito de animais e seus espíritos em relação a doenças e curas entre os índios Kayapó da aldeia Gorotise, Pará. Boletim do Museu Paraense, Belém: vol. 7, n.1, p. 21-37, julho de 1991. (Série Antropologia).

PREFEITURA MUNICIPAL DE RIO GRANDE. Proposta de criação de Diretoria de Agricultura, CXXII, 23 de dezembro de 1936. Rio Grande: Diretoria de Administração da Prefeitura Municipal. Acervo de documentos da Prefeitura de Rio Grande. 3 p.

QUEIROZ, M. I. P. Relatos orais: do "indizível” ao "dizível”. In: VON SIMSON, O. M. Experimentos com histórias de vida. São Paulo: Vértice Editora, 1988, p. 14-43.

RAFFESTIN, C. Por uma geografia do poder. Tradução de Maria Cecília França. São Paulo: Ed. Ática, 1993, 269 p. Título original: pour une geographie du pouvoir.

RAMALHO, C. W. N. “Ah, esse povo do mar!”: um estudo sobre trabalho e pertencimento na pesca artesanal pernambucana. São Paulo: Polis: Campinas (SP): CERES, 2006. 175 p.

RAPPAPORT, R. A. Natureza, cultura e antropologia ecológica. In: SHAPIRO, H. Homem, cultura e sociedade. São Paulo: Ed. Martins Fontes, 1984, pp. 251-282.

REHFELD, W. T. Tempo e religião: a experiência do homem bíblico. São Paulo: Ed. Perspectiva: EDUSP, 1988, 176 p. 
RIBEIRO, B. G. Os índios das águas pretas: modo de produção e equipamento produtivo. São Paulo: Companhia das Letras: Edusp, 1995, 270 p.

RICOEUR, P. Introdução. In: UNESCO. As culturas e o tempo. Tradução de Gentil Titton, Orlando dos Reis, Ephraim Ferreira Alves. São Paulo: Vozes: EDUSP, 1975, p. 15-39. Título original: Les cultures et le temps.

RIO GRANDE DO SUL. Relatório sobre a pesca, 1975. Porto Alegre: Assembléia Legislativa do Rio Grande do Sul. Relatório da Comissão especial sobre pesca, 1975 apud PASQUOTTO, V. F. Pesca artesanal no Rio Grande do Sul: os pescadores de São Lourenço do Sul e suas estratégias de reprodução social. 2005. 164 f. Dissertação (Mestrado em Desenvolvimento Rural) - Faculdade de Ciências Econômicas, Universidade Federal do Rio Grande do Sul, Porto Alegre, 2005.

. Remetência de mudas de videiras para a Cidade do Rio Grande, n. 509, 23 de julho de 1930a. Caxias do Sul: Estação Experimental de Viticultura e Enologia de Caxias. Diretoria de Agricultura, Indústria e Comércio da Secretaria de Estado dos negócios das Obras Públicas do Estado do Rio Grande do Sul. Acervo de documentos da prefeitura de Rio Grande. 2 p.

. Congratulações pelo propósito de criação de uma Inspetoria Agrícola Municipal, n. 655, 6 de outubro de 1930b. Caxias do Sul: Estação Experimental de Viticultura e Enologia de Caxias. Diretoria de Agricultura, Indústria e Comércio da Secretaria de Estado dos Negócios das Obras Públicas do Estado do Rio Grande do Sul. Acervo de documentos da Prefeitura de Rio Grande. 2 p.

RODRIGUES, M. A. Crescimento e ciclo de mudas de Callinectes sapidus (Rathbun, 1896) no estuário da Lagoa dos Patos. 2006. 83 f. Dissertação (Mestrado em Oceanografia Biológica) - Departamento de Oceanografia Biológica, Fundação Universidade do Rio Grande, Rio Grande, 2006.

RUDDLE, K. Systems of knowledge: dialogue, relationships and process. In: BEGOSSI, A, HENS, L (eds.). Environmnent, development and sustainability: a multidisciplinary approach to the theory and practice of sustainable development. Kluwer Academic Publishers, vol. 2, no 3-4, p. 277-304, 2000.

RUIVO, J. C. V. Contribuição para a história da Ilha dos Marinheiros. In: NEVES, Francisco, TORRES, Luiz Henrique. Tema de história do Rio Grande do Sul. Rio Grande: FURG, 1994, p. 147-162.

SAHLINS, M. Cultura e razão poética. Rio de Janeiro: Zahar, 1979. 
SAINT-HILAIRE, A. Viagem ao Rio Grande do Sul, 1820-1821. Belo Horizonte: Ed. Itatiaia; São Paulo: Edusp, 1974.

SCHARTZMANN, S. Florestas cercadas: lições do passado, propostas para o futuro. In Diegues, AC (org.). Etnoconservação: novos rumos para a proteção da natureza nos trópicos. São Paulo: Ed. AnnaBlume/Nupaub/Hucitec, 2000, p. 259-72.

SCHMIDT, M. L. S., MAHFOUD, M. Halbwachs: memória coletiva e experiência. Revista Psicologia USP. São Paulo, vol. 4, nº 1-2, p. 285-298, 1993.

SCHWARTZ, M., SCHWARTZ, C. G. Problems in participant observation. American journal of sociology, LX, jan. 1955.

SEELIGER, U. Fanerógamas marinhas submersas. In: SEELIGER, U; ODEBRECHT, C., CASTELlO, J. P. (eds). Os ecossistemas costeiro e marinho dos extremo sul do Brasil. Rio Grande (RS): Ecoscientia, 1998, p. 29-32.

SEELIGER, U., ODEBRECHT, C. Introdução e aspectos gerais. In: SEELIGER, U., ODEBRECHT, C., CASTELlO, J. P. (eds). Os ecossistemas costeiro e marinho dos extremo sul do Brasil. Rio Grande: Ecoscientia, 1998, p. 1-3.

SEIXAS, C. S., BERKES, F. Learning from fishers: local knowledge for management. In: VIEIRA, P. F. (org.). Conservação da diversidade biológic e cultural em zonas costeiras: enfoques e experiências na América Latina e no Caribe. Florianópolis (SC): APED, 2003, p. 332-71.

SILVA, C. N. Territorialidades e modo de vida de pescadores do rio Ituquara, Breves PA. 2006. Dissertação (Mestrado em Geografia) - Programa de Pós-graduação em Geografia, Universidade Federal do Pará, Belém, 2006.

SILVA, L. G. A faina, a festa e o rito: uma etnografia histórica sobre as gentes do mar (sécs. XVII ao XIX). Campinas (SP): Papirus, 2001, 256 p.

SILVANO, R. A. M., McCORD, P. F. L., LIMA, R. V., BEGOSSI, A. When does this fish spawn? Fishermen's local knowledge of migration and reroduction of brasilian costal fishes. Environ. Biol. Fish, vol. 76, p. 371-386, 2006.

SINGER, P. Desenvolvimento econômico e evolução urbana. 2. ed. São Paulo: Cia. Ed. Nacional, 1977. 
SINQUE, C., MUELBERT, J. H. Ictioplânton. In: SEELIGER, U.; ODEBRECHT, C., CASTELLO, J. P. (eds). Os ecossistemas costeiro e marinho dos extremo sul do Brasil. Rio Grande (RS): Ecoscientia, 1998, p. 56-60.

SOARES, M. N. Banco de dados geográfico socioeconômico da Ilha dos Marinheiros, Rio Grande, RS, Brasil. 2005. Monografia (Graduação em Geografia) - Departamento de Geociências, Fundação Universidade Federal do Rio Grande, Rio Grande (RS), 2005 .

SOUTO, F. J. B. A ciência que veio da lama: uma abordagem etnológica abrangente das relações ser humano/manguezal na comunidade pesqueira de Acupe, Santo Amaro, Bahia. 2004. 308f. Tese (Doutorado em Ecologia e Recursos Naturais) - Centro de Ciências Biológicas e da Saúde, Universidade Federal de São Carlos, São Carlos (SP), 2004.

SOUZA, M. A. A. Política e evolução da atividade pesqueira no Rio Grande do Sul: 1960 a 1997. 2001. 97 f. Dissertação (Mestrado em Economia Rural) - Faculdade de Ciências Econômicas, Universidade Federal do Rio Grande do Sul, Porto Alegre, 2001.

Pluriatividade entre os pescadores artesanais do estuário da Lagoa dos Patos no Rio Grande do Sul. In: CONGRESSO BRASILEIRO DE ECONOMIA E SOCIOLOGIA RURAL, 41. Anais... 2003, Juiz de Fora (MG).

SPRADLEY, J. P., McCURDY, D. W. The cultural experience. Ethnography in complex society. Chicago: Science Research Associate, 1972.

SUDEPE. Diagonóstico do setor pesqueiro no Rio Grande do Sul, Rio Grande: SUDEPE, 1988. (Relatório Técnico).

STEWARD, J. H. Theory of culture change: the methodology of multilinear evolution. Urbana: University of Illinois Press, 1955, 244 p.

THOMPSON, E. P. Costumes em comum. Revisão Técnica de Antônio Negro, Cristina Meneguello e Paulo Fontes. São Paulo: Companhia das Letras, 1998, 493 p. Título original: Customs in common.

THORNTON, R. J. Space, time and culture among the iraqw of Tanzania. New York: Academic Press, 1980.

TORRES, L. H. A fundação do Rio Grande na obra e Simão Pereira de Sá. In: ALVES, F. N., TORRES, L. H. (orgs.). A cidade do Rio Grande: estudos históricos. Rio Grande: ed. FURG/SMEC, 1995, p. 22-33. 
VIEIRA, J. P. Distribuição, abundância e alimentação dos jovens de Mugilidae no estuário da Lagoa dos Patos, e movimentos reprodutivos da "Tainha" (Mugil platanus Günder, 1880). 1985. 104 f. Dissertação (Mestre em Ciências) - Departamento de Oceanografia Biológica, Fundação Universidade de Rio Grande, Rio Grande, 1985.

Ecology of estuarine fish assemblages in Patos Lagoon, Brazil (32 $\left.{ }^{\circ}\right)$, and York River, USA $\left(37^{\circ} \mathrm{N}\right)$, with review of zoogeography of fishes in western Atlantic warm-temperate and tropical estuaries. 1991. $171 \mathrm{f}$. Thesis (Doctor of Philosophy) The Faculty of the School of Marine Science, The College of Willian and Mary, Virginia, 1991.

VIEIRA, J. P., CASTELlO, J. P., PEREIRA, L. E. Ictiofauna. In: SEELIGER, U; ODEBRECHT, C., CASTELlO, J. P. (eds). Os ecossistemas costeiro e marinho dos extremo sul do Brasil. Rio Grande: Ecoscientia, 1998, p. 60-68.

VIERTLER, R. B. Métodos antropológicos como ferramenta para estudos em etnobiologia e etnoecologia. In: AMOROZO, M. C, MING, L. C, SILVA, S. M. P.(eds.). Métodos de coleta e análise de dados em etnobiologia, etnoecologia e disciplinas correlatas. Rio Claro: Ed. Unesp, 2002, p. 11-30.

WEIL, S. A condição operária e outros estudos sobre a opressão. Tradução de Therezinha G. G. Langlada; seleção e apresentação de Ecléia Bosi. Rio de Janeiro (RJ): Ed. Paz e Terra, 1979, 439 p. Título original: La condition ouvrière...

WILSON, J. A., ACHESON, J. M., METCALFE, M., KLEBAN, P. Chaos, complexity an community management of fisheries. Marine Policy, vol. 18, $\mathrm{n}^{\mathrm{o}}$ 4, p. 291-305, 1994. 